I N T ER N ATIONAL MONETARY FUND

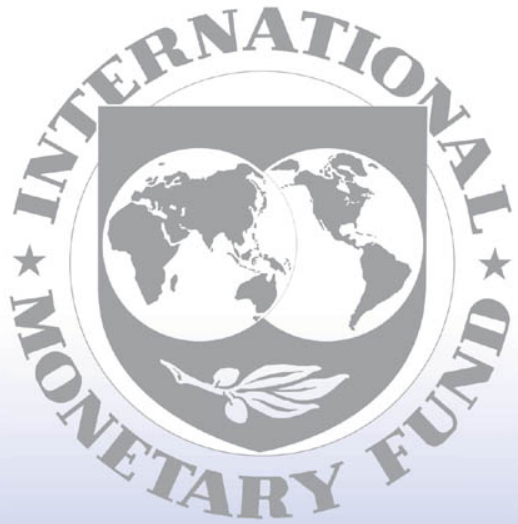

Staff

Country

Reports 


\title{
Mozambique: Sixth Review Under the Policy Support Instrument, Second Review Under the Arrangement Under the Exogenous Shocks Facility, and Request for a Three-Year Policy Support Instrument_-Staff Report; Staff Supplement; Press Release on the Executive Board Discussion; and Statement by the Executive Director for Mozambique.
}

In the context of the Sixth Review Under the Policy Support Instrument, Second Review Under the Arrangement Under the Exogenous Shocks Facility, and Request for a Three-Year Policy Support Instrument, the following documents have been released and are included in this package:

- $\quad$ The staff report for the Sixth Review Under the Policy Support Instrument, Second Review Under the Arrangement Under the Exogenous Shocks Facility, and Request for a Three-Year Policy Support Instrument, prepared by a staff team of the IMF, following discussions that ended on March 31, 2010, with the officials of Mozambique on economic developments and policies. Based on information available at the time of these discussions, the staff report was completed on May 27, 2010. The views expressed in the staff report are those of the staff team and do not necessarily reflect the views of the Executive Board of the IMF.

- A staff supplement on the joint IMF/World Bank debt sustainability analysis.

- A Press Release summarizing the views of the Executive Board as expressed during its June 14, 2010 discussion of the staff report that completed the request and/or review.

- $\quad$ A statement by the Executive Director for Mozambique.

The policy of publication of staff reports and other documents allows for the deletion of market-sensitive information.

\author{
Copies of this report are available to the public from \\ International Monetary Fund • Publication Services \\ $70019^{\text {th }}$ Street, N.W. • Washington, D.C. 20431 \\ Telephone: (202) 623-7430 • Telefax: (202) 623-7201 \\ E-mail: publications@imf.org Internet: http://www.imf.org
}

\section{International Monetary Fund Washington, D.C.}


INTERNATIONAL MONETARY FUND

REPUBLIC OF MOZAMBIQUE

\title{
Sixth Review Under the Policy Support Instrument, Second Review Under the Arrangement Under the Exogenous Shocks Facility, and Request for a Three-Year Policy Support Instrument
}

\author{
Prepared by the African Department \\ (In consultation with other departments) \\ Approved by Roger Nord and Dominique Desruelle
}

May 27, 2010

\begin{abstract}
- $\quad$ Discussions were held in Maputo, March 15-31. The mission team included Messrs. Mueller (head), Staines, Rosa, Crispolti (all AFR), Mr. Vitek (SPR), Mr. Fischer (resident representative), and Ms. Bosten and Mr. Wane (resident representative office). Messrs. Sulemane (OED), Pereira da Silva (Country Director, World Bank) and Nucifora (Senior Economist, World Bank) also participated in the discussions.

- $\quad$ The mission met with Minister of Finance Chang, Minister of Planning and Development Cuereneia, Bank of Mozambique (BM) Governor Gove, other senior government officials, and representatives of the private sector, civil society, and the donor community.

- A three-day high-level conference, organized jointly by the government, the Fund, and the Bank was held in Namaacha (southern Mozambique) to discuss strategies to sustainably and equitably raise economic growth and related policy options. Fund and Bank staff were invited to present and discuss the conference's conclusions in a meeting of the Council of Ministers on March 25 in Maputo, chaired by Prime Minister Ali. The conference also informed program discussions and facilitated the identification of priority areas for structural reforms and capacity building needs.

- $\quad$ The Executive Board approved the three-year PSI on June 18, 2007 and the one-year ESF arrangement on June 30, 2009. It concluded the fifth PSI review and the first ESF review on December 6, 2009.

- In the attached Letter of Intent and Memorandum of Economic and Financial Policies (MEFP), the authorities request completion of the final PSI/ESF reviews and approval of a successor three-year PSI.
\end{abstract}




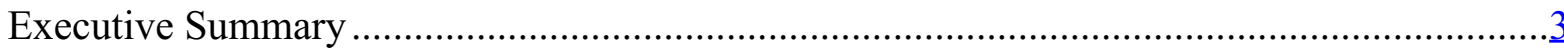

I. Exiting the Global Financial Crisis .............................................................................

II. A New PSI—Setting Policies for Sustained Growth ...........................................................

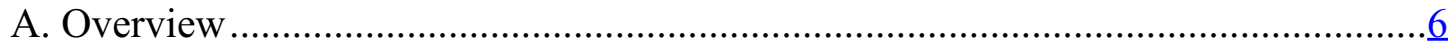

B. Achievements in Past Programs ........................................................................

C. Mozambique's Macroeconomic Challenges ……………....................................12

D. The Design of the New Program......................................................................15

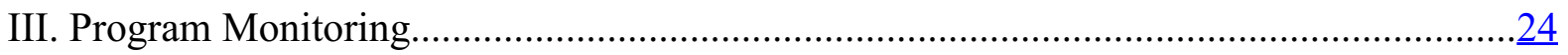

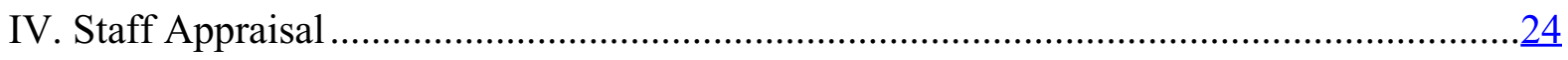

Tables

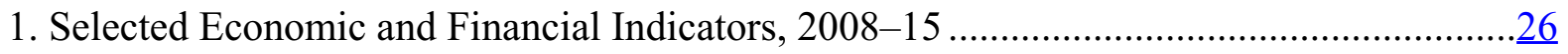

2. Government Finances, 2008-15 (MT Billions) ………...................................................27

3. Government Finances, 2008-15 (Percent of GDP) ……………………………….....

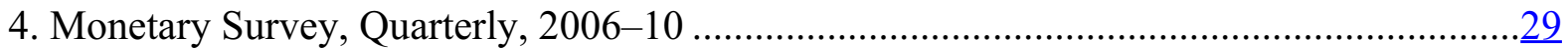

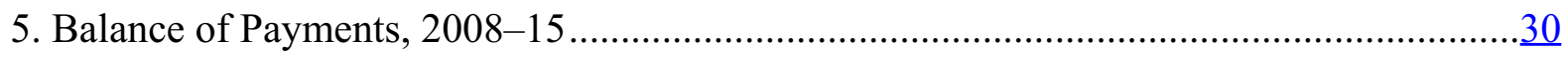

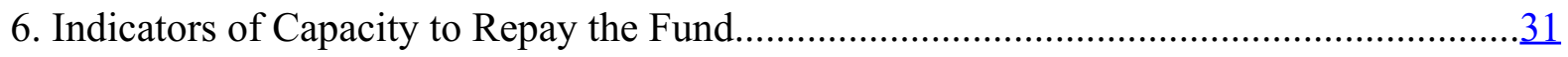

7. Financial Soundness Indicators for Banking Sector, 2001-09 ………..............................

8. Quantitative Assessment and Performance Criteria and Indicative Targets.........................

9. Structural Conditionality Under Current PSI/ESF, 2010 .................................................

Figures

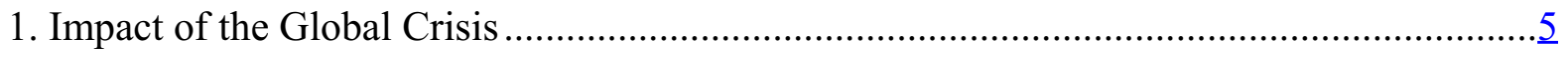

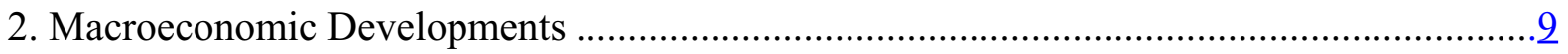

Boxes

1. Agreement on Resumption of Donor Aid .......................................................................

2. A Strong Track Record in Program Implementation Since 2004 ……………..................11

3. Namaacha Conference on Mozambique's Economic Challenges and Policy Options.........13

4. Empirical Evidence on the Determinants of Economic Growth.....................................14

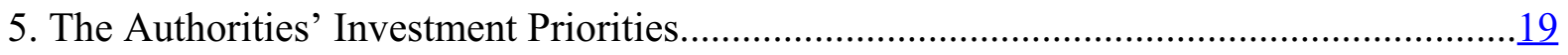

6. Enhancing Investment Planning and Debt Management ..................................................21

Appendices

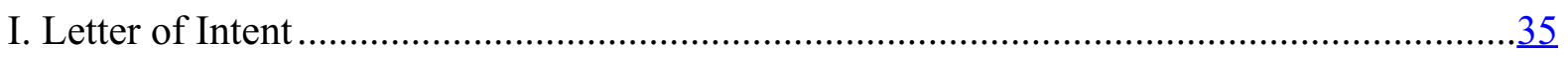

Attachment I. Memorandum of Economic and Financial Policies ........................................

Attachment II. Technical Memorandum of Understanding ...................................................51 


\section{EXECUTIVE SUMMARY}

The impact of the global crisis on Mozambique was limited. Economic activity remained buoyant in 2009, helped also by the authorities' easing of fiscal and monetary policies. The main transmission channels of the crisis were a drop in export receipts and private capital inflows, which the SDR allocation and ESF resources helped cushion. With the improved economic outlook for 2010, the authorities intend to unwind the fiscal and monetary stimuli.

The current PSI, which will expire in June, has served Mozambique well. It proved sufficiently flexible to allow the authorities to adjust their macroeconomic policies in response to two exogenous shocks: the fuel and food price surge and, more recently, the global crisis. The authorities showed commendable program ownership, with an overall strong implementation record and achievement of macroeconomic objectives. Nonetheless, difficulties remained in predicting the demand for cash in the face of rapidly expanding banking services in rural areas. This, coupled with last year's more accommodating monetary policy to help shore up the economy to the global crises, led to the nonobservance of the reserve money target for end-2009-for which the authorities request a waiver.

\section{Mozambique's economic challenges and the related policy options going forward remain daunting. The authorities aim to diversify the country's productive base and increase the role of the private sector, thereby creating employment opportunities and reducing poverty. Their focus in this regard is on expanding the transportation and electricity infrastructure networks, for which they consider tapping nonconcessional external resources. Staff analysis confirms Mozambique's relatively low capital abundance and investment rates, but suggests a cautious borrowing approach so as to preserve macroeconomic stability and debt sustainability. Other policies could be conducive to fostering private sector activity as well, including in particular efforts to create a more favorable business climate.}

\section{The successor PSI aims to support the authorities' twin objectives of accelerating economic development and maintaining macroeconomic stability. It envisages a limited and time-bound expansion of untied nonconcessional external borrowing and domestic financing to boost infrastructure investment while maintaining a prudent fiscal policy stance that would keep the primary domestic deficit broadly unchanged. Monetary policy will be sufficiently tight to keep domestic demand pressures in check while providing ample room for private sector credit expansion. The structural reform focus will be on improving the authorities' capacity for informed decision making, by promoting debt management, developing a borrowing strategy, and improving investment planning; and on continuing the ongoing reforms with respect to public financial management, tax policy and administration, the monetary policy framework, and financial sector supervision.}

Staff supports the authorities' request for waiver of the nonobservance of the endDecember 2009 assessment/performance criterion on reserve money, the completion of the final PSI/ESF program reviews, and approval of the successor PSI. 


\section{Exiting The GLOBAL Financial CRISIS}

1. Mozambique showed considerable resilience to the global crisis. Real GDP grew by $6 \frac{1}{3}$ percent in 2009 , more than expected, owing to stronger performance of the construction, energy, and financial sectors. Large declines occurred in export receipts and private capital inflows, but the impact on external reserves was mitigated by the SDR allocation and ESF resources (Figure 1).

\section{The government responded to the crisis by promptly easing}

macroeconomic policies. An accommodating monetary policy facilitated the substitution of foreign borrowing with a domestic credit expansion. Strong revenue performance has kept automatic stabilizers small, resulting in a lower-than-anticipated domestic primary deficit. Inflation has been subdued because of low commodity prices and the introduction of fuel price subsidies in May 2009, but some pick up occurred toward year-end owing to a rebound in international prices and the depreciating currency.

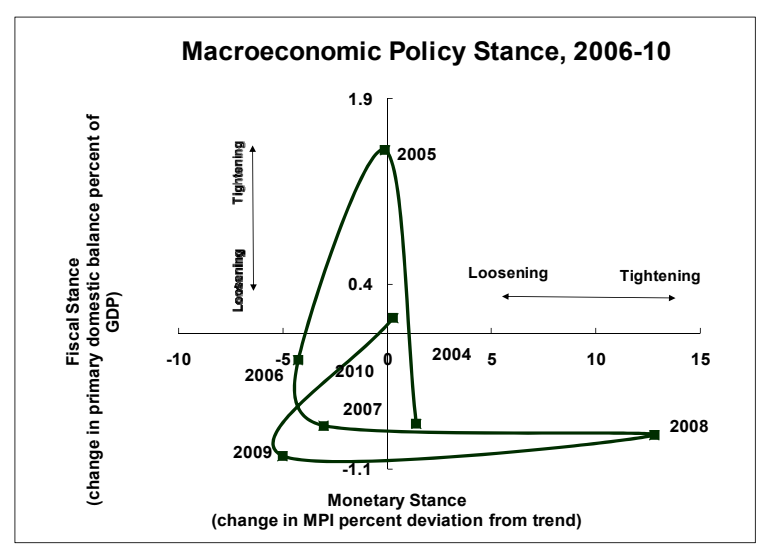

\section{The PSI provided an effective and flexible}

\section{framework to guide policies during the crisis, and program}

performance has been strong. All quantitative targets for end-December 2009 were met, except the one on reserve money. This target was missed because of the continued difficulties to predict the year-end surge in seasonal currency demand and the structural shift from an 'unbanked' to a 'banked' economy. ${ }^{1}$ In addition, the authorities deliberately eased monetary conditions more than expected to accommodate the substitution of foreign borrowing with domestic credit in a welcome effort to shore up economic activity. However, the BM is committed to restraining monetary growth in 2010. Structural reforms are on track as well; only the benchmark on the development of a financial sector contingency plan will be delayed by four months because of

\begin{tabular}{|c|c|c|}
\hline \multicolumn{3}{|c|}{ Mozambique: Quantitative Assessment and Performance Criteria and Indicative Targets } \\
\hline & \multicolumn{2}{|c|}{2009} \\
\hline & $\begin{array}{c}\text { End-Sept } \\
\text { Ind. targets } \\
\end{array}$ & $\begin{array}{c}\text { End-Dec } \\
\text { AC/PC }\end{array}$ \\
\hline \multicolumn{3}{|l|}{ Assessment/Performance Criteria for end-June/December } \\
\hline Net credit to the government (cumulative ceiling) & Met & Met \\
\hline Stock of reserve money (ceiling) & Not Met & Not Met \\
\hline Stock of net international reserves of the BM (floor, US\$ millions) & Met & Met \\
\hline $\begin{array}{l}\text { New nonconcessional external debt contracted or guaranteed by the central } \\
\text { government or the BM or State owned enterprises with maturity of one year or } \\
\text { more (ceiling, US\$ millions) }\end{array}$ & Met & Met \\
\hline Stock of short-term extemal public debt outstanding (ceiling) & Met & Met \\
\hline External payments arrears (ceiling) & Met & Met \\
\hline \multicolumn{3}{|l|}{ Indicative targets: } \\
\hline Government revenue (cumulative floor) & Met & Met \\
\hline
\end{tabular}
difficulties in securing World Bank funding for the exercise.

\footnotetext{
${ }^{1}$ More than half of Mozambique's 128 districts do not have a bank branch, although the country's four commercial banks have accelerated the expansion of their networks.
} 
Figure 1. Mozambique: Impact of the Global Crisis

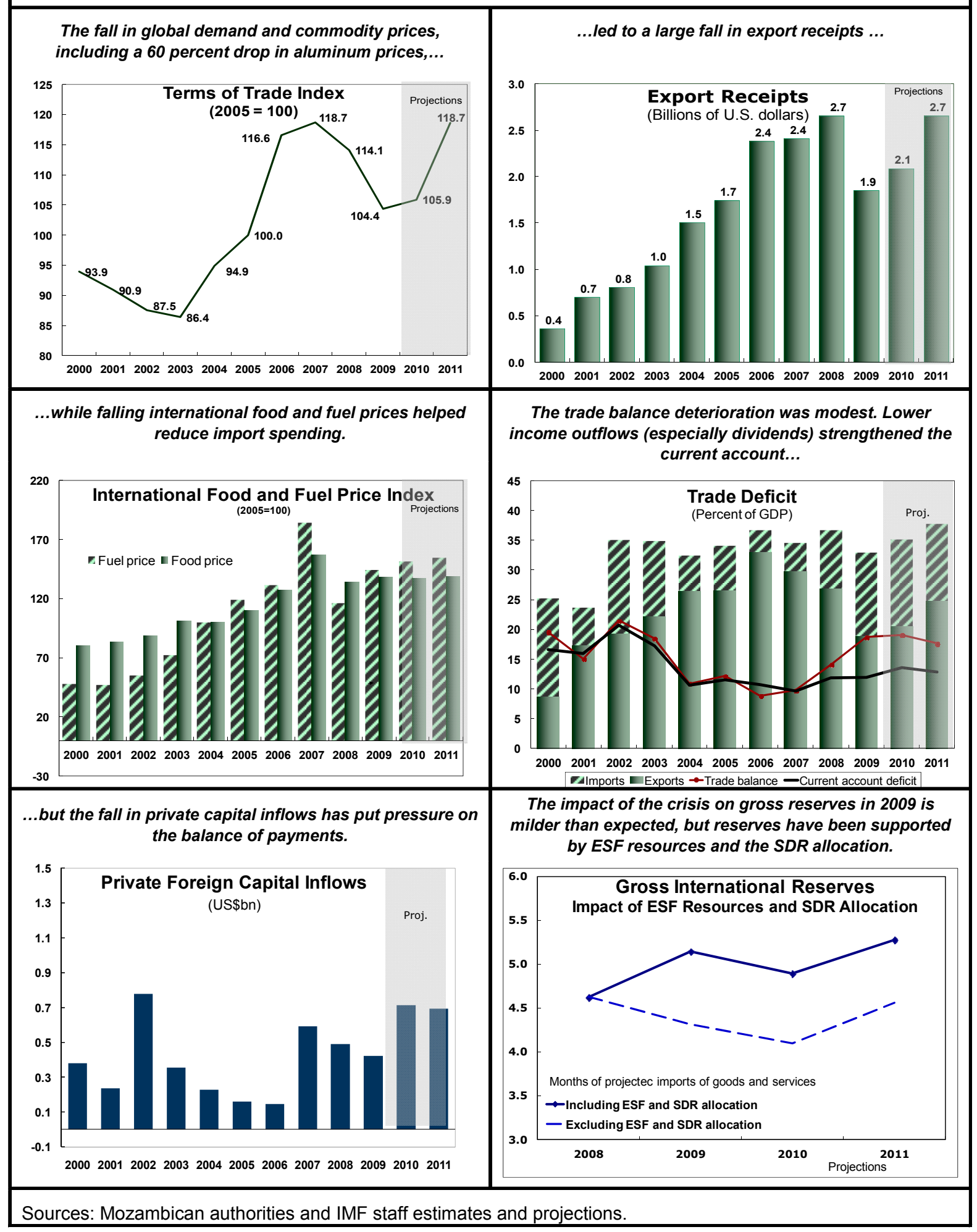


4. The economic outlook for $\mathbf{2 0 1 0}$ has improved. Growth could accelerate to $6 \frac{1}{2}$ percent in 2010 , led bynew megaprojects in the natural MEFP $97-8$ resources sector and stepped-up public investment. Inflation should remain in single digits, despite a temporary spike reflecting spillovers from the gradual removal of the fuel subsidy, which was launched in March 2010. Notwithstanding a projected sharp rise in investmentrelated imports, the recovery in export prices for Mozambique's key commodities should contain the external current account deficit and keep international reserves at a comfortable level. As outlined below, and in tandem with the improved global recovery, the authorities intend to remove in 2010 last year's fiscal and monetary stimuli.

\section{Donor support was temporarily halted over governance concerns but has}

resumed. Mozambique relies on extensive external assistance for budget financing and economic development. However, development partners expressed political and economic governance concerns that reached a nadir during the October 2009 elections and led to the temporary suspension of budget support in the first quarter of 2010 (Box 1). The authorities' recent steps to assuage these concerns through commitments to donors on governance reforms have led to a resumption of aid in April 2010, which is expected to be disbursed according to original plans. Development partners are closely monitoring implementation of the measures. The resumption of donor support, together with stepped-up foreign exchange sales by the central bank, helped remove pressure on the exchange rate and resulted in a narrowing of the temporarily large wedge between the official and the retail market rate.

\section{Box 1. Agreement on Resumption of Donor Aid}

The October 2009 elections confirmed President Guebuza in office and provided the ruling party with a very large majority. Donors were concerned about a lack of inclusiveness in the democratic process, in particular regarding newly emerging opposition parties. In March 2010, donors' political concerns were addressed through government commitments to reform the electoral law and strengthen the role of opposition parties in parliament. Economic governance concerns centered on the need to improve procurement, strengthen the anti-corruption framework, improve the management of natural resources and concessions, and enhance the business environment. The government committed to measures to address those concerns.

\section{A New PSI-Setting Policies for Sustained Growth}

\section{A. Overview}

6. Mozambique's economic performance and track record of macroeconomic stability over the last decade and a half have been impressive, making the country a prime example of a mature stabilizer. It has achieved strong economic growth, low inflation, comfortable external reserves, and a sustainable debt position thanks to the HIPC/MDRI debt relief. In addition, the country has been resilient to the recent surge in food and fuel prices and, notably, the global economic crisis. This was made possible by the 
authorities' strong commitment to prudent macroeconomic management and by a flexible program design that accommodated the authorities' policy responses to these exogenous shocks. When faced with the global crisis, Mozambique paired its PSI with a high-access ESF which, together with the subsequent SDR allocation, helped shore up the country's international reserves at a critical time.

7. As its current PSI reaches its end, the authorities and staff undertook a retrospective on Mozambique's achievements under the last two Fund-supported programs. This was intended to help draw lessons for the authorities' economic program going forward, especially since Mozambique's macroeconomic challenges remain enormous and the authorities intend to accelerate the country's economic development. Given the authorities' overall satisfaction with the PSI, they opted to request a seamless transition to a successor three-year PSI, which they hoped would help them strengthen their economic policy making and prepare them well for the challenges as a frontier emerging market economy. In this context, the retrospective served a useful role in identifying areas for improving program design. It also triggered the organization of a high-level conference, organized jointly by the authorities, the Bank, and the Fund to debate Mozambique's past achievements, identify the key economic challenges going forward, and outline the main policy options that could help the authorities in facing their macroeconomic challenges.

\section{B. Achievements in Past Programs}

\section{The authorities largely achieved their macroeconomic objectives underlying} Mozambique's fourth PRGF and the current PSI (Figure 2).

- Real GDP growth averaged almost 8 percent during 2004-09, but has trended down from the post-conflict highs following the end of the civil war in the mid-1990s.

Mozambique's growth performance has been similar to that of some fast-growing Asian economies and compares very favorably with the rest of Sub-Saharan Africa (SSA).
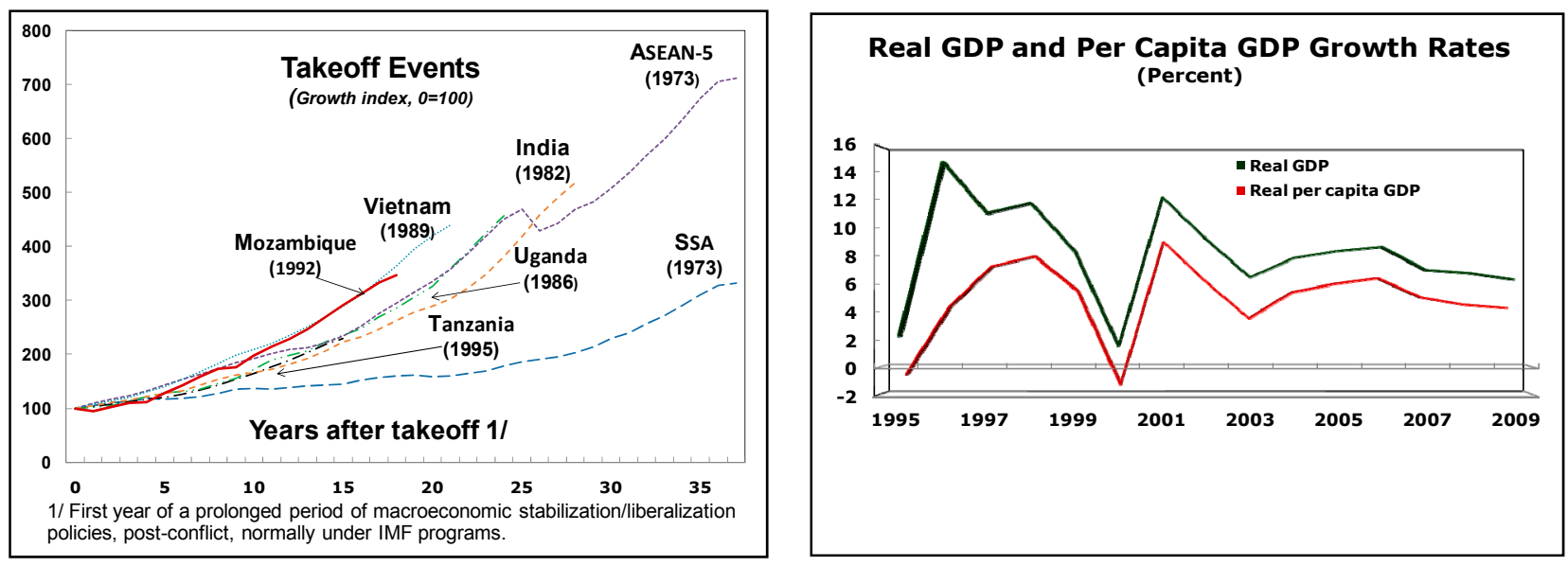
- The poverty rate fell from 69 percent in 1997 to 54 percent in 2003, the last full assessment; the results of the new household survey are expected in the next few months. Per-capita economic growth was strong over the last few years, but it remains below the $25^{\text {th }}$ percentile of the distribution for SSA countries. Some social indicators (e.g., life expectancy, literacy) have improved markedly, but achieving the MDGs remains a challenge in many areas.
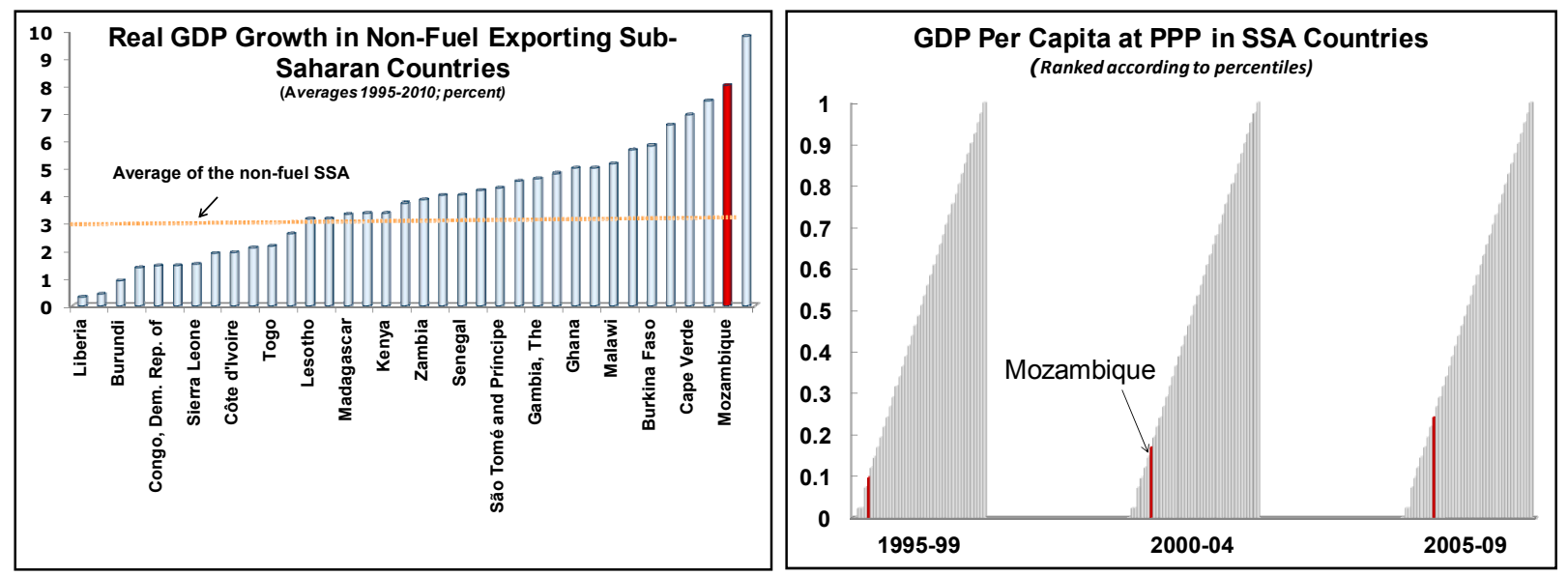

\section{Selected Millennium Development Goals, 1990-2008}

\begin{tabular}{|c|c|c|c|c|c|}
\hline & 1990 & 1995 & 2000 & 2005 & 2008 \\
\hline \multicolumn{6}{|l|}{ Goal 1: Eradicate extreme poverty and hunger } \\
\hline Employment to population ratio, $15+$, total $(\%)$ & 80 & 79 & 79 & 78 & 78 \\
\hline Employment to population ratio, ages $15-24$, total (\%) & 67 & 68 & 67 & 66 & 66 \\
\hline \multicolumn{6}{|l|}{ Goal 2: Achieve universal primary education } \\
\hline Primary completion rate, total (\% of relevant age group) & 26 & 26 & 16 & 42 & 59 \\
\hline Total enrollment, primary (\% net) & $\ldots$ & $\ldots$ & 56 & 76 & 80 \\
\hline \multicolumn{6}{|l|}{ Goal 3: Promote gender equality and empower women } \\
\hline Ratio of female to male primary enrollment (\%) & 76 & 72 & 75 & 84 & 88 \\
\hline Ratio of female to male secondary enrollment (\%) & 57 & $\ldots$ & 63 & 69 & 75 \\
\hline \multicolumn{6}{|l|}{ Goal 4: Reduce child mortality } \\
\hline Immunization, measles ( $\%$ of children ages $12-23$ months) & 59 & 71 & 71 & 77 & 77 \\
\hline Mortality rate, infant (per 1,000 live births) & 166 & 149 & 124 & 103 & 90 \\
\hline \multicolumn{6}{|l|}{ Goal 5: Improve maternal health } \\
\hline Births attended by skilled health staff (\% of total) & $\ldots$ & 44 & $\ldots$ & 48 & 55 \\
\hline Pregnant women receiving prenatal care (\%) & $\ldots$ & 71 & 76 & 85 & 89 \\
\hline \multicolumn{6}{|l|}{ Goal 6: Combat HIVIAIDS, malaria, and other diseases } \\
\hline Prevalence of HIV, total (\% of population ages 15-49) & 1.4 & 4.5 & 9.5 & 12.2 & 12.5 \\
\hline Tuberculosis case detection rate (all forms) & $\ldots$ & 59 & 47 & 47.5 & 48.8 \\
\hline \multicolumn{6}{|l|}{ Goal 7: Ensure environmental sustainability } \\
\hline Improved sanitation facilities (\% of population with access) & 20 & 22 & 27 & 31 & 31 \\
\hline Improved drinking water source (\% of population with access) & 36 & 39 & 41 & 42 & 42 \\
\hline
\end{tabular}

Source: World Development Indicators 
Figure 2. Mozambique: Macroeconomic Developments

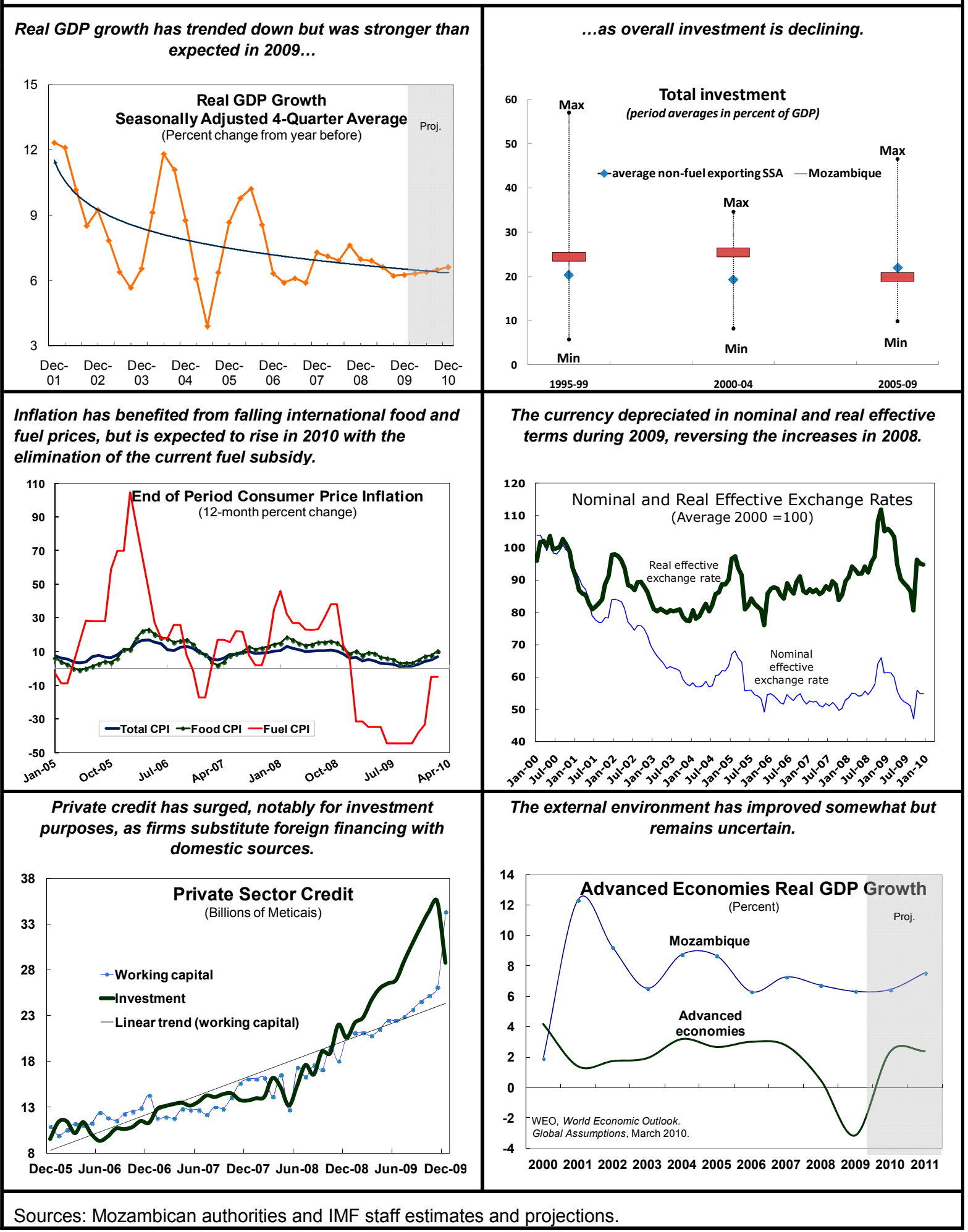


- Inflation has trended down and has generally remained in single digits, except in those episodes of surging international food and fuel prices.

- The current account deficit (after grants) strengthened from around 18 percent of GDP during 2000-03 to about 10 percent of GDP in 2004-09, mainly because of megaproject exports, including in particular from the aluminum smelter Mozal.

- Capital inflows have been high but volatile and averaged 20 percent of GDP during 2004-09. Aid exceeded 13 percent of GDP during the last four years, making donor support a crucial contributor to Mozambique's economic success.

- As a result, Mozambique's international reserves generally surpassed four months of imports and were further boosted in 2009 by access to the ESF and the SDR allocation.

- Mozambique has a low public debt burden and, following MDRI/HIPC debt relief, a low risk of external debt distress.

9. Program performance was generally very strong (Box 2$)$. The authorities showed commendable ownership in pursuing sound economic policies that were underpinned by a focus on structural reforms aimed at enhancing economic policy-making. A protracted period of political stability was also important in securing these results.

\section{The authorities noted that they felt greater ownership under the PSI than under} prior programs. They appreciated the self-discipline imposed by a Fund program, while noting that even though conditionality had declined over time, their commitment to the underlying reforms remained strong - because they wanted to implement those reforms. They also valued the Fund's enhanced flexibility in response to the various exogenous shocks. The authorities saw the program relationship as instrumental in helping them build their capacity in economic policy making. It was mostly felt that a successor PSI would be particularly useful in the current environment when Mozambique is expected to be confronted with more complicated policy issues, such as accessing market financing. In this context, a close engagement with the Fund would provide expertise and act as a counterbalance against overly ambitious and optimistic plans. 


\section{Box 2. A Strong Track Record in Program Implementation Since 2004}

\section{A prudent macroeconomic policy mix aimed to preserve macroeconomic stability:}

- Fiscal policy sought to avoid domestic financing to make room for private sector credit. Fiscal deficits were almost exclusively financed on concessional terms, thanks to strong donor engagement. Nonconcessional borrowing was limited to near zero under the Fundsupported programs.

- Monetary policy successfully managed to contain inflation, relying on reserve money as the operational target.

\section{Program design was flexible:}

- Program targets were loosened to accommodate the authorities' response to the food and fuel price surge and, more recently, to the global crisis.

- The performance criterion (PC) on the domestic primary deficit was relaxed at the fourth PRGF review to use the fiscal space created by the MDRI for additional priority spending. It was subsequently replaced by a PC on net credit to the government, which allowed for unexpected aid to be spent.

\section{Program implementation was strong, reflecting strong ownership:}

- The reviews were completed on time.

- Fiscal policy and NIR targets were generally met. But the reserve money target was regularly overshot because of difficulties in predicting demand for cash in a country transitioning to a banked economy.

- Observance of structural conditionality improved over time. Some two-thirds of structural measures under the PRGF were implemented on time, compared to four-fifths under the PSI. Compliance was the lowest in reforms outside the Fund's area of expertise, reflecting a lack of follow-up by development partners, although compliance improved markedly under the PSI.

- Structural conditionality was streamlined, partly reflecting conditionality reform at the Fund and partly the authorities' growing program ownership. Prior actions were discontinued after the fourth PRGF review in mid-2006. Structural performance/assessment criteria were halved over time and discontinued altogether after the third PSI review in late 2008.

- Structural conditionality focused on measures within the Fund's core area of expertise and was supported by extensive technical assistance (TA) on public financial management (PFM), tax policy and administration, and monetary and financial sector policies. Its selection benefited from close cooperation between the area and functional departments, and the TA coordinator operating from the local Fund office. 


\section{Mozambique's Macroeconomic Challenges}

\section{After enjoying an impressive recovery in the decade and a half following the end} of the civil war, economic expansion has gradually been decelerating and become dependent on megaprojects in the natural resources sector. Notwithstanding the contribution of megaprojects to growth, ${ }^{2}$ their spillovers to the rest of the economy have been limited, owing to shallow vertical and horizontal integration, high physical capital intensity, profit repatriation patterns, and low tax revenue contributions. As a result, sectoral contributions to growth have been uneven, with a still subdued participation of the private sector outside the megaprojects. Private investment has not taken off as much as in most peer countries, little employment has been generated, and development indicators, while improving, are still low. In addition, the traditional export sector has lagged behind, which has led to a concentration of the export base and a heightened external vulnerability. By end-2008, exports of aluminum, electricity, and natural gas accounted for about 60 percent of total exports.
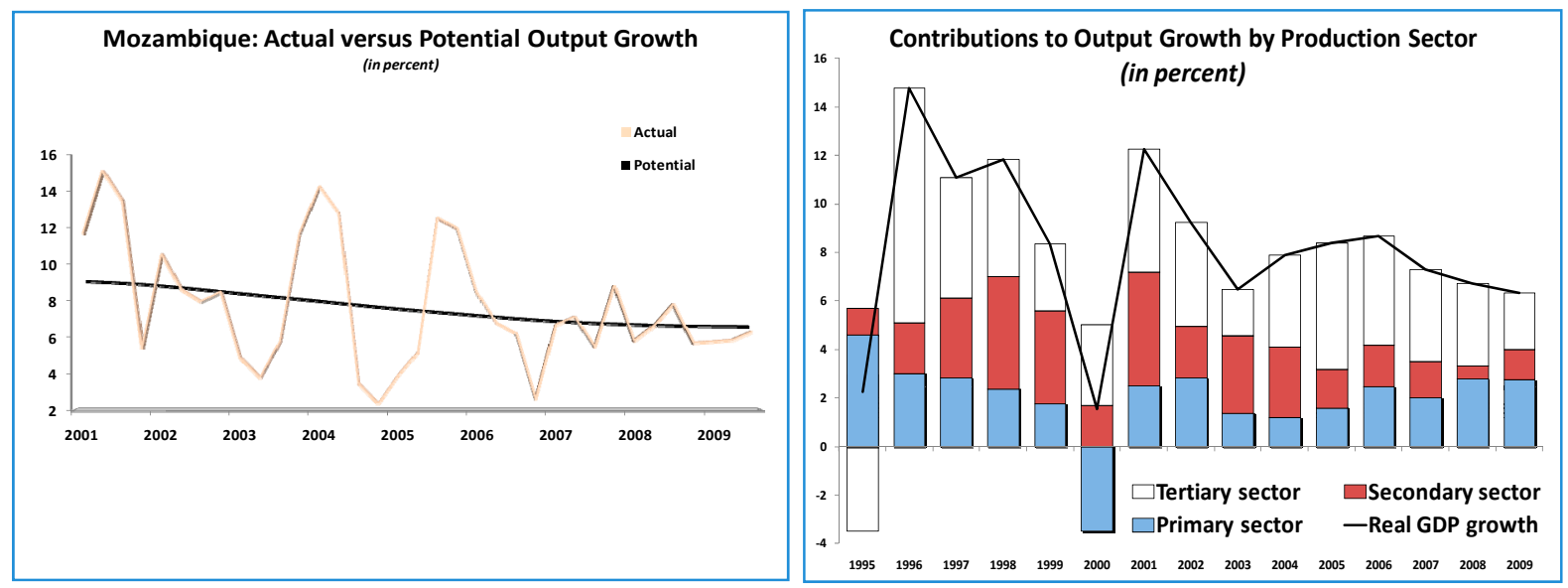

\section{A sustained improvement in living standards would require policies to diversify}

\section{the country's productive and export base and increase the role of the private sector.} Those policy challenges were discussed during a three-day high-level conference in the midst of the program negotiation mission. The conference, which helped shape the program discussions, was held in Namaacha (southern Mozambique) and organized jointly by the authorities, the Bank, and the Fund. Bank and Fund staff were subsequently invited to present the conference's conclusions to a special meeting of the Council of Ministers in the capital Maputo (Box 3).

\footnotetext{
${ }^{2}$ Megaprojects dominate the economic activity in the secondary sector, and waves of new megaprojects have triggered a rise of the sector's contribution to GDP growth. During the post-conflict economic expansion, the secondary sector grew by 13 percent on average, while the primary and the tertiary sectors grew by $7 \frac{1}{2}$ percent respectively. As a result, the production share of the secondary sector rose from 12 to 23 percent, while that of the primary sector fell from 29 to 26 percent, and that of the tertiary sector from 59 to 52 percent.
} 


\section{Box 3. Namaacha Conference on Mozambique's Economic Challenges and Policy Options}

The three-day conference was attended by 140 participants, including current and former members of government, senior managers of line ministries, and representatives of the private sector, academia, civil society, and development partners. It received wide media coverage. The format emphasized a collaborative approach, in which Fund and Bank staff introduced each topic with an analytical presentation, which was followed by the authorities' analysis and a subsequent panel and open-floor discussion of the issue at stake.

There was broad recognition of Mozambique's impressive economic growth and macroeconomic stability since the end of the civil war - an achievement that needed to be preserved. At the same time, growth had been trending down, and a large part of the population still lives below the poverty line. There was agreement that in order to sustain higher and more inclusive economic growth going forward, the government would need to encourage economic activity driven by the private sector. Various strategies were discussed, including boosting public investment, creating a more enabling business environment, developing key sectors in the economy, enhancing regional integration with neighboring countries, and better tapping Mozambique's comparative advantages.

The last day of the seminar was devoted to the need for informed borrowing decisions should Mozambique decide to tap financing at commercial terms. Bank and Fund experts explained the advantages and pitfalls of various financing instruments, including bonds, (syndicated) loans, financing from bilateral development banks, and Public-Private Partnerships (PPP). They also urged the authorities to build institutional capacity for improved debt management and to develop a multi-year strategy to guide them in their external and domestic borrowing.

\section{Raising the country's growth and export potential would thus hinge on creating} an environment conducive to private sector activity. The authorities' thinking is centered on boosting public investment, with a view to expanding the transportation and electricity networks in the vast country to allow private sector activity to emerge. Such investment could partially be financed by nonconcessional external resources if efforts to raise additional concessional funds and strengthen revenue collections proved insufficient.

\section{Staff analysis supports the potential merits of boosting investment but urges a} cautious approach. Mozambique's capital abundance and investment rates, especially private investment, are very low indeed (Box 4). However, staffs' simulations show that a permanent increase in public investment over the next two decades financed exclusively at market terms, would noticeably worsen Mozambique's debt indicators and impact macroeconomic stability. This suggests that the

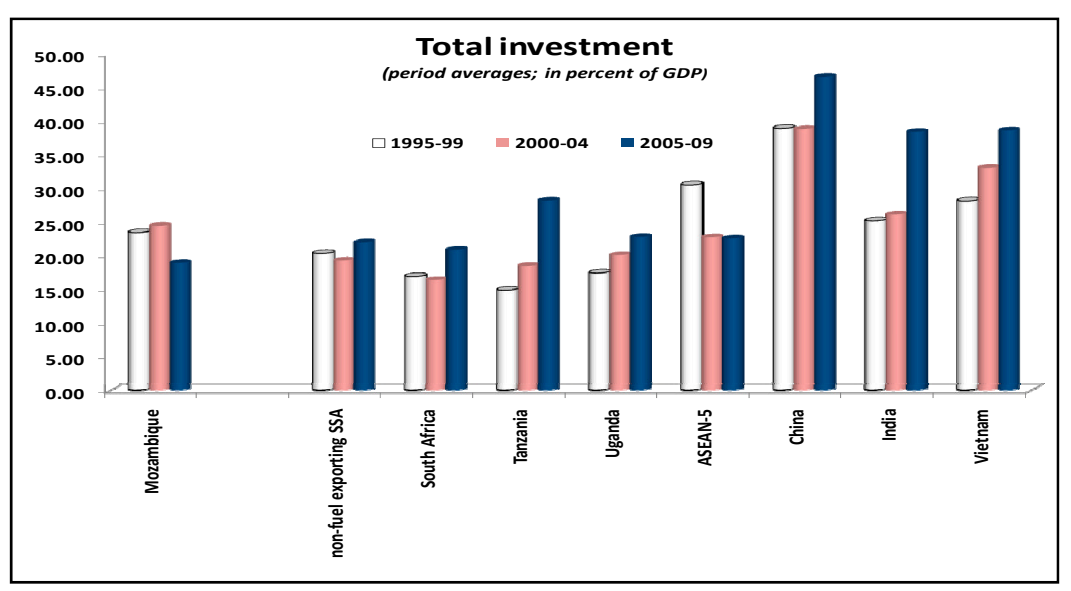
authorities should adopt a more limited and time-bound scaling up of their investment. Emphasis should also be placed on the quality of projects so as to ensure an adequate growth dividend and the ability to repay the additional borrowing. This in turn hinges on the development of a consistent cross-sectoral investment strategy that would prioritize projects 
based on feasibility studies and cost-benefit analyses and their potential to promote private investment. This crowding in of private investment appears to be Mozambique's most promising avenue to create jobs and reduce poverty.

\section{Box 4. Empirical Evidence on the Determinants of Economic Growth}

Staff conducted an empirical analysis of the determinants of growth in living standards in Mozambique, to assess how investment in infrastructure contributes to it. The results suggest that a 1 percent increase in the rate of public investment could raise output growth by up to 0.5 percent on impact, whereas a 1 percent increase in the rate of private investment could raise output growth by up to 1.3 percent on impact.

These results indicate that public investment in infrastructure, where Mozambique still ranks in the bottom percentile and below SSA averages, could yield higher growth, provided the business environment and economic governance improve as well. But the persistence of the expansionary effect of public investment will depend on the degree to which it promotes future private investment. To achieve this, public investment should be well targeted to raise the benefits and reduce the costs of private investment.
Estimation results for panel error correction model of output per capita growth

\begin{tabular}{lcc}
\hline \hline & Advanced Economies Included & Advanced Economies Excluded \\
\hline Short run dynamics: Coefficients & & \\
Lagged output per capita & 0.035 & 0.034 \\
Foreign output per capita & $0.042^{* * *}$ & $0.042^{* * *}$ \\
Real interest rate & $-0.201^{* *}$ & $-0.225^{* *}$ \\
Real effective exchange rate & -0.005 & -0.006 \\
Long run disequilibrium & $-0.280^{* * *}$ & $-0.274^{* * *}$ \\
\hline Long run trend: Parameters & & \\
Productivity growth rate & $0.018^{* * *}$ & $0.016^{* * *}$ \\
Private physical capital intensity & $0.160^{* * *}$ & $0.164^{* * *}$ \\
Public physical capital intensity & $0.060^{*}$ & $0.059^{*}$ \\
Human capital intensity & 0.030 & 0.024 \\
\hline Diagnostics: & & \\
Observations & 2155 & 1967 \\
R Squared & 0.206 & 0.197 \\
\hline \hline
\end{tabular}

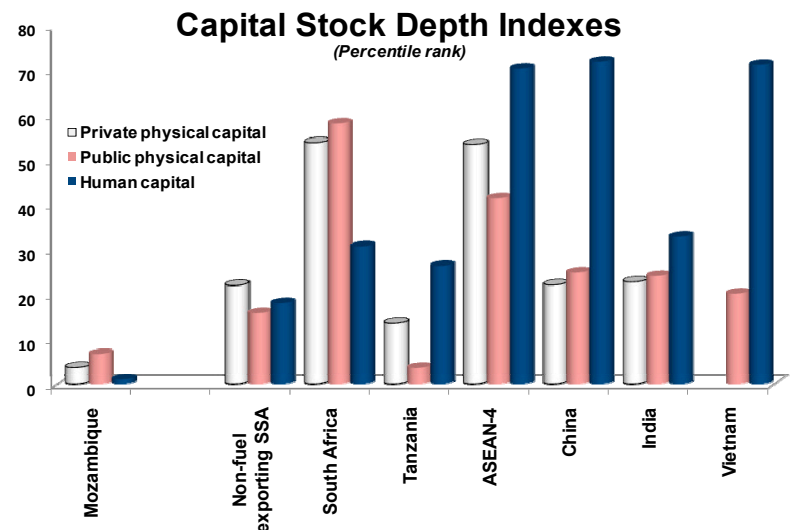

15. Various analyses, including by the Bank, also suggest a need to better tap Mozambique's comparative advantages. ${ }^{3}$ Those include an abundance of arable land and the country's geographical location, which suggest enormous possibilities to enhance regional trade (especially with its landlocked neighbors) and develop key industries, such as agro-industries, textile, and tourism. Such sectoral growth strategies would in turn also benefit from the authorities' plans to develop infrastructure. But all efforts to develop the country would be
Mozambique's Ranking in Doing Business, 2010

\begin{tabular}{lc}
\hline Indicator & Rank \\
\hline Ease of Doing Business & 135 \\
Starting a business & 96 \\
Dealing with construction permits & 159 \\
Registering property & 151 \\
Getting credit & 127 \\
Protecting investors & 41 \\
Paying taxes & 97 \\
Trading across borders & 136 \\
Enforcing contracts & 129 \\
Closing a business & 136 \\
\hline
\end{tabular}

Source: The World Bank Group, Doing Business Indicators, 2010.

${ }^{3}$ See Mozambique, Country Economic Memorandum, forthcoming. 
impaired if the authorities failed to step up their efforts to improve the business climate, since Mozambique ranks well behind its SSA peers in survey-based indicators.

\section{The Design of the New Program}

MEFP $\mid 5-10$

\section{Striking the balance between economic development and macroeconomic stability}

16. The successor PSI intends to support the authorities' development objectives while safeguarding macroeconomic stability. The authorities aim to create the conditions for sustainably raising economic growth and reducing poverty. They are adamant that meeting their development needs now requires significantly stepping up public investment in transport and electricity infrastructure, which would necessitate broadening the financing options to also include nonconcessional borrowing and expand reliance on concessions and PPPs. They see such infrastructure investment as a key prerequisite to boost regional trade and private sector activity throughout the country, which they intend to complement with enhanced efforts to improve the business climate. These developmental objectives notwithstanding, the authorities reiterate that safeguarding macroeconomic stability continues to be their overriding priority.

17. A time-bound increase in public investment could be consistent with maintaining macroeconomic stability, as well as debt sustainability, but is not without risks. It would require a changed fiscal policy stance over the next few years that would aim at creating the fiscal space to implement the authorities' investment priorities. This would mainly be achieved through a sustained revenue effort and an increasing recourse to nonconcessional and domestic borrowing. Staff and the authorities agreed that the virtually zero limit on nonconcessional external borrowing under Mozambique's last two Fund-supported programs was inconsistent with the country's vast developmental needs and should be relaxed, allowing Mozambique to reap the benefits from its strong track record of prudent macroeconomic policies and comfortable debt indicators. In addition, the sharp increase in financial intermediation provides some room to increase domestic financing of the budget without the risk of crowding out private sector credit. However, an excessive and permanent - versus a contained and time-bound - expansion of public investment could undermine debt sustainability, create undesirable domestic demand pressures, and strain institutional capacity.

\section{The program embeds the expansion of the authorities' public investment} program in transportation and energy infrastructure over the next three years in a prudent macroeconomic policy mix. The authorities committed to a policy stance that would keep the domestic primary balance broadly stable during the program period and tighten monetary policy to ward off inflationary pressures while supporting a continued financial deepening. 
19. The envisaged policy stance is not expected to increase domestic demand pressures nor burden the current account and reserve levels. The high import component and external financing of the planned investment and underutilized labor markets should contain inflationary effects and prevent a crowding out of private investment. While the higher imports could potentially worsen the external current account deficit, they are expected to be broadly offset by a recovery in export prices and a larger and more diversified export base arising from the coming online of new megaprojects in the natural resources sector. ${ }^{4}$ This should also help

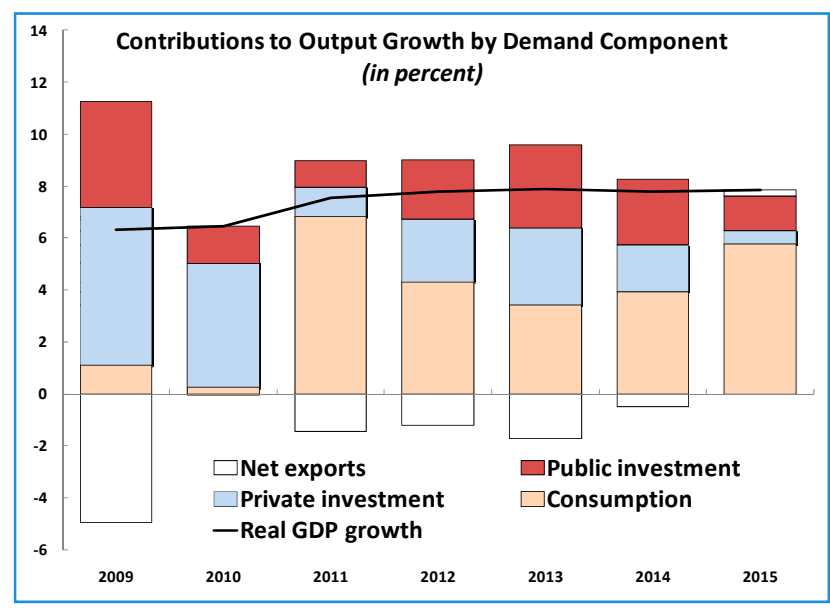
broadly stabilize Mozambique's reserve cover over the medium term and prepare the country well for the challenge to service the debt from the envisaged new external borrowing.

Selected Indicators, 2008-15

\begin{tabular}{|c|c|c|c|c|c|c|c|c|}
\hline & 2008 & 2009 & 2010 & 2011 & 2012 & 2013 & 2014 & 2015 \\
\hline & \multicolumn{2}{|c|}{ Actual } & \multicolumn{6}{|c|}{ Projections } \\
\hline Real GDP, percent change & 6.7 & 6.3 & 6.5 & 7.5 & 7.6 & 7.9 & 7.8 & 7.8 \\
\hline Inflation, eop, percent change & 6.2 & 4.2 & 8.0 & 5.6 & 5.6 & 5.6 & 5.6 & 5.6 \\
\hline Inflation, average, percent change & 10.3 & 3.3 & 9.3 & 5.6 & 5.6 & 5.6 & 5.6 & 5.6 \\
\hline Current account deficit (after grants), percent of GDP & -11.9 & -11.9 & -13.6 & -12.8 & -13.5 & -13.4 & -13.0 & -12.8 \\
\hline Gross external reserves, months of projected imports & 4.6 & 5.1 & 4.9 & 5.3 & 5.6 & 5.7 & 5.5 & 5.3 \\
\hline Primary domestic fiscal deficit, percent of GDP & -3.2 & -4.4 & -4.2 & -4.6 & -4.4 & -4.0 & -3.8 & -3.7 \\
\hline Overall fiscal deficit (after grants), percent of GDP & -2.3 & -5.6 & -4.7 & -7.2 & -6.8 & -6.1 & -5.3 & -5.1 \\
\hline Fiscal external financing, percent of GDP & 4.0 & 5.1 & 4.3 & 6.3 & 5.9 & 5.4 & 4.5 & 4.3 \\
\hline Net credit to government, percent of GDP & -1.7 & 0.3 & 0.3 & 0.9 & 0.9 & 0.7 & 0.8 & 0.8 \\
\hline Private sector credit, percent change & 45.9 & 58.6 & 19.1 & 14.0 & 14.9 & 15.8 & 15.7 & 15.8 \\
\hline Private sector credit, percent of GDP & 18.8 & 27.1 & 27.8 & 27.9 & 28.1 & 28.6 & 29.1 & 29.6 \\
\hline Reserve money, percent change & 7.8 & 27.3 & 19.5 & 14.7 & 15.0 & 15.1 & 14.9 & 15.0 \\
\hline
\end{tabular}

20. Should contrary to expectations the investment program overextend the capacity of the economy, the authorities stand ready to adjust macroeconomic policies accordingly. They will pay special attention to the emergence of inflationary pressures and signs of a crowding out of the private sector. In this case, they would tighten monetary policy and revisit their budgetary spending plans so as to contain the government's financing needs.

\section{The structural reform focus under the successor PSI}

should help shore up the authorities' policy objectives. The reforms aim to strengthen the authorities' economic management capacity to

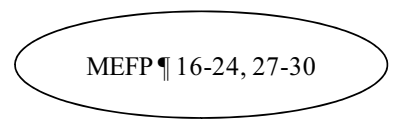
help them cope better with the increasingly sophisticated policy environment emanating from, in particular, the possible access to market borrowing and related challenges to the coordination of fiscal and monetary policies. As such, the initial focus of structural conditionality will be on enabling the authorities to make informed decisions with respect to

\footnotetext{
${ }^{4}$ The Rio Doce coal mine is expected to launch production and exports in 2011 , and investment is ongoing to allow an increase in Mozambique's natural gas and titanium exports by half during 2011-13.
} 
the financing of their investment program, by strengthening debt management, supporting the development of a coherent borrowing strategy, and creating a sound framework for PPPs and concessions. In tandem with the authorities making progress in those areas, it is expected that the focus of structural conditionality will shift back over time to the ongoing reforms to strengthen public financial management, modernize tax policy and administration, support the BM's move toward an inflation targeting framework, and foster financial sector soundness and deepening. Extensive Fund TA is being provided in those areas, which will facilitate the selection of priority measures for future conditionality during the course of the three-year program. Any reform measures outside of the Fund's core areas of expertise, such as on improving the business environment, will be taken up by other development partners.

Mozambique: Proposed Structural Benchmarks under the Successor PSI, 2010

\begin{tabular}{|c|c|c|c|}
\hline Structural Benchmarks & $\begin{array}{l}\text { Reference } \\
\text { Paragraph in the } \\
\text { MEFP }\end{array}$ & Macroeconomic Relevance & $\begin{array}{l}\text { Expected Date of } \\
\text { Implementation }\end{array}$ \\
\hline $\begin{array}{l}\text { Any new contracting of nonconcessional external borrowing } \\
\text { or guarantees by the Central Government and selected state- } \\
\text { owned entities (SOEs) subject to the related continuous } \\
\text { quantitative AC will be for transportation and electricity } \\
\text { infrastructure investment. }\end{array}$ & 14,15 & $\begin{array}{l}\text { Channel more costly financial resources to sectors that have } \\
\text { the potential to raise the country's growth potential, thereby } \\
\text { supporting debt sustainability. }\end{array}$ & Continuous \\
\hline $\begin{array}{l}\text { Adoption by Council of Ministers of PPP, Concessions and } \\
\text { Megaprojects Law. }\end{array}$ & 22 & $\begin{array}{l}\text { Reinforce investment planning, limit fiscal and quasi-fiscal } \\
\text { risks, and maximize economic benefits. }\end{array}$ & End-September 2010 \\
\hline $\begin{array}{l}\text { Finalization of a comprehensive debt strategy that will } \\
\text { assess the risk profile and the fiscal and macroeconomic } \\
\text { implications of new borrowing. }\end{array}$ & 16 & $\begin{array}{l}\text { Safeguard macroeconomic stability and debt sustainability } \\
\text { through informed borrowing decisions. Support development } \\
\text { of domestic financial markets. }\end{array}$ & End-November 2010 \\
\hline Completion of first Government Debt Sustainability Analysis. & 17 & $\begin{array}{l}\text { Enhance the authorities' capacity to make informed decisions } \\
\text { about borrowing options and the evaluation of risks to } \\
\text { macroeconomic stability and debt sustainability. }\end{array}$ & End-September 2010 \\
\hline
\end{tabular}

\section{Creating fiscal space to step up public investment}

\section{The adjusted policy mix aiming to support Mozambique's development objectives} hinges on the creation of new fiscal space. During the past two Fund-supported programs, Mozambique successfully created fiscal space primarily through a sustained revenue effort and expanded donor support, which underpinned an expansion of both current and capital spending. Going forward, the program envisages the creation of additional fiscal space through a further increase in revenue collections ( $1 \frac{1}{2}$ percent of GDP), a moderate expansion of domestic financing ( $1 / 2$ percent of GDP), and nonconcessional external borrowing ( $2 \frac{1}{2}$ percent of GDP); gross aid flows are projected to decline somewhat during the program period. The revenue effort reflects the ongoing improvements in tax administration and tax policy under the program, which are being supported by Fund TA. ${ }^{5}$ This additional fiscal space will largely be channeled to support the public investment program (Box 5).

\footnotetext{
${ }^{5}$ A recent assessment of the tax system concluded that Mozambique's potential tax ratio could exceed 21 percent of GDP in the long run. See International Monetary Fund, 2009, "Evaluation of Reforms in Tax Policy and Administration in Mozambique and Related TA - 1994-2007”.
} 
Mozambique: Creation of Fiscal Space

\begin{tabular}{lrr}
\hline & 2005-09 & $2010-13$ \\
\hline Source of fiscal space & (Cumulative change in percent of GDP) \\
Domestic contribution & 6.2 & 2.9 \\
Revenues & 4.2 & 1.4 \\
Domestic interest payments & 4.7 & 1.2 \\
Domestic financing (net) & 0.4 & -0.1 \\
Privatization receipts & 0.9 & 0.4 \\
External contribution & -1.8 & -0.1 \\
Grants & 2.1 & 1.5 \\
Project & 1.8 & 0.4 \\
Nonproject & 1.3 & 0.9 \\
Concessional external financing & 0.5 & -0.4 \\
Nonconcessional external financing 1/ & 0.3 & -1.1 \\
Use of fiscal space & 0.0 & 2.2 \\
Total current expenditures (excl. unallocated) & 6.2 & 2.9 \\
Of which: wages & 3.8 & 0.5 \\
Other current spending & 1.8 & -0.1 \\
Unallocated revenues/expenditures 2/ & 2.0 & 0.6 \\
Development expenditures & -0.9 & 0.0 \\
Memorandum items: & 3.3 & 2.5 \\
Source of fiscal space (including Portuguese loan) & & \\
Use of fiscal space (including Portuguese loan) & $\ldots$ & $\ldots$ \\
\hline
\end{tabular}

Source: IMF staff calculations

1/ Excludes the Portuguese credit line that will be implemented by the Road Fund.

2/ Corresponds to the reduction of unclassified or unrecorded transactions, which was made possible by the public financial management system reforms.

\section{The stepped-up investment program will not compromise Mozambique's}

\section{traditionally prudent fiscal policy stance.}

While the overall fiscal deficit (after grants) will temporarily rise by about 2 percentage points, to a peak of about 7 percent of GDP by 2011 , the domestic primary deficit will remain broadly stable at its current level of about 4 to $4 \frac{1}{2}$ percent of GDP during the program period. This represents a tightening relative to 2009, as the authorities intend to unwind the fiscal stimulus from the crisis year and contain current expenditure. In addition, consistent with their program commitments, they initiated the removal of

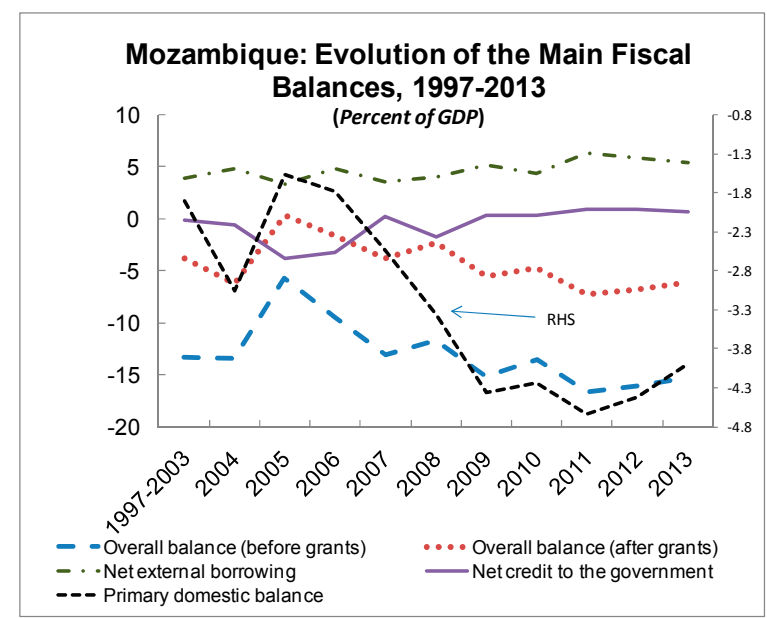
the fuel subsidy, which accounted for spending of above 1 percent of GDP in 2009; as a result, since end-March, average retail fuel prices have been adjusted in two steps by a cumulative 30 percent.

\section{The authorities remain committed to expanding priority social}

expenditure. This is consistent with their poverty reduction strategy (PARPA), MEFP $₫ 18$ which is expected to be updated this year. The PARPA-defined priority expenditure averaged three-fifths of total spending during 2007-09, which the authorities intend to broadly maintain going forward. An indicative floor to this effect was introduced to the program. 


\section{Box 5. The Authorities' Investment Priorities}

The authorities plan to step up their public investment program over the medium term. They expect that several of the key projects will enjoy financing and/or co-financing from development partners and be implemented through either the budget or selected state-owned enterprises (SOEs), such as the Road Fund, the water utility (FIPAG), and the electricity company (EDM). ${ }^{1 /}$ Some projects are planned to be developed under a concession or a PPP, for which the legal framework will be strengthened under the program (a structural benchmark).

The increase in the public investment program aims to remove bottlenecks in transportation and energy infrastructure. The authorities are currently

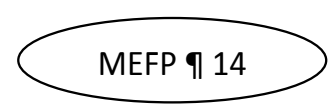
assessing the prioritization and sequencing of infrastructure investment projects and expect to complete this process by the time of the first program review. Current indications point toward a front-loaded expansion of the investment program of 5 $1 / 2$ percent of GDP over the next two years, which would abate somewhat thereafter. The MEFP provides an overview of some key projects that at present enjoy the authorities' priorities.

Mozambique: Total Public Investment Program, 2009-15

\begin{tabular}{lrrrrrrr}
\hline & 2009 & 2010 & 2011 & 2012 & 2013 & 2014 & 2015 \\
\hline & & \multicolumn{7}{c}{ (Percent of GDP) } \\
& 13.1 & 15.4 & 18.6 & 18.4 & 18.0 & 17.4 & 17.3 \\
Total & 13.1 & 13.9 & 17.1 & 17.0 & 16.8 & 16.3 & 16.5 \\
$\quad$ On budget & 4.5 & 6.1 & 6.5 & 6.8 & 6.9 & 7.0 & 7.3 \\
$\quad$ Domestically financed & 8.6 & 7.8 & 7.8 & 7.8 & 7.8 & 7.8 & 7.8 \\
$\quad$ Donor financed, concessional & 0.0 & 0.0 & 2.8 & 2.5 & 2.2 & 1.6 & 1.4 \\
$\quad$ Non-concessional & 0.0 & 1.4 & 1.6 & 1.4 & 1.2 & 1.1 & 0.8 \\
$\quad$ Credit line from Portugal 1/ & 0.0 & 0.8 & 0.9 & 0.8 & 0.7 & 0.6 & 0.5 \\
$\quad$ Concessional & 0.0 & 0.6 & 0.7 & 0.6 & 0.5 & 0.5 & 0.4 \\
$\quad$ Nonconcessional & & & & & & & \\
$\quad$ Memorandum items: & & & & & & & \\
$\quad$ Total concessional and domestic & 13.1 & 14.7 & 15.2 & 15.3 & 15.3 & 15.4 & 15.5 \\
$\quad$ Total nonconcessional & 0.0 & 0.6 & 3.5 & 3.1 & 2.7 & 2.0 & 1.8 \\
\hline
\end{tabular}

Source: IMF staff calculations.

1/ Portuguese credit line that will be implemented by the Road Fund.

The authorities intend to maximize the return on investment. They plan to focus on projects that they consider could play a pivotal role in improving MEFP q 14-18 transportation links between economic centers and to border posts with Mozambique's neighbors, including landlocked Zimbabwe and Malawi. This is expected to stimulate private sector activity and economic growth. They are assessing the scope of recovering the investment and borrowing costs for some projects through concessions, user fees, and tolls, such as for key road corridors, bridges, and the power transmission line from the Cahorra-Bassa dam to the capital city Maputo; several existing roads and bridges are already toll-based. All such planned projects will be based on feasibility studies, including in some cases also from participating development partners. A continuous structural benchmark will ensure that all projects financed by nonconcessional resources subject to the related assessment criterion under the PSI will be in the transportation and energy sectors.

${ }^{1}$ The assessment criterion on nonconcessional borrowing is defined to include these three SOEs. It excludes commercially viable companies, namely Portos e Caminhos de Ferro de Mocambique (the company in charge of the rail system and the country's five ports), LAM (the airline company), and CMH (the company in charge of exploration and processing of natural gas), as well as smaller public entities. In general, the statutes of SOEs require approval by the Minister of Finance on all commercial borrowing. A new Law on Public Enterprises will enhance the reporting of SOEs to the Minister of Finance (see MEFP q22). 
25. The authorities intend to broaden coverage of the budget. While at present the fiscal stance is measured on a central government basis, the

MEFP $\mid 19$ authorities will expeditiously work toward integrating the Road Fund, the water authority (FIPAG), and the electricity company (EDM) into their fiscal analysis. To this end, they will develop a fiscal template that will consolidate the revenue, expenditure, and financing of the central government and those entities, which should allow a regular reporting of quarterly consolidated fiscal accounts later this year. The planned Law on Public Enterprises will further stipulate the reporting requirements of SOEs to the government.

Adapting the borrowing strategy and improving decision making

MEFP $q 15-17$

26. The authorities firmly indicated that concessional financing would remain their preferred choice of financing. Nonetheless, they would assess the availability of other financing options - including the possibility of higher domestic borrowing and tapping nonconcessional external resources - to advance their public investment program in transportation and energy infrastructure. The authorities have informed development partners of their intention in this regard, reiterating that the accelerated infrastructure investments are additive to the existing development programs (especially health, education, capacity building) for which donor support will continue to be essential to help meet the country's development objectives.

\section{The fiscal program allows for higher domestic and external borrowing, over a} limited time horizon, to implement the high-priority infrastructure projects. Staff's analysis suggests that limited recourse to domestic financing of up to 1 percent of GDP per year and untied nonconcessional external borrowing averaging $2 \frac{1}{2}$ percent of GDP per year (a cumulative US $\$ 900$ million during the program period), with a commensurate increase in the overall fiscal deficit, could be consistent with macroeconomic stability and debt sustainability, using prudent assumptions on the growth dividend, the revenue response, and financing terms. ${ }^{6}$ The envisaged larger domestic financing is also expected to help develop domestic financial markets and leave sufficient room for the credit to the private sector.

\section{The accompanying debt sustainability analysis confirms Mozambique's low risk} of debt distress but identifies heightened vulnerabilities. While key debt indicators remain under the relevant debt burden thresholds under the Bank-Fund debt sustainability framework (DSF), the thresholds are temporarily exceeded under some stress tests. Consequently, the risk of the new borrowing needs to be carefully managed. To this end, the program includes important commitments to enhance the authorities' capacity to identify and implement priority projects and step up debt management (Box 6).

\footnotetext{
${ }^{6}$ For 2010, the authorities intend to tap nonconcessional financing from bilateral development banks to advance priority projects. Over the medium term, the choice of financing will be determined on the basis of the debt strategy that is being developed (see Box 6 below).
} 


\section{Box 6. Enhancing Investment Planning and Debt Management}

Building the capacity to manage risks related to borrowing on nonconcessional terms, the choice of investment projects, and the granting of concessions and PPPs will be a central focus under the program. TA from the Fund and the Bank has been lined up to support the authorities in these endeavors. The following structural reforms were agreed upon:

Debt strategy. By end-November 2010, the government will finalize a multi-year debt strategy (structural benchmark). Key elements of the strategy will include

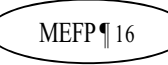
steps to derive an annual borrowing profile and calendar, lengthen the maturity structure to help extend the domestic yield curve, develop the institutional framework of domestic financial markets, and identify possible external financing options.

Debt management. The institutional framework for debt management will be enhanced to help the government make informed decisions about borrowing MEFP 17 options and the evaluation of possible risks. To this end, the debt unit in the ministry of finance (MOF) will receive additional staff and be supported in its work by the creation of a debt monitoring committee (DMC) with members of specialized services from other public institutions, such as the central bank. The beefed-up technical expertise will be a strong foundation for the authorities producing their first semiannual debt sustainability analysis (DSA). The first analysis will be completed and published by end-September 2010 (structural benchmark).

Investment planning. A new legal framework for PPPs and concessions will be adopted by the Council of Ministers by end-September 2010 (structural benchmark). The law is expected to follow best practices in terms of financial management, accounting, and risk sharing with the private sector. It will formalize the PPP approval process, introduce 'gateway' decision points whereby the consensus of the Ministry of Finance would be required before a PPP can proceed, and create a new PPP unit in the Ministry of Finance to support the gateway process and improve financial oversight of PPPs.

\section{Continuing with fiscal structural reforms to shore up public finance objectives}

\section{The government is determined to press ahead with reforms to shore up public}

finances. Based on extensive TA from the Fund and other development partners, the government will continue to implement measures to modernize tax policy and administration, strengthen PFM, and improve economic governance. Many of the measures are part of a multi-year effort that is also embedded in performance benchmarks under the harmonized donor support framework (Performance Assessment Framework, PAF).

\section{Containing inflation and strengthening the monetary policy framework}

30. Monetary policy will continue to aim at maintaining low inflation while making sufficient room for credit to the private sector. The BM aims to contain inflation to below 6 percent over the medium term, with a temporary spike to 9 percent in 2010 arising from spillovers of the removal of the fuel price subsidy. The BM remains committed to maintaining its flexible exchange rate regime, which has enabled it to successfully reduce inflation to single-digit levels and tackle the challenges from the scaling up of aid. This bodes well for the 
BM facing the new challenges from the increased external borrowing by the government to finance its investment program. In its management of the exchange rate, the BM will pay close attention to the effective exchange rate vis-àvis a broad basket of currencies, which should prevent a repeat of the temporary overvaluation of the exchange rate in 2008-09 that arose from a focus on the bilateral exchange rate with the U.S. dollar; this overvaluation has in the meantime been reversed.

31. The BM will continue to rely on reserve money as its operational target in the near future. Reserve money growth will be consistent with an assumed further strengthening in money demand and rising financial intermediation. However, the program target is now defined as a monthly average instead of an end-period stock so as to neutralize somewhat the end-month spike in currency demand when wages and salaries are being paid. Staff analysis suggests that this should enhance the ability of the BM to meet the program target.

\section{In 2010, the BM will aim to unwind the monetary expansion made necessary by} the global crisis, as private operators are expected to revert to their traditional external funding sources. As a result, a marked slowdown in credit to the private sector is projected for this year. As a first step, the BM increased its key policy rate (FPC) from $11 \frac{1}{2}$ to 12 $\frac{1}{2}$ percent in April 2010.

33. The BM will decide whether to move to an inflation targeting framework over the next two years. Based on significant Fund TA, the BM is in the process of tackling some of the prerequisites for a successful transition, as outlined in the relevant action plan. Specifically, the BM needs to: (i) decide which inflation rate will be targeted and what core inflation rate should be used to assess inflationary conditions $;^{7}$ (ii) enhance its monitoring, understanding, and capacity to project the monetary transmission mechanism; (iii) strengthen its monetary instruments to steer monetary conditions effectively; and (iv) improve its communications strategy with the private sector. The BM is also working on improving its liquidity demand forecasting to better capture the ongoing shift toward a banked economy, as banking services are gradually being rolled out throughout the country.

\section{With nonconcessional and domestic borrowing set to substantially increase} during the program period, liquidity and foreign exchange management will be particularly challenging. Capital inflows would tend to affect the exchange rate before spending is absorbed in investment-related imports. If the project implementation and related imports are not well timed with borrowing decisions, the lag could lead to temporary appreciation and excess liquidity. If prolonged, this would require selling reserves or issuing $\mathrm{t}-$ bills to sterilize the excess liquidity. Large inflows will therefore require greater sterilization and coordination between the BM and the government, and the implementation of a costsharing mechanism, which still need to be concluded. The BM will need to carefully balance its sterilization operations: while it has to ensure adequate foreign reserves to meet later debt

\footnotetext{
${ }^{7}$ The recent multi-topic STA mission concluded that there is a significant downward bias in the CPI, which the authorities need to address urgently, with bilateral technical assistance.
} 
service payments, the BM will also need to guard against excessive reserve accumulation that would limit the effective external absorption of capital inflows and constrain private sector credit growth.

35. The authorities are currently taking actions to remove the existing exchange restrictions on the making of payments and transfers for current international transactions subject to approval under Article VIII of the Fund's Articles of Agreement through adoption of foreign exchange regulations. Following the adoption of the foreign exchange law that came into effect on March 11, 2009, they have been working on the implementing regulations that are intended to remove the remaining exchange restrictions. While the drafting process of the implementing regulations has been delayed, as the authorities had reassigned staff to enhance the supervision of the financial sector in the wake of the global crisis, the adoption of the regulations is now near completion, since they are scheduled to be adopted by the Council of Ministers in August 2010, following consultations with the private sector (especially commercial banks) during June/July. The implementation regulations are intended to eliminate the remaining exchange restrictions on the making of payments and transfers for current international transactions, and staff will review the regulations in order to confirm this. The authorities have communicated to staff that they intend to accept their obligations under Article VIII of the Fund's Articles of Agreement following the issuance of the regulations.

\section{Safeguarding financial sector soundness}

36. Several steps will be implemented to strengthen the financial sector. The government and the BM will ensure expeditious follow-up on the recommendations of the 2009 Financial Sector Assessment Program (FSAP) update and recent TA. It will develop a Financial Sector Action Plan to implement the FSAP recommendations by end-July 2010, step-up risk management, and develop deposit insurance. Following rapid credit growth over the last two years, the BM will closely supervise activities in the banking system and encourage banks to develop a stress testing framework. Close attention will be devoted to assessing liquidity conditions and the quality of loan portfolios. Finally, the authorities intend to take important steps to make the AML/CFT framework more effective in the near future.

\section{Improving the business environment, economic governance, and statistics}

\section{The government intends to implement a broad range of} measures to improve the business environment, improve economic governance, and transparency. While they largely fall outside of the core area of expertise of the Fund, they are important to stimulate the hoped-for response of the private sector in boosting economic activity. Among other things, the authorities are working with the Bank on implementing a vast range of fast-track measures to ease red tape, streamline the granting of business-related licenses, improve bankruptcy proceedings, and facilitate trading across borders. They also reiterated their commitment to implement their action plan to enhance transparency and accountability in the natural resources sector to become a full member of EITI within the envisaged timeframe of two years, i.e., by May 2011. Finally, based on Fund 
TA, the government will improve its statistical system, particularly improving data quality of the quarterly national accounts, consumer prices index, government finance statistics, and megaprojects.

\section{Program Monitoring}

38. Three changes were made to the quantitative program targets under the successor PSI compared to the expiring PSI/ESF program (MEFP Table 1). First, the ceiling on nonconcessional borrowing is modified to allow untied external borrowing at larger amounts compared to the previous limits that were virtually nil, so as to support the authorities' development objectives. Second, the reserve money target is to be met henceforth on an average basis, which in light of intra-month volatility should help the BM's ability to observe the target. And third, an indicative floor on priority spending, as defined in the authorities' poverty reduction strategy PARPA, has been introduced to ensure that the expansion in the authorities' public investment program does not impair expenditure on PARPA objectives, such as in the areas of health and education.

\section{Staff ApPRAisal}

39. The Mozambican authorities are to be commended for the successful implementation of their first three-year PSI. Notwithstanding a difficult external environment-first the food and oil price shock and then the global financial crisis- the authorities were able to keep the economy on course through appropriate fiscal and monetary policies. Their traditionally prudent macroeconomic policy mix provided them with the necessary room to flexibly respond to these exogenous shocks. The authorities also made significant headways in implementing their structural reform agenda, including in particular related to PFM, tax policy and administration, the monetary policy framework, and financial sector supervision. Overall, Mozambique fits the characteristics of a mature stabilizer well, with its strong economic growth, low inflation, comfortable external reserves, and sustainable debt.

40. Mozambique has shown remarkable resilience to the global crisis. Its economic performance in 2009 was stronger than expected, notwithstanding the decline in export proceeds and private capital inflows. The domestic economy held up well under the circumstances, as the authorities appropriately loosened fiscal and monetary policies to support economic activity. In particular, an accommodating monetary policy helped substitute foreign borrowing with domestic credit at a crucial time. This, together with the traditional difficulties in predicting cash demand in a country that is transitioning toward a banked economy, contributed to the BM exceeding the reserve money target for end-December 2009. This has resulted in the need for a waiver, which the staff supports, as the BM is committed to restraining monetary growth in 2010. A strong revenue performance-reaping the rewards of past efforts to strengthen tax administration - kept automatic stabilizers small and resulted in a lower-than-anticipated domestic primary deficit. With the improved economic outlook, the authorities' plans to unwind in 2010 the policy easing from last year is appropriate. 
41. The authorities' intention to raise economic growth to achieve their development objectives while safeguarding macroeconomic stability is welcome, though not without risks. Increasing growth outside the megaprojects in the natural resources sector requires removing identified bottlenecks so that the private sector can develop and play its intended role as an engine for growth. The authorities' focus is on developing infrastructure in the energy and transport sectors, which is of paramount importance in this vast country. But this is not a panacea, as the infrastructure investment needs to be complemented with targeted measures to improve the business environment, develop sectoral growth strategies, and foster regional trade integration. It also crucially hinges on the authorities' commitment to preserve one of Mozambique's strongest assets - its strong track record of macroeconomic stability and low debt vulnerabilities. And it requires putting in place a modern framework for investment planning and PPPs that would be backed by best practices in terms of financial management, accounting, and risk sharing with the private sector. Moving too forcefully with the intended investment push could erode the gains of prior years and risks leaving the country worse off down the road.

\section{The successor PSI aims to strike a balance between addressing Mozambique's} daunting development needs and preserving macroeconomic stability. The program accommodates a temporary increase in public investment, partially financed through nonconcessional external borrowing, while keeping domestic demand pressures in check. At the same time, the authorities would need to significantly improve their ability for economic decision making with respect to selecting investment projects and their financing options. The program's structural reform focus on debt management - including the development of a coherent debt strategy and the finalization of the authorities' first own DSA - and on investment planning aims to quickly bring the authorities up to speed in this regard. In addition, a continued strong implementation record of fiscal structural reforms in the areas of PFM and tax policy and administration will help shore up the program's fiscal policy stance. The authorities are also encouraged to continue their efforts to improve liquidity forecasting and management, which should help their preparations for possibly adopting an inflation targeting framework during the program period.

\section{Based on program performance to date and the authorities' commitment to} program implementation, staff recommends: (i) completion of the sixth PSI review and the second review under the ESF arrangement; (ii) the waiver for the nonobservance of the end-December $2009 \mathrm{AC} / \mathrm{PC}$ on reserve money, as corrective action is being taken; and (iii) approval of the proposed successor three-year PSI covering the period 2010-13. 
Table 1. Mozambique: Selected Economic and Financial Indicators, 2008-15

\begin{tabular}{|c|c|c|c|c|c|c|c|c|c|c|}
\hline & \multirow{2}{*}{$\begin{array}{r}2008 \\
\text { Act. }\end{array}$} & \multicolumn{2}{|c|}{2009} & \multicolumn{2}{|l|}{2010} & 2011 & 2012 & 2013 & \multirow{2}{*}{2014} & \multirow[t]{2}{*}{2015} \\
\hline & & Prog. & Proj. & EBS/09/327 & Proj. & \multicolumn{3}{|c|}{ Projections } & & \\
\hline & \multicolumn{10}{|c|}{ (Annual percentage change, unless otherwise indicated) } \\
\hline \multicolumn{11}{|l|}{ National income and prices } \\
\hline Nominal GDP (MT billion) & 240 & 260 & 263 & 300 & 306 & 348 & 396 & 451 & 514 & 585 \\
\hline Nominal GDP growth & 15.5 & 8.2 & 9.8 & 15.5 & 16.3 & 13.6 & 13.9 & 13.9 & 13.8 & 13.9 \\
\hline Real GDP growth & 6.7 & 4.5 & 6.3 & 5.4 & 6.5 & 7.5 & 7.6 & 7.9 & 7.8 & 7.8 \\
\hline GDP per capita (US\$) & 478 & 445 & 465 & 471 & 473 & 488 & 542 & 604 & 657 & 699 \\
\hline Consumer price index (annual average) & 10.3 & 3.5 & 3.3 & 9.5 & 9.3 & 5.6 & 5.6 & 5.6 & 5.6 & 5.6 \\
\hline Consumer price index (end of period) & 6.2 & 5.4 & 4.2 & 8.0 & 8.0 & 5.6 & 5.6 & 5.6 & 5.6 & 5.6 \\
\hline \multicolumn{11}{|l|}{ External sector } \\
\hline Merchandise exports & 10.0 & -26.5 & -30.2 & 9.8 & 12.7 & 27.2 & 8.1 & 6.6 & 8.9 & 9.3 \\
\hline Merchandise exports, excluding megaprojects & 41.1 & -22.3 & -26.8 & 4.3 & 4.5 & 2.7 & 3.8 & 4.9 & 6.2 & 6.6 \\
\hline Merchandise imports & 29.6 & -10.0 & -11.0 & 0.8 & 10.7 & 13.1 & 9.6 & 9.3 & 8.7 & 9.1 \\
\hline Merchandise imports, excluding megaprojects & 34.7 & -6.4 & -16.7 & -1.7 & 14.5 & 16.1 & 10.9 & 10.4 & 9.0 & 10.1 \\
\hline Terms of trade & -3.9 & -12.7 & -8.5 & 4.3 & 1.5 & 12.0 & 0.1 & 0.4 & -1.2 & -3.5 \\
\hline Nominal effective exchange rate (end of period) & 11.1 & $\ldots$ & -4.0 & $\ldots$ & $\ldots$ & $\ldots$ & $\ldots$ & $\ldots$ & $\ldots$ & $\ldots$ \\
\hline \multirow[t]{2}{*}{ Real effective exchange rate (end of period) } & 11.8 & $\ldots$ & -3.2 & $\ldots$ & $\ldots$ & $\cdots$ & $\ldots$ & $\cdots$ & $\ldots$ & $\ldots$ \\
\hline & \multicolumn{10}{|c|}{ (Annual percentage change, unless otherwise indicated) } \\
\hline \multicolumn{11}{|l|}{ Money and credit } \\
\hline Reserve money & 7.8 & 18.0 & 27.3 & 16.0 & 19.5 & 14.7 & 15.0 & 15.1 & 14.9 & 15.0 \\
\hline M2 & 26.0 & 28.6 & 34.6 & 20.4 & 22.6 & 21.6 & 17.2 & 16.9 & 16.0 & 15.3 \\
\hline M3 (Broad Money) & 20.3 & 25.6 & 32.6 & 18.3 & 21.1 & 23.1 & 16.6 & 16.3 & 15.4 & 14.7 \\
\hline \multirow[t]{2}{*}{ Credit to the economy } & 45.9 & 44.6 & 58.6 & 17.8 & 19.1 & 14.0 & 14.9 & 15.8 & 15.7 & 15.8 \\
\hline & \multicolumn{10}{|c|}{ (Percent of GDP) } \\
\hline \multicolumn{11}{|l|}{ Investment and saving } \\
\hline Gross domestic investment & 15.7 & 15.9 & 21.0 & 19.7 & 25.2 & 26.0 & 26.9 & 27.2 & 27.3 & 27.3 \\
\hline Government & 11.6 & 11.7 & 13.1 & 13.6 & 13.9 & 14.3 & 14.6 & 14.6 & 14.8 & 15.0 \\
\hline Other sectors & 4.1 & 4.1 & 7.9 & 6.1 & 11.3 & 11.8 & 12.4 & 12.6 & 12.5 & 12.3 \\
\hline Gross domestic savings (excluding grants) & -4.0 & -1.9 & 2.0 & 0.4 & 4.6 & 5.5 & 5.9 & 6.3 & 6.8 & 7.1 \\
\hline Government & 0.3 & -1.3 & -0.4 & -0.3 & 1.2 & 1.2 & 1.5 & 1.9 & 2.1 & 2.4 \\
\hline Other sectors & -4.3 & -0.6 & 2.5 & 0.7 & 3.4 & 4.4 & 4.4 & 4.5 & 4.7 & 4.7 \\
\hline External current account, before grants & -19.7 & -17.8 & -18.9 & -19.3 & -20.6 & -20.5 & -21.0 & -20.9 & -20.4 & -20.2 \\
\hline External current account, after grants & -11.9 & -11.0 & -11.9 & -11.5 & -13.6 & -12.8 & -13.5 & -13.4 & -13.0 & -12.8 \\
\hline \multicolumn{11}{|l|}{ Government budget } \\
\hline Total revenue & 16.0 & 16.4 & 17.8 & 16.7 & 18.4 & 18.7 & 19.2 & 19.7 & 20.0 & 20.3 \\
\hline Total expenditure and net lending & 27.9 & 30.1 & 32.9 & 31.4 & 31.9 & 35.4 & 35.2 & 35.0 & 34.5 & 34.6 \\
\hline Overall balance, before grants & -11.8 & -13.7 & -15.2 & -14.7 & -13.5 & -16.7 & -16.1 & -15.3 & -14.5 & -14.2 \\
\hline Total grants & 9.4 & 9.3 & 9.6 & 10.8 & 8.8 & 9.4 & 9.3 & 9.2 & 9.2 & 9.2 \\
\hline Overall balance, after grants & -2.3 & -4.3 & -5.6 & -3.9 & -4.7 & -7.2 & -6.8 & -6.1 & -5.3 & -5.1 \\
\hline Domestic primary balance, before grants & -3.2 & -5.3 & -4.4 & -5.1 & -4.2 & -4.6 & -4.4 & -4.0 & -3.8 & -3.7 \\
\hline External financing (incl. debt relief) & 4.0 & 3.1 & 5.1 & 2.1 & 4.3 & 6.3 & 5.9 & 5.4 & 4.5 & 4.3 \\
\hline Net domestic financing & -1.7 & 0.8 & 0.3 & 1.8 & 0.3 & 0.9 & 0.9 & 0.7 & 0.8 & 0.8 \\
\hline Privatization & 0.0 & 0.4 & 0.2 & 0.0 & 0.1 & 0.0 & 0.0 & 0.0 & 0.0 & 0.0 \\
\hline & & & & US\$ millions, & nless oth & rwise indi & cated) & & & \\
\hline External current account, before grants & $-1,958$ & $-1,677$ & $-1,859$ & $-1,959$ & $-2,104$ & $-2,204$ & $-2,560$ & $-2,889$ & $-3,138$ & $-3,375$ \\
\hline External current account, after grants & $-1,179$ & $-1,034$ & $-1,171$ & $-1,167$ & $-1,391$ & $-1,380$ & $-1,646$ & $-1,858$ & $-2,001$ & $-2,140$ \\
\hline Overall balance of payments & 120 & 114 & 197 & -48 & 100 & 405 & 431 & 323 & 231 & 236 \\
\hline Net international reserves (end of period) ${ }^{1}$ & 1,644 & 1,758 & 1,834 & 1,711 & 1,930 & 2,334 & 2,766 & 3,088 & 3,320 & 3,556 \\
\hline Gross international reserves (end of period) ${ }^{1}$ & 1,660 & 1,929 & 2,012 & 1,904 & 2,128 & 2,530 & 2,959 & 3,278 & 3,476 & 3,652 \\
\hline Months of projected imports of goods and nonfactor services & 4.6 & 5.4 & 5.1 & 5.0 & 4.9 & 5.3 & 5.6 & 5.7 & 5.5 & 5.3 \\
\hline
\end{tabular}


Table 2. Mozambique: Government Finances, 2008-15

(MT Billions)

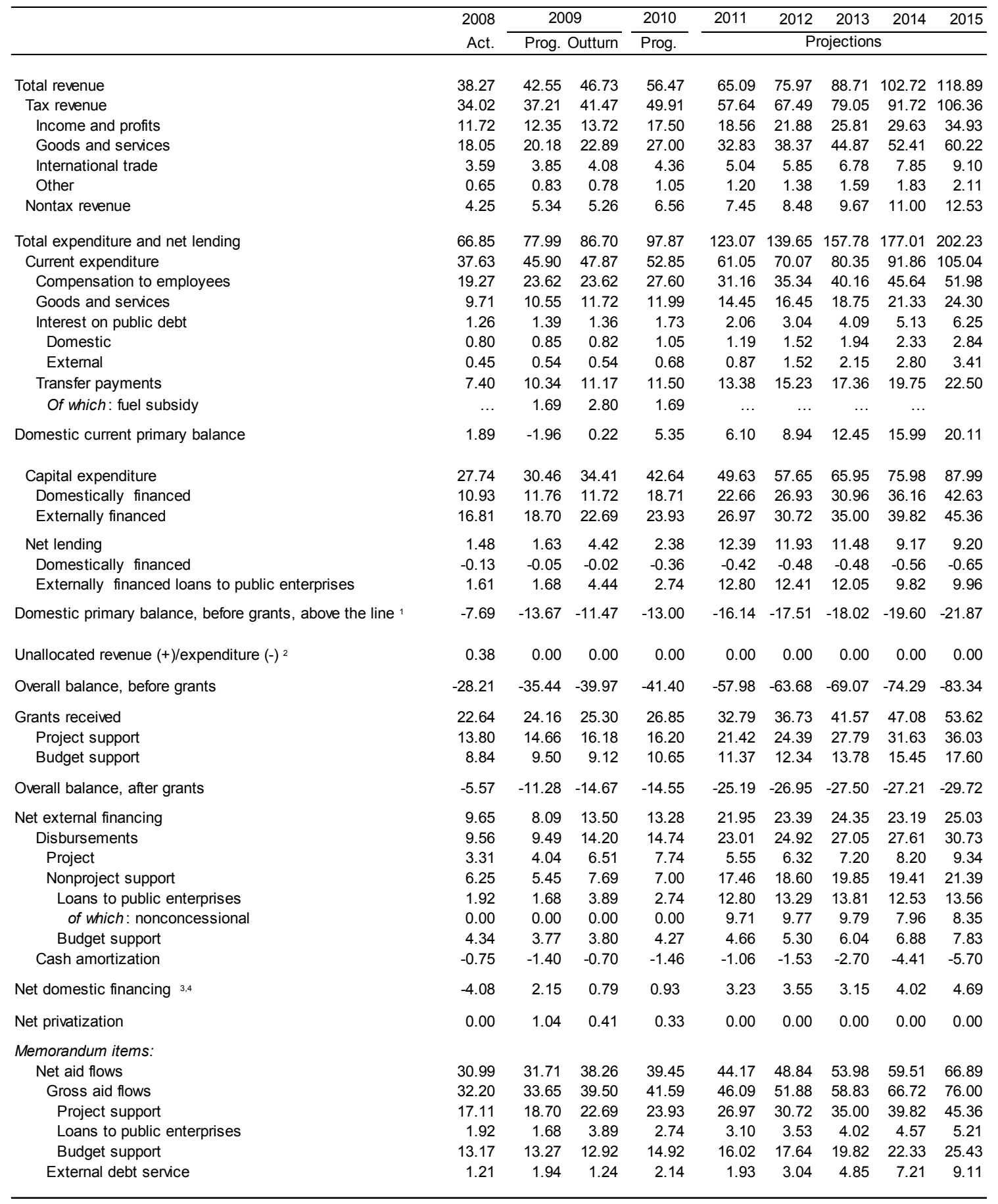

Sources: Mozambican authorities; and IMF staff estimates and projections.

${ }^{1}$ Revenue minus noninterest current expenditure minus locally financed capital expenditure and locally financed net lending.

2 Residual discrepancy between identified sources and uses of funds. For 2009, reflects expenditure initiated outside the PFM IT

regularized later.

3 Excludes recapitilization bonds issued to the Bank of Mozambique.

${ }_{4}^{4}$ A World Bank disbursement of US $\$ 80$ (US\$110) million budget support designated for 2009 (2010) was advanced to 2008 (2009). 
Table 3. Mozambique: Government Finances, 2008-15 (Percent of GDP)

\begin{tabular}{|c|c|c|c|c|c|c|c|c|c|}
\hline & \multirow{2}{*}{$\begin{array}{l}2008 \\
\text { Act. }\end{array}$} & \multicolumn{2}{|c|}{2009} & \multirow{2}{*}{$\begin{array}{c}2010 \\
\text { Prog. }\end{array}$} & \multirow[t]{2}{*}{2011} & 2012 & 2013 & \multirow[t]{2}{*}{2014} & \multirow[t]{2}{*}{2015} \\
\hline & & Prog. & Est. & & & \multicolumn{2}{|c|}{ Projections } & & \\
\hline Total revenue & 16.0 & 16.4 & 17.8 & 18.4 & 18.7 & 19.2 & 19.7 & 20.0 & 20.3 \\
\hline Tax revenue & 14.2 & 14.3 & 15.8 & 16.3 & 16.6 & 17.0 & 17.5 & 17.9 & 18.2 \\
\hline Nontax revenue & 1.8 & 2.1 & 2.0 & 2.1 & 2.1 & 2.1 & 2.1 & 2.1 & 2.1 \\
\hline Total expenditure and net lending & 27.9 & 30.1 & 32.9 & 32.0 & 35.4 & 35.2 & 35.0 & 34.5 & 34.6 \\
\hline Current expenditure & 15.7 & 17.7 & 18.2 & 17.3 & 17.5 & 17.7 & 17.8 & 17.9 & 18.0 \\
\hline Compensation to employees & 8.0 & 9.1 & 9.0 & 9.0 & 9.0 & 8.9 & 8.9 & 8.9 & 8.9 \\
\hline Goods and services & 4.0 & 4.1 & 4.5 & 3.9 & 4.2 & 4.2 & 4.2 & 4.2 & 4.2 \\
\hline Interest on public debt & 0.5 & 0.5 & 0.5 & 0.6 & 0.6 & 0.8 & 0.9 & 1.0 & 1.1 \\
\hline Transfer payments & 3.1 & 4.0 & 4.2 & 3.8 & 3.8 & 3.8 & 3.8 & 3.8 & 3.8 \\
\hline Of which: fuel subsidy & $\ldots$ & 0.6 & 1.1 & 0.6 & $\ldots$ & $\ldots$ & $\ldots$ & $\ldots$ & \\
\hline Domestic current primary balance & 0.8 & -0.8 & 0.1 & 1.7 & 1.8 & 2.3 & 2.8 & 3.1 & 3.4 \\
\hline Capital expenditure & 11.6 & 11.7 & 13.1 & 13.9 & 14.3 & 14.6 & 14.6 & 14.8 & 15.0 \\
\hline Domestically financed & 4.6 & 4.5 & 4.5 & 6.1 & 6.5 & 6.8 & 6.9 & 7.0 & 7.3 \\
\hline Externally financed & 7.0 & 7.2 & 8.6 & 7.8 & 7.8 & 7.8 & 7.8 & 7.8 & 7.8 \\
\hline Net lending & 0.6 & 0.6 & 1.7 & 0.8 & 3.6 & 3.0 & 2.5 & 1.8 & 1.6 \\
\hline Domestically financed & -0.1 & 0.0 & 0.0 & -0.1 & -0.1 & -0.1 & -0.1 & -0.1 & -0.1 \\
\hline Externally financed loans to public enterprises & 0.7 & 0.6 & 1.7 & 0.9 & 3.7 & 3.1 & 2.7 & 1.9 & 1.7 \\
\hline Domestic primary balance, before grants, above the line ${ }^{1}$ & -3.2 & -5.3 & -4.4 & -4.2 & -4.6 & -4.4 & -4.0 & -3.8 & -3.7 \\
\hline Unallocated revenue $(+)$ /expenditure $(-)^{2}$ & 0.2 & 0.0 & 0.0 & 0.0 & 0.0 & 0.0 & 0.0 & 0.0 & 0.0 \\
\hline Domestic primary balance & -3.9 & -5.3 & -4.4 & -4.2 & -4.6 & -4.4 & -4.0 & -3.8 & -3.7 \\
\hline Overall balance, before grants & -11.8 & -13.7 & -15.2 & -13.5 & -16.7 & -16.1 & -15.3 & -14.5 & -14.2 \\
\hline Grants received & 9.4 & 9.3 & 9.6 & 8.8 & 9.4 & 9.3 & 9.2 & 9.2 & 9.2 \\
\hline Project & 5.8 & 5.7 & 6.1 & 5.3 & 6.2 & 6.2 & 6.2 & 6.2 & 6.2 \\
\hline Nonproject & 3.7 & 3.7 & 3.5 & 3.5 & 3.3 & 3.1 & 3.1 & 3.0 & 3.0 \\
\hline Overall balance, after grants & -2.3 & -4.3 & -5.6 & -4.7 & -7.2 & -6.8 & -6.1 & -5.3 & -5.1 \\
\hline Net external financing & 4.0 & 3.1 & 5.1 & 4.3 & 6.3 & 5.9 & 5.4 & 4.5 & 4.3 \\
\hline Disbursements & 4.0 & 3.7 & 5.4 & 4.8 & 6.6 & 6.3 & 6.0 & 5.4 & 5.3 \\
\hline Project & 1.4 & 1.6 & 2.5 & 2.5 & 1.6 & 1.6 & 1.6 & 1.6 & 1.6 \\
\hline Nonproject support & 2.6 & 2.1 & 2.9 & 2.3 & 5.0 & 4.7 & 4.4 & 3.8 & 3.7 \\
\hline Loans to public enterprises & 0.8 & 0.6 & 1.5 & 0.9 & 3.7 & 3.4 & 3.1 & 2.4 & 2.3 \\
\hline of which: nonconcessional & 0.0 & 0.0 & 0.0 & 0.0 & 2.8 & 2.5 & 2.2 & 1.6 & 1.4 \\
\hline Budget support & 1.8 & 1.5 & 1.4 & 1.4 & 1.3 & 1.3 & 1.3 & 1.3 & 1.3 \\
\hline Cash amortization & -0.3 & -0.5 & -0.3 & -0.5 & -0.3 & -0.4 & -0.6 & -0.9 & -1.0 \\
\hline Net domestic financing ${ }^{3,4}$ & -1.7 & 0.8 & 0.3 & 0.3 & 0.9 & 0.9 & 0.7 & 0.8 & 0.8 \\
\hline Net privatization & 0.0 & 0.4 & 0.2 & 0.1 & 0.0 & 0.0 & 0.0 & 0.0 & 0.0 \\
\hline \multicolumn{10}{|l|}{ Memorandum items: } \\
\hline Net aid flows & 12.9 & 12.2 & 14.5 & 12.9 & 12.7 & 12.3 & 12.0 & 11.6 & 11.4 \\
\hline Gross aid flows & 13.4 & 13.0 & 15.0 & 13.6 & 13.2 & 13.1 & 13.0 & 13.0 & 13.0 \\
\hline Budget support & 5.5 & 5.1 & 4.9 & 4.9 & 4.6 & 4.5 & 4.4 & 4.3 & 4.3 \\
\hline Project support & 7.1 & 7.2 & 8.6 & 7.8 & 7.8 & 7.8 & 7.8 & 7.8 & 7.8 \\
\hline Loans to public enterprises & 0.8 & 0.6 & 1.5 & 0.9 & 0.9 & 0.9 & 0.9 & 0.9 & 0.9 \\
\hline External debt service & 0.5 & 0.7 & 0.5 & 0.7 & 0.6 & 0.8 & 1.1 & 1.4 & 1.6 \\
\hline
\end{tabular}

Sources: Mozambican authorities; and IMF staff estimates and projections.

$1 /$ Includes costs of monetary policy transferred to the Bank

${ }^{1}$ Revenue minus noninterest current expenditure, financed capital expenditure, and locally financed net lending.

${ }_{2}^{2}$ Residual discrepancy between identified sources and uses of funds.

${ }^{3}$ Excludes recapitilization bonds issued to the Bank of Mozambique.

${ }^{4} \mathrm{~A}$ World Bank disbursement of US $\$ 80$ (US\$110) million budget support designated for 2009 (2010) was advanced to 2008 (2009). 
Table 4. Mozambique: Monetary Survey, Quarterly, 2008-10 1

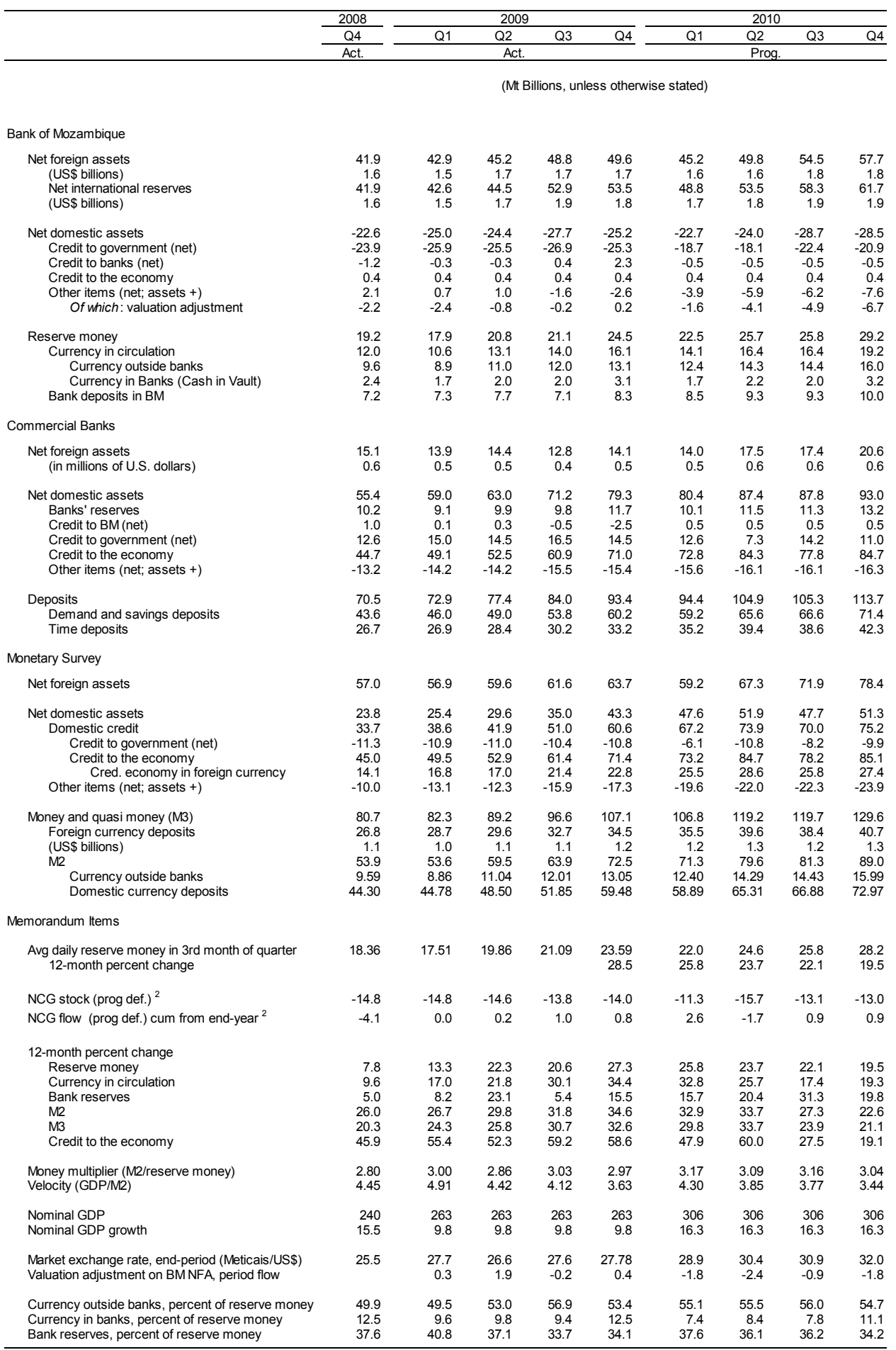

Sources: Bank of Mozambique; and IMF staff estimates and projections.

${ }^{1}$ Includes disbursements of Fund resources under the ESF and the August 2009 SDR allocation

${ }^{2}$ As defined in the TMU, this equals the NCG in the monetary survey excluding Moatize deposits, earmarked donor funds, and bonds issued to capitalize the BM.

${ }^{3}$ As defined in the TMU, this equals the NIR in the BM accounts evaluated at the program exchange rates versus the U.S. dollar specified in Table 1 of the TMU. 
Table 5. Mozambique: Balance of Payments, 2008-15

(Millions of U.S. dollars, unless otherwise specified)

\begin{tabular}{|c|c|c|c|c|c|c|c|c|c|}
\hline & \multirow{2}{*}{$\frac{2008}{\text { Actual }}$} & \multicolumn{2}{|c|}{2009} & \multirow{2}{*}{$\frac{2010}{\text { Proj. }}$} & 2011 & 2012 & 2013 & 2014 & 2015 \\
\hline & & Prog. & Act. & & \multicolumn{5}{|c|}{ Projections } \\
\hline Current account balance & $-1,179$ & $-1,034$ & $-1,171$ & $-1,391$ & $-1,380$ & $-1,646$ & $-1,858$ & $-2,001$ & $-2,140$ \\
\hline Trade balance for goods & -990 & $-1,328$ & $-1,390$ & $-1,500$ & $-1,403$ & $-1,575$ & $-1,799$ & $-1,949$ & $-2,121$ \\
\hline Of which: Megaprojects & 1,150 & 802 & 474 & 693 & 1,226 & 1,386 & 1,506 & 1,673 & 1,892 \\
\hline Exports, f.o.b. & 2,653 & 1,951 & 1,853 & 2,089 & 2,656 & 2,872 & 3,062 & 3,334 & 3,645 \\
\hline Of which: Megaproject exports & 1,851 & 1,328 & 1,265 & 1,474 & 2,026 & 2,217 & 2,375 & 2,605 & 2,868 \\
\hline Imports, f.o.b. & $-3,643$ & $-3,279$ & $-3,243$ & $-3,589$ & $-4,059$ & $-4,447$ & $-4,861$ & $-5,283$ & $-5,766$ \\
\hline Of which: Megaproject imports & -702 & -526 & -791 & -782 & -800 & -832 & -869 & -932 & -976 \\
\hline Trade balance for services & -410 & -411 & -450 & -451 & -495 & -561 & -637 & -707 & -768 \\
\hline Income balance & -631 & -63 & -95 & -233 & -390 & -520 & -561 & -602 & -617 \\
\hline Of which: Dividend payments by megaprojects & -492 & -23 & -17 & -220 & -369 & -477 & -496 & -518 & -518 \\
\hline Current transfers balance & 852 & 768 & 764 & 793 & 908 & 1,010 & 1,139 & 1,257 & 1,365 \\
\hline Of which: External grants & 778 & 643 & 687 & 713 & 824 & 914 & 1,031 & 1,137 & 1,235 \\
\hline Capital and financial account balance & 1,188 & 1,188 & 1,439 & 1,491 & 1,785 & 2,077 & 2,181 & 2,232 & 2,376 \\
\hline Capital account balance & 420 & 432 & 422 & 371 & 391 & 442 & 503 & 558 & 606 \\
\hline Financial account balance & 768 & 756 & 1,016 & 1,119 & 1,394 & 1,635 & 1,678 & 1,674 & 1,770 \\
\hline Net foreign direct investment & 587 & 532 & 878 & 917 & 732 & 748 & 802 & 908 & 1,016 \\
\hline Net foreign borrowing by the general government & 342 & 354 & 434 & 583 & 836 & 865 & 881 & 817 & 771 \\
\hline Net foreign borrowing by the nonfinancial private sector & -97 & -247 & -456 & -203 & -37 & 227 & 227 & 207 & 264 \\
\hline Other $^{1}$ & -64 & 116 & 160 & -177 & -137 & -205 & -233 & -258 & -280 \\
\hline Of which: Special drawing rights & 0 & 169 & 170 & 0 & 0 & 0 & 0 & 0 & 0 \\
\hline Net errors and omissions & 112 & -40 & -70 & 0 & 0 & 0 & 0 & 0 & 0 \\
\hline Overall balance & 120 & 114 & 197 & 100 & 405 & 431 & 323 & 231 & 236 \\
\hline External financing & -120 & -114 & -197 & -100 & -405 & -431 & -323 & -231 & -236 \\
\hline Reserve assets ${ }^{1,2}$ & -140 & -269 & -352 & -120 & -403 & -428 & -320 & -198 & -175 \\
\hline Net use of Fund credit ${ }^{2}$ & 0 & 155 & 152 & 20 & -2 & -3 & -3 & -34 & -61 \\
\hline Exceptional financing & 19 & 1 & 2 & 0 & 0 & 0 & 0 & 0 & 0 \\
\hline \multicolumn{10}{|l|}{ Memorandum items: } \\
\hline \multicolumn{10}{|l|}{ Effective exchange rate indexes (percent change) } \\
\hline Nominal effective exchange rate & 11.1 & $\ldots$ & -4.0 & $\ldots$ & $\ldots$ & $\ldots$ & $\ldots$ & $\ldots$ & $\ldots$ \\
\hline Real effective exchange rate & 11.8 & $\ldots$ & -3.2 & $\ldots$ & $\cdots$ & $\ldots$ & $\ldots$ & $\ldots$ & $\ldots$ \\
\hline Terms of trade index (percent change) & -3.9 & -12.7 & -8.5 & 1.5 & 12.0 & 0.1 & 0.4 & -1.2 & -3.5 \\
\hline International aluminum price & -2.3 & -37.9 & -35.8 & 14.8 & 10.5 & 9.5 & 4.3 & 4.2 & 0.0 \\
\hline International food price index & 23.4 & -14.9 & -14.7 & 2.7 & -0.4 & 0.4 & 0.7 & 0.4 & 0.2 \\
\hline International fuel price index & 40.1 & -37.2 & -36.4 & 19.9 & 7.5 & 3.3 & 2.1 & 2.5 & 2.4 \\
\hline Current account balance (percent of GDP) & -11.9 & -11.0 & -11.9 & -13.6 & -12.8 & -13.5 & -13.4 & -13.0 & -12.8 \\
\hline Excluding external grants & -19.7 & -17.8 & -18.9 & -20.6 & -20.5 & -21.0 & -20.9 & -20.4 & -20.2 \\
\hline Gross aid inflows (percent of GDP) & 14.3 & 13.8 & 16.0 & 14.8 & 14.5 & 14.2 & 14.0 & 13.9 & 13.8 \\
\hline Of which: To central government & 13.4 & 13.8 & 15.0 & 13.5 & 13.2 & 13.1 & 13.0 & 13.0 & 13.0 \\
\hline Budget support & 5.5 & 5.3 & 4.9 & 4.9 & 4.6 & 4.5 & 4.4 & 4.3 & 4.3 \\
\hline Project support & 7.1 & 7.5 & 8.6 & 7.8 & 7.8 & 7.8 & 7.8 & 7.8 & 7.8 \\
\hline Onlending & 0.8 & 1.0 & 1.5 & 0.9 & 0.9 & 0.9 & 0.9 & 0.9 & 0.9 \\
\hline Net foreign assets & 1,642 & 1,610 & 1,701 & 1,800 & 2,205 & 2,636 & 2,959 & 3,191 & 3,427 \\
\hline Net international reserves ${ }^{1,2}$ & 1,644 & 1,758 & 1,834 & 1,930 & 2,334 & 2,766 & 3,088 & 3,320 & 3,556 \\
\hline Gross international reserves 1,2 & 1,660 & 1,929 & 2,012 & 2,128 & 2,530 & 2,959 & 3,278 & 3,476 & 3,652 \\
\hline Months of projected imports of goods and nonfactor services & 4.6 & 5.4 & 5.1 & 4.9 & 5.3 & 5.6 & 5.7 & 5.5 & 5.3 \\
\hline Months of current imports of goods and nonfactor services & 4.3 & 5.4 & 5.6 & 5.4 & 5.8 & 6.2 & 6.2 & 6.0 & 5.8 \\
\hline
\end{tabular}

Sources: Data from Government of Mozambique and projections by IMF staff.

'Accounts for disbursement of an SDR allocation of SDR 108.8 million in 2009 Q3 above the line under other investment liabilities of the monetary authorities, and below the line as an increase in reserve assets.

${ }^{2}$ Based on an ESF-HAC arrangement of SDR 113.6 million (100 percent of quota) to be disbursed in three tranches: SDR 85.2 million (75 percent of quota) already disbursed follow ing completion of the fourth PSI review and approval of the ESF arrangement; SDR 14.2 million (12.5 percent of quota) already disbursed follow ing completion of the fifth PSI and first ESF review; and SDR 14.2 million (12.5 percent of quota) to be disbursed upon completion of the sixth PSI and second ESF review. 
Table 6. Mozambique: Indicators of Capacity to Repay the Fund

\begin{tabular}{|c|c|c|c|c|c|c|c|c|c|c|c|c|c|}
\hline & \multicolumn{11}{|c|}{ Projection } & \multirow[b]{2}{*}{2020} & \multirow[b]{2}{*}{ Total } \\
\hline & 2009 & 2010 & 2011 & 2012 & 2013 & 2014 & 2015 & 2016 & 2017 & 2018 & 2019 & & \\
\hline Fund obligations based on existing credit & 0.2 & 1.5 & 2.3 & 3.0 & 3.0 & 33.5 & 32.3 & 31.5 & 30.8 & 30.8 & 0.0 & 0.0 & \\
\hline Principal (millions of SDRs) & 0.2 & 1.0 & 1.5 & 1.9 & 1.9 & 21.7 & 20.9 & 20.4 & 19.9 & 19.9 & 0.0 & 0.0 & 109.1 \\
\hline Charges and interest (millions of SDRs) & 0.0 & 0.0 & 0.0 & 0.3 & 0.3 & 0.3 & 0.2 & 0.2 & 0.1 & 0.1 & 0.0 & 0.0 & 1.4 \\
\hline \multicolumn{14}{|l|}{ Fund obligations based on existing and prospective credit ${ }^{1}$} \\
\hline Principal (millions of SDRs) & 0.2 & 1.0 & 1.5 & 1.9 & 1.9 & 21.7 & 39.3 & 43.1 & 42.6 & 42.6 & 22.7 & 4.3 & 222.7 \\
\hline Charges and interest (millions of SDRs) & 0.2 & 0.5 & 0.6 & 0.8 & 0.8 & 0.8 & 0.7 & 0.6 & 0.4 & 0.2 & 0.1 & 0.0 & 5.8 \\
\hline \multicolumn{14}{|l|}{ Total obligations based on existing and prospective credit ${ }^{1}$} \\
\hline In millions of SDRs & 0.4 & 1.5 & 2.0 & 2.8 & 2.8 & 22.5 & 40.0 & 43.6 & 43.0 & 42.8 & 22.8 & 4.3 & $\ldots$ \\
\hline In millions of U.S. dollars & 0.6 & 2.3 & 3.1 & 4.3 & 4.3 & 34.8 & 62.0 & 67.6 & 66.5 & 66.3 & 35.2 & 6.6 & $\ldots$ \\
\hline In percent of exports of goods and services & 0.0 & 0.1 & 0.1 & 0.1 & 0.1 & 0.8 & 1.3 & 1.3 & 1.1 & 1.0 & 0.5 & 0.1 & $\ldots$ \\
\hline In percent of debt service & 1.3 & 3.3 & 4.2 & 3.5 & 2.2 & 12.7 & 17.1 & 16.2 & 14.6 & 13.7 & 6.8 & 1.3 & $\ldots$ \\
\hline In percent of GDP & 0.0 & 0.0 & 0.0 & 0.0 & 0.0 & 0.2 & 0.4 & 0.4 & 0.3 & 0.3 & 0.1 & 0.0 & $\ldots$ \\
\hline In percent of gross international reserves & 0.0 & 0.1 & 0.1 & 0.1 & 0.1 & 1.0 & 1.7 & 1.8 & 1.8 & 1.6 & 0.8 & 0.1 & $\ldots$ \\
\hline In percent of quota & 0.4 & 1.3 & 1.8 & 2.5 & 2.4 & 19.8 & 35.2 & 38.4 & 37.9 & 37.7 & 20.0 & 3.8 & $\ldots$ \\
\hline \multicolumn{14}{|l|}{ Outstanding Fund credit } \\
\hline In millions of SDRs & 109.1 & 123.2 & 122.2 & 120.8 & 118.8 & 116.9 & 96.6 & 72.9 & 49.7 & 27.0 & 4.3 & 0.0 & $\ldots$ \\
\hline In millions of U.S. dollars & 168.4 & 190.9 & 188.9 & 186.7 & 183.8 & 180.8 & 149.5 & 112.8 & 76.9 & 41.8 & 6.6 & 0.0 & $\ldots$ \\
\hline In percent of exports of goods and services & 6.8 & 7.0 & 5.7 & 5.1 & 4.7 & 4.2 & 3.2 & 2.2 & 1.3 & 0.6 & 0.1 & 0.0 & $\ldots$ \\
\hline In percent of debt service & 342.4 & 265.3 & 251.2 & 151.2 & 95.5 & 66.2 & 41.4 & 27.1 & 16.9 & 8.6 & 1.3 & 0.0 & $\ldots$ \\
\hline In percent of GDP & 1.7 & 1.9 & 1.8 & 1.5 & 1.3 & 1.2 & 0.9 & 0.6 & 0.4 & 0.2 & 0.0 & 0.0 & $\ldots$ \\
\hline In percent of gross international reserves & 8.4 & 9.0 & 7.5 & 6.3 & 5.6 & 5.2 & 4.1 & 3.1 & 2.0 & 1.0 & 0.1 & 0.0 & $\ldots$ \\
\hline In percent of quota & 96.1 & 108.4 & 107.6 & 106.3 & 104.6 & 102.9 & 85.0 & 64.2 & 43.8 & 23.8 & 3.8 & 0.0 & $\ldots$ \\
\hline Net use of Fund credit (millions of SDRs) & 85.0 & 27.4 & -1.5 & -1.9 & -1.9 & -21.7 & -39.3 & -43.1 & -42.6 & -42.6 & -22.7 & -4.3 & -109.1 \\
\hline Disbursements 1 & 85.2 & 28.4 & 0.0 & 0.0 & 0.0 & 0.0 & 0.0 & 0.0 & 0.0 & 0.0 & 0.0 & 0.0 & 113.6 \\
\hline Repayments & 0.2 & 1.0 & 1.5 & 1.9 & 1.9 & 21.7 & 39.3 & 43.1 & 42.6 & 42.6 & 22.7 & 4.3 & 222.7 \\
\hline \multicolumn{14}{|l|}{ Memorandum items: } \\
\hline Nominal GDP (millions of U.S. dollars) & 9831 & 10212 & 10750 & 12169 & 13830 & 15353 & 16670 & 18326 & 20240 & 22352 & 24675 & 27244 & $\ldots$ \\
\hline Exports of goods and nonfactor services (millions of U.S. dollars) & 2464 & 2741 & 3322 & 3626 & 3919 & 4285 & 4678 & 5232 & 5926 & 6696 & 7431 & 8218 & $\ldots$ \\
\hline External PPG debt service (millions of U.S. dollars) & 49 & 72 & 75 & 124 & 193 & 273 & 362 & 416 & 455 & 484 & 522 & 526 & $\ldots$ \\
\hline Gross international reserves (millions of U.S. dollars) 1, $^{2}$ & 2012 & 2128 & 2530 & 2959 & 3278 & 3476 & 3652 & 3659 & 3789 & 4130 & 4637 & 5411 & $\ldots$ \\
\hline Quota (millions of SDRs) & 113.6 & 113.6 & 113.6 & 113.6 & 113.6 & 113.6 & 113.6 & 113.6 & 113.6 & 113.6 & 113.6 & 113.6 & $\ldots$ \\
\hline SDR exchange rate (SDR/USD) & 0.65 & 0.65 & 0.65 & 0.65 & 0.65 & 0.65 & 0.65 & 0.65 & 0.65 & 0.65 & 0.65 & 0.65 & $\ldots$ \\
\hline
\end{tabular}

Sources: Data from Government of Mozambique and projections by IMF staff.

${ }^{1}$ Based on an ESF-HAC arrangement of SDR 113.6 million (100 percent of quota) to be disbursed in three tranches: SDR 85.2 million (75 percent of quota) already disbursed follow ing completion of the fourth PSI review and approval of the ESF arrangement; SDR 14.2 million (12.5 percent of quota) to be disbursed upon completion of the fifth PSI and first ESF review ; and SDR 14.2 million (12.5 percent of quota) to be disbursed upon completion of the sixth PSI and second ESF review.

${ }^{2}$ Accounts for disbursement of an SDR allocation of SDR 108.8 million in 2009Q3. The projected interest obligations do not incorporate the expected temporary interest relief and new structure of interest rates. 
Table 7. Mozambique: Financial Soundness Indicators for Banking Sector, 2001-09 (Percent unless otherwise indicated)

\begin{tabular}{|c|c|c|c|c|c|c|c|c|c|c|c|c|}
\hline & 2001 & 2002 & 2003 & 2004 & 2005 & 2006 & 2007 & 2008 & Mar-09 & Jun-09 & Sep-09 & Dec-09 \\
\hline \multicolumn{13}{|l|}{ Capital adequacy } \\
\hline Regulatory capital to risk-weighted assets & 5.5 & 14.0 & 17.0 & 18.7 & 16.0 & 12.5 & 14.2 & 13.9 & 17.0 & 18.1 & 16.6 & 15.1 \\
\hline Regulatory Tier I capital to risk-weighted assets & 6.0 & 12.0 & 14.7 & 16.0 & 13.6 & 10.7 & 12.3 & 12.4 & 14.9 & 16.2 & 14.3 & 13.0 \\
\hline Capital (net worth) to assets & 8.2 & 9.4 & 9.0 & 9.5 & 8.0 & 6.1 & 6.4 & 6.7 & 8.2 & 8.1 & 8.4 & 7.7 \\
\hline \multicolumn{13}{|l|}{ Asset composition and quality } \\
\hline \multicolumn{13}{|l|}{ Sectoral distribution of loans to total loans } \\
\hline Agriculture & 18.0 & 15.0 & 12.7 & 9.5 & 8.5 & 6.4 & 9.4 & 8.1 & 7.7 & 8.0 & 6.9 & 7.0 \\
\hline Industry & 25.0 & 22.0 & 16.9 & 11.9 & 16.8 & 22.2 & 19.5 & 16.7 & 21.8 & 19.3 & 17.7 & 15.4 \\
\hline Construction & 4.0 & 4.0 & 5.2 & 3.4 & 4.1 & 5.6 & 5.7 & 4.2 & 4.7 & 5.1 & 4.9 & 6.4 \\
\hline Commerce & 20.0 & 17.0 & 18.1 & 21.3 & 27.4 & 27.4 & 24.4 & 25.6 & 24.7 & 22.9 & 19.6 & 23.4 \\
\hline Transportation and communication & 7.0 & 5.0 & 7.1 & 7.2 & 5.8 & 6.2 & 12.2 & 11.2 & 12.4 & 11.6 & 13.8 & 12.2 \\
\hline Other & 27.0 & 36.0 & 37.1 & 36.2 & 35.1 & 32.3 & 28.7 & 34.2 & 28.7 & 28.5 & 37.1 & 35.7 \\
\hline of which: Private $1 /$ & & & 7.6 & 12.1 & 13.0 & 13.5 & 14.4 & 19.9 & 17.3 & 18.1 & 12.5 & 16.7 \\
\hline Housing & & & 7.1 & 8.2 & 4.2 & 4.1 & 3.7 & 3.7 & 3.7 & 3.5 & 2.8 & 2.9 \\
\hline Diverse $2 /$ & & & 22.4 & 15.9 & 17.8 & 14.7 & 10.6 & 10.0 & 7.2 & 6.9 & 14.8 & 15.9 \\
\hline Foreign exchange loans to total loans & 64.7 & 69.9 & 70.8 & 67.3 & 63.9 & 45.0 & 31.5 & 40.1 & 36.1 & 33.1 & 36.2 & 32.4 \\
\hline Nonperforming loans to gross loans $3 /$ & 23.4 & 22.0 & 14.4 & 6.4 & 3.8 & 3.3 & 0.9 & 2.0 & 2.0 & 2.2 & 2.0 & 2.0 \\
\hline Nonperforming loans net of provisions to capital $3 /$ & 11.0 & 9.4 & 7.9 & 1.7 & 0.9 & 2.2 & 15.5 & 12.2 & 11.0 & 5.5 & 5.3 & 5.3 \\
\hline \multicolumn{13}{|l|}{ Earnings and profitability } \\
\hline Return on assets & 0.1 & 1.6 & 1.2 & 1.4 & 1.8 & 3.5 & 1.9 & 3.5 & 0.9 & 1.6 & 3.1 & 3.0 \\
\hline Return on equity & 3.5 & 22.1 & 16.3 & 18.7 & 27.4 & 55.4 & 25.1 & 40.7 & 1.8 & 18.1 & 37.0 & 36.6 \\
\hline Interest margin to gross income & 10.2 & 61.4 & 56.8 & 60.2 & 58.0 & 63.1 & 56.2 & 57.0 & 57.0 & 57.6 & 57.4 & 55.7 \\
\hline Noninterest expenses to gross income & 16.9 & 67.0 & 72.2 & 71.2 & 65.9 & 54.1 & 58.3 & 61.1 & 59.1 & 59.1 & 59.0 & 58.4 \\
\hline Personnel expenses to noninterest expenses & 51.7 & 44.7 & 45.7 & 45.2 & 45.4 & 44.4 & 44.4 & 45.3 & 47.3 & 46.6 & 46.4 & 45.9 \\
\hline Trading and fee income to gross income & 33.1 & 39.7 & 45.5 & 41.9 & 43.8 & 32.2 & 43.4 & 43.0 & 43.0 & 40.8 & 41.5 & 43.5 \\
\hline Spread between reference loan and deposit rates (90 days, local curren & 14.0 & 19.0 & 17.4 & 14.7 & 11.5 & 14.6 & 11.2 & 10.7 & 10.6 & 11.0 & 11.0 & 11.1 \\
\hline \multicolumn{13}{|l|}{ Funding and liquidity } \\
\hline Liquid assets to total assets $4 /$ & 34.6 & 53.9 & 57.7 & 58.1 & 55.5 & 51.9 & 53.3 & 49.3 & 34.8 & 32.2 & 30.3 & 28.2 \\
\hline Customer deposits to total (non-interbank) loans & 217.0 & 240.0 & 228.0 & 283.1 & 191.9 & 179.3 & 198.2 & 170.6 & 158.6 & 155.4 & 147.9 & 138.2 \\
\hline Foreign exchange liabilities to total liabilities & 63.3 & 61.3 & 46.4 & 41.4 & 45.3 & 42.8 & 35.5 & 32.2 & 28.5 & 27.6 & 34.9 & 33.6 \\
\hline
\end{tabular}

1/ Includes credit cards and consumer credit lines for vehicle and durable goods.

2/ Includes credit to all other sectors not discriminated above or yet to be identified.

$3 /$ Nonperforming loans are defined according to Mozambican accounting standards (they include only part of the past-due loans).

4/ Includes deposits at parent banks. 
Table 8. Mozambique: Quantitative Assessment and Performance Criteria and Indicative Targets 1/ (Millions of meticais, unless otherwise specified)

\begin{tabular}{|c|c|c|c|c|c|c|c|}
\hline \multirow{3}{*}{\multicolumn{2}{|c|}{ 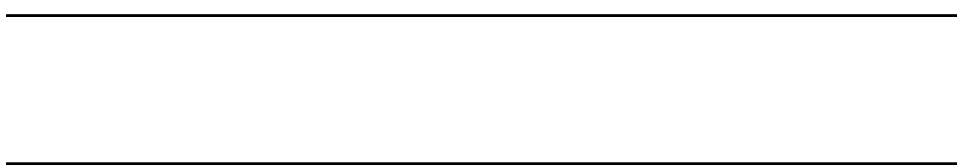 }} & \multicolumn{2}{|l|}{2009} & \multicolumn{4}{|c|}{2010} \\
\hline & & $\begin{array}{c}\text { End-Sept } \\
\text { Indicative Target }\end{array}$ & $\begin{array}{c}\text { End-Dec } \\
\text { Performance/Assessment } \\
\text { Criteria }\end{array}$ & $\begin{array}{l}\text { End-March } \\
\text { Indicative } \\
\text { Target }\end{array}$ & $\begin{array}{l}\text { End-June } \\
\text { Assessment } \\
\text { Criteria }\end{array}$ & $\begin{array}{l}\text { End-Sept } \\
\text { Indicative } \\
\text { Target }\end{array}$ & $\begin{array}{l}\text { End-Dec } \\
\text { Assessment } \\
\text { Criteria }\end{array}$ \\
\hline & & Prog. Adj. Prog. & Adj. Proq. Prel. Est. & & Prog. & Prog. & Prog. \\
\hline
\end{tabular}

\section{Assessment/Performance Criteria for end-June/December}

Net credit to the government (cumulative ceiling)

Stock of reserve money (ceiling) 2/

Stock of net international reserves of the BM (floor, US\$ millions)

New nonconcessional external debt contracted or guaranteed by the central government or the BM or selected state-owned enterprises with maturity of

one year or more (ceiling, US\$ millions)

Stock of short-term external public debt outstanding (ceiling)

External payments arrears (ceiling)

\section{Indicative targets:}

Government revenue (cumulative floor)

$\begin{array}{rrrrrrrrrr}2,148 & 2,435 & 978 & 2,148 & 2,494 & 790 & -124 & -1,743 & 868 & 933 \\ 19,762 & 20,512 & 21,102 & 22,685 & 23,685 & 24,464 & 21,031 & 24,567 & 25,753 & 28,173 \\ 1,487 & 1,484 & 1,851 & 1,758 & 1,725 & 1,834 & 1,711 & 1,759 & 1,885 & 1,930 \\ & & & & & & & & & \\ 5 & 5 & 5 & 5 & 5 & 5 & 5 & 200 & 200 & 200 \\ 0 & 0 & 0 & 0 & 0 & 0 & 0 & 0 & 0 & 0 \\ 0 & 0 & 0 & 0 & 0 & 0 & 0 & 0 & 0 & 0 \\ 30,624 & 30,624 & 32,859 & 42,553 & 42,553 & 46,733 & 10,810 & 27,049 & 41,732 & 56,474 \\ \ldots & \ldots & \ldots & \ldots & \ldots & \ldots & \ldots & \ldots & 43,562 & 58,424\end{array}$

Priority spending (cumulative floor)

$\begin{array}{llllll} & \ldots & \ldots & \ldots & \ldots & \ldots\end{array}$

43,562

58,424

Sources: Mozambican authorities and IMF staff estimates

For definition and adjustors see the attached Program Monitoring Section of the Memorandum of Economic and Financial Polices and the Technical Memorandum of Understanding.

${ }^{2}$ From June 2010, this is calculated as average of daily values during the third month of the quarter. 
Table 9 . Mozambique: Structural Conditionality under the current PSI/ESF, 2010

\begin{tabular}{|c|c|c|}
\hline Actions & Status & $\begin{array}{l}\text { Expected Date of } \\
\text { Implementation }\end{array}$ \\
\hline 1. Approval by the Minister of Finance of the e-Tributação (e-tax) Strategic Planning Document & Met & May 15,2010 \\
\hline $\begin{array}{l}\text { 2. Strengthening the Revenue Authority (Administração Tributária , AT): enhancing the management IT } \\
\text { system and approving the new organic structure. } \\
\text { (i) enhancement of the management information system; } \\
\text { (ii) submission to the Council of Ministers of two decrees to approve the new organic structure and } \\
\text { remuneration status AT's staff; and } \\
\text { (iii) approval of a resolution by the Interministerial Committee of Civil Service of a resolution that } \\
\text { approves the AT's new career structure. }\end{array}$ & $\begin{array}{l}\text { On track; measure (i) and } \\
\text { (ii) are completed, and } \\
\text { measure (iii) is expected } \\
\text { by the target date. }\end{array}$ & May 31, 2010 \\
\hline 3. Creation of an EITI Secretariat & Met & March 31, 2010 \\
\hline 4. Adoption of a financial sector contingency plan & In progress & May 31, 2010 \\
\hline
\end{tabular}




\section{APPENDIX I}

\section{REPUBLIC OF MOZAMBIQUE: LETTER OF INTENT}

May 24, 2010

Mr. Dominique Strauss-Kahn

Managing Director

International Monetary Fund

Washington, D.C. 20431

U.S.A.

Dear Mr. Strauss-Kahn:

The Government of Mozambique requests the completion of the sixth review under the Policy Support Instrument (PSI) and the second review under the Exogenous Shocks Facility (ESF). It also requests the approval of a successor PSI for 2010-13. In support of this request, we are transmitting the attached Memorandum of Economic and Financial Policies (MEFP), which reviews implementation of our economic program under the current PSI and sets out the government's objectives and policies over the short and medium term under the new program.

These policies are consistent with the government's medium-term Plano de Acẫ para a Reduạo da Pobreza Absoluta II (PARPA II) for 2006-09, which was extended to 2010. It aims to maintain macroeconomic stability, promote diversified and strong economic growth, and reduce poverty. A successor Poverty Reduction Strategy is expected to be approved in the second half of 2010, before the first review of the new PSI.

With respect to the current program, all quantitative assessment/performance criteria (A/PC) through end-December 2009 were met, except for the one on reserve money, for which we request a waiver. Reserve money exceeded the program ceiling because of the continued difficulty in predicting the demand for currency in circulation as a result of both the year-end seasonal surge and the structural shift from the expansion of banking services in the economy. We also made strong progress in implementing our structural reform program.

The government believes that the policies outlined in the MEFP are adequate to achieve the objectives of the successor PSI-supported program. Given our dedication to macroeconomic stability, we stand ready to take any additional measures necessary to achieve our policy objectives. The government will consult with the IMF — at its own initiative or whenever the Managing Director requests such a consultation - should revisions be contemplated regarding the policies contained in the attached MEFP. The government will provide the IMF with such information as the IMF may request to be able to assess the progress made in 
implementing the economic and financial policies and achieving the objectives of the program.

Sincerely yours,

/s/

Manuel Chang

Minister of Finance /s/

Ernesto Gouveia Gove

Governor

Bank of Mozambique

Attachments: $\quad$ Memorandum of Economic and Financial Policies

Technical Memorandum of Understanding 


\section{ATtachment I}

\section{Republic of MozambiQue: Memorandum of Economic and Financial Policies}

May 24, 2010

\section{Performance Under the PSI ANd ESF ARRANGement}

1. Mozambique showed considerable resilience to the global economic crisis. Real GDP expanded by $6 \frac{1}{3}$ percent in 2009 , much stronger than expected. Economic activity benefited from dynamic construction, energy, and financial sectors. However, the global crisis triggered large declines in export receipts and private external borrowing. The impact on external reserves was mitigated by the SDR allocation and ESF resources, resulting in an import reserve coverage above 5 months. The government eased macroeconomic policies to contain spillover effects of the crisis to the domestic economy. An accommodating monetary policy facilitated the substitution of foreign borrowing with an exceptionally strong private sector credit expansion. A strong revenue performance kept the size of the automatic stabilizers small and resulted in a lower-than-expected domestic primary fiscal deficit.

2. All the quantitative performance/assessment criteria (P/AC) were met through endDecember 2009, except for the one on reserve money, for which we request a waiver. Base money exceeded the program ceiling because of the continued difficulty in predicting the demand for currency in circulation as a result of both the year-end seasonal surge and the structural shift arising from the expansion of banking services in the economy. Structural reforms are on track as well. Specifically, the Extractive Industry Transparency Initiative (EITI) secretariat was created at end-March 2010 and both benchmarks related to the Revenue Authority - the strengthening of its organizational structure and adoption of the $e$ tax Strategic Planning Document - are being implemented as planned. However, the financial sector contingency plan envisaged for end-May is likely going to be completed by end-September 2010, partly due to delays in the government's application for, and the World Bank's approval of, funding for the exercise.

\section{ObJectives ANd Policies Going Forward}

\section{A. Economic Objectives}

3. The government takes pride in Mozambique's strong economic performance and successful policy implementation under successive IMF-supported programs. This enabled the country to preserve its sound economic fundamentals, with strong economic growth, single-digit inflation, a relatively comfortable international reserves position, and low external and public debt indicators. As a result, the government has gained some flexibility to ease macroeconomic policies to respond to exogenous shocks - such as the recent global crisis - and, going forward, to step up its economic development efforts. 
4. Such efforts to sustainably raise and broaden the country's productive base are necessary, since Mozambique's economic growth, although high by regional standards, has been trending down over the last decade.

5. Going forward, the government's focus will be on policies to create an environment conducive to strong private sector activity, which is expected to also help ensure that more and more segments of the population will benefit from economic development. Specifically, the government considers the following avenues to be the most promising to help boost economic development: (i) maintaining macroeconomic stability; (ii) encouraging additional national and foreign direct investment in the natural resources export sector; (iii) significantly stepping up public investment in transport and electricity infrastructure, partly financed through nonconcessional external borrowing and/or Public-Private Partnerships (PPP); (iv) improving the business climate; and (v) reaping benefits from regional integration. In all these efforts, the government will closely cooperate with the domestic private sector and tap expertise from development partners.

6. Consistent with these objectives and policies, the government will update Mozambique's Five-Year Government Program (PQG) for 2010-14 and adopt it by mid2010. The development plan will be supplemented by an updated Poverty Reduction Strategy, which will be drafted involving the private sector, civil society, and development partners, and finalized in the second half of 2010, before the first review under the PSI.

\section{B. Macroeconomic Outlook}

7. As the global economic crisis wanes, the economic outlook is expected to become more favorable. Real GDP growth should accelerate to $6 \frac{1}{2}$ percent in 2010 and 73 aercent by 2013 , largely because of new megaprojects, stepped-up public investment in areas with an expected large growth dividend, and larger private sector participation. Continued prudent macroeconomic policies should keep inflation at around 6 percent on average over the medium term, with a temporary spike in 2010 to above 9 percent following the gradual removal of the fuel subsidy. The government's investment plans should not fundamentally burden the current account and reserve levels; the current account (after grants) and international reserves are expected to hover around 14 percent of GDP and above five months of imports, respectively, over the next three years.

\section{Macroeconomic Policy Mix}

8. In 2010, the government intends to gradually unwind the temporary monetary and fiscal stimulus which helped Mozambique weather the impact of the global economic crisis. In particular, the Bank of Mozambique (BM) will begin to reverse, in tandem with the expected recovery of global credit markets, the sharp easing of monetary policy that facilitated substitution of foreign borrowing with domestic credit in the wake of the crisis in 2009. This should also help ward off potential inflationary pressures arising from the 
recent exchange rate depreciation and from spillovers from the removal of the fuel subsidy, while sustaining credit quality. As to fiscal policy, the strength in revenue collections is expected to continue and should allow a full reversal of the automatic stabilizers and a moderate reduction in the primary domestic deficit relative to 2009.

9. Over the medium term, the government will adjust its macroeconomic policy mix to gradually and prudently increase public investment to close gaps in transport and electricity infrastructure and thus help raise the country's growth potential. To this end, the fiscal stance will be adjusted to make room for higher domestic and external borrowing, over a limited time horizon, to implement selected high-priority projects with an expected high economic return. Part of the external borrowing is expected to be on nonconcessional terms. Although this will worsen Mozambique's low debt indicators, the limited time horizon of the planned investment increase and our commitment to concentrate on investment projects with a high growth dividend should ensure that debt sustainability is not at risk.

10. The temporary time horizon of the surge in capital spending will be consistent with macroeconomic stability and debt sustainability. It is not expected to crowd out private investment nor create pressure on domestic demand, as labor markets are underutilized and the investments will have a high import component. In addition, the domestic primary fiscal deficit will remain moderate, and monetary policy will be appropriately tight to ward off inflationary pressures while supporting a continued financial deepening. Should domestic demand pressures materialize, the authorities stand ready to adjust macroeconomic policies accordingly.

\section{0 budget implementation}

\section{Fiscal Policy}

11. The government aims to reduce the domestic primary deficit by $1 / 4$ percentage point, to 4.2 percent of GDP, in 2010. This mainly reflects our intention to further improve tax administration and contain current expenditure. While the 2010 budget law anticipates strong efficiency gains in tax administration that could boost the revenue-to-GDP ratio by 0.7 percentage point, to $18 \% / 4$ percent of GDP, the government will base its budget execution on more conservative assumptions. As a result, the government will take the following measures to keep domestic current spending broadly unchanged in terms of GDP relative to 2009 until evidence of a stronger revenue performance materializes:

- In accordance with legal provision of the 2010 Budget Law (Article vii), the Council of Ministers approved the decree on the provisions regarding budget execution (Delegação de Competê ncia sobre a Execuão do Orçamento) on Apri 1 27, 2010. In addition, on May 18, 2010, the Minister of Finance issued the interministerial regulation (Circular Ministerial) providing the guidance for line ministries for budget execution and contingencies. This legal framework, which is consistent with the general Public Financial Management Law (SISTAFE 2002), limits budget execution to 
cautionary ceilings as long as revenue collections remain uncertain. According to those provisions, such ceilings are: (i) 90 percent for goods and services and other current expenditures; (ii) 85 percent for civil service wages and transfers; and (iii) 90 percent for domestically financed capital spending. As a result, spending in those categories is currently envisaged to be MT 6.7 billion (2.2 percent of GDP) below appropriations in the 2010 budget law. The decision to spend beyond those ceilings will be taken by midNovember.

12. The government has initiated the phasing out of the fuel subsidy and aims to gradually restore market-based retail prices by the third quarter of 2010 . The date of the full pass-through will depend on international price movements but will ultimately entail the unconstrained application of the existing monthly price adjustment formula. To ensure transparency, the government will explicitly show fuel subsidies in its budget documents. With a view to protecting vulnerable segments of the population, the government considers replacing the fuel subsidies with better targeted and more effective alternative measures benefiting those truly in need, in consultation with development partners.

\section{Medium-term fiscal stance}

13. The government aims to step up its investment in transport and electricity infrastructure while safeguarding macroeconomic stability. To this end, the medium-term fiscal stance envisages enhanced borrowing from domestic and external sources over a limited time horizon of five years, which would lead to a concomitant temporary rise in the overall fiscal deficit (after grants). During the same period, the government commits to preserve the domestic primary deficit at around 4 percent of GDP. This entails that the expected efficiency gains in revenue administration of 2 percent of GDP will be channeled toward enhancing domestic spending priorities, without any additional recourse to financing.

\section{Stepping up investment}

14. The focus of the central government's investment strategy will be in transport and electricity infrastructure. This is to ensure that the expected growth effect materializes and the scaling up is consistent with the macroeconomic framework. Priority will be given to projects that could have a catalytic effect on private investment. Any new contracting of nonconcessional external borrowing or guarantees by the Central Government and selected state-owned entities (SOEs) subject to the related continuous quantitative AC (see below) will be in those sectors (continuous structural benchmark). The government is currently assessing the prioritization and sequencing of infrastructure investment projects and expects to complete this process by the time of the first program review. It expects that several of the key projects will enjoy financing and/or co-financing from development partners, while others could be developed under a concession or a Public-Private Partnership (PPP). For any projects chosen to be financed with nonconcessional resources, the government will share all project feasibility studies — including those from donors co-financing possible projects - with 
Bank and Fund staff. Among the projects under evaluation by the government, the following specific projects enjoy the highest priority at present:

- $\quad$ The international airport of Nacala in Nampula province, which would play a pivotal role in developing the northern part of the country and in servicing a special economic zone;

- The rehabilitation of the port of Beira, which is strategically located between the northern and southern parts of the country and also serves Malawi and Zimbabwe, the landlocked neighboring countries;

- An expansion of electricity production at the Cahora-Bassa dam in central Mozambique, which should enhance the reliability of the supply of electricity;

- The construction of a power line between the Cahora-Bassa dam and Maputo, which would reduce the dependency on electricity re-imports; and

- An expansion and/or rehabilitation of the road network, as currently only about onethird of Mozambique's road infrastructure is asphalted. Possible priority projects could include the completion of the transit corridor connecting the port of Beira with Zimbabwe, with the rehabilitation of the remaining section from Beira to Inchope $(120 \mathrm{~km})$; and the road between the provinces of Gaza and Maputo $(170 \mathrm{~km})$, which would connect areas with high potential for tourism and agriculture.

\section{Borrowing strategy}

15. The government aims to implement its stepped-up investment plans by tapping domestic and international financing. As a general principle, the government will aim to rely on the creation of fiscal space through a strengthening of revenue collections, grants, and concessional borrowing first before increasing domestic and external financing:

- $\quad$ Domestic Financing. The government will limit its annual recourse to domestic financing to less than 1 percent of GDP over the medium term. This is expected to avoid crowding out the private sector. For 2010, the ceiling on net credit to the government is set at MT -1743 million for end-June (indicating a net accumulation in deposits) and MT 933 million for end-December (quantitative AC); these levels largely reflect a drawdown of deposits related to the advance disbursement of World Bank budget support in late 2009. The government and the BM will enhance their coordination on cash flow management, so as to facilitate the BM's liquidity forecasting and monetary operations.

- External financing. Concessional donor funds will remain the prime sources of financing in the foreseeable future. Nonetheless, given the size of the planned investment push, the government intends to contract nonconcessional external borrowing of no more than US\$900 million during the three-year program period, 
averaging about $2^{1 / 2}$ percent of GDP per year. An annual borrowing profile for the program period will be defined by the time of the first program review when the planning of size, purpose and timing of our investment plans will have been firmed up. At this stage, the contracting or guaranteeing of nonconcessional external loans by the central government and key state-owned entities, including the Road Fund, for the investment projects in the infrastructure and energy sectors defined in the previous section will be limited to US\$200 million for 2010 (continuous quantitative AC).

16. By end-November 2010, the government will finalize a comprehensive multi-year debt strategy. The preparation of the debt strategy will be supported by FSTAP technical support and closely coordinated with Bank and Fund staff, including during the drafting stage. Key elements of the strategy are expected to include steps to derive an annual borrowing profile and calendar, lengthen the maturity structure to help extend the domestic yield curve, develop the institutional framework of domestic financial markets, and identify possible external financing options (structural benchmark).

17. In the same vein, the government will continue to strengthen its debt management. The debt unit in the Ministry of Finance will benefit from the addition of qualified staff to facilitate the semi-annual production of a debt sustainability analysis (DSA); the first such analysis will be completed and published by end-September 2010 (structural benchmark). The addition of necessary technical expertise aims to help the government make informed decisions about borrowing options (such as choice of instruments, size, currency, and maturity) and the evaluation of possible risks (such as rollover, currency and interest rate risk). The debt unit will also benefit from technical advice from the IMF and World Bank and the creation of a debt management committee (DMC), which will provide technical and analytical support for the development of the macroeconomic framework and DSA; the DMC will comprise staff of the Ministries of Finance, Planning and Development, the BM, and other relevant institutions, as needed.

\section{Priority social spending}

18. The government recognizes the importance to protect priority social spending to help sustain progress toward meeting the MDGs, including especially with respect to reducing poverty. Such spending is defined consistently with the PARPA classification. Such spending averaged 17.3 percent of GDP during 2007-09, representing 62 percent of total expenditure. It will be raised to 19.1 percent of GDP in 2010, equivalent to about 62.3 percent of total spending. An indicative floor of such spending is incorporated in the program. The definition of priority spending will be aligned with the any revisions to the concept under the new FiveYear Government Program ( $P Q G)$ and the successor poverty reduction strategy once they are finalized. 


\section{E. Fiscal Structural Reforms}

\section{Expanding budget coverage}

19. While at present the fiscal stance is measured on a central government basis, the government will expeditiously work toward integrating the Road Fund, the water authority (FIPAG), and the electricity company (EDM) into the fiscal and debt analysis. To this end, by end-June 2010, the government, with technical advice by Fund staff, will develop a fiscal template that will consolidate the revenue, expenditure, and financing of the central government and those entities, in consultation with Fund staff. On this basis, the government will produce by end-August 2010 quarterly consolidated fiscal accounts beginning in 2008 . The Law on Public Enterprises, as mentioned above, will further stipulate the reporting requirements of SOEs to the government. This will form a basis for further broadening budget coverage over time, which we will undertake supported by Fund technical advice.

\section{Revenue effort}

20. The government will strive to raise its revenue-to-GDP ratio by 1.5 percentage points during the program period. A quantitative indicative target will help monitor progress in this regard. Technical assistance has helped focus the reforms in the areas of tax administration and tax policy on the following key initiatives:

- $\quad$ Rolling out the electronic tax system e-Tributação (e-tax): Following the approval of the e-Tributaço Strategic Planning document on May 15, 2010, the government will approve in 2010 a procedure manual on the collection of the corporate income tax as a pilot for the e-tax roll-out. The revenue authority has also defined a set of concrete actions aimed at strengthening tax collection and improving the business environment. This includes the introduction of online tax filing and the possibility to pay taxes via bank transfer.

- $\quad$ Reinforcing large taxpayers unit (LTU): The national coordination unit for large tax payers, responsible for planning and monitoring all large taxpayers in the country including megaprojects, will initiate its operations by end-June 2010.

- Tax policy: To create a level playing field and improve the business environment, the government will assess the recommendations of the recent Fund technical assistance mission by the time of the first program review. As a first step, the government will create the legal basis for the tax treatment of new financial instruments, including mutual funds, leasing, and securitized loans.

\section{Wage policy}

21. The government will continue implementing a reform of the civil service pay scale. It approved a new salary policy in September 2008 that it will phase in over the medium term in a very gradual manner, in line with the need to preserve macroeconomic stability and fiscal sustainability. This gradual approach will stabilize the wage bill below $9 \frac{1}{4}$ percent of 
GDP over the medium term. The new policy aims to simplify and rationalize the salary scales across ministries, decompress the scales consistent with qualification and responsibility, reform the system of housing and other allowances, and harmonize the salary policy with the pension system. Further technical work, supported by development partners, will be undertaken in 2010 to help determine specific elements and the sequencing of reform steps.

\section{Strengthening public financial management (PFM)}

22. Based on the PFM vision paper and the 2010-12 SISTAFE Action Plan and Budget, the government envisages the following key measures in the short run:

- $\quad$ Continued implementation of SISTAFE system: e-SISTAFE will be further rolled out to 15 districts and 35 institutions. Budget execution through e-SISTAFE will gradually increase to 37.5 percent of the executed budget by end-2010. Its program classifiers will be further developed consistent with sectoral accounting, planning and reporting needs.

- $\quad$ Rolling out e-FOLHA: In order to increase coverage of the e-SISTAFE, by endSeptember 2010 the salary calculation and processing functionality will be rolled out to 8 sectors at the central level and to the City and Province of Maputo for a gradual introduction of direct salary payments into bank accounts.

- Improved integration of internal audit in e-SISTAFE system: The General Inspectorate of Finance (IGF) will move toward risk-based audits in light of the gradual roll-out of e-SISTAFE. To this end, IGF will issue a circular to financial departments of line ministries by September 2010 specifying that internal audit will be based on electronic e-SISTAFE reports wherever the system is used. In addition, to reflect emerging fiscal risks from the stepping up of infrastructure investments, IGF will reinforce its work program on state owned enterprises and PPPs.

- Improving aid management: The MF will actively encourage donors to use the singleand multi-currency treasury accounts at the BM for disbursing project aid.

- $\quad$ Reinforcing investment planning, limiting fiscal and quasi-fiscal risks, and maximizing economic benefits: By end-September 2010, the Council of Ministers will adopt a PPP Law, which will also be applicable to mega projects and other concessions, including those in the power generation area (structural benchmark). The law will include the creation of the PPP unit within the Ministry of Finance and the mechanisms to formalize the PPP approval process. It will also introduce 'gateway' decision points where the consensus of the Ministry of Finance would be required before the PPP can proceed, so as to manage risks. Implementation of the new framework will be facilitated by the creation of the new PPP unit in the Ministry of Finance to support the gateway process and improve financial oversight of PPPs, including through mandated regular reporting from PPPs on their financial statements to the PPP unit. The unit should be operational by end- 2010 . 
- Improving the framework for public enterprises: A Public Enterprises Law will be adopted by the Council of Ministers by end-July 2010. Among other things, it will ringfence commercial activities of state-owned entities and require quarterly financial reporting to the Ministry of Finance and an annual tabulation of financial and other assets to the General State Accounts. It will also reaffirm the existing provisions that have limited contingent liabilities emanating from state-owned entities, including the need to obtain approval by the Minister of Finance for all borrowing.

- $\quad$ Enhancing procurement systems: Following up on the Country Procurement Assessment Report (CPAR), the government will adopt terms of reference for carrying out procurement audits in order to assess the integrity and transparency of the system. The ministries that are to be audited in 2011 will be selected by December 2010. By end-June 2010, a strategy for training and capacity development will be defined, and by end-December 2010, the terms of reference for the development of a career in government procurement and certification of experts in this area will be formulated.

\section{Reforming the National Institute for Social Security (INSS)}

23. To limit fiscal risks and improve governance and transparency, the government is reassessing its approach to reform the INSS. The adoption of a new investment strategy has been delayed, pending further necessary conceptual work supported by World Bank technical assistance. The new investment strategy will aim solely at protecting the interest of the beneficiaries of the social security system and be approved by end-June 2010. The INSS will also: (i) publish its audited financial statements of 2008 by end-August 2010 and of 2009 by end-2010; (ii) assess its financial viability based on an updated actuarial study that takes into account the financial statements through 2007, and by-end 2010 initiate corrective actions to guarantee the financial equilibrium of the INSS, to be implemented by INSS or to be submitted to the Council of Ministers; (iii) adopt its new organizational structure by endOctober 2010; and (iv) introduce an IT system during 2010 to help improve registration of contributors and claimants and strengthen collection of contributions.

\section{Enhancing governance in the natural resources sector}

24. The government is committed to becoming a full member of EITI within the envisaged timeframe of two years, i.e., by May 2011. This will enhance the contribution of the natural resource sector to economic development as a result of the improved transparency and accountability in the sector. The newly created EITI secretariat will launch a dedicated EITI website by end July 2010, produce and distribute relevant brochures on EITI by endJuly 2010, elaborate the terms of reference for the EITI auditor by end September 2010, and appoint the qualified EITI auditor by end November 2010. 


\section{F. Monetary and Exchange Rate Policies}

25. The BM is committed to prudent monetary and exchange rate policies aimed at containing inflation at around 6 percent on average over the medium term. The monetary expansion consistent with this objective is expected to leave room for private sector credit expansion.

26. In its monetary policy implementation, the BM will continue to pay close attention to the real effective exchange rate vis-àvis a br oad basket of currencies. This should allow the exchange rate to adjust freely to evolving patterns of trade and financial flows while safeguarding Mozambique's international reserves. The BM will continue to be cautious in managing the country's reserves in light of increasing external obligations.

27. The BM will decide whether to move to an inflation targeting framework over the next two years. Supported by IMF technical assistance, the BM is working on establishing the prerequisites for a successful transition, as outlined in the relevant action plan.

Specifically, the BM will: (i) assess which inflation rate should be targeted and what core inflation rate should be used to assess inflationary conditions; (ii) enhance its monitoring, understanding, and capacity to project the monetary transmission mechanism; (iii) adopt and implement new monetary instruments to steer monetary conditions effectively; and (iv) improve its communications strategy with the public.

28. During the interim period, the BM will continue its reserve money targeting. A particular challenge will continue to be the structural shifts and seasonal surges in the demand for currency. To this end, the BM will:

- $\quad$ Improve reserve money targeting. Such targeting will be based on monthly averages, which will neutralize the spike in cash during the last two weeks of each month; and

- $\quad$ Further enhance liquidity and foreign exchange management. The BM will enhance coordination with the Ministry of Finance on domestic and external borrowing plans, aid management, and cash flow projections, as well as with banks on their liquidity requirements, as the potentially significant increase in foreign exchange inflows from the government's borrowing plans is likely to accentuate the BM's liquidity and foreign exchange management challenges.

29. The government intends to accept the obligations under Article VIII sections 2, 3, and 4 of the Fund's Articles of Agreement in due course. The official communication will be sent as soon as the implementation regulation has been brought in line with the new legislative framework that came into effect on March 11, 2009. 


\section{G. Financial Sector Policies}

30. The government and the BM will ensure expeditious follow-up to the recommendations of the 2009 Financial Sector Assessment Program (FSAP) update and recent technical assistance:

- Developing Financial Sector Action Plan. After some delay, the interagency task force will promptly finalize an action plan to implement the FSAP recommendations by endJuly 2010. The plan will include measures to enhance access to finance and financial market development, strengthen compliance of the supervisory framework with Basel Core Principles, and complete the modernization of the payments system.

- $\quad$ Stepping up risk management: In line with FSAP recommendations, the BM will issue regulation (Aviso) on risk management by end-December 2010. The government is working on a draft decree on deposit insurance which it intends to issue by year-end.

- Enhancing supervision of banking system. Following the rapid credit growth over the last two years, the BM will closely supervise activities in the banking system and encourage banks to develop a stress testing framework. Close attention will be devoted to assessing liquidity conditions and the quality of loan portfolios.

- $\quad$ Fighting money laundering and financial crime: Following the Inter-Ministerial Civil Service Committee's approval in April 2010 to hire new staff, the Gabinete de

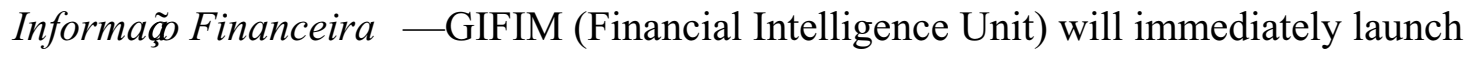
the recruitment process and proceed with the necessary capacity building, supported by development partners. The draft amendment to the 2002 AML law, which will remove incompatibilities between the law establishing the GIFIM and the AML law, will be submitted to Parliament by end-August 2010.

\section{H. Other Structural Policies}

31. The government is intensifying its reforms to improve the business environment to help raise Mozambique's growth potential, diversify exports, and stimulate new investment. In coordination with the World Bank, it will work toward implementing a range of fast-track measures by end-2010. This is expected to ease red tape, streamline the granting of businessrelated licenses, improve bankruptcy proceedings, and facilitate trading across borders.

32. The Government aims to improve its statistical data compilation and dissemination. This should facilitate migration to the Special Data Dissemination System (SDDS) in due course. The Government will focus on improving data quality related to the quarterly national accounts, consumer prices index, government finance statistics, and megaprojects, consistent with IMF technical assistance advice. In particular, the INE will choose a new calculating software before the new rebased Maputo CPI is launched in 2011; this will 
remove the possible bias of the CPI. INE also intends to increase the geographic coverage of the CPI by including the Greater Maputo area and the populous province of Zambezia.

\section{Program Monitoring}

33. The quantitative AC for end-June 2010 and end-December 2010 and indicative targets for the second half of 2010 are shown in Table 1. Table 2 lists the structural benchmarks for the new PSI. The first PSI review is expected to be completed by endDecember 2010 and the second PSI review by end-June 2011. 
Table 1. Mozambique: Quantitative Assessment and Performance Criteria and Indicative Targets $1 /$ (Millions of meticais, unless otherwise specified)

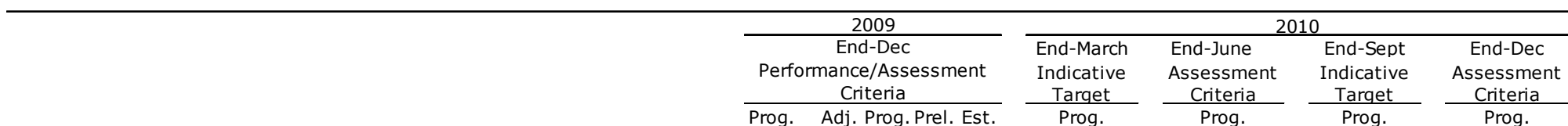

\section{Assessment/Performance Criteria for end-June/December}

Net credit to the government (cumulative ceiling) 2/

Stock of reserve money (ceiling)

Stock of net international reserves of the BM (floor, US\$ millions)

New nonconcessional external debt contracted or guaranteed by the central

government or the BM or selected state-owned enterprises with maturity of

one year or more (ceiling, US\$ millions)

Stock of short-term external public debt outstanding (ceiling)

External payments arrears (ceiling)

Indicative targets:

Priority spending (cumulative floor)

\begin{tabular}{rrrrrrr}
2,148 & 2,494 & 790 & -124 & $-1,743$ & 868 & 933 \\
22,685 & 23,685 & 24,464 & 21,031 & 24,567 & 25,753 & 28,173 \\
1,758 & 1,725 & 1,834 & 1,711 & 1,759 & 1,885 & 1,930 \\
& & & & & & \\
5 & 5 & 5 & 5 & 200 & 200 & 200 \\
0 & 0 & 0 & 0 & 0 & 0 & 0 \\
0 & 0 & 0 & 0 & 0 & 0 & 0 \\
42,553 & 42,553 & 46,733 & 10,810 & 27,049 & 41,732 & 56,474 \\
$\ldots$ & $\ldots$ & $\ldots$ & $\ldots$ & $\ldots$ & 43,562 & 58,424 \\
\hline
\end{tabular}

933

Sources: Mozambican authorities and IMF staff estimates

' For definition and adjustors see the attached Program Monitoring Section of the Memorandum of Economic and Financial Polices and the Technical Memorandum of Understanding.

${ }^{2}$ From June 2010, this is average of the daily stock of reserve money and FDP in the third month of the quarter. 


\section{Table 2. Mozambique: Structural Benchmarks for Successor PSI}

Mozambique: Structural Benchmarks for Successor PSI

\begin{tabular}{|c|c|}
\hline Actions & $\begin{array}{l}\text { Expected Date of } \\
\text { Implementation }\end{array}$ \\
\hline $\begin{array}{l}\text { Any new contracting of nonconcessional external borrowing } \\
\text { or guarantees by the Central Government and selected state- } \\
\text { owned entities (SOEs) subject to the related continuous } \\
\text { quantitative AC will be for transportation and electricity } \\
\text { infrastructure investment, as described in paragraph } 14 \text { of } \\
\text { the MEFP. }\end{array}$ & Continuous \\
\hline $\begin{array}{l}\text { Adoption by Council of Ministers of PPP, Concessions and } \\
\text { Megaprojects Law, as described in paragraph } 22 \text { of the } \\
\text { MEFP. }\end{array}$ & End-September 2010 \\
\hline $\begin{array}{l}\text { Finalization of a comprehensive debt strategy that will } \\
\text { assess the risk profile and the fiscal and macroeconomic } \\
\text { implications of new borrowing, as described in paragraph } 16 \\
\text { of the MEFP. }\end{array}$ & End-November 2010 \\
\hline $\begin{array}{l}\text { Completion of first Government Debt Sustainability Analysis, } \\
\text { as described in paragraph } 17 \text { of the MEFP. }\end{array}$ & End-September 2010 \\
\hline
\end{tabular}




\section{ATTACHMENT II}

\section{Republic of MozambiQue: Technical Memorandum of Understanding}

May 24, 2010

1. This Technical Memorandum of Understanding (TMU) defines the quantitative assessment criteria, indicative targets, and structural benchmarks on the basis of which the implementation of the Fund-supported program under the Policy Support Instrument (PSI) will be monitored. In addition, the TMU establishes the terms and timeframe for transmitting the data that will enable Fund staff to monitor program implementation.

\section{DEFINITIONS}

\section{Net credit to the central government}

2. Net credit to the central government (NCG) by the banking system is defined as the difference between the outstanding amount of bank credits to the central government and the central government's deposits with the banking system, excluding deposits in project accounts with the banking system, recapitalization bonds issued to the BM, and proceeds from the signing fee for mineral resource exploration. Credits comprise bank loans, advances to the central government and holdings of central government securities and promissory notes. NCG will be calculated based on data from balance sheets of the monetary authority and commercial banks as per the monetary survey. The limits on the change in NCG by the banking system will be cumulative from end-December of the previous year.

3. The central government encompasses all institutions whose revenue and expenditure are included in the state budget (Orçamento do Estado) : central government ministries, agencies, and the administration of 11 provinces. Although local governments (33 municipalities or autarquias) are not included in the definition because they are independent, the bulk of their revenue is registered in the state budget as transfers to local governments.

\section{Government revenue and financing}

4. Revenue is defined to include all receipts of the General Directorate of Tax (Direcậ Geral dos Impostos, DGI), the General Directorate of Customs (Direç̧̃o Geral das Alfândegas, DGA), and nontax revenue, including certain own-generated revenues of districts and some line ministries, as defined in the budget. Net receipts from privatization received by the National Directorate of State Assets (Direcção Nacional do Património do Estado) and unrealized profits transferred by the central bank to the treasury will not be considered as revenue (above the line) and will be accounted for as other domestic financing (below the line). 
5. For the purpose of program monitoring, revenue is considered as collected at the time when it is received by the relevant government collecting agencies, in cash or checks, or through transfers into the respective bank account.

\section{Priority social spending}

6. Priority social spending is based on the PARPA program categories. Accordingly, it will include total spending in the following sectors: (i) education; (ii) health; (iii) HIV/AIDS; (iv) infrastructure development; (v) agriculture; (vi) rural development; and (vii) governance and judicial system.

\section{Reserve money}

7. For the purposes of program monitoring reserve money is defined as the sum of currency issued by the BM and commercial banks' holdings at the BM. The target is defined in terms of the average of the daily end-of-day stocks in the month of the test date. The reserve money stock will be monitored and reported by the BM.

\section{Net international reserves}

8. Net international reserves (NIR) of the BM are defined as reserve assets minus reserve liabilities. The BM's reserve assets include (a) monetary gold; (b) holdings of SDRs; (c) reserve position at the IMF; (d) holdings of foreign exchange; and (e) claims on nonresidents, such as deposits abroad (excluding the central government's savings accounts related to mineral resource extraction concessions). Reserve assets exclude assets pledged or otherwise encumbered, including but not limited to assets used as collateral or guarantee for a third-party external liability (assets not readily available). The BM's reserve liabilities include: (a) all short-term foreign exchange liabilities to nonresidents with original maturity of up to and including one year; and (b) all liabilities to the IMF.

\section{New nonconcessional external debt contracted or guaranteed by the central government, the BM, and selected state-owned enterprises, with maturity of more than one year}

9. The ceiling on nonconcessional external debt applies to external debt contracted or guaranteed by the central government, the BM, the Road Fund, the water authorities (FIPAG), and the electricity company (EDM). It also applies to debt contracted by these three state-owned enterprises from domestic banks or from other state-owned enterprises that is contractually inter-related to external nonconcessional loans.

10. The ceiling applies to external debt with original maturity of one year or more and with a grant element below 35 percent. The grant element is calculated using currencyspecific discount rates based on the Organization for Economic Cooperation and Development (OECD) commercial interest reference rates in accordance with the annual 
Budget Law. The term 'debt' will have the meaning set forth in Point 9 of the Guidelines on Performance Criteria with Respect to External Debt in Fund Arrangements adopted on August 3, 1979, as amended August 31, 2009, effective December 1, 2009. The concept of external debt is defined on the basis of the residency of the creditor. The ceiling also applies to commitments contracted or guaranteed for which value has not been received. This assessment criterion will be assessed on a continuous basis.

\section{Stock of short-term external public debt outstanding}

11. The central government will not contract or guarantee external debt with original maturity of less than one year. This assessment criterion applies not only to debt as defined in Point 9 of the Guidelines on Performance Criteria with Respect to External Debt in Fund Arrangements adopted on August 3, 1979, as amended August 31, 2009, effective December 1, 2009, but also to commitments contracted or guaranteed for which value has not been received. Excluded from this assessment criterion are short-term, import-related trade credits. This assessment criterion will be assessed on a continuous basis.

\section{External payments arrears}

12. The government undertakes not to incur payments arrears on external debt owed or guaranteed by the central government, with the exception of external payments arrears arising from government debt that is being renegotiated with creditors. This assessment criterion will be assessed on a continuous basis.

\section{Foreign program assistance}

13. Foreign program assistance is defined as grants and loans received by the Ministry of Finance through BM accounts excluding those related to projects (Table 1).

\section{Actual external debt service payments}

14. Actual external debt service payments are defined as cash payments on external debt service obligations of the government and central bank, including obligations to Paris Club and other bilateral creditors rescheduled under enhanced HIPC Initiative completion point terms, multilateral creditors, and private creditors, but excluding obligations to the IMF (Table 1).

\section{ADJUSTERS}

\section{Net international reserves}

15. The quantitative targets (floors) for net international reserves (NIR) will be adjusted:

- downward by the shortfall in external program aid less debt service payments (up to US\$100 million), compared to the program baseline (Table 1); 
- downward/upward for any revision made to the end-year figures corresponding to the previous year; and

- downward to accommodate higher external outlays because of natural disasters, up to US\$20 million.

\section{Net credit to central government}

16. The quantitative targets (ceilings) for net credit to the central government (NCG) will be adjusted:

- upward by the shortfall in the MT value of external program aid receipts less debt service payments (up to the MT equivalent of US $\$ 100$ million at exchange rates prevailing at the respective test dates), compared to the program baseline (Table 1);

- downward by privatization proceeds in excess of those envisaged in the program, unless these proceeds are deposited in the government's savings accounts abroad;

- downward (upward) for any increase (decrease) in domestic financing from the nonfinancial private sector; and

- upward to accommodate the higher locally-financed outlays because of natural disasters, up to the MT equivalent of US\$20 million at exchange rates prevailing at the respective test dates.

\section{Reserve money}

17. The quantitative target (ceiling) for reserve money will be adjusted upward by the excess of the stock of currency in circulation above the level envisaged in the program. The target is defined in terms of the average of the daily end-of-day stocks in the month of the test date. The target will be adjusted up to MT 500 million for end-March, end-June, and end-September and up to MT 750 million for end-December (Table 1).

\section{DATA AND OTHER REPORTING}

18. The government will provide Fund staff with:

- monthly and quarterly data needed to monitor program implementation in relation to the program's quantitative targets and broader economic developments;

- $\quad$ weekly updates of the daily data set out in Table 1;

- weekly data set out in Table 4 of the TMU dated May 26, 2005;

- monthly updates of the foreign exchange cash flow of the BM;

- monthly data on government revenues (in detail according to the fiscal table) with a lag not exceeding one month; 
- $\quad$ monthly information on the balance of government savings accounts abroad;

- $\quad$ monthly data on domestic arrears;

- monthly budget execution reports (that will also be published) with a time lag not exceeding 45 days; and

- monthly data on gross international reserves, with the composition by original currencies and converted to US dollars at the actual exchange rates.

19. The monetary survey made available by the BM will clearly identify donor-financed project deposits (with a breakdown between foreign and domestic currency) included in net credit to the government in both the central bank's and commercial banks' balance sheets.

20. The government will provide Fund staff with documentation concerning external loan agreements once these have been signed and become effective. 
TMU Table 1. Mozambique: Net Foreign Assistance, 2009-10

\begin{tabular}{|c|c|c|c|c|c|c|c|c|c|}
\hline & \multicolumn{4}{|c|}{2009} & \multicolumn{5}{|c|}{2010} \\
\hline & \multicolumn{2}{|c|}{ Q4 } & \multicolumn{2}{|c|}{ Year } & Q1 & Q2 & Q3 & Q4 & Year \\
\hline & Prog. & Act. & Prog. & Act. & \multicolumn{5}{|c|}{ Prog. } \\
\hline Net foreign program assistance (US\$ mn) & 127 & 128 & 446 & 421 & 71 & 181 & 27 & 145 & 424 \\
\hline Gross foreign program assistance & 144 & 140 & 501 & 468 & 86 & 203 & 42 & 165 & 496 \\
\hline Program grants & 34 & 30 & 361 & 327 & 86 & 176 & 42 & 55 & 359 \\
\hline Program loans & 110 & 110 & 140 & 140 & 0 & 27 & 0 & 110 & 137 \\
\hline External debt service & 17 & 12 & 56 & 46 & 15 & 22 & 15 & 20 & 71 \\
\hline World Bank PRSC 6 Disbursement & 110 & 110 & 110 & 110 & 0 & 0 & 0 & 0 & 0 \\
\hline Net foreign program assistance (MT mn) & 2,885 & 3,743 & 11,331 & 11,777 & 1,991 & 5,378 & 829 & 4,582 & 12,781 \\
\hline Gross foreign program assistance & 3,895 & 4,062 & 13,270 & 12,923 & 2,406 & 6,021 & 1,278 & 5,218 & 14,923 \\
\hline Program grants & 928 & 1,067 & 9,500 & 9,125 & 2,406 & 5,229 & 1,278 & 1,741 & 10,655 \\
\hline Program loans & 2,967 & 2,996 & 3,770 & 3,798 & 0 & 792 & 0 & 3,476 & 4,268 \\
\hline External debt service & 1,010 & 320 & 1,939 & 1,147 & 415 & 643 & 449 & 636 & 2,142 \\
\hline World Bank PRSC 6 Disbursement & 2,697 & 2,769 & 2,697 & 2,769 & 0 & 0 & 0 & 0 & 0 \\
\hline Stock of outstanding currency (MTm) & 15,004 & 16,117 & 15,004 & 16,117 & 14,057 & 16,445 & 16,436 & 19,222 & 19,222 \\
\hline
\end{tabular}

Source: Mozambican authorities and IMF staff estimates 


\title{
INTERNATIONAL DEVELOPMENT ASSOCIATION AND INTERNATIONAL MONETARY FUND
}

\author{
REPUBLIC OF MOZAMBIQUE \\ Joint World Bank/IMF Debt Sustainability Analysis \\ Prepared by the staffs of the International Development Association and \\ the International Monetary Fund \\ Approved by Sudarshan Gooptu and Sudhir Shetty (World Bank) \\ and Roger Nord and Dominique Desruelle (IMF)
}

May 27, 2010

The joint IMF-World Bank low-income country debt sustainability analysis (LIC DSA) based on end-2009 debt stocks indicates that Mozambique's risk of debt distress remains low. As in the previous DSA, the external debt indicators remain well below their respective thresholds. However, the government's plans to temporarily increase public investment financed by external borrowing on nonconcessional terms, in line with the Fund's revised Debt Limits Policy, will noticeably increase debt vulnerabilities, as stress tests approach, and in some instances temporarily and marginally exceed, the relevant thresholds. This calls for a cautious approach with such borrowing and resolve to improve debt management capacity. As public debt is largely external, the evolution of public debt indicators largely mirrors that of external debt.

\section{BACKGROUND}

\section{External debt}

1. Mozambique's external public and publicly guaranteed (PPG) debt stock at end2009 was US\$3.45 billion in nominal terms or US\$1.59 billion in PV terms (Table 1). Of this, 67 percent was owed to multilateral creditors, 33 percent to bilateral creditors, while outstanding obligations to commercial creditors were negligible. The debt stock includes about US $\$ 0.7$ billion in obligations to non-Paris Club creditors that at end-2009 had not yet granted debt relief comparable to the HIPC Initiative.

2. The previous full DSA was conducted in late 2008 on the basis of end-2007 debt stocks. At that time, the PV of PPG debt was US\$0.84 billion, and the PV of debt at end2009 was projected to be US\$1.4 billion. The increase in the PV of PPG debt at end-2009 from the previous projection largely reflects in equal part the reduction in the discount rate from 5 to 4 percent and changes in the exchange rate. Borrowing in the interim was broadly 
as expected: disbursements were about 30 percent lower than projected for 2008 but were about 20 percent higher in 2009.

3. Private sector debt accounts for about two-fifths of Mozambique's total external debt, mainly because of borrowing to finance megaprojects. Particularly significant was borrowing of about US\$0.8 billion in 2007 related to the Cahora-Bassa hydroelectric power station.

Table 1. Mozambique: External and Domestic Nominal Debt Outstanding at end-2009

\begin{tabular}{|c|c|c|c|}
\hline & $\begin{array}{c}\text { Millions of US } \\
\text { dollars }\end{array}$ & $\begin{array}{c}\text { Percent of total } \\
\text { external debt }\end{array}$ & Percent of GDP \\
\hline Public and Publicly Guaranteed Debt & 3,745 & & 38.1 \\
\hline Domestic Debt ${ }^{1}$ & 294 & & 3.0 \\
\hline External Debt & 3,451 & 100.0 & 35.1 \\
\hline Multilateral Creditors & 2,307 & 66.8 & 23.5 \\
\hline IMF & 171 & 5.0 & 1.7 \\
\hline $\mathrm{IDA}^{2}$ & 1,339 & 38.8 & 13.6 \\
\hline African Development Bank ${ }^{3}$ & 385 & 11.2 & 3.9 \\
\hline Othe Multilaterals ${ }^{3}$ & 411 & 11.9 & 4.2 \\
\hline Bilateral Creditors ${ }^{3}$ & 1,144 & 33.2 & 11.6 \\
\hline Paris-Club ${ }^{4}$ & 74 & 2.1 & 0.8 \\
\hline Non-Paris Club ${ }^{5}$ & 1,070 & 31.0 & 10.9 \\
\hline Commercial Creditors & 0.0 & 0.0 & 0.0 \\
\hline Total Private and Non-Guaranteed External Debt & 2,605 & & 26.5 \\
\hline \multicolumn{4}{|l|}{ Memorandum Items } \\
\hline Total public and private external debt & 6,055 & & 61.6 \\
\hline PV of external Debt & 4,510 & & 45.9 \\
\hline PV of PPG external debt & 1,589 & & 16.2 \\
\hline PV of non-PPG external debt & 2,921 & & 29.7 \\
\hline Nominal GDP in US dollars & 9,831 & & \\
\hline
\end{tabular}

Sources: Mozambican authorities, and World Bank and IMF staff estimates.

${ }^{1}$ Central Government debt only, excluding deposits held at the banking sector.

${ }^{2}$ World Bank data.

${ }^{3}$ Mozambican authorities' data.

${ }^{4}$ Assumes implementation of debt relief.

${ }^{5}$ Only includes debt relief if concluded. Tables 2 and 4 include obligations assuming debt relief concluded by 2010. 


\section{Debt relief}

4. Mozambique in $\mathbf{2 0 0 1}$ benefited from assistance under the HIPC Initiative provided by multilateral and Paris Club bilateral creditors. ${ }^{1}$ Mozambique received further assistance in 2006 under the Multilateral Debt Relief Initiative (MDRI) from the African Development Fund (AfDF), the International Development Association (IDA) of the World Bank, and the IMF, according to which Mozambique's debt stock fell by US\$1.9 billion in nominal terms in $2006 .^{2}$

5. The authorities have continued working to conclude debt relief agreements with Paris Club creditors under the HIPC Initiative. Since issuance of the last full DSA, the Mozambican authorities have contacted Japan on the formalization and signing of the agreement on all pending debt cancellation. They reconfirmed that Japan is still in the process of coordinating domestic legal and financial issues among relevant ministries to that end. Mozambique has also reached an agreement in principle with Russia that remains to be concluded.

6. Mozambique has experienced delays in negotiating debt relief agreements with some of its non-Paris Club bilateral creditors. Negotiations are still ongoing with Angola, Bulgaria, India, Iraq, Libya, and Poland. The DSA projections assume that negotiations with non-Paris Club creditors will be concluded during 2010.

\section{Domestic debt}

7. The central government's domestic debt at end-2009 amounted to 3 percent of GDP. This debt is low by regional standards, reflecting the government's long-standing commitment to generally avoid domestic financing in an effort to provide sufficient room for private sector credit growth. Most of the government's domestic debt originates from bonds issued to strengthen the central bank's balance sheet during 2005-07 and to restructure commercial banks. It excludes the central bank's securities issued for monetary operations.

\section{Borrowing by state-owned enterprises}

8. The stock of external PPG debt incorporates external borrowing of the central government on-lent to state-owned enterprises (SOEs). The Ministry of Finance holds a veto on SOE's external borrowing. The central government's domestic debt at end-2009, however, does not include domestic obligations incurred by the SOEs, though these are relatively small. The financial positions of the key SOEs do not currently pose any

\footnotetext{
${ }^{1}$ See "Mozambique-HIPC Debt Initiative: President's Memorandum and Recommendation and Completion Point Document" (IDA/R99-139), and "Mozambique-Enhanced HIPC Debt Initiative: President's Memorandum and Recommendation and Completion Point Document”(IDA/R2001-0150).

2 The amount of MDRI relief provided by the AfDF was US\$464.5 million; IDA provided US\$1.3 billion; and the IMF provided US\$120.6 million.
} 
substantive threat to the central government's fiscal position and are not expected to pose a threat in the foreseeable future.

9. Since late $\mathbf{2 0 0 8}$, the government has concluded four-party framework agreements with Portugal for credit lines. These credit lines, totaling 700 million (about 10 percent of GDP), are to help finance infrastructure investment spending during 2010-15. ${ }^{3}$ Contractual partners are the governments of Mozambique and Portugal, the Portuguese savings bank (CGD), and a local bank (BCI). The agreement allows for the extension of external loans to BCI and on-lending of these funds to the road fund, a domestic public entity to finance road infrastructure. The terms for 400 million of the credit lines are concessional, but the terms on the remaining 300 million have a low grant element, as well as a relatively short maturity. ${ }^{4}$ The government has refrained from providing external guarantees, but has guaranteed repayments to the domestic bank. These loans are incorporated into the DSA as part of public external debt, although they do not trigger an assessment under IDA's Nonconcessional Borrowing Policy on technical grounds.

\section{UNDERLYING DSA ASSUMPTIONS}

\section{Macroeconomic assumptions}

10. The underlying macroeconomic assumptions (Box 1) are consistent with the medium-term macroeconomic framework under the Fund-supported program. Projected real GDP growth is below the 8 percent average over the past decade. During the period, growth was supported by large aid flows, as well as high private capital inflows, mainly to the natural resource sector, that together averaged about 20 percent of GDP. But growth has been trending down and requires an ambitious agenda of structural reforms and infrastructure investment to be sustained. The government is therefore aiming to temporarily raise public investment from an average of 11 percent of GDP during the past decade to about 15 percent of GDP over the medium term (or to 17 percent of GDP including the Portuguese credit lines). To continue sustaining growth, public investment will probably remain around 13 percent of GDP beyond the medium term. However, while private capital inflows are likely to be sustained, a tapering off of the significant donor assistance seems likely. The government will therefore need to rely more heavily on domestic resources and resort to external financing on commercial terms.

\section{The recently adopted Fund's new Debt Limits Policy makes room for such} nonconcessional financing. In November 2009, Mozambique was classified as a lower vulnerability/lower capacity country. Its CPIA and PEFA ratings, reflecting the significant PFM and other institutional reforms undertaken by the authorities in recent years, put it at the

\footnotetext{
${ }^{3}$ Lines of credit for 100 million, 400 million, and 200 million were signed in late 2008, late 2009 and early 2010, respectively.

${ }^{4}$ According to the OECD DAC's methodology for assessing concessionality.
} 
threshold of a classification as a high capacity country, although its debt management capacity was considered limited and prevented a higher classification. The authorities are receiving technical assistance from the World Bank through the Financial Sector Technical Assistance Project (FSTAP) to strengthen their debt management capacity. Under the new three-year economic program supported by the Fund's Policy Support Instrument, the authorities are committed to preserving macroeconomic stability, pursuing their reform agenda in public financial management, tax policy, and tax administration, and strengthening debt management. ${ }^{5}$ In view of these commitments, some untied limits on nonconcessional borrowing are envisaged during this period, consistent with the Fund's new Debt Limits Policy.

\section{Investment and growth}

\section{The impact of new borrowing to finance infrastructure investment on debt} sustainability hinges critically on its impact on growth. A range of studies generally finds a positive impact of public investment on growth, operating not only through a direct impact on economic activity, but also through spillover effects on private investment. In a multicountry study, Burnside and Collier (1997) found that a sustained increase in grant-financed investment by one percent of GDP raised real GDP growth in low-income countries with good policy implementation on a sustained basis by about 0.4 percentage points. ${ }^{6} \mathrm{~A}$ World Bank study focusing on Mozambique drew a comparable conclusion. ${ }^{7}$ It suggested that an increase in grant-financed investment by one percent of GDP increased growth by 0.25 percentage points. A cross-country Fund study largely confirms these estimates and, for Mozambique, concluded that a one percent of GDP increase in public infrastructure investment would raise output growth by 0.5 percentage points. ${ }^{8}$ How public investment is used also matters. For example, Aschauer (1989) found that investing in public infrastructure yields supernormal returns. ${ }^{9}$ Similarly, Easterly and Rebelo (1993) found that investment in transportation and communications is consistently correlated with growth. ${ }^{10}$ Hulton (1996), as

\footnotetext{
${ }^{5}$ Specific commitments include that the authorities complete their first own semiannual debt sustainability analysis by end-September 2010 and develop a multi-year debt strategy by end-November 2010. In these endeavors, they will benefit from Bank and Fund technical assistance; a Medium-Term Debt Strategy (MDTS) technical assistance mission is scheduled for June 2010.

${ }^{6}$ Burnside, Craig, and David Dollar, 1997. "Aid Spurs Growth in a Sound Policy Environment." Finance and Development, December 1997.

${ }^{7}$ Benito-Spinetto, Maria Teresa, and Peter G. Moll, 2005. "Macroeconomic Developments, Economic Growth and Consequences for Poverty." (Background paper for the Mozambique 2005 Country Economic Memorandum). February 2005.

${ }^{8}$ Vitek, Francis, forthcoming IMF Working Paper, 2010.

${ }^{9}$ Aschauer, D., “Is public expenditure productive?”. Journal of Monetary Economics, 1989.

${ }^{10}$ Easterly W. and S. Rebelo, "Fiscal Policy and Economic Growth". Journal of Monetary Economics, December 1993.
} 
well as Aschauer (2000), identified that a growth penalty is associated with the ineffective use of public infrastructure investment. ${ }^{11}$

13. However, the growth impact of public investment on growth is also affected by how it is financed. Costly financing can reduce the impact because of negative spillovers on fiscal and external balances and private investment. This is particularly pertinent when, as determined by Vitek (2010) and Aschauer (2000), private investment can have a larger impact on growth than public investment. Indeed, Aschauer (2000) found that external debt financing of public investment could reduce the impact on growth, depending on the quality and effective use of the investment, as well as the financing costs. These considerations emphasize the importance of using costly external financing exclusively for infrastructure projects with a high rate of return, based on feasibility studies to carefully assess projects.

\section{Borrowing and growth impact assumptions}

14. The government is preparing impact studies and will initially focus on projects with a presumed high rate of return on growth and for which the financial viability is assured. The government plans to undertake infrastructure investment financed by nonconcessional borrowing over the medium term ranging between $1 \frac{1}{2}$ and 3 percent of GDP and averaging about 2 percent of GDP per year (US\$300 million from 2011 to 2013 then falling to US\$250 million by 2015). The need for such investment is likely to persist, and the projections incorporate continued nonconcessional borrowing at around 1 percent of GDP.

\section{The growth impact projections for the DSA are broadly in line with recent} studies, as noted above. In line with these findings, this investment is expected to raise real GDP growth by about 1 to $1 \frac{1}{2}$ percentage point over the next few years, with limited spillover effects into the longer term. The rate of return of further investment can be expected to fall, and the investment beyond the medium term is conservatively projected to raise real GDP growth by 0.3 percentage points.

\section{The projections incorporate borrowing by the central government on} concessional and nonconcessional terms. Central government borrowing for its own budgetary spending is assumed to be on IDA and AfDB terms. The grant element on this borrowing averages about 47 percent over the projection period. The projections also incorporate a limited amount of borrowing on nonconcessional terms. The investment projects and the financing modalities are still being finalized, but are currently expected to be mainly financed by sovereign borrowing or through loans mediated by official bilateral creditors (such as the Portuguese credit line) that would be on-lent to implementing SOEs. Accordingly, such nonconcessional borrowing is assumed to have a 10-year maturity, with one year of grace and an interest rate of 5 percent.

\footnotetext{
${ }^{11}$ Hulten, C.R. "Infrastructure Capital and Economic Growth: How Well You Use It May Be More Important than How Much You Have". NBER Working Paper No. 5847, December 1996.
} 


\section{Box 1. Macroeconomic Assumptions 2010-30}

The medium-term assumptions in the baseline scenario for 2010-30 are consistent with the medium-term macroeconomic framework underlying the authorities' request for a successor PSI and with the preliminary outline of the government's updated medium-term development plan.

Real GDP growth is projected to approach 8 percent over the next few years and stabilize around $71 / 2$ percent in the longer term. This includes the impact of higher infrastructure investment raising growth by 1 to $1 \frac{1}{2}$ percentage points in the medium term and by about $1 / 3$ percentage points in the longer term. This represents a deceleration from the annual average above 8 percent over the past decade.

Consumer price inflation is projected to stabilize around $5 \frac{1}{2}$ percent over the forecast period.

External financing. Mozambique is expected to remain reliant on aid flows for the foreseeable future, but this reliance is expected to decline. The grant-equivalent of total external financing is projected to fall from an average of over 11 percent of GDP during 2010-15 toward 7 percent of GDP by the end of the forecast period, in part reflecting a shift in the composition toward loan financing. Concessional borrowing through the budget is projected to trend down from 3.8 percent of GDP in the medium term to 3.4 percent in the longer term. All IDA financing is expected to be through loans. Public sector borrowing, including nonconcessional borrowing, is projected to rise from an annual average of around 5 percent of GDP during 1999-2009 to over 7 percent of GDP during 2010-15, declining toward $4 \frac{1}{2}$ percent of GDP thereafter.

Growth of exports of goods and services is projected to slightly accelerate from about 11 percent per year over 2010-15 to over 12 percent thereafter. This is largely driven by strong growth prospects for megaproject exports from the natural resource sector, for which investment is relatively advanced. Other exports are assumed to increase in line with import demand growth in Mozambique's trade partners.

Import growth is projected to remain steady around 10 percent per year in the medium term, then accelerating to about 11 percent. The strong import growth is driven by both private and public capital inflows. Other imports are assumed to grow at the rate of real GDP growth.

The noninterest current account deficit after grants is projected to widen from about 10 percent of GDP in 2009 to about 12 percent in the medium term because of the increase in public borrowing, as well as high private capital inflows. Beyond the medium term, private capital inflows are expected to rise relative to GDP, offsetting declining public borrowing. The noninterest current account deficit is projected to narrow toward 9 percent of GDP in the longer term, largely because of gains in the trade balance on goods and services.

Fiscal revenues are expected to rise from about 18 percent of GDP in 2009 to about 20 percent of GDP in 2015, largely reflecting a 0.5 percent of GDP annual revenue effort on account of improved revenue administration and a broadening tax base. Over time, nontax revenues from natural resource exploitation, particularly megaprojects, could make a growing contribution to the budget, but the increase of the overall revenue effort is conservatively projected to slow somewhat after 2015. Nevertheless, total revenue is projected to reach about 22 percent of GDP by the end of the forecast period, close to Mozambique's potential tax ratio, as estimated by a number of studies. ${ }^{1}$

The domestic primary balance is assumed to remain steady under 4 percent of GDP, with domestic financing between $1 / 2$ and 1 percent of GDP. Primary spending is projected to rise to nearly 35 percent of GDP in 2015 because of the increase in externally-financed investment, but then levels off to around 31 percent of GDP as external financing declines and debt service payments increase.

${ }^{1}$ See, for example, IMF, 2007, "Mozambique: Evaluation of the Post-Reforms Tax System”. 


\section{External Debt Sustainability Analysis}

\section{Under the baseline scenario, all debt indicators remain well below their} respective thresholds, including in the longer term (Table 2 and Figure 1). However, the debt indicators rise significantly towards their respective thresholds over the next five years, as the authorities make use of the already contracted Portuguese credit lines and step up their borrowing on nonconcessional terms to address the country's infrastructure gap.

- $\quad$ PV of debt: The PV of PPG external debt is projected to rise from 17 percent of GDP in 2009 to about 31 percent in 2015, still noticeably below the relevant debt burden threshold of 40 percent. It would then decline below 25 percent by 2030 . In terms of exports, the PV of PPG debt increases from 67 percent in 2009 to about 112 percent by 2015 - against a threshold of 150 percent — before falling to 68 percent by 2030 . Relative to government revenues, with a debt burden threshold of 250 percent, the PV of PPG debt would rise from 94 percent in 2009 to 154 percent in 2015, before declining to 104 percent by 2030 .

- Debt service: Debt service on PPG external debt would rise from nearly 2 percent of exports in 2009 to $7 \frac{1}{2}$ percent in 2016 before decreasing towards 4 percent by 2030 , thus remaining well below the 20 percent threshold. Debt service on PPG external debt would rise from below 3 percent of fiscal revenues in 2009 to over 11 percent in 2016 before falling towards 6 percent by 2030 .

18. The debt sustainability indicators are sensitive to shocks (Table 3 and Figure 1). ${ }^{12}$ The analysis suggests that the threshold for the PV of debt-to-GDP would be temporarily and marginally breached under a 30 percent depreciation of the exchange rate versus the U.S. dollar (B6) as well as under the combination shock (B5). The stress tests also suggest a heightened vulnerability to adverse export developments (B2). Under the standard export shock, the PV of debt-to-exports ratio reaches 190 percent by 2015, thus exceeding the relevant threshold. However, this shock is extreme as it is based on a standard deviation of exports receipts largely driven by the exceptional circumstances faced in 2009. Export receipts fell sharply in 2009 , mainly because aluminum prices fell by nearly half, and the standard export shock would have implausibly imposed an additional price drop of similar magnitude to the baseline. A modified export shock was designed to capture the historical volatility over the past two decades of prices for aluminum, which accounts for roughly half of Mozambique's export proceeds. Under this modified test, the PV of debt-to-exports ratio reaches, but not exceeds, the relevant threshold. Mozambique's export volatility is expected to decline over the medium term, as its export base will become more diversified. Such

\footnotetext{
${ }^{12}$ The year 2000 is excluded from the stress tests relying on historical data, as macroeconomic performance was skewed by very severe floods and because of large breaks in the data series for the national accounts and balance of payments.
} 
diversification would mainly come from the natural resource sector, as projects are underway or planned to expand electricity, coal, minerals (e.g., titanium) and possibly oil exports.

\section{The debt sustainability indicators are also sensitive to a recurrence of past} macroeconomic circumstances. In this historical scenario (A1), the PV of debt relative to GDP approaches the relevant PV of debt-to-GDP threshold, but remains below it. However, this scenario does not take into account the significant structural changes in the Mozambican economy in the post-civil war period and the considerable improvements in Mozambique's macroeconomic policy environment under successive Fund-supported programs, all of which make a recurrence of the past economic performance unlikely. Among other things, there was a shift in the structure of the economy, as large private capital inflows in the early years of the decade in the natural resources sector subsequently supported a surge in exports and a sharp fall in the current account deficit. Significant donor support helped bolster economic development. On the policy side, the authorities adopted a tighter fiscal and monetary policy stance that helped bring inflation to single digits over time and provided more room for private sector credit. This was also accompanied by exchange rate liberalization and important structural reforms that enhanced the efficiency of the economy. Overall, key economic indicators became less volatile during the period.

\section{The external debt indicators would deteriorate, but remain below their} respective thresholds, if nonconcessional resources are not used productively. ${ }^{13}$ In this high investment-low growth scenario (A3), real GDP growth would remain between $6 \frac{1}{2}$ and 7 percent, or about 1 to $1 \frac{1}{2}$ percentage point below the baseline in the medium term and about $1 / 2$ percentage points in the longer term. This scenario assumes that foreign financing and related spending would remain unchanged relative to the baseline in nominal terms. However, lower domestic revenues generate higher financing requirements that are met by additional external borrowing on commercial terms. To meet the additional external debt service obligations, the government is assumed to reduce domestic primary spending relative to the baseline in nominal terms. By the end of the forecast period, the domestic primary balance deteriorates by about $1 \frac{1}{2}$ percent of GDPcompared to the baseline and the additional financing rises to about 3 percent of GDP.

\section{Public Sector Debt Sustainability}

\section{The evolution of the public debt indicators (including domestic debt) mirrors that of the external indicators because of the predominance of external debt} (Table 4 and Figure 2). This medium-term increase in public debt reflects the temporary surge in public investment financed by external borrowing on nonconcessional terms. However, over the longer term, the public debt stock projections also include a marginal

\footnotetext{
13 This scenario maintains the baseline's assumptions regarding the exchange rate and public external borrowing in U.S. dollar terms.
} 
increase in domestic debt from about 3 percent of GDP at end-2009 to 4 percent of GDP in 2030 that should not affect the availability of credit to the private sector.

\section{Public debt indicators will develop as follows:}

- Mozambique's public debt obligations are expected to rise from 29 percent of GDP at end-2009 to 48 percent of GDP in 2015 and then decline towards 42 percent of GDP by 2030 .

- $\quad$ Similarly, the PV of public debt is projected to rise from 20 percent of GDP at end2009 to over 35 percent of GDP in 2015 before trending back down to 29 percent of GDP by 2030 .

- The evolution of the PV of debt and of debt service relative to revenues (including grants) is similar.

23. The large proportion of external debt makes the public debt burden vulnerable to the same set of shocks as external debt (Table 5). There are, however, some additional risks related to the accumulation of domestic financing. The stress tests indicate that public sector debt ratios are most vulnerable to an increase in other debt-creating flows (B5), to a one-time depreciation of the exchange rate (B4), and also to temporarily lower GDP growth (B1). The debt indicators rise noticeably in the long run when the primary deficit is held unchanged from the high level in 2010 that reflected the easing of the fiscal policy stance during the recent global crisis (A2). This emphasizes the importance of now reversing this policy stance, which the authorities intend to pursue under their successor PSI. Consistent with the program, the primary deficit is projected to temporarily increase by about $1 \frac{1}{2}$ percent of GDP from 2009 to 2011 because ofthe temporary increase in externallyfinanced investment, but the domestic portion of the balance is projected to improve by nearly 1 percent of GDP between 2009 and 2015.

\section{VIEWS OF THE AUTHORITIES}

24. The authorities are in broad agreement with the conclusions. A preliminary draft of the DSA and, in particular, the implications of scaling up infrastructure investment financed by nonconcessional borrowing were extensively discussed with the authorities. While broadly agreeing with the findings, the authorities reiterated their intention to adopt a cautious approach to nonconcessional borrowing and ensure that such borrowing would exclusively be channeled to infrastructure projects with a high economic rate of return. In their view, such an approach would be consistent with their overriding objective of preserving their strong track record with respect to macroeconomic stability. Finally, as mentioned above, the authorities committed to strengthening their debt management and develop a medium-term debt strategy to be able to make informed borrowing decisions. These intentions have been anchored in their new PSI-supported economic program. 


\section{Conclusions}

25. In the staffs' view, Mozambique continues to face a low risk of debt distress. Its external debt levels are expected to remain below their indicative thresholds for debt distress. However, the government's plans to temporarily increase public investment financed by external borrowing on nonconcessional terms, in line with the Fund's revised Debt Limits Policy, will noticeably increase debt vulnerabilities, as debt ratios under the stress tests approach, and in some instances temporarily and marginally exceed, the relevant thresholds. Although Mozambique's public debt is expected to decline beyond the medium term, stress tests suggest vulnerabilities, mirroring the large share of external debt in total debt.

\section{This calls for a cautious approach with nonconcessional borrowing and resolve} to improve debt management capacity. Where possible, the authorities should continue to rely on concessional borrowing and grants to minimize future debt service, and any nonconcessional external financing of new projects ought to be considered case by case, based on economic return, impact on debt sustainability, and potential effects on the financing decisions of donors and concessional lenders. The authorities' commitments under the successor PSI, including with respect to the continued pursuit of prudent macroeconomic

policies and structural reforms to boost their debt management capacity, should be conducive to containing debt vulnerabilities. 
Table 2.: External Debt Sustainability Framework, Baseline Scenario, 2007-2030 1/

(In percent of GDP, unless otherwise indicated)

\begin{tabular}{|c|c|c|c|c|c|c|c|c|c|c|c|c|c|c|c|}
\hline & \multicolumn{3}{|c|}{ Actual } & \multirow{3}{*}{$\begin{array}{c}\text { Historical } \\
\text { Average } \\
2001-09 \\
\end{array}$} & \multirow{3}{*}{$\begin{array}{r}\text { Standard } \\
\text { Deviation } \\
2001-09 \\
\end{array}$} & \multicolumn{6}{|c|}{ Projections } & \multirow[b]{2}{*}{$2010-2015$} & \multirow{2}{*}{\multicolumn{3}{|c|}{$2016-2030$}} \\
\hline & & & & & & & & & & & & & & & \\
\hline & 2007 & 2008 & 2009 & & & 2010 & 2011 & 2012 & 2013 & 2014 & 2015 & Average & 2020 & 2030 & Average \\
\hline External debt (nominal) $1 /$ & 57.3 & 49.7 & 52.5 & 87.6 & 36.9 & 55.5 & 61.6 & 63.3 & 63.7 & 65.1 & 66.3 & 62.6 & 64.9 & 62.7 & 64.3 \\
\hline $\mathrm{o} /$ w public and publicly guaranteed (PPG) & 18.0 & 21.3 & 26.0 & 62.0 & 38.6 & 32.1 & 36.3 & 39.0 & 40.7 & 42.9 & 44.2 & 39.2 & 41.7 & 37.6 & 40.3 \\
\hline Change in external debt & -7.5 & -7.6 & 2.8 & -11.3 & 16.7 & 2.9 & 6.1 & 1.7 & 0.5 & 1.4 & 1.2 & 2.3 & 0.5 & -0.4 & -0.2 \\
\hline Identified net debt-creating flows & -2.8 & -4.5 & 3.5 & 0.2 & 7.6 & 1.4 & 2.1 & 3.2 & 3.2 & 2.6 & 2.1 & 2.4 & 1.4 & 1.4 & 1.8 \\
\hline Non-interest current account deficit & 7.9 & 9.6 & 10.4 & 10.9 & 3.7 & 12.1 & 11.6 & 12.0 & 11.6 & 11.0 & 10.7 & 11.5 & 9.9 & 9.2 & 9.8 \\
\hline Deficit in balance of goods and services & 9.8 & 14.1 & 18.7 & 14.4 & 4.4 & 19.1 & 17.7 & 17.5 & 17.6 & 17.3 & 17.3 & 17.8 & 15.5 & 10.8 & 14.2 \\
\hline Exports & 35.4 & 32.3 & 25.1 & 30.3 & 4.8 & 26.8 & 30.9 & 29.8 & 28.3 & 27.9 & 28.1 & 28.6 & 30.2 & 36.1 & 32.0 \\
\hline Imports & 45.2 & 46.5 & 43.8 & 44.8 & 3.2 & 45.9 & 48.6 & 47.3 & 46.0 & 45.2 & 45.4 & 46.4 & 45.7 & 46.9 & 46.2 \\
\hline Net current trans fers (negative $=$ inflow) & -7.4 & -8.6 & -7.8 & -7.4 & 3.2 & -7.8 & -8.5 & -8.3 & -8.2 & -8.2 & -8.2 & -8.2 & -6.9 & -5.4 & -6.4 \\
\hline $\mathrm{o} / \mathrm{w}$ official & -6.3 & -7.7 & -6.9 & -7.1 & 3.1 & -6.9 & -7.6 & -7.5 & -7.4 & -7.4 & -7.4 & -7.4 & -6.0 & -4.5 & -5.6 \\
\hline Other current account flows (negative $=$ net inflow) & 5.5 & 4.0 & -0.6 & 3.9 & 3.5 & 0.7 & 2.4 & 2.7 & 2.2 & 1.9 & 1.6 & 1.9 & 1.2 & 3.8 & 2.0 \\
\hline Net FDI (negative = inflow) & -5.3 & -5.9 & -8.9 & -5.5 & 2.5 & -9.0 & -6.8 & -6.1 & -5.8 & -5.9 & -6.1 & -6.6 & -6.4 & -5.9 & -6.1 \\
\hline Endogenous debt dynamics 2/ & -5.4 & -8.1 & 2.0 & -5.1 & 6.9 & -1.7 & -2.7 & -2.6 & -2.6 & -2.4 & -2.6 & -2.4 & -2.0 & -1.9 & -2.0 \\
\hline Contribution from nominal interest rate & 1.8 & 2.3 & 1.6 & 2.5 & 0.8 & 1.6 & 1.3 & 1.5 & 1.8 & 2.0 & 2.1 & 1.7 & 2.2 & 2.4 & 2.3 \\
\hline Contribution from real GDP growth & -4.2 & -3.2 & -3.2 & -7.9 & 5.5 & -3.3 & -4.0 & -4.2 & -4.4 & -4.5 & -4.7 & -4.2 & -4.2 & -4.3 & -4.3 \\
\hline Contribution from price and exchange rate changes & -3.0 & -7.2 & 3.6 & 0.2 & 10.6 & $\ldots$ & $\ldots$ & $\ldots$ & $\ldots$ & $\ldots$ & $\ldots$ & & $\ldots$ & $\ldots$ & \\
\hline Residual (3-4) 3/ & -4.8 & -3.1 & -0.6 & -11.5 & 17.1 & 1.5 & 4.0 & -1.5 & -2.8 & -1.3 & -0.8 & -0.1 & -0.9 & -1.8 & -2.0 \\
\hline $\mathrm{o} / \mathrm{w}$ exceptional financing & -1.8 & -0.2 & 0.0 & -9.9 & 13.3 & 0.0 & 0.0 & 0.0 & 0.0 & 0.0 & 0.0 & 0.0 & 0.0 & 0.0 & 0.0 \\
\hline PV of external debt 4/ & $\ldots$ & $\ldots$ & 43.3 & 43.3 & & 44.1 & 50.0 & 51.6 & 52.0 & 52.7 & 53.4 & 50.6 & 51.5 & 49.8 & 51.1 \\
\hline In percent of exports & $\ldots$ & $\ldots$ & 172.6 & 172.6 & & 164.2 & 161.7 & 173.1 & 183.4 & 188.9 & 190.4 & 176.9 & 170.9 & 137.9 & 160.7 \\
\hline PV of PPG external debt & $\ldots$ & $\ldots$ & 16.8 & 16.8 & & 20.7 & 24.7 & 27.3 & 28.9 & 30.5 & 31.3 & 27.2 & 28.3 & 24.7 & 27.1 \\
\hline In percent of exports & ... & ... & 66.9 & 66.9 & & 77.0 & 79.8 & 91.6 & 101.9 & 109.2 & 111.5 & 95.2 & 93.9 & 68.2 & 85.6 \\
\hline In percent of government revenues & $\ldots$ & $\ldots$ & 94.5 & 94.5 & & 112.1 & 131.8 & 142.4 & 146.9 & 152.5 & 154.0 & 139.9 & 134.6 & 103.8 & 124.3 \\
\hline Debt service-to-exports ratio (in percent) & 40.7 & 19.2 & 20.0 & 23.8 & 7.0 & 17.4 & 11.3 & 12.8 & 17.4 & 21.6 & 23.1 & 17.3 & 24.4 & 23.5 & 24.6 \\
\hline PPG debt s ervice-to-exports ratio (in percent) & 1.7 & 1.6 & 1.9 & 2.8 & 1.0 & 2.9 & 2.3 & 3.4 & 4.9 & 6.4 & 7.7 & 4.6 & 6.4 & 4.2 & 5.8 \\
\hline PPG debt service-to-revenue ratio (in percent) & 3.7 & 3.1 & 2.7 & 6.2 & 2.6 & 4.2 & 3.7 & 5.3 & 7.1 & 8.9 & 10.7 & 6.7 & 9.2 & 6.4 & 8.4 \\
\hline Total gross financing need (Billions of U.S. dollars) & 1.4 & 1.0 & 0.6 & 0.9 & 0.3 & 0.8 & 0.9 & 1.2 & 1.5 & 1.7 & 1.9 & 1.3 & 2.9 & 8.7 & 4.8 \\
\hline Non-interest current account deficit that stabilizes debt ratio & 15.5 & 17.2 & 7.6 & 22.2 & 17.8 & 9.1 & 5.5 & 10.3 & 11.2 & 9.6 & 9.5 & 9.2 & 9.3 & 9.6 & 10.1 \\
\hline \multicolumn{16}{|l|}{ Key macroeconomic assumptions } \\
\hline Real GDP growth (in percent) & 7.3 & 6.7 & 6.3 & 8.0 & 2.0 & 6.5 & 7.5 & 7.6 & 7.9 & 7.8 & 7.8 & 7.5 & 7.2 & 7.5 & 7.3 \\
\hline GDP deflator in US dollar terms (change in percent) & 4.9 & 14.4 & -6.8 & 2.2 & 9.0 & -2.4 & -2.1 & 5.2 & 5.3 & 3.0 & 0.7 & 1.6 & 3.0 & 2.9 & 2.9 \\
\hline Effective interest rate (percent) $5 /$ & 3.1 & 4.8 & 3.2 & 3.1 & 1.2 & 3.2 & 2.5 & 2.8 & 3.3 & 3.6 & 3.5 & 3.1 & 3.8 & 4.2 & 3.9 \\
\hline Growth of exports of G\&S (US dollar terms, in percent) & 3.7 & 11.8 & -23.2 & 16.7 & 18.4 & 11.2 & 21.2 & 9.1 & 8.1 & 9.4 & 9.2 & 11.4 & 10.6 & 13.4 & 12.3 \\
\hline Growth of imports of G\&S (US dollar terms, in percent) & 7.6 & 25.7 & -6.6 & 12.9 & 11.9 & 9.0 & 11.3 & 10.4 & 10.3 & 9.2 & 9.0 & 9.9 & 10.7 & 11.1 & 10.7 \\
\hline Grant element of new public sector borrowing (in percent) & $\ldots$ & $\ldots$ & $\ldots$ & $\ldots$ & $\ldots$ & 39.0 & 23.4 & 24.8 & 26.3 & 29.6 & 30.9 & 29.0 & 34.4 & 35.9 & 35.6 \\
\hline Government revenues (excluding grants, in percent of GDP) & 15.9 & 16.0 & 17.8 & 14.2 & 2.1 & 18.4 & 18.7 & 19.2 & 19.7 & 20.0 & 20.3 & 19.4 & 21.1 & 23.8 & 21.9 \\
\hline Aid flows (in Billions of US dollars) 7/ & 0.9 & 1.2 & 0.9 & 0.8 & 0.2 & 1.4 & 1.4 & 1.6 & 1.8 & 2.0 & 2.2 & 1.7 & 3.0 & 6.3 & 3.9 \\
\hline $\mathrm{o} / \mathrm{w}$ Grants & 0.8 & 0.9 & 0.9 & 0.6 & 0.2 & 0.9 & 1.0 & 1.1 & 1.3 & 1.4 & 1.5 & 1.2 & 2.0 & 3.9 & 2.5 \\
\hline $\mathrm{o} / \mathrm{w}$ Concessional loans & 0.2 & 0.2 & 0.0 & 0.2 & 0.1 & 0.5 & 0.4 & 0.5 & 0.5 & 0.6 & 0.6 & 0.5 & 1.0 & 2.5 & 1.4 \\
\hline Grant-equivalent financing (in percent of GDP) $8 /$ & $\ldots$ & $\ldots$ & $\ldots$ & & & 11.3 & 11.3 & 11.2 & 11.1 & 11.1 & 11.0 & 11.2 & 9.1 & 6.8 & 8.4 \\
\hline Grant-equivalent financing (in percent of external financing) 8/ & $\ldots$ & $\ldots$ & $\ldots$ & & & 74.2 & 64.4 & 66.0 & 67.7 & 70.9 & 72.4 & 69.3 & 73.9 & 71.0 & 73.6 \\
\hline \multicolumn{16}{|l|}{ Memorandum items: } \\
\hline Nominal GDP (Billions of US dollars) & 8.1 & 9.9 & 9.8 & 6.7 & 2.3 & 10.2 & 10.8 & 12.2 & 13.8 & 15.4 & 16.7 & 13.2 & 27.2 & 74.0 & 40.2 \\
\hline Nominal dollar GDP growth & 12.6 & 22.1 & -0.9 & 10.3 & 8.9 & 3.9 & 5.3 & 13.2 & 13.6 & 11.0 & 8.6 & 9.3 & 10.4 & 10.6 & 10.4 \\
\hline PV of PPG external debt (in Billions of US dollars) & & & 1.6 & & & 2.0 & 2.7 & 3.3 & 4.0 & 4.6 & 5.1 & 3.6 & 7.6 & 18.0 & 10.5 \\
\hline (PVt-PVt-1)/GDPt-1 (in percent) & & & & & & 4.0 & 6.6 & 6.4 & 5.5 & 4.2 & 3.4 & 5.0 & 2.5 & 2.4 & 2.4 \\
\hline
\end{tabular}

Sources: Country authorities; and staff estimates and projections.

1/ Includes both public and private sector external debt. Assumes the provision of debt relief by all bilateral creditors on comparable terms at the time of the HIPC completion point.

2/ Derived as $[\mathrm{r}-\mathrm{g}-\rho(1+\mathrm{g})] /(1+\mathrm{g}+\rho+\mathrm{g} \rho)$ times previous period debt ratio, with $\mathrm{r}=$ nominal interest rate; $\mathrm{g}=$ real GDP growth rate, and $\rho=$ growth rate of GDP deflator in U.S. dollar terms.

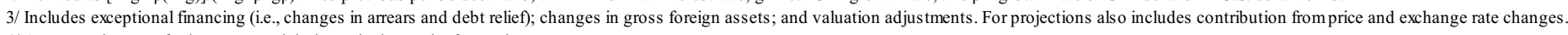

4/ Assumes that PV of private sector debt is equivalent to its face value.

5/ Current-year interest payments divided by previous period debt stock.

6/ Historical averages and standard deviations are generally derived over the years 2001-09, subject to data availability.

7/ Defined as grants, concessional loans, and debt relief.

8/ Grant-equivalent financing includes grants provided directly to the government and through new borrowing (difference between the face value and the PV of new debt). 


\begin{tabular}{|c|c|c|c|c|c|c|c|c|c|}
\hline & & & & & ections & & & & \\
\hline & 2010 & 2011 & 2012 & 2013 & 2014 & 2015 & 2020 & 2025 & 2030 \\
\hline PV of debt- & ratio & & & & & & & & \\
\hline Baseline & 20.7 & 24.7 & 27.3 & 28.9 & 30.5 & 31.3 & 28.3 & 26.1 & 24.7 \\
\hline A. Alternative Scenarios & & & & & & & & & \\
\hline A1. Key variables at their historical averages in 2010-2030 1/ & 20.7 & 24.2 & 27.2 & 29.2 & 30.5 & 31.3 & 33.6 & 34.6 & 35.6 \\
\hline A3. Alternative Scenario: No Growth Impact of NCB-Financed Investment & 20.7 & 25.1 & 28.6 & 31.0 & 33.0 & 35.1 & 36.3 & 37.3 & 39.3 \\
\hline B. Bound Tests & & & & & & & & & \\
\hline B1. Real GDP growth at historical average minus one standard deviation in 2011-2012 & 20.7 & 25.0 & 28.2 & 29.9 & 30.8 & 31.6 & 28.7 & 26.4 & 24.9 \\
\hline B2. Export value growth at historical average minus one standard deviation in 2011-2012 3/ & 20.7 & 27.5 & 33.2 & 34.3 & 34.9 & 35.4 & 31.0 & 27.4 & 25.1 \\
\hline B3. US dollar GDP deflator at historical average minus one standard deviation in 2011-2012 & 20.7 & 25.9 & 32.5 & 34.4 & 35.5 & 36.4 & 33.0 & 30.3 & 28.7 \\
\hline B4. Net non-debt creating flows at historical average minus one standard deviation in 2011-2012 4/ & 20.7 & 30.6 & 38.2 & 38.8 & 39.0 & 39.4 & 33.7 & 28.9 & 25.9 \\
\hline B5. Combination of B1-B4 using one-half standard deviation shocks & 20.7 & 30.6 & 41.2 & 41.9 & 42.2 & 42.6 & 36.5 & 31.3 & 28.2 \\
\hline B6. One-time 30 percent nominal depreciation relative to the baseline in 2011 5/ & 20.7 & 35.6 & 39.6 & 41.8 & 43.2 & 44.3 & 40.2 & 36.9 & 34.9 \\
\hline PV of de bt-to & ts rati & & & & & & & & \\
\hline Baseline & 77.0 & 79.8 & 91.6 & 101.9 & 109.2 & 111.5 & 93.9 & 79.9 & 68.2 \\
\hline A. Alternative Scenarios & & & & & & & & & \\
\hline A1. Key variables at their historical averages in 2010-2030 1/ & 77.0 & 78.4 & 91.3 & 103.1 & 109.2 & 111.5 & 111.6 & 106.1 & 98.4 \\
\hline A3. Alternative Scenario: No Growth Impact of NCB-Financed Investment & 77.0 & 81.3 & 95.9 & 109.5 & 118.4 & 125.1 & 120.2 & 114.5 & 108.8 \\
\hline B. Bound Tests & & & & & & & & & \\
\hline B1. Real GDP growth at historical average minus one standard deviation in 2011-2012 & 77.0 & 79.9 & 92.1 & 102.4 & 107.3 & 109.5 & 92.5 & 78.5 & 67.0 \\
\hline B2. Export value growth at historical average minus one standard deviation in 2011-2012 3/ & 77.0 & 101.5 & 130.7 & 141.8 & 146.3 & 147.8 & 120.6 & 98.4 & 81.5 \\
\hline B3. US dollar GDP deflator at historical average minus one standard deviation in 2011-2012 & 77.0 & 79.9 & 92.1 & 102.4 & 107.3 & 109.5 & 92.5 & 78.5 & 67.0 \\
\hline B4. Net non-debt creating flows at historical average minus one standard deviation in 2011-2012 4/ & 77.0 & 99.1 & 128.1 & 136.8 & 139.8 & 140.3 & 111.8 & 88.6 & 71.7 \\
\hline B5. Combination of B1-B4 using one-half standard deviation shocks & 77.0 & 106.9 & 135.0 & 144.4 & 147.7 & 148.2 & 118.3 & 93.9 & 76.2 \\
\hline B6. One-time 30 percent nominal depreciation relative to the baseline in $20115 /$ & 77.0 & 79.9 & 92.1 & 102.4 & 107.3 & 109.5 & 92.5 & 78.5 & 67.0 \\
\hline PV of debt-to & ue rati & & & & & & & & \\
\hline Baseline & 112 & 132 & 142 & 147 & 152 & 154 & 135 & 117 & 104 \\
\hline A. Alternative Scenarios & & & & & & & & & \\
\hline A1. Key variables at their historical averages in 2010-2030 1/ & 112 & 129 & 142 & 149 & 152 & 154 & 160 & 155 & 150 \\
\hline A3. Alternative Scenario: No Growth Impact of NCB-Financed Investment & 112 & 134 & 149 & 158 & 165 & 173 & 172 & 167 & 166 \\
\hline B. Bound Tests & & & & & & & & & \\
\hline B1. Real GDP growth at historical average minus one standard deviation in 2011-2012 & 112 & 134 & 147 & 152 & 154 & 156 & 136 & 118 & 105 \\
\hline B2. Export value growth at historical average minus one standard deviation in 2011-2012 3/ & 112 & 147 & 173 & 175 & 174 & 174 & 147 & 122 & 106 \\
\hline B3. US dollar GDP deflator at historical average minus one standard deviation in 2011-2012 & 112 & 139 & 170 & 175 & 178 & 179 & 157 & 136 & 121 \\
\hline B4. Net non-debt creating flows at historical average minus one standard deviation in 2011-2012 4/ & 112 & 164 & 199 & 197 & 195 & 194 & 160 & 129 & 109 \\
\hline B5. Combination of B1-B4 using one-half standard deviation shocks & 112 & 164 & 215 & 213 & 211 & 210 & 174 & 140 & 119 \\
\hline B6. One-time 30 percent nominal depreciation relative to the baseline in $20115 /$ & 112 & 190 & 206 & 213 & 216 & 218 & 191 & 165 & 147 \\
\hline Debt service- & rts rat & & & & & & & & \\
\hline Baseline & 2.9 & 2.3 & 3.4 & 4.9 & 6.4 & 7.7 & 6.4 & 5.1 & 4.2 \\
\hline A. Alternative Scenarios & & & & & & & & & \\
\hline A1. Key variables at their historical averages in 2010-2030 1/ & 2.9 & 2.2 & 3.4 & 5.0 & 6.5 & 7.7 & 6.8 & 5.9 & 5.5 \\
\hline A3. Alternative Scenario: No Growth Impact of NCB-Financed Investment & 2.9 & 2.3 & 3.5 & 5.2 & 7.1 & 9.0 & 10.3 & 10.7 & 10.9 \\
\hline B. Bound Tests & & & & & & & & & \\
\hline B1. Real GDP growth at historical average minus one standard deviation in 2011-2012 & 2.9 & 2.3 & 3.4 & 4.9 & 6.4 & 7.7 & 6.4 & 5.1 & 4.2 \\
\hline B2. Export value growth at historical average minus one standard deviation in 2011-2012 3/ & 2.9 & 2.6 & 4.3 & 6.3 & 8.0 & 9.5 & 8.4 & 6.5 & 5.2 \\
\hline B3. US dollar GDP deflator at historical average minus one standard deviation in 2011-2012 & 2.9 & 2.3 & 3.4 & 4.9 & 6.4 & 7.7 & 6.4 & 5.1 & 4.2 \\
\hline B4. Net non-debt creating flows at historical average minus one standard deviation in 2011-2012 4/ & 2.9 & 2.3 & 3.9 & 5.8 & 7.2 & 8.5 & 7.8 & 5.9 & 4.6 \\
\hline B5. Combination of B1-B4 using one-half standard deviation shocks & 2.9 & 2.5 & 4.1 & 6.1 & 7.6 & 9.0 & 8.2 & 6.2 & 4.9 \\
\hline B6. One-time 30 percent nominal depreciation relative to the baseline in 2011 5/ & 2.9 & 2.3 & 3.4 & 4.9 & 6.4 & 7.7 & 6.4 & 5.1 & 4.2 \\
\hline Debt service- 1 & tue ra & & & & & & & & \\
\hline Baseline & 4.2 & 3.7 & 5.3 & 7.1 & 8.9 & 10.7 & 9.2 & 7.4 & 6.4 \\
\hline A. Alternative Scenarios & & & & & & & & & \\
\hline A1. Key variables at their historical averages in 2010-2030 1/ & 4.2 & 3.6 & 5.3 & 7.2 & 9.0 & 10.7 & 9.7 & 8.6 & 8.3 \\
\hline A3. Alternative Scenario: No Growth Impact of NCB-Financed Investment & 4.2 & 3.8 & 5.4 & 7.5 & 9.9 & 12.4 & 14.7 & 15.5 & 16.6 \\
\hline B. Bound Tests & & & & & & & & & \\
\hline B1. Real GDP growth at historical average minus one standard deviation in 2011-2012 & 4.2 & 3.8 & 5.4 & 7.3 & 9.2 & 11.0 & 9.4 & 7.6 & 6.6 \\
\hline B2. Export value growth at historical average minus one standard deviation in 2011-2012 3/ & 4.2 & 3.7 & 5.6 & 7.8 & 9.5 & 11.3 & 10.2 & 8.0 & 6.8 \\
\hline B3. US dollar GDP deflator at historical average minus one standard deviation in 2011-2012 & 4.2 & 3.9 & 6.3 & 8.4 & 10.5 & 12.6 & 10.8 & 8.8 & 7.6 \\
\hline B4. Net non-debt creating flows at historical average minus one standard deviation in 2011-2012 4/ & 4.2 & 3.7 & 6.0 & 8.4 & 10.1 & 11.7 & 11.1 & 8.6 & 7.1 \\
\hline B5. Combination of B1-B4 using one-half standard deviation shocks & 4.2 & 3.8 & 6.5 & 9.1 & 10.9 & 12.8 & 12.0 & 9.3 & 7.7 \\
\hline B6. One-time 30 percent nominal depreciation relative to the baseline in $20115 /$ & 4.2 & 5.4 & 7.6 & 10.2 & 12.8 & 15.4 & 13.2 & 10.7 & 9.2 \\
\hline Memorandum item: & & & & & & & & & \\
\hline Grant element assumed on residual financing (i.e., financing required above baseline) $6 /$ & 26 & 26 & 26 & 26 & 26 & 26 & 26 & 26 & 26 \\
\hline
\end{tabular}

Sources: Country authorities; and staff estimates and projections.

1/ Variables include real GDP growth, growth of GDP deflator (in U.S. dollar terms), non-interest current account in percent of GDP, and non-debt creating flows.

2/ The stress test A2, borrowing on less favourable terms, has been dropped as it is not appropriate in this case. Given the commercial financing terms for the investment projects, the A2 scenario would yield unrealistic results, as marginal borrowing under this test is calculated on the average terms of new borrowing, therefore assuming harsher terms than Mozambique would face in the need to cover a financing gap.

3/ Exports values are assumed to remain permanently at the lower level, but the current account as a share of GDP is assumed to return to its baseline level after the shock (implicitly assumin an offsetting adjustment in import levels).

4/ Includes official and private transfers and FDI

5/ Depreciation is defined as percentage decline in dollar/local currency rate, such that it never exceeds 100 percent

6/ Applies to all stress scenarios except for A3 in which the terms on all new financing are on commercial terms. 
Figure 1. Mozambique: Indicators of Public and Publicly Guaranteed External Debt under Alternatives Scenarios, 2010-2030 1/
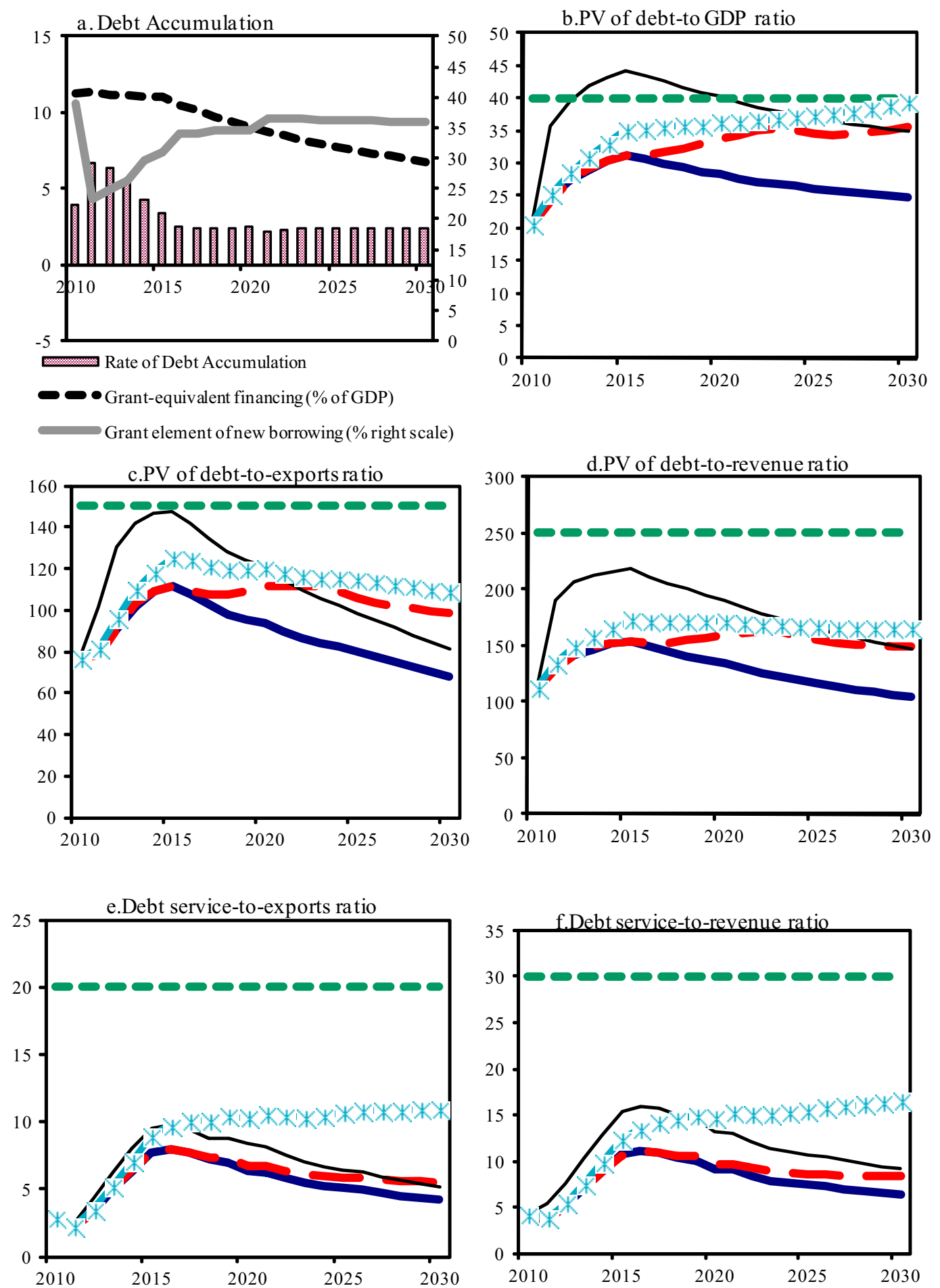

Sources: Country authorities; and staff estimates and projections.

Baseline Historical scenario $\longrightarrow$ Most extreme shock $1 / 0 \bullet \bullet$ Threshold $-m$ No Impact

1/ The most extreme stress test is the test that yields the highest ratio in 2020. In figure b. it corresponds to a One-time depreciation shock; in c. to a Exports shock; in d. to a One-time depreciation shock; in e. to a

Exports shock and in figure f. to a One-time depreciation shock 
Table 4.Mozambique: Public Sector Debt Sustainability Framework, Baseline Scenario, 2007-2030

(In percent of GDP, unless otherwise indicated)

\begin{tabular}{|c|c|c|c|c|c|c|c|c|c|c|c|c|c|c|c|}
\hline & \multicolumn{3}{|c|}{ Actual } & \multirow{2}{*}{$\begin{array}{c}2001-09 \\
\text { Average }\end{array}$} & \multirow{2}{*}{$\begin{array}{c}2001-09 \\
\text { Standard } \\
\text { Deviation }\end{array}$} & \multirow{2}{*}{$\begin{array}{c}\text { Estimate } \\
2010 \\
\end{array}$} & \multirow[b]{2}{*}{2011} & \multirow[b]{2}{*}{2012} & \multirow[b]{2}{*}{2013} & \multicolumn{3}{|c|}{ Projections } & \multirow[b]{2}{*}{2020} & \multirow[b]{2}{*}{2030} & \multirow[b]{2}{*}{$\begin{array}{l}2016-30 \\
\text { Average } \\
\end{array}$} \\
\hline & 2007 & 2008 & 2009 & & & & & & & 2014 & 2015 & $\begin{array}{l}2010-15 \\
\text { Average } \\
\end{array}$ & & & \\
\hline $\begin{array}{l}\text { Public sector debt } 1 / \\
\mathrm{o} / \mathrm{w} \text { foreign-currency denominated }\end{array}$ & $\begin{array}{l}21.9 \\
18.0\end{array}$ & $\begin{array}{l}25.4 \\
21.3\end{array}$ & $\begin{array}{l}29.3 \\
26.0\end{array}$ & $\begin{array}{l}66.4 \\
62.0\end{array}$ & $\begin{array}{l}38.1 \\
38.6\end{array}$ & $\begin{array}{l}35.1 \\
32.1\end{array}$ & $\begin{array}{l}39.2 \\
36.3\end{array}$ & $\begin{array}{l}42.4 \\
39.0\end{array}$ & $\begin{array}{l}44.4 \\
40.7\end{array}$ & $\begin{array}{l}46.8 \\
42.9\end{array}$ & $\begin{array}{l}48.4 \\
44.2\end{array}$ & $\begin{array}{l}42.7 \\
39.2\end{array}$ & $\begin{array}{l}46.4 \\
41.7\end{array}$ & $\begin{array}{l}42.0 \\
37.6\end{array}$ & $\begin{array}{l}45.2 \\
40.3\end{array}$ \\
\hline Change in public sector debt & -31.8 & 3.6 & 3.9 & -11.4 & 20.7 & 5.8 & 4.1 & 3.2 & 2.0 & 2.4 & 1.5 & 3.2 & -0.2 & -0.5 & -0.4 \\
\hline Identified debt-creating flows & -8.5 & 0.4 & 4.8 & -4.6 & 11.4 & 3.8 & 3.3 & 2.1 & 1.0 & 1.7 & 1.2 & 2.2 & 0.1 & -0.5 & -0.2 \\
\hline Primary deficit & 2.3 & 1.9 & 5.1 & 3.3 & 1.3 & 4.1 & 6.6 & 6.0 & 5.1 & 4.2 & 3.9 & 5.0 & 3.4 & 2.6 & 3.0 \\
\hline Revenue and grants & 25.2 & 25.4 & 27.4 & 23.1 & 2.4 & 27.2 & 28.1 & 28.4 & 28.9 & 29.2 & 29.5 & 28.5 & 28.4 & 29.0 & 28.7 \\
\hline of which: grants & 9.3 & 9.4 & 9.6 & 8.8 & 1.6 & 8.8 & 9.4 & 9.3 & 9.2 & 9.2 & 9.2 & 9.2 & 7.4 & 5.2 & \\
\hline Primary (noninterest) expenditure & 27.5 & 27.3 & 32.4 & 26.4 & 3.0 & 31.3 & 34.7 & 34.4 & 34.0 & 33.4 & 33.4 & 33.5 & 31.8 & 31.6 & 31.7 \\
\hline Automatic debt dynamics & -9.9 & -1.2 & 0.0 & -6.3 & 10.7 & -0.1 & -3.3 & -3.9 & -4.1 & -2.5 & -2.7 & -2.8 & -3.3 & -3.1 & -3.2 \\
\hline Contribution from interest rate/growth differential & -5.5 & -3.2 & 0.3 & -5.1 & 5.3 & -0.8 & -1.3 & -3.8 & -4.1 & -3.4 & -2.7 & -2.7 & -3.3 & -3.1 & -3.2 \\
\hline of which: contribution from average real interest rate & -1.9 & -1.8 & 1.9 & 1.1 & 7.7 & 1.0 & 1.1 & -1.0 & -1.0 & -0.2 & 0.7 & 0.1 & -0.2 & -0.1 & -0.1 \\
\hline of which: contribution from real GDP growth & -3.6 & -1.4 & -1.5 & -6.2 & 4.4 & -1.8 & -2.5 & -2.8 & -3.1 & -3.2 & -3.4 & -2.8 & -3.1 & -3.0 & -3.1 \\
\hline Contribution from real exchange rate depreciation & -4.4 & 2.0 & -0.4 & -1.2 & 8.4 & 0.7 & -2.0 & -0.1 & 0.0 & 0.9 & 0.0 & -0.1 & $\ldots$ & $\ldots$ & 0.0 \\
\hline Other identified debt-creating flows & -0.9 & -0.3 & -0.3 & -1.6 & 1.1 & -0.2 & 0.0 & 0.0 & 0.0 & 0.0 & 0.0 & 0.0 & 0.0 & 0.0 & 0.0 \\
\hline Privatization receipts (negative) & 0.0 & 0.0 & -0.2 & -0.3 & 0.6 & -0.1 & 0.0 & 0.0 & 0.0 & 0.0 & 0.0 & 0.0 & 0.0 & 0.0 & 0.0 \\
\hline Recognition of implicit or contingent liabilities & 0.0 & 0.0 & 0.0 & 0.0 & 0.0 & 0.0 & 0.0 & 0.0 & 0.0 & 0.0 & 0.0 & 0.0 & 0.0 & 0.0 & 0.0 \\
\hline Debt relief (HIPC and other) & -0.9 & -0.3 & -0.1 & -1.3 & 0.8 & -0.1 & 0.0 & 0.0 & 0.0 & 0.0 & 0.0 & 0.0 & 0.0 & 0.0 & 0.0 \\
\hline Other (specify, e.g. bank recapitalization) & 0.0 & 0.0 & 0.0 & 0.0 & 0.0 & 0.0 & 0.0 & 0.0 & 0.0 & 0.0 & 0.0 & 0.0 & 0.0 & 0.0 & \\
\hline Residual, including asset changes & -23.3 & 3.2 & -0.9 & -6.8 & 15.4 & 2.0 & 0.8 & 1.1 & 1.0 & 0.7 & 0.3 & 1.0 & -0.3 & -0.1 & -0.2 \\
\hline \multicolumn{16}{|l|}{ Other S ustainability Indicators } \\
\hline PV of public sector debt & 35.2 & 33.2 & 20.0 & 13.0 & 13.1 & 23.7 & 27.6 & 30.7 & 32.7 & 34.4 & 35.4 & 30.8 & 33.0 & 29.1 & 32.0 \\
\hline $\mathrm{o} / \mathrm{w}$ foreign-currency denominated & 31.3 & 29.0 & 16.8 & 8.6 & 13.4 & 20.7 & 24.7 & 27.3 & 28.9 & 30.5 & 31.3 & 27.2 & 28.3 & 24.7 & 27.1 \\
\hline $\mathrm{o} / \mathrm{w}$ external & 31.3 & 29.0 & 16.8 & 25.7 & 7.8 & 20.7 & 24.7 & 27.3 & 28.9 & 30.5 & 31.3 & 27.2 & 28.3 & 24.7 & 27.1 \\
\hline PV of contingent liabilities (not included in public sector debt) & 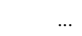 & $\ldots$ & & & & $\ldots$ & & $\ldots$ & $\ldots$ & $\ldots$ & $\ldots$ & & $\ldots$ & $\ldots$ & \\
\hline Gross financing need $2 /$ & 3.5 & 3.1 & 6.0 & 5.0 & 1.2 & 5.4 & 7.7 & 7.4 & 7.0 & 6.4 & 6.6 & 6.8 & 5.9 & 4.8 & \\
\hline $\mathrm{PV}$ of public sector debt-to-revenue and grants ratio (in percent) & 139.6 & 130.7 & 73.2 & 52.9 & 50.2 & 87.2 & 98.2 & 108.0 & 113.2 & 118.1 & 120.2 & 107.5 & 116.1 & 100.5 & 111.6 \\
\hline $\mathrm{PV}$ of public sector debt-to-revenue ratio (in percent) & 221.0 & 207.9 & 112.9 & 83.7 & 79.0 & 128.7 & 147.7 & 160.2 & 166.2 & 172.2 & 174.4 & 158.2 & 156.8 & 122.7 & 146.5 \\
\hline o/w external $3 /$ & 196.6 & 181.8 & 94.5 & 157.6 & 55.2 & 112.1 & 131.8 & 142.4 & 146.9 & 152.5 & 154.0 & 139.9 & 134.6 & 103.8 & 124.3 \\
\hline Debt service-to-revenue and grants ratio (in percent) 4/ & 4.8 & 4.8 & 3.5 & 7.6 & 3.3 & 4.9 & 4.0 & 4.9 & 6.6 & 7.7 & 9.0 & 6.2 & 8.8 & 7.3 & 8.5 \\
\hline Debt service-to-revenue ratio (in percent) $4 /$ & 7.6 & 7.6 & 5.4 & 12.4 & 5.5 & 7.3 & 6.0 & 7.3 & 9.8 & 11.2 & 13.1 & 9.1 & 11.8 & 8.9 & 11.2 \\
\hline Primary deficit that stabilizes the debt-to-GDP ratio & 34.1 & -1.7 & 1.2 & 11.2 & 19.9 & -1.7 & 2.5 & 2.8 & 3.1 & 1.8 & 2.4 & 1.8 & 3.6 & 3.2 & 3.4 \\
\hline \multicolumn{16}{|l|}{ Key macroeconomic and fiscal assumptions } \\
\hline Real GDP growth (in percent) & 7.3 & 6.7 & 6.3 & 8.0 & 2.0 & 6.5 & 7.5 & 7.6 & 7.9 & 7.8 & 7.8 & 7.5 & 7.2 & 7.5 & 7.3 \\
\hline Average nominal interest rate on forex debt (in percent) & 0.5 & 1.5 & 1.0 & 0.6 & 0.4 & 1.2 & 1.0 & 1.4 & 1.6 & 1.8 & 1.8 & 1.5 & 1.7 & 1.4 & 1.6 \\
\hline Average real interest rate on domestic debt (in percent) & 0.2 & 1.7 & 4.8 & 12.9 & 17.0 & 2.6 & 6.7 & 8.4 & 8.2 & 7.6 & $8.0^{\mathrm{r}}$ & 6.9 & 7.9 & $8.5^{\circ}$ & 8.3 \\
\hline Real exchange rate depreciation (in percent,+ indicates depreciation) & -10.4 & 13.2 & -1.7 & 0.1 & 12.8 & 2.7 & & & & & $\ldots$ & $\ldots$ & $\ldots$ & $\ldots$ & \\
\hline Inflation rate (GDP deflator, in percent) & 7.4 & 8.2 & 3.3 & 8.1 & 3.3 & 9.3 & 5.6 & 5.8 & 5.6 & 5.6 & 5.6 & 6.3 & 5.6 & 5.6 & 5.6 \\
\hline Growth of real primary spending (deflated by GDP deflator, in percent) & 0.1 & 0.1 & 0.3 & 0.1 & 0.1 & 0.0 & 0.2 & 0.1 & 0.1 & 0.1 & 0.1 & 0.1 & 0.1 & 0.1 & \\
\hline Grant element of new external borrowing (in percent) & & $\ldots$ & $\ldots$ & & & 39.0 & 23.4 & 24.8 & 26.3 & 29.6 & 30.9 & 29.0 & 34.4 & 35.9 & \\
\hline
\end{tabular}

Sources: Country authorities; and staff estimates and projections.

1/ Includes central government external PPG debt obligations and net domestic debt.

$2 /$ Gross financing need is defined as the primary deficit plus debt service plus the stock of short-term debt at the end of the last period.

3/ Revenues excluding grants.

f medium and long-term debt.

$5 /$ Historical averages and standard deviations are generally derived over years 2001-09, subject to data availability. 
Table 5.Mozambique: Sensitivity Analysis for Key Indicators of Public Debt 2010-2030

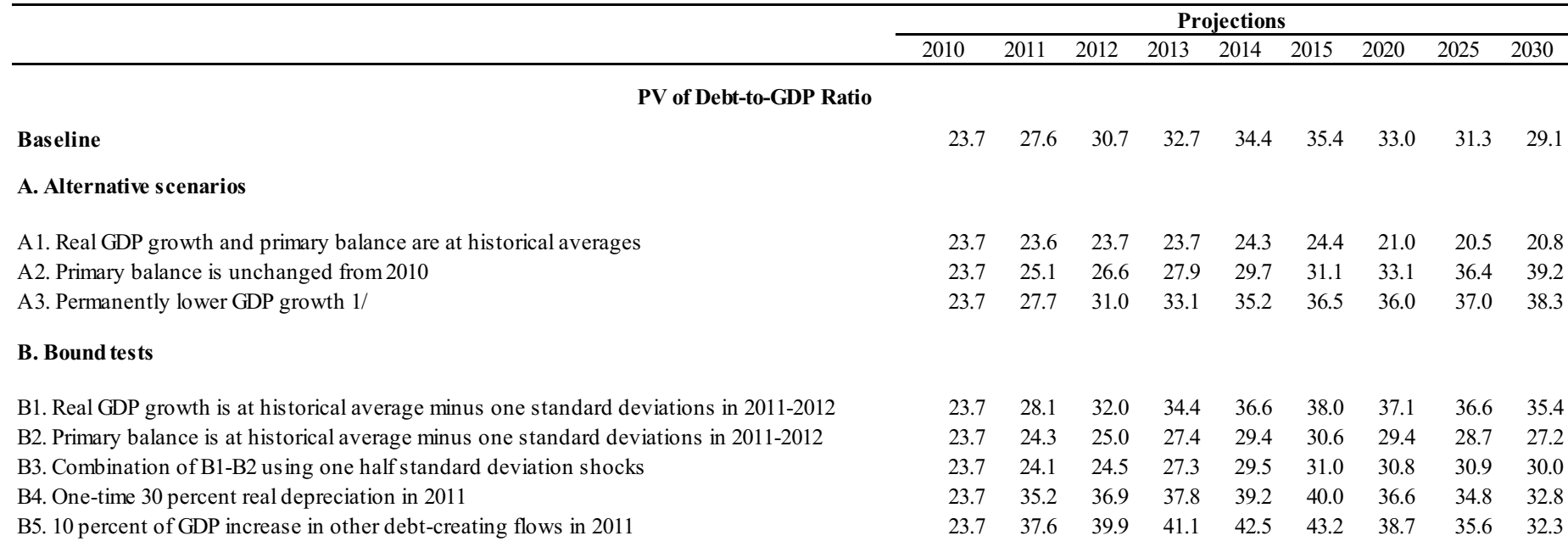

PV of Debt-to-Revenue Ratio 2/

\section{Baseline}

\section{A. Alternative scenarios}

A1. Real GDP growth and primary balance are at historical averages

A2. Primary balance is unchanged from 2010

A3. Permanently lower GDP growth 1/

\section{B. Bound tests}

B1. Real GDP growth is at historical average minus one standard deviations in 2011-2012

B2. Primary balance is at historical average minus one standard deviations in 2011-2012

B3. Combination of B1-B2 using one half standard deviation shocks

B4. One-time 30 percent real depreciation in 2011

B5. 10 percent of GDP increase in other debt-creating flows in 2011 $\begin{array}{lllllllll}87.2 & 98.2 & 108.0 & 113.2 & 118.1 & 120.2 & 116.1 & 110.0 & 100.5\end{array}$

$\begin{array}{rrrrrrrrr}87.2 & 83.9 & 83.1 & 82.1 & 83.1 & 82.7 & 74.0 & 72.3 & 71.9 \\ 87.2 & 89.3 & 93.4 & 96.5 & 101.9 & 105.6 & 116.3 & 127.8 & 135.1 \\ 87.2 & 98.5 & 108.8 & 114.6 & 120.3 & 123.3 & 125.9 & 129.1 & 131.0\end{array}$

$\begin{array}{rrrrrrrrr}87.2 & 99.6 & 111.7 & 118.2 & 124.5 & 128.0 & 129.7 & 128.0 & 121.8 \\ 87.2 & 86.4 & 87.9 & 95.0 & 100.9 & 103.9 & 103.6 & 100.7 & 93.8 \\ 87.2 & 85.4 & 86.0 & 94.2 & 100.9 & 104.8 & 108.2 & 108.2 & 103.4 \\ 87.2 & 125.1 & 129.9 & 130.9 & 134.3 & 135.5 & 128.6 & 122.2 & 113.2 \\ 87.2 & 133.7 & 140.2 & 142.3 & 145.7 & 146.4 & 136.3 & 124.9 & 111.3\end{array}$

Debt Service-to-Revenue Ratio 2/ $\begin{array}{lllllllll}4.9 & 4.0 & 4.9 & 6.6 & 7.7 & 9.0 & 8.8 & 8.2 & 7.3\end{array}$

\section{A. Alternative scenarios}

A1. Real GDP growth and primary balance are at historical averages

A2. Primary balance is unchanged from 2010

A3. Permanently lower GDP growth 1/

\section{B. Bound tests}

B1. Real GDP growth is at historical average minus one standard deviations in 2011-2012

B2. Primary balance is at historical average minus one standard deviations in 2011-2012

B3. Combination of B1-B2 using one half standard deviation shocks

B4. One-time 30 percent real depreciation in 2011

B5. 10 percent of GDP increase in other debt-creating flows in 2011

$\begin{array}{lllllllll}4.9 & 4.0 & 4.4 & 5.7 & 6.5 & 7.7 & 7.2 & 5.5 & 4.8\end{array}$

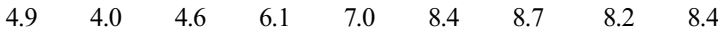

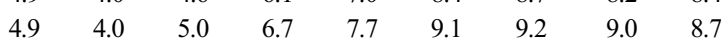

Sources: Country authorities; and staff estimates and projections.

1/ Assumes that real GDP growth is at baseline minus one standard deviation divided by the square root of the length of the projection period.

2/ Revenues are defined inclusive of grants. 
Figure 2. Mozambique: Indicators of Public Debt Under Alternative Scenarios, 2010-2030 1/
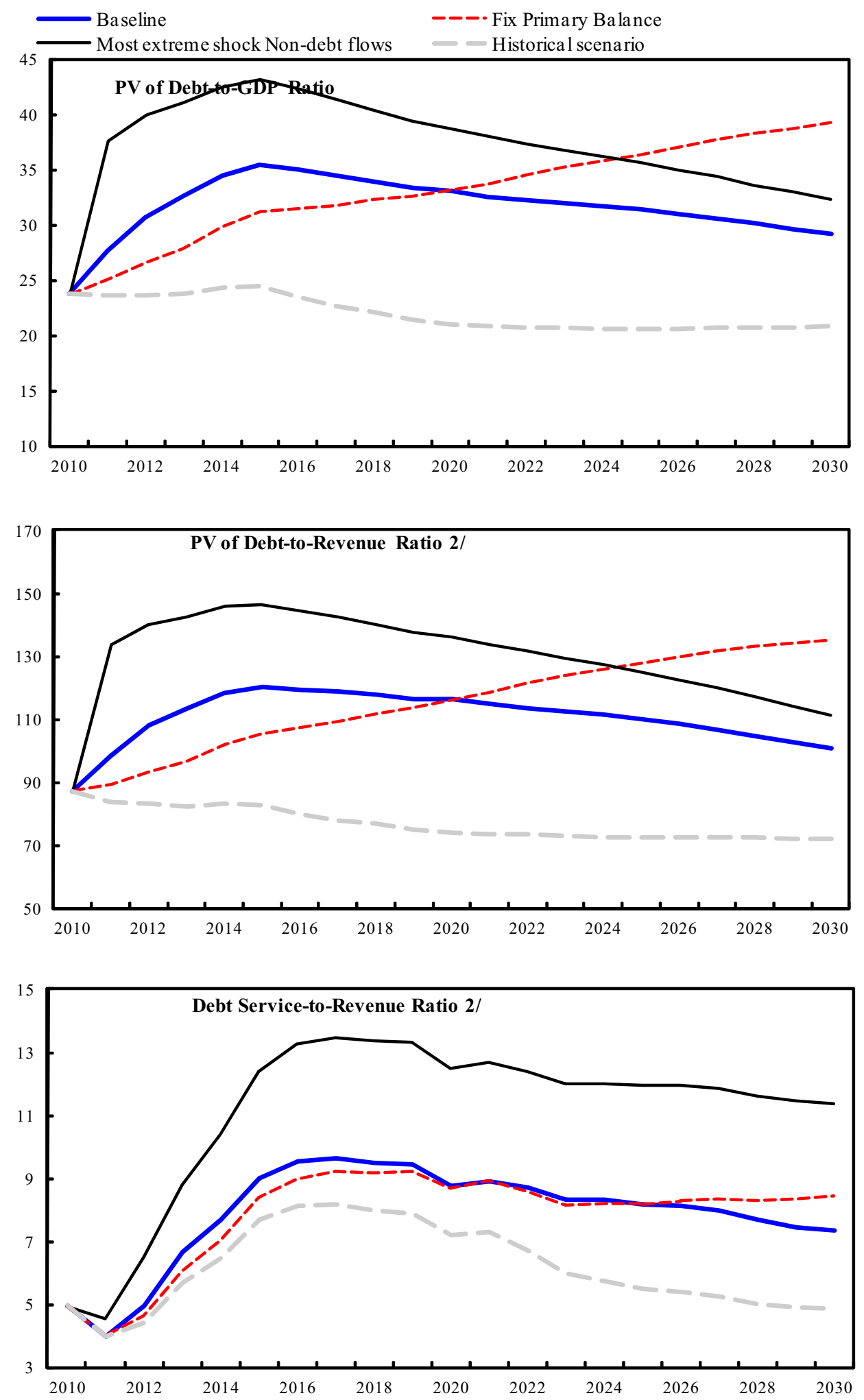

Sources: Country authorities; and staff estimates and projections.

1/ The most extreme stress test is the test that yields the highest ratio in 2020.

2/ Revenues are defined inclusive of grants. 


\title{
INTERNATIONAL MONETARY FUND
}

\section{REPUBLIC OF MOZAMBIQUE}

\section{Sixth Review Under the Policy Support Instrument, Second Review Under the Arrangement Under the Exogenous Shocks Facility, and Request for a Three-Year Policy Support Instrument- Informational Annex}

\author{
Prepared by the African Department \\ (In consultation with other departments)
}

May 27, 2010

I. Relations with the Fund ......................................................................................

II. World Bank-IMF Joint Management Action Plan ................................................

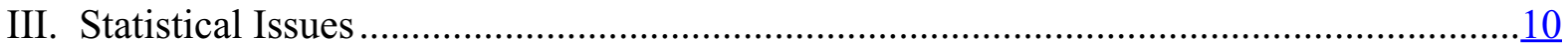




\section{MoZAmbiQUe: Relations With THE FUND}

(as of April 30, 2010)

I. Membership Status: Joined: September 24, 1984;

Article XIV

II. General Resources Account:

SDR Million

\%Quota

Quota

113.60

100.00

Fund holdings of currency

113.60

100.00

Reserve Position

0.01

0.01

III. SDR Department:

SDR Million

\%Allocation

108.84

100.00

Net cumulative allocation

108.66

99.83

Holdings

SDR Million

99.40

9.74
\%Quota

87.50

8.57

ECF Arrangements

\begin{tabular}{|c|c|c|}
\hline Type & $\begin{array}{c}\text { Date of } \\
\text { Arrangement }\end{array}$ & $\begin{array}{c}\text { Expiration } \\
\text { Date }\end{array}$ \\
\hline $\mathrm{ESF}$ & Jun 30,2009 & Jun $29, \overline{2010}$ \\
\hline $\mathrm{ECF}^{1}$ & Jul 06, 2004 & Jul 05, 2007 \\
\hline $\mathrm{ECF}^{1}$ & Jun 28, 1999 & Jun 28, 2003 \\
\hline
\end{tabular}

${ }^{1}$ Formerly PRGF.

VI. Projected Payments to Fund ${ }^{2}$

(SDR Million; based on existing use of resources and present holdings of SDRs):

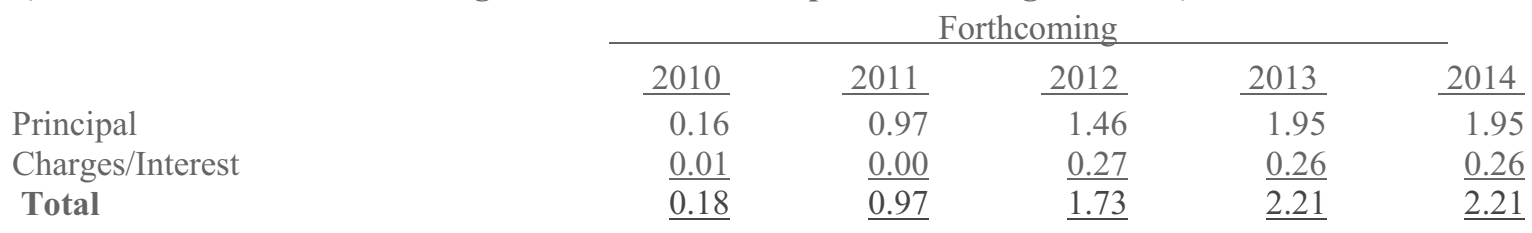

${ }^{2}$ When a member has overdue financial obligations outstanding for more than three months, the amount of such arrears will be shown in this section. 
VII. Implementation of HIPC Initiative:

I. Commitment of HIPC assistance

Decision point date

\begin{tabular}{|c|c|}
\hline Original & Enhanced \\
\hline ramework & Framework \\
\hline Apr 1998 & Apr 2000 \\
\hline $1,716.00$ & 306.00 \\
\hline 124.60 & 18.46 \\
\hline 93.17 & 13.73 \\
\hline
\end{tabular}

Assistance committed

by all creditors (US\$ Million) ${ }^{1}$

Of which: IMF assistance (US\$ million)

(SDR equivalent in millions)

Jun. 1999 Sep. 2001

Completion point date

II. Disbursement of IMF assistance (SDR Million)

Assistance disbursed to the member

$\begin{array}{rrr}93.17 & 13.73 & 106.90 \\ -- & 2.31 & 2.31 \\ 93.17 & 11.42 & 104.58 \\ -- & 1.10 & 1.10 \\ 93.17 & 14.83 & 108.00\end{array}$

Interim assistance

Completion point balance

Additional disbursement of interest income ${ }^{2}$

Total disbursements

93.17

14.83

Total

\footnotetext{
${ }^{1}$ Assistance committed under the original framework is expressed in net present value (NPV) terms at the completion point, and assistance committed under the enhanced framework is expressed in NPV terms at the decision point. Hence these two amounts can not be added.

${ }^{2}$ Under the enhanced framework, an additional disbursement is made at the completion point corresponding to interest income earned on the amount committed at the decision point but not disbursed during the interim period.
}

\section{Implementation of Multilateral Debt Relief Initiative (MDRI):}

I. $\quad$ MDRI-eligible debt (SDR Million) ${ }^{1} \quad 106.56$

Financed by: MDRI Trust $\quad 83.05$

Remaining HIPC resources $\quad 23.51$

II. Debt Relief by Facility (SDR Million)

\section{Eligible Debt}

$\begin{array}{lrrr}\text { Delivery Date } & \underline{\text { GRA }} & \underline{\text { PRGF }} & \underline{\text { Total }} \\ \text { January } 2006 & \text { N/A } & 106.56 & 106.56\end{array}$

${ }^{1}$ The MDRI provides 100 percent debt relief to eligible member countries qualified for the assistance. Grant assistance from the MDRI Trust and HIPC resources provide debt relief to cover the full stock of debt owed to the Fund as of end-2004 outstanding at the time the member qualifies for debt relief. 


\section{Safeguards assessment}

An update safeguards assessment of the Bank of Mozambique's (BM) was completed on January 11, 2010 for the ESF. The assessment found improvements in financial reporting practices following the implementation of IFRS. It noted vulnerabilities in the oversight mechanism for external and internal auditing, controls, financial reporting, and in BM legal structure. It recommended that the BM commission an external quality assurance review of the internal audit function. Staff will follow-up on progress in implementing the assessment's recommendations.

\section{Exchange arrangements}

Mozambique has a floating exchange system. Commercial banks may buy and sell foreign exchange to individual customers on a fully negotiable basis. The Bank of Mozambique introduced a foreign exchange auction system in January 2005. Foreign exchange transactions are conducted mainly bilaterally and there is no pre-established frequency for auctions.

Mozambique still avails itself of the transitional arrangements under Article XIV of the Fund Articles of Agreement, but has eliminated all Article XIV restrictions. It maintains, however, restrictions on the making of payments and transfers for current international transactions subject to Fund approval under Article VIII, as evidenced by: (i) the discretionary prior approval for remittances of family living expenses; (ii) the authorization for the purchase of foreign exchange in excess of US $\$ 5,000$ for certain transactions; (iii) the prohibition for the conversion of balances of nonresidents' domestic currency accounts into foreign currency or transfer abroad; (iv) the prohibition on advance payments for a service; and (v) the prohibition on advance payments for the import of goods. At the authorities' request, an Article VIII mission was conducted by LEG and PDR in March 2004. A new foreign exchange law was submitted to the Assembly in May 2007 and came into effect on March 11,2009 . Following issuance of implementation regulations, the authorities intend to accept their obligations under Article VIII sections 2, 3, and 4 of the Fund's Articles of Agreement.

\section{Article IV consultation}

In accordance with Decision No 12794-(02/76), as amended by Decision No 12854-(02/96), Mozambique is on a 24-month Article IV cycle due to the approval of a PSI in June 2007. The 2009 Article IV consultation was completed by the Executive Board on June 30, 2009 (Country Report No. 09/227).

In concluding the 2009 Article IV consultation, Executive Directors welcomed Mozambique's continued strong macroeconomic performance in 2008 despite a challenging external environment. They commended the authorities' flexible policy response to higher fuel and food import prices, which helped to mitigate the impact of these shocks. Directors noted that Mozambique remains vulnerable to the global economic slowdown and agreed that 
the country's strong track record of prudent macroeconomic policy implementation has provided room to ease fiscal and monetary policy in the near term. In the medium term, Directors underscored the importance of preserving macroeconomic stability and supported efforts to enhance domestic revenue mobilization and to improve public financial management. They welcomed the authorities' intention to limit recourse to domestic financing of the budget so as to preserve sufficient room for private sector credit growth. With respect to the overvaluation of the exchange rate in real effective terms, Directors suggested paying closer attention to a basket of currencies, which could help support Mozambique's competitiveness and economic diversification. Further progress in structural reforms and in developing and safeguarding the soundness of the banking system were seen as instrumental in supporting the business environment.

\section{Ex post assessment of performance under Fund-supported programs}

An ex post assessment (EPA) of Mozambique's performance under Fund-Supported Programs since 1987 was undertaken in December 2003 under the guidelines on assessments of countries with a longer-term program engagement. The EPA was circulated to the Executive Board on November 21, 2003 (Country Report No. 04/53).

Directors commended the authorities for their pursuit of sound macroeconomic policies and wide ranging structural reforms over the past fifteen years which contributed to strong growth of the economy, and a steady decline in poverty rates. Noting that despite considerable progress Mozambique remains a very poor and vulnerable country, Directors urged the authorities to persevere in their efforts to consolidate macroeconomic stability and accelerate and deepen structural reforms with a view to sustaining economic growth, encouraging employment creation, and further reducing poverty.

\section{FSAP participation and ROSCs}

A Financial Sector Assessment Program (FSAP) for Mozambique was undertaken during the first quarter of 2003. The related Financial Sector Stability Assessment was circulated to the Executive Board on November 19, 2003 (Country Report No. 04/52). An update to the FSAP took place in February 2009 and the related Financial Sector Stability Assessment circulated to the Board on June 19, 2009 (Country Report No. 10/12) A ROSC on fiscal transparency was issued on February 22, 2001. This ROSC was updated in the context of the 2002 Article IV consultation (Country Report No. 02/140) and the 2003 Article IV Consultation (Country Report No. 04/50). The ROSC on fiscal transparency was updated in May 2008. A Report on the Observance of Standards and Codes (ROSC) data module was prepared in June 2002 and issued on March 5, 2003. This data module was updated in August 2005. 


\section{Management's visit}

At the invitation of the authorities, Mr. Kato, Deputy Managing Director, visited Maputo, Mozambique in July 2005.The Managing Director visited Mozambique on August 2007 for a meeting with the African Consultative Group on Quotas, Voice, and Representation.

\section{Resident representative}

Mr. Felix Fischer has been the IMF's resident representative to Mozambique since March 14, 2006. 


\begin{tabular}{|c|c|c|c|c|}
\hline \multicolumn{5}{|c|}{$\begin{array}{l}\text { IMF Technical Assistance Provided to Mozambique } \\
\qquad(2006-10)\end{array}$} \\
\hline Departments & Timing & Form & Purpose & Counterparts \\
\hline Finance & February 2008 & Mission & Update of Safeguard Assessment & $\begin{array}{l}\text { Bank of } \\
\text { Mozambique }\end{array}$ \\
\hline \multirow[t]{14}{*}{ Fiscal Affairs } & April-May 2010 & Mission & Revenue Administration Reform & Ministry of Finance \\
\hline & April 2010 & Mission & $\begin{array}{l}\text { Public Financial Management } \\
\text { Reforms }\end{array}$ & Ministry of Finance \\
\hline & February 2010 & Mission & Tax Policy Review & Ministry of Finance \\
\hline & May 2009 & Mission & Tax Administration Reform & Ministry of Finance \\
\hline & April 2008 & Mission & $\begin{array}{l}\text { Public Financial Management } \\
\text { Reforms }\end{array}$ & Ministry of Finance \\
\hline & April-May 2008 & Mission & Revenue Administration Reform & Ministry of Finance \\
\hline & Oct.-Nov. 2007 & Mission & Tax Administration Inspection & Ministry of Finance \\
\hline & September 2007 & Mission & $\begin{array}{l}\text { Public Private Partnerships and } \\
\text { Fiscal Risks }\end{array}$ & Ministry of Finance \\
\hline & August 2007 & Peripatetic expert & Tax Policy and Administration & Ministry of Finance \\
\hline & August 2007 & Mission & $\begin{array}{l}\text { Fiscal ROSC Update and Public } \\
\text { Financial Management inspection }\end{array}$ & Ministry of Finance \\
\hline & April-May 2007 & Mission & Tax Administration Inspection & Ministry of Finance \\
\hline & April-May 2007 & Mission & Petroleum Fiscal Regime & $\begin{array}{l}\text { Ministry of Finance } \\
\text { Ministry of Mineral } \\
\text { Resources }\end{array}$ \\
\hline & December 2006 & Mission & Tax Administration & Ministry of Finance \\
\hline & March 2006 & Mission & Tax Policy Review & Ministry of Finance \\
\hline \multirow[t]{6}{*}{$\begin{array}{l}\text { Monetary and } \\
\text { Capital Markets }\end{array}$} & April 2010 & Mission & $\begin{array}{l}\text { Strengthening Monetary Policy } \\
\text { Formulation and Implementation }\end{array}$ & $\begin{array}{l}\text { Bank of } \\
\text { Mozambique }\end{array}$ \\
\hline & November 2009 & Mission & $\begin{array}{l}\text { Strengthening Monetary Policy } \\
\text { Formulation and Implementation }\end{array}$ & $\begin{array}{l}\text { Bank of } \\
\text { Mozambique }\end{array}$ \\
\hline & May 2009 & Mission & 2009 FSAP Follow up & $\begin{array}{l}\text { Bank of } \\
\text { Mozambique }\end{array}$ \\
\hline & February 2009 & Mission & $\begin{array}{l}\text { TA on Central Banking and } \\
\text { Monetary Policy Formulation }\end{array}$ & $\begin{array}{l}\text { Bank of } \\
\text { Mozambique }\end{array}$ \\
\hline & May 2008 & Mission & $\begin{array}{l}\text { Strengthening Monetary Policy } \\
\text { Formulation and Implementation }\end{array}$ & $\begin{array}{l}\text { Bank of } \\
\text { Mozambique }\end{array}$ \\
\hline & December 2007 & Mission & $\begin{array}{l}\text { Implementation of IFRS for } \\
\text { Central Bank Accounts. }\end{array}$ & $\begin{array}{l}\text { Bank of } \\
\text { Mozambique }\end{array}$ \\
\hline
\end{tabular}




\begin{tabular}{|c|c|c|c|c|}
\hline \multicolumn{5}{|c|}{$\begin{array}{l}\text { IMF Technical Assistance Provided to Mozambique } \\
\qquad(2006-10)\end{array}$} \\
\hline \multirow[t]{8}{*}{ Departments } & Timing & Form & Purpose & Counterparts \\
\hline & August 2007 & Mission & $\begin{array}{l}\text { Post-FSAP TA Assessment: } \\
\text { Banking supervision, Monetary } \\
\text { Policy and Operations }\end{array}$ & $\begin{array}{l}\text { Bank of } \\
\text { Mozambique }\end{array}$ \\
\hline & April 2007 & Short-term consultant & Banking Supervision & $\begin{array}{l}\text { Bank of } \\
\text { Mozambique }\end{array}$ \\
\hline & October 2006 & Mission & $\begin{array}{l}\text { Post-FSAP TA Assessment: } \\
\text { Banking supervision, Monetary } \\
\text { Policy and Operations }\end{array}$ & $\begin{array}{l}\text { Bank of } \\
\text { Mozambique }\end{array}$ \\
\hline & Feb-March 2006 & Mission & AML/CFT legislation & $\begin{array}{l}\text { Bank of } \\
\text { Mozambique }\end{array}$ \\
\hline & Jan-Feb 2006 & Short-term consultant & Monetary Policy Framework & $\begin{array}{l}\text { Bank of } \\
\text { Mozambique }\end{array}$ \\
\hline & Jan-Feb 2006 & Short-term consultant & Monetary Operations & $\begin{array}{l}\text { Bank of } \\
\text { Mozambique }\end{array}$ \\
\hline & January 2006 & Short-term consultant & Exchange Rate Management & $\begin{array}{l}\text { Bank of } \\
\text { Mozambique }\end{array}$ \\
\hline \multirow[t]{8}{*}{ Statistics } & February 2010 & Mission & Multitopic GDDS & $\begin{array}{l}\text { National Institute of } \\
\text { Statistics }\end{array}$ \\
\hline & $\begin{array}{l}\text { March-April } \\
2008\end{array}$ & Mission & National Accounts Statistics & $\begin{array}{l}\text { National Institute of } \\
\text { Statistics }\end{array}$ \\
\hline & February 2008 & Mission & Balance of Payments Statistics & $\begin{array}{l}\text { Bank of } \\
\text { Mozambique }\end{array}$ \\
\hline & December 2007 & Mission & Balance of Payments Statistics & $\begin{array}{l}\text { Bank of } \\
\text { Mozambique }\end{array}$ \\
\hline & November 2007 & Mission & Monetary and Financial Statistics & $\begin{array}{l}\text { Bank of } \\
\text { Mozambique }\end{array}$ \\
\hline & June-July 2006 & Mission & Consumer Price Statistics & $\begin{array}{l}\text { National Institute of } \\
\text { Statistics (INE) }\end{array}$ \\
\hline & $\begin{array}{l}\text { August } 2005- \\
\text { July } 2006\end{array}$ & Long-term consultant & National Accounts Statistics & $\begin{array}{l}\text { National Institute of } \\
\text { Statistics }\end{array}$ \\
\hline & July 2005 & Mission & Government Finance Statistics & $\begin{array}{l}\text { National Institute of } \\
\text { Statistics }\end{array}$ \\
\hline
\end{tabular}




\section{World Bank-IMF JoInt Management ACtion Plan}

\section{Mozambique: World Bank-IF Joint Management Action Plan}

\section{Title}

Products

A. Mutual information on relevant work

program in next 12 months

Bank work program

Updated poverty analysis using the 2008/09 household survey

August 2010

FSTAP project support to financial sector reforms

Ongoing

Financial Sector Strategy

TBC

Financial Sector Contingency Plan

TBC

Fund work program

First PSI Review

Second PSI Review and 2011 Article IV

September 2010

March 2011

December 2010

June 2011

\section{B. Requests for work program inputs with} summary justification

Bank request to the Fund

Fund request to the Bank

Updated Macro Framework data

PSI reviews

Board Chairman Summing up from PSI review discussion (or Assessment letter) not older than six-months

Updates on advancing structural reforms: procurement, decentralization, business environment, financial sector

October 2010, April 2011

October 2010, January 2011

June 2010 to June 2011

$\begin{array}{ll}\text { March } 2010 & \text { June } 2010 \\ \text { TBD } & \text { Sep-10 } \\ \text { TBD } & \text { November } 2010 \\ \text { TBD } & \text { October } 2010\end{array}$

PFM: update work plan for 2009-11 in light of findings from PEFA TBD and ROSC

PFM: continue to monitor consolidation and expansion of e- Ongoing

Ongoing SISTAFE.

Policy advice on Public Sector Salary Reforms (incl. pensions)

Ongoing 


\section{Mozambique: Statistical Issues}

\section{Assessment of Data Adequacy for Surveillance}

General: Data provision has some shortcomings, but is broadly adequate for surveillance. Despite the increase in budget resources allocated to the compilation of official statistics, continued high reliance on external funding raises concerns about the sustainability of the programs of the National Institute of Statistics (INE). The authorities are making efforts to improve the quality and timeliness of economic and financial data through participation in the Fund's General Data Dissemination System (GDDS) and in the external sector module of the GDDS Project for Anglophone African Countries (funded by the U.K. Department for International Development (DFID)). Weaknesses exist, particularly in the areas of national accounts, prices, and government finance statistics.

Real sector statistics: The national accounts are prepared by the INE in accordance with the 1993 System of National Accounts (1993 SNA). In August 2007, the INE released quarterly GDP estimates at constant prices covering 2000-07 for the first time, along with a revised annual GDP series for the period 1991-2006, with 2003 as the new base year. The authorities are working to strengthen quarterly national accounts compilation at current prices. The INE's new household income and expenditure survey and economic censuses leading to a new business registry still need to be incorporated to strengthen the national accounts. A revamped consumer price index for Maputo based on weights derived from the 2002-03 household survey was released in February 2006. A national index obtained by integrating the indices for Maputo, Beira, and Nampula was released in April 2006. Several issues remain outstanding, however, to correct probable downward bias caused by carry forward techniques for discontinued products, improve the housing market rent sample, and expand coverage to include Quelimane and Greater Maputo areas. There are insufficient sectoral labor market and employment data, and where available, they have limited coverage. A one-year labor market survey of the entire country, undertaken by INE in collaboration with the Labor Ministry, was launched in October 2004.

Government finance statistics: Government finance statistics (GFS) are not compiled using an internationally accepted statistical methodology and no staff has been identified to do so. A complete list of public sector entities is lacking. Work on a correspondence table between budgetary information and GFS needs to be completed. In addition, work on an integrated information system to capture completely stocks and flow information needs further development.

Monetary and financial statistics: A 2004 work plan was developed to implement the Monetary and Financial Statistics Manual (MFSM) and develop an integrated monetary database (IMD) to meet the needs of the Bank of Mozambique (BM), AFR, and STA. In 
November 2007 the IMD was completed and allows the derivation of accurate and timely monthly monetary statistics, while reducing BM's reporting burden.

Balance of payments: With assistance from STA, provided in the context of the GDDS regional project, the $\mathrm{BM}$ has made significant progress toward compiling and disseminating balance of payments (BOP) and international investment position (IIP) statistics that are fully aligned with the Balance of Payments Manual, fifth edition (BPM5). The BM has an adequate institutional framework for the compilation of BOP and IIP statistics. However, further strengthening of external sector statistics needs to focus on: strengthening information technology (especially to apply data warehouse and on-line analytical processing tools); excluding the effects of price and exchange rate fluctuations from reserve asset flows; applying a methodology (provided through STA technical assistance) to estimate reinvested profits and stocks of financial assets and liabilities held abroad by the nonfinancial public sector; improving business surveys; publishing methodological notes, in general, and more data covering the Reserves Template, foreign direct investment, goods trade and current transfers; and beginning the gradual process to implement the new Balance of Payments and International Investment Position Manual, sixth edition. Joint work with other institutions to improve the quality of external trade data, especially with regard to price and volume indices, also merits attention.

\section{Data Standards and Quality}

Mozambique commenced its participation in the General Data Dissemination System (GDDS) in November 2003; but has since then not updated much of its metadata.

In May 2005, an update of the June 2002 data module of the Report on the Observance of Standards and Codes (Data ROSC) was prepared. Improvements in the institutional environment and increased allocation of resources for the compilation of national accounts and balance of payments statistics aimed to address weaknesses in the prerequisites for the quality of the statistics. Methodological soundness, accuracy, and reliability of macroeconomic statistics began to show improvements as a result of these efforts.

\section{Reporting to STA}

Mozambique does not report fiscal data for publication in the IFS or the Government Finance Statistic Yearbook (GFSY). Mozambique now reports monthly monetary data to STA using the standardized reporting forms (SRFs). As a result, these enhanced data are being published in the International Financial Statistics (IFS) Supplement. In 2007, the BM started to compile and report comprehensive IIP data in the Balance of Payments Statistics Yearbook. 
Mozambique: Table of Common Indicators Required for Surveillance

(As of May 10, 2010)

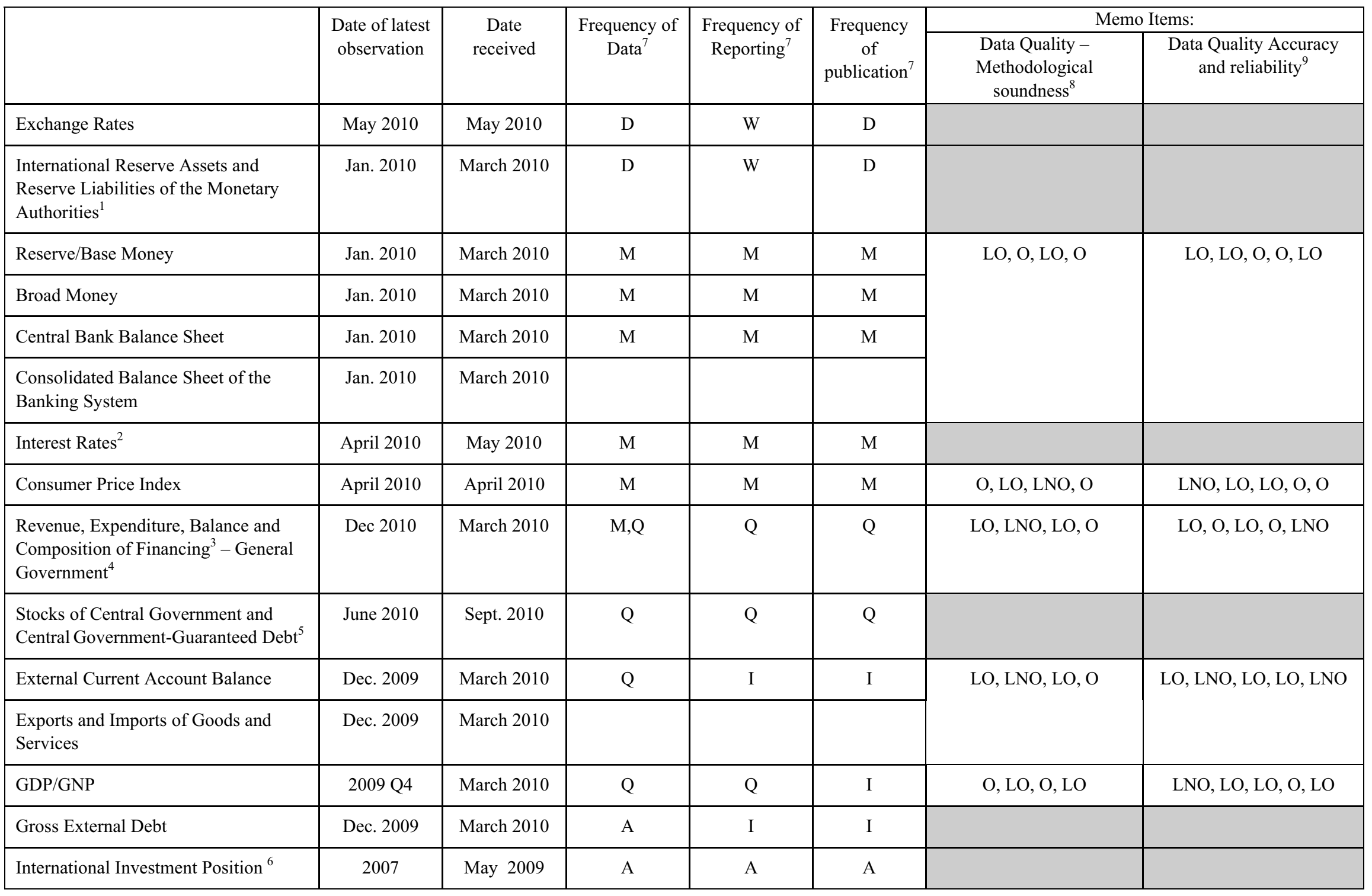

${ }^{1}$ Includes reserve assets pledged or otherwise encumbered as well as net derivative positions.

${ }^{2}$ Both market-based and officially determined, including discount rates, money market rates, rates on treasury bills, notes and bonds.

${ }^{3}$ Foreign, domestic bank, and domestic nonbank financing.

${ }^{4}$ The general government consists of the central government (budgetary funds, extrabudgetary funds, and social security funds) and state and local governments.

${ }^{5}$ Including currency and maturity composition.

${ }^{6}$ Includes external gross financial asset and liability positions vis-àvis nonresidents.

${ }^{7}$ Includes external gross financial asset and liability positions vis-àvis nonresidents.

${ }^{8}$ Daily (D), Weekly (W), Monthly (M), Quarterly (Q), Annually (A), and Not Available (NA)

${ }^{9}$ Reflects the assessment provided in the data ROSC or the Substantive Update for the dataset corresponding to the variable in each row. The assessment indicates whether international standards concerning concepts and definitions,

scope, classification/sectorization, and basis for recording are fully observed (O); largely observed (LO); largely not observed (LNO); not observed (NO); and not available (NA). 


\section{IMF Executive Board Approves New Three-Year PSI, Completes Second Review Under the ESF Arrangement and Approves US\$21 Million Disbursement for Mozambique}

The Executive Board of the International Monetary Fund (IMF) today completed the sixth and final review of Mozambique's economic performance under the Policy Support Instrument (PSI) and approved a new threeyear PSI.

The Board also completed the second review of Mozambique's performance under the Exogenous Shocks Facility (ESF), which will enable the third and final disbursement of SDR 14.2 million (about US\$21 million). The one-year, SDR 113.6 million (about US\$176 Million) ESF arrangement was approved on June 30, 2009 (see Press Release No. 09/247).

In completing the reviews, the Executive Board granted a waiver for the nonobservance of the end-December 2009 assessment criterion on the ceiling on reserve money.

The new PSI for Mozambique aims at accelerating economic development and reducing poverty while maintaining macroeconomic stability. The authorities aim to meet their development needs through a significant stepping up of public investment in infrastructure, which would necessitate broadening the financing options to also include nonconcessional borrowing.

The IMF's framework for PSIs is designed for low-income countries that may not need, or want, IMF financial assistance, but still seek IMF advice, monitoring, and endorsement of their policies. (see Public Information Notice No. 05/145). The previous PSI for Mozambique was approved by the Executive Board on June 18, 2007 (See Press Release No. 07/135).

Following the Executive Board's discussion on Mozambique, Mr. Murilo Portugal, Deputy Managing Director and Acting Chair, stated:

“Mozambique's macroeconomic performance in 2009 was resilient to the global economic crisis. Economic growth was stronger than envisaged and inflation remained low. The authorities' strong track record of prudent policy implementation provided the necessary room for policy easing, which helped mitigate the impact of the crisis. With the improved economic outlook, the authorities plan to start unwinding the policy easing in 2010. Significant headway was made in implementing key structural reforms, especially measures related to public financial management, tax policy and administration, the monetary policy framework, and financial sector supervision.

"Policies under the successor PSI will focus on enhancing economic growth to help Mozambique meet its development objectives while safeguarding macroeconomic stability. Embedded in a prudent fiscal and monetary policy stance, the PSI will support a sizeable increase in public sector investment, which will focus on, among others, the energy and transportation sectors, partially financed by nonconcessional external borrowing. Together with measures to improve the business environment, this is expected to help remove identified bottlenecks, so that the private sector can develop and play its intended role as an engine of growth. 
"The structural reform program emphasizes the need to make prudent and effective public investment and borrowing decisions. To this end, it focuses on strengthening the framework for investment planning and formulating and implementing a comprehensive debt strategy. The structural reform agenda will also continue to place emphasis on measures to strengthen public financial management, tax policy and administration, and the Bank of Mozambique's liquidity forecasting and management," Mr. Portugal added. 
ANNEX

\section{Recent Economic Developments}

Mozambique showed considerable resilience to the global crisis. Real GDP grew by $6 \frac{1}{3}$ percent in 2009, more than expected, owing to stronger performance of the construction, energy, and financial sectors. Large declines occurred in export receipts and private capital inflows, but the impact on external reserves was mitigated by the SDR allocation and by resources provided by the IMF through the Exogenous Shocks Facility.

As the global economy recovers, the economic outlook is expected to become more favorable. Real GDP growth should increase to $6 \frac{1}{2}$ percent in 2010 and 73/4percent by 2013 , largely because of new megaprojects in the natural resource sector, stepped-up public investment, and larger private sector participation. Continued prudent macroeconomic policies should keep inflation at around 6 percent on average over the medium-term, with a temporary spike in 2010 to above 9 percent following the gradual removal of the fuel subsidy. The government's investment plans should not fundamentally burden the external current account deficit and reserve levels. The current account deficit (after grants) and international reserves are expected to hover around 13 percent of GDP and above five months of imports over the next three years.

\section{Program Summary}

Mozambique's PSI aims at creating an environment conducive to strong growth, which is expected to also help ensure that more and more segments of the population will benefit from economic development. It envisages a limited expansion of nonconcessional external borrowing and domestic financing to boost infrastructure investment while maintaining a prudent fiscal policy stance that would keep the primary domestic deficit broadly unchanged. Monetary policy will be sufficiently tight to keep domestic demand pressures in check while providing ample room for private sector credit expansion.

Structural reforms will focus on improving the authorities' capacity for informed decision making, by promoting debt management, developing a borrowing strategy, and improving investment planning. It will also be important to continue the ongoing reforms with respect to public financial management, tax policy and administration, the monetary policy framework, and financial sector supervision.

The authorities' program will support an updated Poverty Reduction Strategy, which will be drafted involving with the private sector, civil society, and development partners, and finalized in the second half of 2010. 


\section{Statement by Moeketsi Majoro, Alternate Executive Director for Republic of Mozambique}

June 14, 2010

\section{Introduction}

1. My Mozambican authorities value the continued support by the Fund and the constructive policy dialogue with staff. They are committed to implementing reforms and to macroeconomic stability, as is evidenced by the overall satisfactory performance under the current PSI arrangement since its inception, and plan to further strengthen their engagement with the Fund under the successor PSI arrangement, for which they request approval by the Executive Directors.

2. With respect to the current program, all quantitative assessment/performance criteria through end-December 2009 were met, except for the one on reserve money, for which the authorities request a waiver. Reserve money exceeded the program ceiling because of the continued difficulty in predicting the demand for currency in circulation as a result of both the year-end seasonal surge and the structural shift from the expansion of banking services in the economy. In addition, there was progress in implementing structural reforms. In this regard, the authorities request Directors' support for the completion of the sixth review under the PSI and the second review under the ESF.

\section{Performance in 2009}

3. Mozambique has showed considerable resilience to the global economic crisis. Real GDP growth was much stronger than expected in 2009, which has been supported by construction, energy, and financial sectors. The global economic downturn triggered a large decline in export receipts and private external borrowing. The impact on external reserves was, however, mitigated by the SDR allocation and ESF resources, resulting in reserve coverage above 5 months of imports. The Government eased macroeconomic policies to contain spillover effects of the global crisis to the domestic economy. An accommodating monetary policy facilitated the substitution of foreign borrowing with a strong domestic private sector credit expansion. On the fiscal side, revenue performance kept the size of the automatic stabilizers small and resulted in a lower-than-expected domestic primary fiscal deficit.

\section{Objectives and policies under the new successor PSI arrangement and outlook}

\section{Objectives and outlook}

4. Economic performance has been strong and policy implementation has been successful under successive IMF-supported programs. Despite the relative strong GDP 
growth of the past decade, there are concerns that even though capital-intensive export sectors are growing, activity in the rest of the economy is below potential and labor-intensive growth is yet to be meaningfully exploited. In addition, although economic growth in Mozambique is high by regional standards, it has been trending down over the last few years. This slowed down progress in reducing poverty and improving development indicators. In this context, the authorities recognize the necessity of enhancing their efforts to sustainably raise and broaden the country's productive base.

5. Going forward, the authorities' focus will be on implementing policies to facilitate private sector development and sustainable economic growth. To that end, steps will be to enhance economic growth and rural development, in particular, with impact on the poor and disadvantaged through the creation and expansion of jobs; and acceleration of measures to improve the business environment and support to small and medium-sized enterprises. They will also seek to improve the selection process and prioritization of public investment in order to maximize the benefits associated with employment creation and poverty reduction and crowd-in private sector investment and production; and, further strengthen institutions to enable them reap the benefits from regional integration.

6. Consistent with these objectives and policies, and taking into account the political cycle in Mozambique, the Parliament has recently approved the Government's Five-Year Government Program for 2010-14. This program will be supplemented by an updated Poverty Reduction Strategy, which will be drafted, in a consultative process with all stakeholders, and finalized in the second half of 2010, taking into account the publication of the results of the Household Survey.

7. The economic outlook is expected to improve, as the global economic crisis wanes. Real GDP growth should accelerate to $6 \frac{1}{2}$ pecent in 2010 and above 7 percent by 2013 , facilitated largely by new megaprojects, stepped-up public investment in areas with an expected large growth dividend, and larger private sector participation. Continued prudent macroeconomic policies should keep inflation low over the medium-term, with a temporary spike in 2010 following the gradual removal of the fuel subsidy. Since the publication of the staff report, another fuel price increase has taken place, in line with program commitments. The authorities' investment plans are not anticipated to fundamentally burden the current account and, as a result, international reserve levels are expected to remain above 5 months of imports over the next three years.

8. The authorities are very thankful for the staff's collaboration at a Seminar held in Namaacha — south of Mozambique — to discuss Mozambique's medium-term economic policy priorities, as well as on the identification of options for financing the country's public investment program. This was a unique setting in terms of a wide participation of relevant decision-making individuals from the public sector and other stakeholders in the country. The authorities appreciate the fact that staff took time to participate in this retreat and to engage openly on policy options and exchange ideas, outside the normal review mission 
meetings.

\section{Fiscal policy}

9. The authorities aim to reduce the domestic primary deficit to 4.2 percent of GDP, in 2010. This will be attained through further improvements in the tax administration and current expenditure restraint. The 2010 budget law anticipates strong efficiency gains in tax administration that could boost the revenue-to-GDP ratio to $183 / 4$ percent of GDP. Furthermore, the authorities will base the budget execution on more conservative assumptions.

10. The authorities plan to step-up implementation of public investments in transport and electricity infrastructure by tapping domestic and international financing. They also plan to limit their annual recourse to domestic financing to less than 1 percent of GDP over the medium term. This would avoid crowding out the private sector. Concessional donor funding will remain the prime sources of financing in the foreseeable future. Nonetheless, given the size of the planned investment plans, the authorities are considering external nonconcessional borrowing averaging about 2 $\frac{1}{2}$ percent of GDP per year during the next three years. To support the growing level of external financing, they will finalize by end-2010 a comprehensive multi-year debt strategy, and will continue to strengthen their debt management, and in particular train staff to facilitate the semi-annual production of a debt sustainability analysis (DSA). The first such analysis will be completed and published by end-September 2010.

\section{Monetary and exchange rate policies}

11. The Bank of Mozambique (BM) is committed to implement prudent monetary and exchange rate policies aimed at containing inflation at single-digit on average over the medium term. These policies should help contain inflationary pressures emanating from the recent depreciation of the metical and the spillovers from higher domestic fuel prices due to the removal of fuel subsidy. In its monetary policy implementation, the BM will continue to pay close attention to the real effective exchange rate vis-àvis a broad basket of currencies. This should allow the exchange rate to adjust freely to evolving patterns of trade and financial flows while safeguarding international reserves.

12. The monetary policy transmission mechanism remains complex. In this regard, the BM will during the new PSI program (i) assess which inflation rate should be targeted and what core inflation rate should be used to assess inflationary conditions; (ii) enhance its monitoring, understanding, and capacity to project the monetary transmission mechanism; (iii) select and implement new monetary instruments to steer monetary conditions effectively; and (iv) improve its communications strategy with the public. 


\section{Structure reforms}

13. The authorities will continue with their reforms to improve the business environment to help raise Mozambique's growth potential, diversify exports, and stimulate new investment. In coordination with their development partners, they will work toward implementing a range of fast-track measures. This is expected to ease red tape, streamline the granting of business-related licenses, improve bankruptcy proceedings, and facilitate trading across borders.

14. In order to improve their statistical data compilation and dissemination, the authorities will focus on improving data quality related to the quarterly national accounts, consumer prices index, government finance statistics, and megaprojects. In the process, the authorities will request Fund's TA and advice. In particular, the National Statistics Institute (INE) will improve the calculation and the rebase of the CPI, and increase its geographical coverage. Furthermore, the authorities will ensure that INE's Strategic Plan is aligned with government's planning and budgeting cycle in order to influence policy development.

15. On PFM reforms, the authorities envisage a series of key measures in the short run comprising: (i) the implementation of SISTAFE system (e-SISTAFE) to more districts and other institutions, as well as on coverage of budget execution; (ii) the salary calculation in eSISTAFE; (iii) the integration of internal audit in e-SISTAFE system; (iv) improvement in aid management; (v) the strengthening of investment planning, limiting fiscal and quasifiscal risks, and maximizing economic benefits; (v) the improvements of the framework for public enterprises; and, (vi) the enhancement of the procurement systems.

16. Other reforms include: (i) reforming the National Institute for Social Security (INSS) to limit fiscal risks and improve governance and transparency; and, (ii) enhancing governance in the natural resources sector, and in this context the Government is committed to becoming a full member of EITI within the envisaged timeframe of two years.

17. Finally, the authorities and the Program Aid Partners (PAPs) have recently agreed on several economic and political governance issues during the last Annual Review concluded in May 2010. The authorities are committed to accelerate reforms in this area, which is also very important to sustain strategies to support growth and poverty reduction without increasing inequalities in the society.

\section{Conclusion}

18. Mozambique has an enormous potential for rapid economic growth, and the authorities' policy reforms are intended to unleash such potential. In this context, the authorities' desire to identify additional resources to finance an ambitious investment program is a major objective, but the success of this development drive will depend on an approach that combines prudent macroeconomic management with the identification of the right public investments. In addition, it is also clear to the authorities that securing additional 
financing for infrastructure investments is only part of the problem. This needs to be complemented with efforts to improve the business environment, allowing for greater flexibility in land and labor markets, and improving the logistics for trade. All of these ingredients are needed to unleash private sector initiative, and thereby ensure that the existing infrastructure, as well as the newly planned investments, can be fully utilized to generate economic activity and create wealth.

19. The authorities remain committed to accelerate the broader reform agenda, and mobilize the requisite financing without compromising the debt sustainability of the country. They are also aware that facing these challenges will require additional capacity and good governance. To that end, the authorities count on the support of both the Fund and other development partners to provide TA and enhance policy discussions in the implementation of their development programs. In this context, they request the completion of the sixth review under the PSI, the second review under the ESF, and the approval of the successor three-year PSI for the period 2010-2013. 
INTERNATIONAL MONETARY FUND

REPUBLIC OF MOZAMBIQUE

\title{
Sixth Review Under the Policy Support Instrument, Second Review Under the Arrangement Under the Exogenous Shocks Facility, and Request for a Three-Year Policy Support Instrument
}

\author{
Prepared by the African Department \\ (In consultation with other departments) \\ Approved by Roger Nord and Dominique Desruelle
}

May 27, 2010

\begin{abstract}
- $\quad$ Discussions were held in Maputo, March 15-31. The mission team included Messrs. Mueller (head), Staines, Rosa, Crispolti (all AFR), Mr. Vitek (SPR), Mr. Fischer (resident representative), and Ms. Bosten and Mr. Wane (resident representative office). Messrs. Sulemane (OED), Pereira da Silva (Country Director, World Bank) and Nucifora (Senior Economist, World Bank) also participated in the discussions.

- $\quad$ The mission met with Minister of Finance Chang, Minister of Planning and Development Cuereneia, Bank of Mozambique (BM) Governor Gove, other senior government officials, and representatives of the private sector, civil society, and the donor community.

- A three-day high-level conference, organized jointly by the government, the Fund, and the Bank was held in Namaacha (southern Mozambique) to discuss strategies to sustainably and equitably raise economic growth and related policy options. Fund and Bank staff were invited to present and discuss the conference's conclusions in a meeting of the Council of Ministers on March 25 in Maputo, chaired by Prime Minister Ali. The conference also informed program discussions and facilitated the identification of priority areas for structural reforms and capacity building needs.

- $\quad$ The Executive Board approved the three-year PSI on June 18, 2007 and the one-year ESF arrangement on June 30, 2009. It concluded the fifth PSI review and the first ESF review on December 6, 2009.

- In the attached Letter of Intent and Memorandum of Economic and Financial Policies (MEFP), the authorities request completion of the final PSI/ESF reviews and approval of a successor three-year PSI.
\end{abstract}




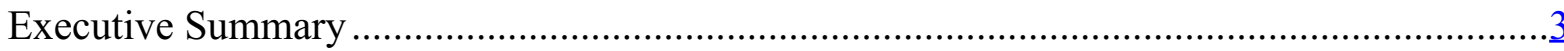

I. Exiting the Global Financial Crisis .............................................................................

II. A New PSI—Setting Policies for Sustained Growth ...........................................................

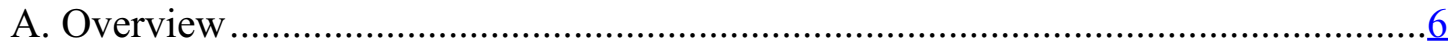

B. Achievements in Past Programs ........................................................................

C. Mozambique's Macroeconomic Challenges ……………....................................12

D. The Design of the New Program......................................................................15

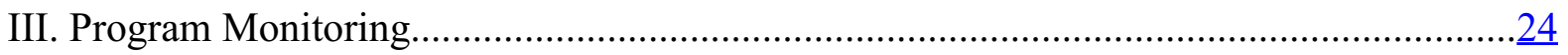

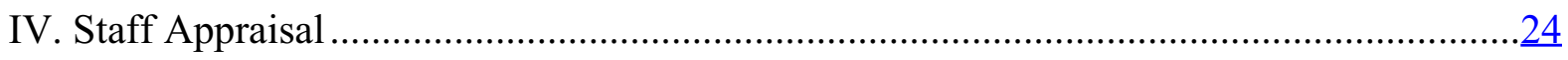

Tables

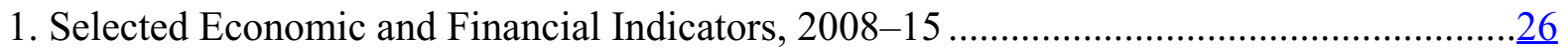

2. Government Finances, 2008-15 (MT Billions) ………...................................................27

3. Government Finances, 2008-15 (Percent of GDP) ……………………………….....

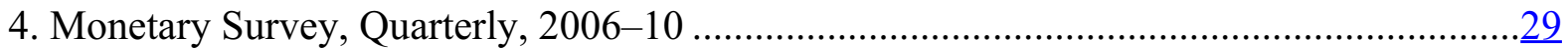

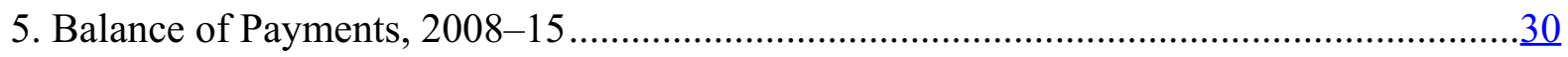

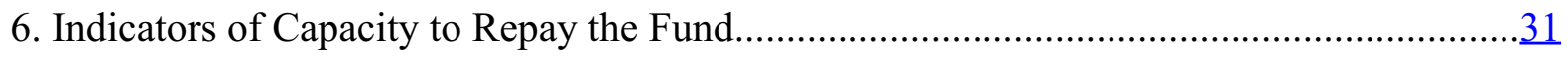

7. Financial Soundness Indicators for Banking Sector, 2001-09 ………..............................

8. Quantitative Assessment and Performance Criteria and Indicative Targets.........................

9. Structural Conditionality Under Current PSI/ESF, 2010 .................................................

Figures

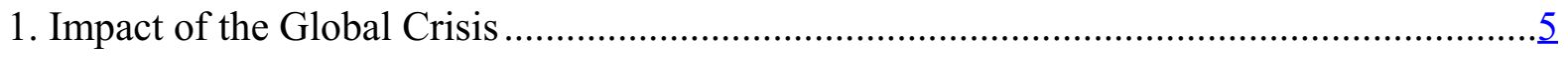

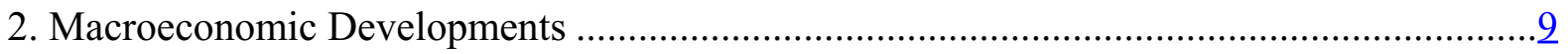

Boxes

1. Agreement on Resumption of Donor Aid .......................................................................

2. A Strong Track Record in Program Implementation Since 2004 ……………..................11

3. Namaacha Conference on Mozambique's Economic Challenges and Policy Options.........13

4. Empirical Evidence on the Determinants of Economic Growth.....................................14

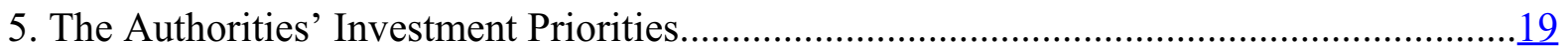

6. Enhancing Investment Planning and Debt Management ..................................................21

Appendices

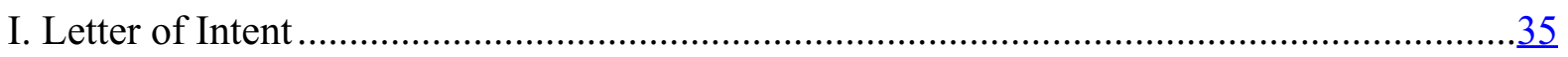

Attachment I. Memorandum of Economic and Financial Policies ........................................

Attachment II. Technical Memorandum of Understanding ...................................................51 


\section{EXECUTIVE SUMMARY}

The impact of the global crisis on Mozambique was limited. Economic activity remained buoyant in 2009, helped also by the authorities' easing of fiscal and monetary policies. The main transmission channels of the crisis were a drop in export receipts and private capital inflows, which the SDR allocation and ESF resources helped cushion. With the improved economic outlook for 2010, the authorities intend to unwind the fiscal and monetary stimuli.

The current PSI, which will expire in June, has served Mozambique well. It proved sufficiently flexible to allow the authorities to adjust their macroeconomic policies in response to two exogenous shocks: the fuel and food price surge and, more recently, the global crisis. The authorities showed commendable program ownership, with an overall strong implementation record and achievement of macroeconomic objectives. Nonetheless, difficulties remained in predicting the demand for cash in the face of rapidly expanding banking services in rural areas. This, coupled with last year's more accommodating monetary policy to help shore up the economy to the global crises, led to the nonobservance of the reserve money target for end-2009-for which the authorities request a waiver.

\section{Mozambique's economic challenges and the related policy options going forward remain daunting. The authorities aim to diversify the country's productive base and increase the role of the private sector, thereby creating employment opportunities and reducing poverty. Their focus in this regard is on expanding the transportation and electricity infrastructure networks, for which they consider tapping nonconcessional external resources. Staff analysis confirms Mozambique's relatively low capital abundance and investment rates, but suggests a cautious borrowing approach so as to preserve macroeconomic stability and debt sustainability. Other policies could be conducive to fostering private sector activity as well, including in particular efforts to create a more favorable business climate.}

\section{The successor PSI aims to support the authorities' twin objectives of accelerating economic development and maintaining macroeconomic stability. It envisages a limited and time-bound expansion of untied nonconcessional external borrowing and domestic financing to boost infrastructure investment while maintaining a prudent fiscal policy stance that would keep the primary domestic deficit broadly unchanged. Monetary policy will be sufficiently tight to keep domestic demand pressures in check while providing ample room for private sector credit expansion. The structural reform focus will be on improving the authorities' capacity for informed decision making, by promoting debt management, developing a borrowing strategy, and improving investment planning; and on continuing the ongoing reforms with respect to public financial management, tax policy and administration, the monetary policy framework, and financial sector supervision.}

Staff supports the authorities' request for waiver of the nonobservance of the endDecember 2009 assessment/performance criterion on reserve money, the completion of the final PSI/ESF program reviews, and approval of the successor PSI. 


\section{Exiting The GLOBAL Financial CRISIS}

1. Mozambique showed considerable resilience to the global crisis. Real GDP grew by $6 \frac{1}{3}$ percent in 2009 , more than expected, owing to stronger performance of the construction, energy, and financial sectors. Large declines occurred in export receipts and private capital inflows, but the impact on external reserves was mitigated by the SDR allocation and ESF resources (Figure 1).

\section{The government responded to the crisis by promptly easing}

macroeconomic policies. An accommodating monetary policy facilitated the substitution of foreign borrowing with a domestic credit expansion. Strong revenue performance has kept automatic stabilizers small, resulting in a lower-than-anticipated domestic primary deficit. Inflation has been subdued because of low commodity prices and the introduction of fuel price subsidies in May 2009, but some pick up occurred toward year-end owing to a rebound in international prices and the depreciating currency.

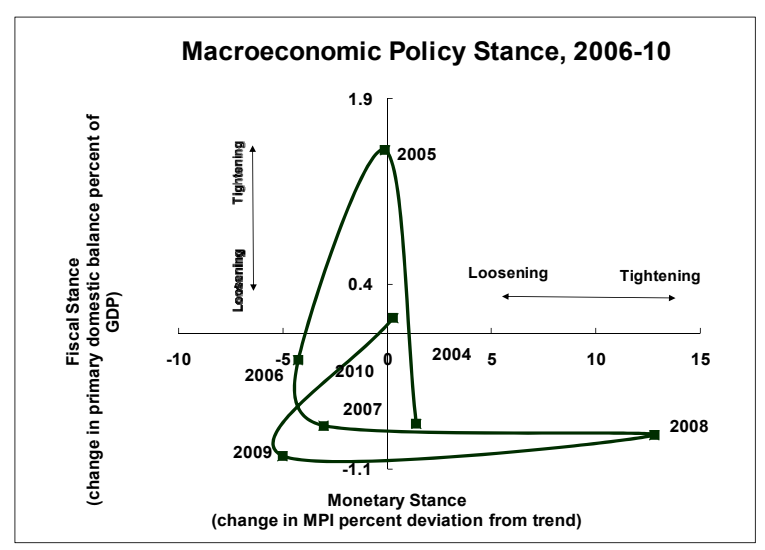

\section{The PSI provided an effective and flexible}

\section{framework to guide policies during the crisis, and program}

performance has been strong. All quantitative targets for end-December 2009 were met, except the one on reserve money. This target was missed because of the continued difficulties to predict the year-end surge in seasonal currency demand and the structural shift from an 'unbanked' to a 'banked' economy. ${ }^{1}$ In addition, the authorities deliberately eased monetary conditions more than expected to accommodate the substitution of foreign borrowing with domestic credit in a welcome effort to shore up economic activity. However, the BM is committed to restraining monetary growth in 2010. Structural reforms are on track as well; only the benchmark on the development of a financial sector contingency plan will be delayed by four months because of

\begin{tabular}{|c|c|c|}
\hline \multicolumn{3}{|c|}{ Mozambique: Quantitative Assessment and Performance Criteria and Indicative Targets } \\
\hline & \multicolumn{2}{|c|}{2009} \\
\hline & $\begin{array}{c}\text { End-Sept } \\
\text { Ind. targets } \\
\end{array}$ & $\begin{array}{c}\text { End-Dec } \\
\text { AC/PC }\end{array}$ \\
\hline \multicolumn{3}{|l|}{ Assessment/Performance Criteria for end-June/December } \\
\hline Net credit to the government (cumulative ceiling) & Met & Met \\
\hline Stock of reserve money (ceiling) & Not Met & Not Met \\
\hline Stock of net international reserves of the BM (floor, US\$ millions) & Met & Met \\
\hline $\begin{array}{l}\text { New nonconcessional external debt contracted or guaranteed by the central } \\
\text { government or the BM or State owned enterprises with maturity of one year or } \\
\text { more (ceiling, US\$ millions) }\end{array}$ & Met & Met \\
\hline Stock of short-term extemal public debt outstanding (ceiling) & Met & Met \\
\hline External payments arrears (ceiling) & Met & Met \\
\hline \multicolumn{3}{|l|}{ Indicative targets: } \\
\hline Government revenue (cumulative floor) & Met & Met \\
\hline
\end{tabular}
difficulties in securing World Bank funding for the exercise.

\footnotetext{
${ }^{1}$ More than half of Mozambique's 128 districts do not have a bank branch, although the country's four commercial banks have accelerated the expansion of their networks.
} 
Figure 1. Mozambique: Impact of the Global Crisis

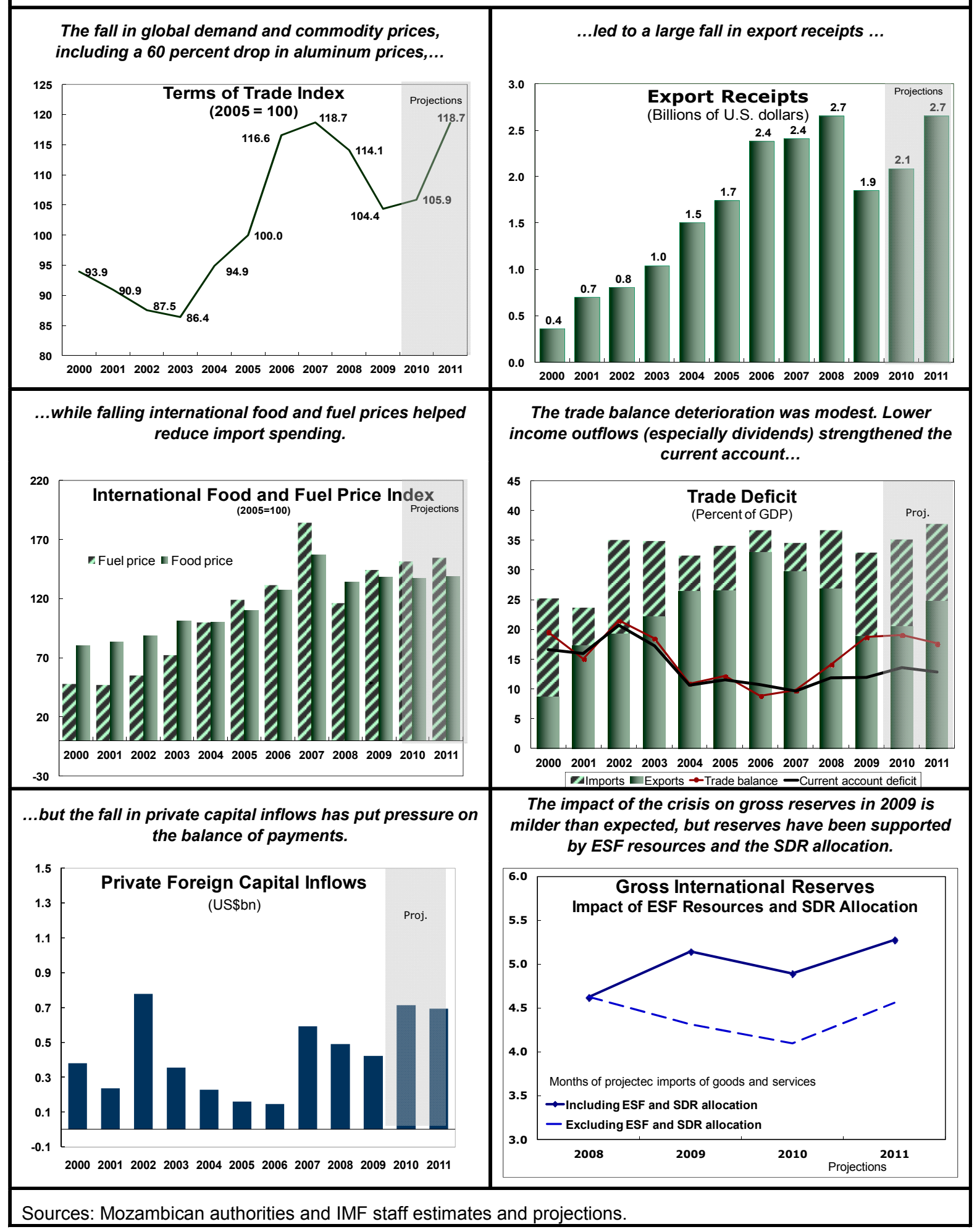


4. The economic outlook for $\mathbf{2 0 1 0}$ has improved. Growth could accelerate to $6 \frac{1}{2}$ percent in 2010 , led bynew megaprojects in the natural MEFP $97-8$ resources sector and stepped-up public investment. Inflation should remain in single digits, despite a temporary spike reflecting spillovers from the gradual removal of the fuel subsidy, which was launched in March 2010. Notwithstanding a projected sharp rise in investmentrelated imports, the recovery in export prices for Mozambique's key commodities should contain the external current account deficit and keep international reserves at a comfortable level. As outlined below, and in tandem with the improved global recovery, the authorities intend to remove in 2010 last year's fiscal and monetary stimuli.

\section{Donor support was temporarily halted over governance concerns but has}

resumed. Mozambique relies on extensive external assistance for budget financing and economic development. However, development partners expressed political and economic governance concerns that reached a nadir during the October 2009 elections and led to the temporary suspension of budget support in the first quarter of 2010 (Box 1). The authorities' recent steps to assuage these concerns through commitments to donors on governance reforms have led to a resumption of aid in April 2010, which is expected to be disbursed according to original plans. Development partners are closely monitoring implementation of the measures. The resumption of donor support, together with stepped-up foreign exchange sales by the central bank, helped remove pressure on the exchange rate and resulted in a narrowing of the temporarily large wedge between the official and the retail market rate.

\section{Box 1. Agreement on Resumption of Donor Aid}

The October 2009 elections confirmed President Guebuza in office and provided the ruling party with a very large majority. Donors were concerned about a lack of inclusiveness in the democratic process, in particular regarding newly emerging opposition parties. In March 2010, donors' political concerns were addressed through government commitments to reform the electoral law and strengthen the role of opposition parties in parliament. Economic governance concerns centered on the need to improve procurement, strengthen the anti-corruption framework, improve the management of natural resources and concessions, and enhance the business environment. The government committed to measures to address those concerns.

\section{A New PSI-Setting Policies for Sustained Growth}

\section{A. Overview}

6. Mozambique's economic performance and track record of macroeconomic stability over the last decade and a half have been impressive, making the country a prime example of a mature stabilizer. It has achieved strong economic growth, low inflation, comfortable external reserves, and a sustainable debt position thanks to the HIPC/MDRI debt relief. In addition, the country has been resilient to the recent surge in food and fuel prices and, notably, the global economic crisis. This was made possible by the 
authorities' strong commitment to prudent macroeconomic management and by a flexible program design that accommodated the authorities' policy responses to these exogenous shocks. When faced with the global crisis, Mozambique paired its PSI with a high-access ESF which, together with the subsequent SDR allocation, helped shore up the country's international reserves at a critical time.

7. As its current PSI reaches its end, the authorities and staff undertook a retrospective on Mozambique's achievements under the last two Fund-supported programs. This was intended to help draw lessons for the authorities' economic program going forward, especially since Mozambique's macroeconomic challenges remain enormous and the authorities intend to accelerate the country's economic development. Given the authorities' overall satisfaction with the PSI, they opted to request a seamless transition to a successor three-year PSI, which they hoped would help them strengthen their economic policy making and prepare them well for the challenges as a frontier emerging market economy. In this context, the retrospective served a useful role in identifying areas for improving program design. It also triggered the organization of a high-level conference, organized jointly by the authorities, the Bank, and the Fund to debate Mozambique's past achievements, identify the key economic challenges going forward, and outline the main policy options that could help the authorities in facing their macroeconomic challenges.

\section{B. Achievements in Past Programs}

\section{The authorities largely achieved their macroeconomic objectives underlying} Mozambique's fourth PRGF and the current PSI (Figure 2).

- Real GDP growth averaged almost 8 percent during 2004-09, but has trended down from the post-conflict highs following the end of the civil war in the mid-1990s.

Mozambique's growth performance has been similar to that of some fast-growing Asian economies and compares very favorably with the rest of Sub-Saharan Africa (SSA).
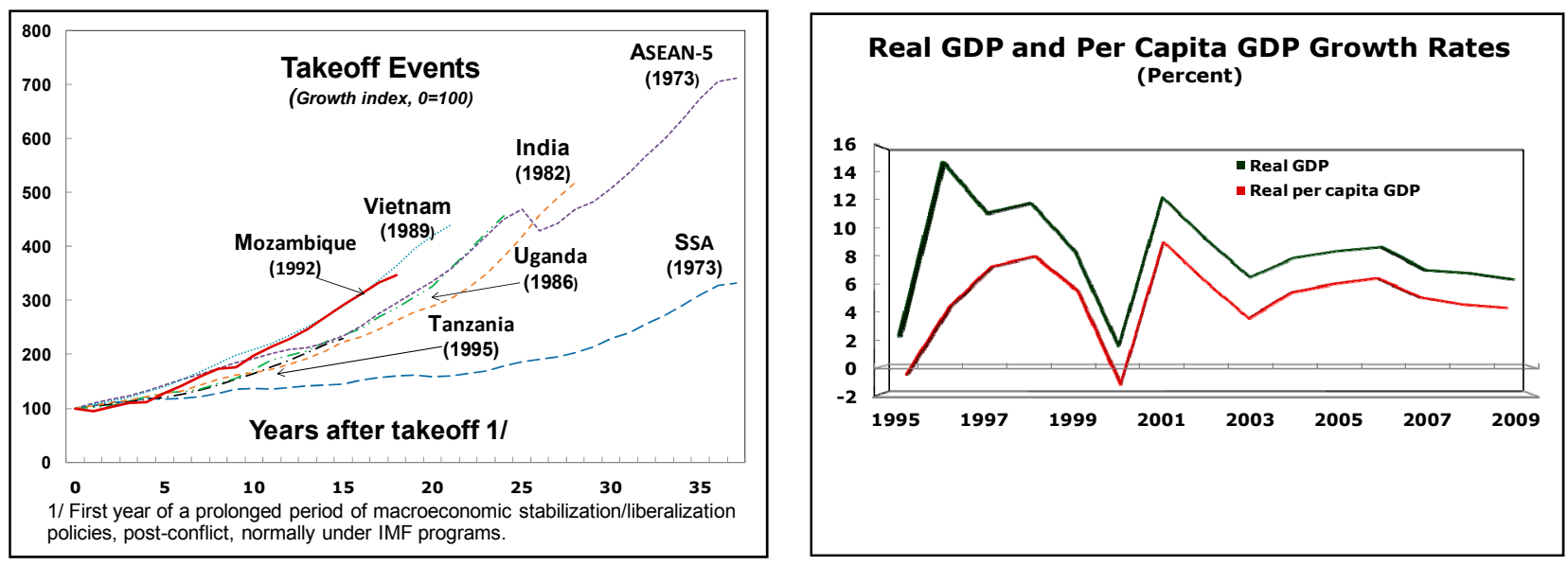
- The poverty rate fell from 69 percent in 1997 to 54 percent in 2003, the last full assessment; the results of the new household survey are expected in the next few months. Per-capita economic growth was strong over the last few years, but it remains below the $25^{\text {th }}$ percentile of the distribution for SSA countries. Some social indicators (e.g., life expectancy, literacy) have improved markedly, but achieving the MDGs remains a challenge in many areas.
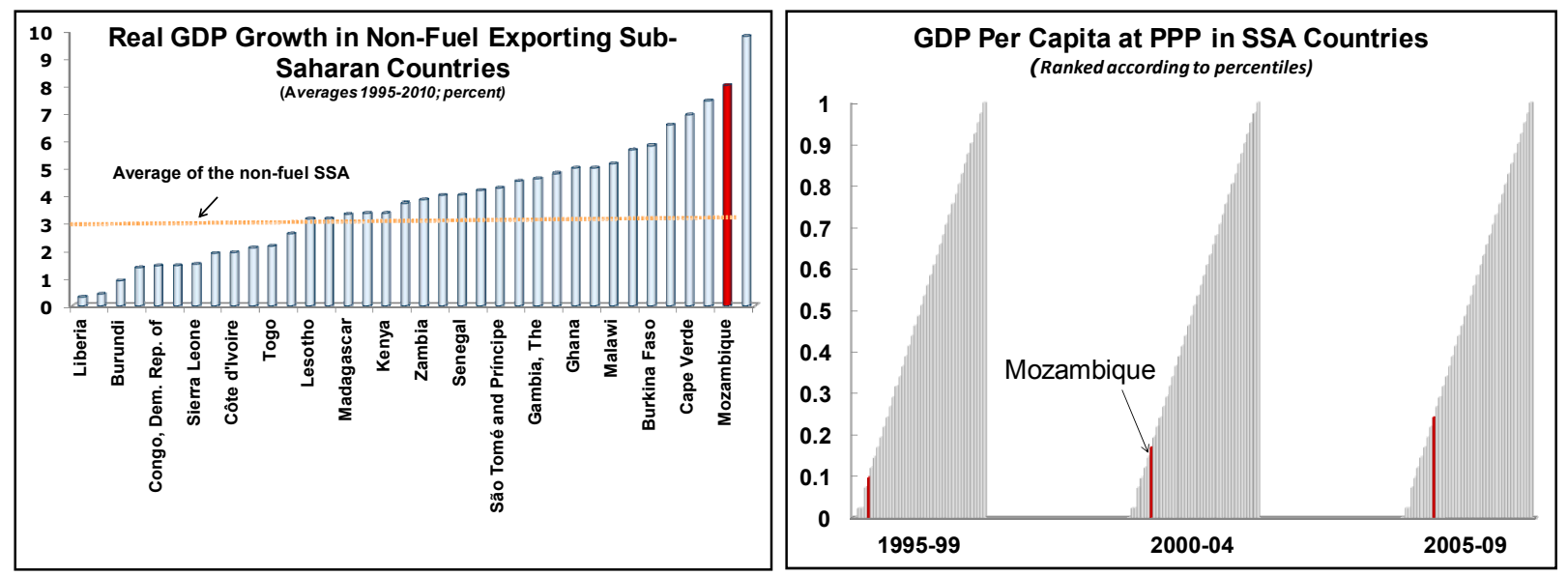

\section{Selected Millennium Development Goals, 1990-2008}

\begin{tabular}{|c|c|c|c|c|c|}
\hline & 1990 & 1995 & 2000 & 2005 & 2008 \\
\hline \multicolumn{6}{|l|}{ Goal 1: Eradicate extreme poverty and hunger } \\
\hline Employment to population ratio, $15+$, total $(\%)$ & 80 & 79 & 79 & 78 & 78 \\
\hline Employment to population ratio, ages $15-24$, total (\%) & 67 & 68 & 67 & 66 & 66 \\
\hline \multicolumn{6}{|l|}{ Goal 2: Achieve universal primary education } \\
\hline Primary completion rate, total (\% of relevant age group) & 26 & 26 & 16 & 42 & 59 \\
\hline Total enrollment, primary (\% net) & $\ldots$ & $\ldots$ & 56 & 76 & 80 \\
\hline \multicolumn{6}{|l|}{ Goal 3: Promote gender equality and empower women } \\
\hline Ratio of female to male primary enrollment (\%) & 76 & 72 & 75 & 84 & 88 \\
\hline Ratio of female to male secondary enrollment (\%) & 57 & $\ldots$ & 63 & 69 & 75 \\
\hline \multicolumn{6}{|l|}{ Goal 4: Reduce child mortality } \\
\hline Immunization, measles ( $\%$ of children ages $12-23$ months) & 59 & 71 & 71 & 77 & 77 \\
\hline Mortality rate, infant (per 1,000 live births) & 166 & 149 & 124 & 103 & 90 \\
\hline \multicolumn{6}{|l|}{ Goal 5: Improve maternal health } \\
\hline Births attended by skilled health staff (\% of total) & $\ldots$ & 44 & $\ldots$ & 48 & 55 \\
\hline Pregnant women receiving prenatal care (\%) & $\ldots$ & 71 & 76 & 85 & 89 \\
\hline \multicolumn{6}{|l|}{ Goal 6: Combat HIVIAIDS, malaria, and other diseases } \\
\hline Prevalence of HIV, total (\% of population ages 15-49) & 1.4 & 4.5 & 9.5 & 12.2 & 12.5 \\
\hline Tuberculosis case detection rate (all forms) & $\ldots$ & 59 & 47 & 47.5 & 48.8 \\
\hline \multicolumn{6}{|l|}{ Goal 7: Ensure environmental sustainability } \\
\hline Improved sanitation facilities (\% of population with access) & 20 & 22 & 27 & 31 & 31 \\
\hline Improved drinking water source (\% of population with access) & 36 & 39 & 41 & 42 & 42 \\
\hline
\end{tabular}

Source: World Development Indicators 
Figure 2. Mozambique: Macroeconomic Developments

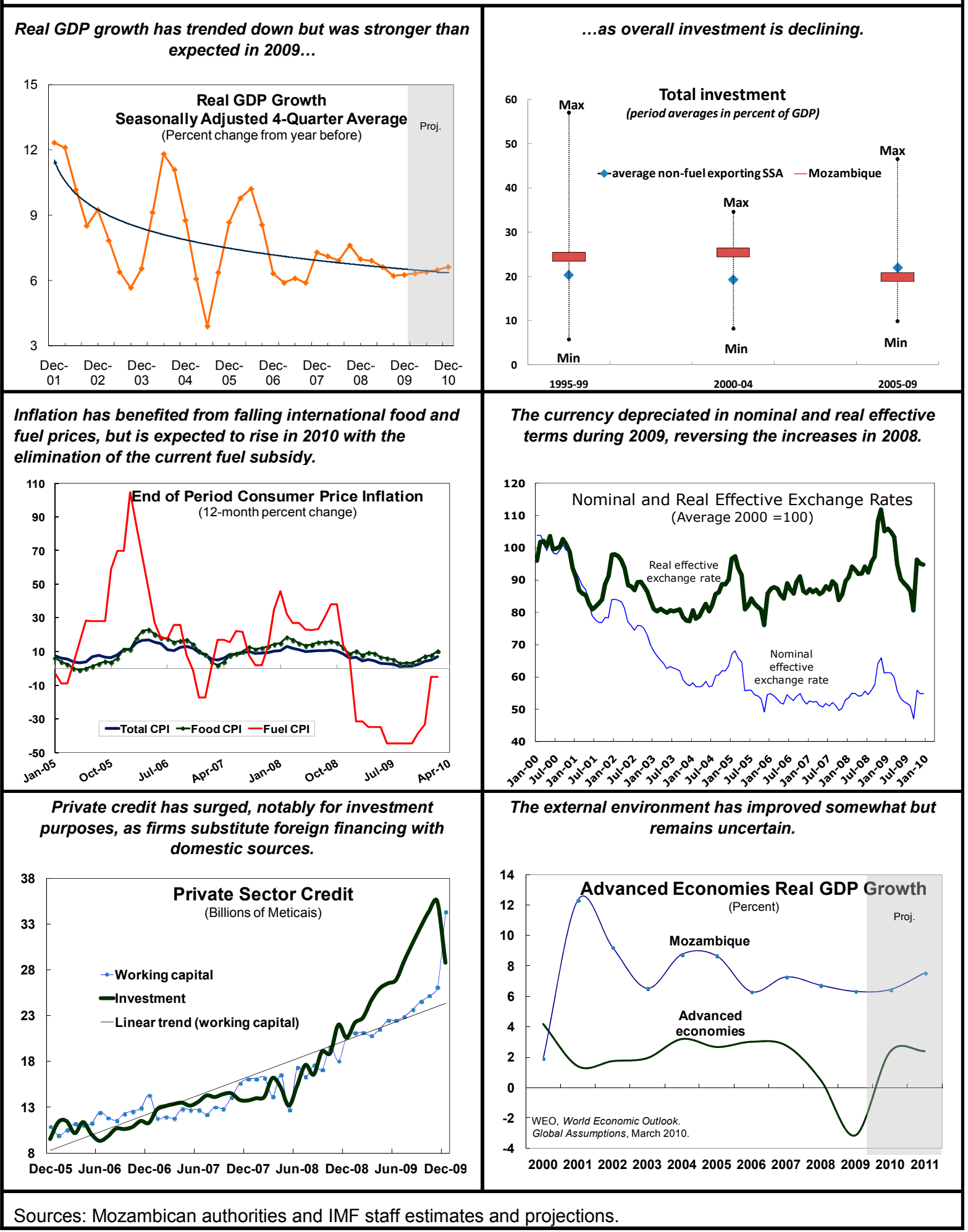


- Inflation has trended down and has generally remained in single digits, except in those episodes of surging international food and fuel prices.

- The current account deficit (after grants) strengthened from around 18 percent of GDP during 2000-03 to about 10 percent of GDP in 2004-09, mainly because of megaproject exports, including in particular from the aluminum smelter Mozal.

- Capital inflows have been high but volatile and averaged 20 percent of GDP during 2004-09. Aid exceeded 13 percent of GDP during the last four years, making donor support a crucial contributor to Mozambique's economic success.

- As a result, Mozambique's international reserves generally surpassed four months of imports and were further boosted in 2009 by access to the ESF and the SDR allocation.

- Mozambique has a low public debt burden and, following MDRI/HIPC debt relief, a low risk of external debt distress.

9. Program performance was generally very strong (Box 2$)$. The authorities showed commendable ownership in pursuing sound economic policies that were underpinned by a focus on structural reforms aimed at enhancing economic policy-making. A protracted period of political stability was also important in securing these results.

\section{The authorities noted that they felt greater ownership under the PSI than under} prior programs. They appreciated the self-discipline imposed by a Fund program, while noting that even though conditionality had declined over time, their commitment to the underlying reforms remained strong - because they wanted to implement those reforms. They also valued the Fund's enhanced flexibility in response to the various exogenous shocks. The authorities saw the program relationship as instrumental in helping them build their capacity in economic policy making. It was mostly felt that a successor PSI would be particularly useful in the current environment when Mozambique is expected to be confronted with more complicated policy issues, such as accessing market financing. In this context, a close engagement with the Fund would provide expertise and act as a counterbalance against overly ambitious and optimistic plans. 


\section{Box 2. A Strong Track Record in Program Implementation Since 2004}

\section{A prudent macroeconomic policy mix aimed to preserve macroeconomic stability:}

- Fiscal policy sought to avoid domestic financing to make room for private sector credit. Fiscal deficits were almost exclusively financed on concessional terms, thanks to strong donor engagement. Nonconcessional borrowing was limited to near zero under the Fundsupported programs.

- Monetary policy successfully managed to contain inflation, relying on reserve money as the operational target.

\section{Program design was flexible:}

- Program targets were loosened to accommodate the authorities' response to the food and fuel price surge and, more recently, to the global crisis.

- The performance criterion (PC) on the domestic primary deficit was relaxed at the fourth PRGF review to use the fiscal space created by the MDRI for additional priority spending. It was subsequently replaced by a PC on net credit to the government, which allowed for unexpected aid to be spent.

\section{Program implementation was strong, reflecting strong ownership:}

- The reviews were completed on time.

- Fiscal policy and NIR targets were generally met. But the reserve money target was regularly overshot because of difficulties in predicting demand for cash in a country transitioning to a banked economy.

- Observance of structural conditionality improved over time. Some two-thirds of structural measures under the PRGF were implemented on time, compared to four-fifths under the PSI. Compliance was the lowest in reforms outside the Fund's area of expertise, reflecting a lack of follow-up by development partners, although compliance improved markedly under the PSI.

- Structural conditionality was streamlined, partly reflecting conditionality reform at the Fund and partly the authorities' growing program ownership. Prior actions were discontinued after the fourth PRGF review in mid-2006. Structural performance/assessment criteria were halved over time and discontinued altogether after the third PSI review in late 2008.

- Structural conditionality focused on measures within the Fund's core area of expertise and was supported by extensive technical assistance (TA) on public financial management (PFM), tax policy and administration, and monetary and financial sector policies. Its selection benefited from close cooperation between the area and functional departments, and the TA coordinator operating from the local Fund office. 


\section{Mozambique's Macroeconomic Challenges}

\section{After enjoying an impressive recovery in the decade and a half following the end} of the civil war, economic expansion has gradually been decelerating and become dependent on megaprojects in the natural resources sector. Notwithstanding the contribution of megaprojects to growth, ${ }^{2}$ their spillovers to the rest of the economy have been limited, owing to shallow vertical and horizontal integration, high physical capital intensity, profit repatriation patterns, and low tax revenue contributions. As a result, sectoral contributions to growth have been uneven, with a still subdued participation of the private sector outside the megaprojects. Private investment has not taken off as much as in most peer countries, little employment has been generated, and development indicators, while improving, are still low. In addition, the traditional export sector has lagged behind, which has led to a concentration of the export base and a heightened external vulnerability. By end-2008, exports of aluminum, electricity, and natural gas accounted for about 60 percent of total exports.
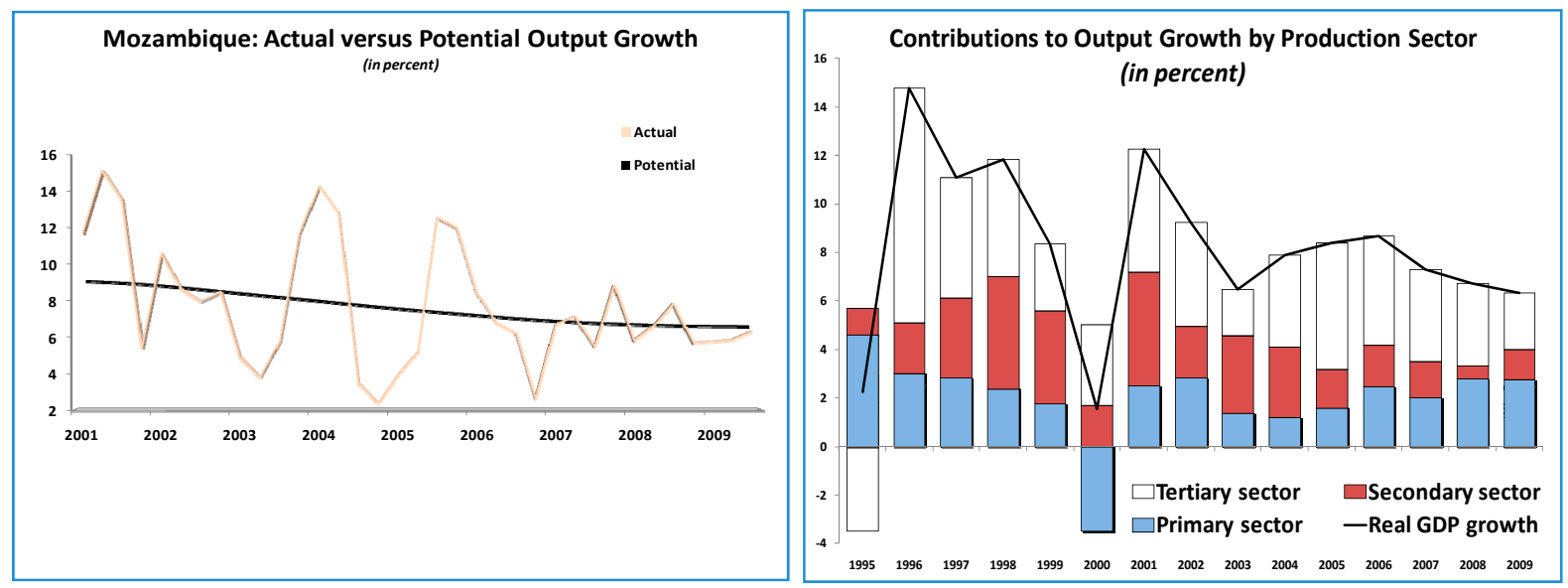

\section{A sustained improvement in living standards would require policies to diversify}

\section{the country's productive and export base and increase the role of the private sector.} Those policy challenges were discussed during a three-day high-level conference in the midst of the program negotiation mission. The conference, which helped shape the program discussions, was held in Namaacha (southern Mozambique) and organized jointly by the authorities, the Bank, and the Fund. Bank and Fund staff were subsequently invited to present the conference's conclusions to a special meeting of the Council of Ministers in the capital Maputo (Box 3).

\footnotetext{
${ }^{2}$ Megaprojects dominate the economic activity in the secondary sector, and waves of new megaprojects have triggered a rise of the sector's contribution to GDP growth. During the post-conflict economic expansion, the secondary sector grew by 13 percent on average, while the primary and the tertiary sectors grew by $7 \frac{1}{2}$ percent respectively. As a result, the production share of the secondary sector rose from 12 to 23 percent, while that of the primary sector fell from 29 to 26 percent, and that of the tertiary sector from 59 to 52 percent.
} 


\section{Box 3. Namaacha Conference on Mozambique's Economic Challenges and Policy Options}

The three-day conference was attended by 140 participants, including current and former members of government, senior managers of line ministries, and representatives of the private sector, academia, civil society, and development partners. It received wide media coverage. The format emphasized a collaborative approach, in which Fund and Bank staff introduced each topic with an analytical presentation, which was followed by the authorities' analysis and a subsequent panel and open-floor discussion of the issue at stake.

There was broad recognition of Mozambique's impressive economic growth and macroeconomic stability since the end of the civil war - an achievement that needed to be preserved. At the same time, growth had been trending down, and a large part of the population still lives below the poverty line. There was agreement that in order to sustain higher and more inclusive economic growth going forward, the government would need to encourage economic activity driven by the private sector. Various strategies were discussed, including boosting public investment, creating a more enabling business environment, developing key sectors in the economy, enhancing regional integration with neighboring countries, and better tapping Mozambique's comparative advantages.

The last day of the seminar was devoted to the need for informed borrowing decisions should Mozambique decide to tap financing at commercial terms. Bank and Fund experts explained the advantages and pitfalls of various financing instruments, including bonds, (syndicated) loans, financing from bilateral development banks, and Public-Private Partnerships (PPP). They also urged the authorities to build institutional capacity for improved debt management and to develop a multi-year strategy to guide them in their external and domestic borrowing.

\section{Raising the country's growth and export potential would thus hinge on creating} an environment conducive to private sector activity. The authorities' thinking is centered on boosting public investment, with a view to expanding the transportation and electricity networks in the vast country to allow private sector activity to emerge. Such investment could partially be financed by nonconcessional external resources if efforts to raise additional concessional funds and strengthen revenue collections proved insufficient.

\section{Staff analysis supports the potential merits of boosting investment but urges a} cautious approach. Mozambique's capital abundance and investment rates, especially private investment, are very low indeed (Box 4). However, staffs' simulations show that a permanent increase in public investment over the next two decades financed exclusively at market terms, would noticeably worsen Mozambique's debt indicators and impact macroeconomic stability. This suggests that the

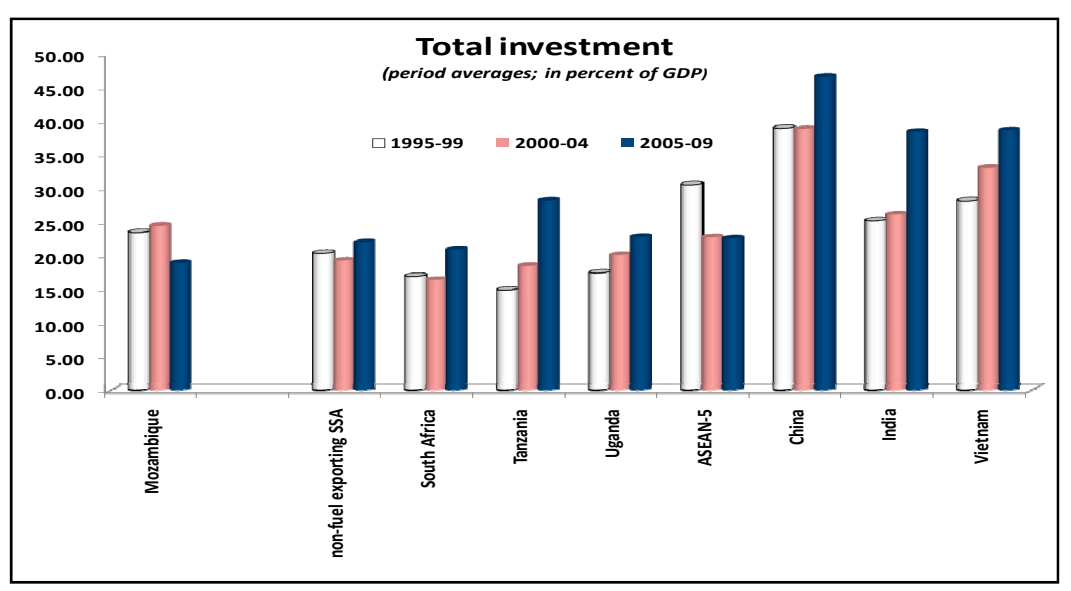
authorities should adopt a more limited and time-bound scaling up of their investment. Emphasis should also be placed on the quality of projects so as to ensure an adequate growth dividend and the ability to repay the additional borrowing. This in turn hinges on the development of a consistent cross-sectoral investment strategy that would prioritize projects 
based on feasibility studies and cost-benefit analyses and their potential to promote private investment. This crowding in of private investment appears to be Mozambique's most promising avenue to create jobs and reduce poverty.

\section{Box 4. Empirical Evidence on the Determinants of Economic Growth}

Staff conducted an empirical analysis of the determinants of growth in living standards in Mozambique, to assess how investment in infrastructure contributes to it. The results suggest that a 1 percent increase in the rate of public investment could raise output growth by up to 0.5 percent on impact, whereas a 1 percent increase in the rate of private investment could raise output growth by up to 1.3 percent on impact.

These results indicate that public investment in infrastructure, where Mozambique still ranks in the bottom percentile and below SSA averages, could yield higher growth, provided the business environment and economic governance improve as well. But the persistence of the expansionary effect of public investment will depend on the degree to which it promotes future private investment. To achieve this, public investment should be well targeted to raise the benefits and reduce the costs of private investment.
Estimation results for panel error correction model of output per capita growth

\begin{tabular}{lcc}
\hline \hline & Advanced Economies Included & Advanced Economies Excluded \\
\hline Short run dynamics: Coefficients & & \\
Lagged output per capita & 0.035 & 0.034 \\
Foreign output per capita & $0.042^{* * *}$ & $0.042^{* * *}$ \\
Real interest rate & $-0.201^{* *}$ & $-0.225^{* *}$ \\
Real effective exchange rate & -0.005 & -0.006 \\
Long run disequilibrium & $-0.280^{* * *}$ & $-0.274^{* * *}$ \\
\hline Long run trend: Parameters & & \\
Productivity growth rate & $0.018^{* * *}$ & $0.016^{* * *}$ \\
Private physical capital intensity & $0.160^{* * *}$ & $0.164^{* * *}$ \\
Public physical capital intensity & $0.060^{*}$ & $0.059^{*}$ \\
Human capital intensity & 0.030 & 0.024 \\
\hline Diagnostics: & & \\
Observations & 2155 & 1967 \\
R Squared & 0.206 & 0.197 \\
\hline \hline
\end{tabular}

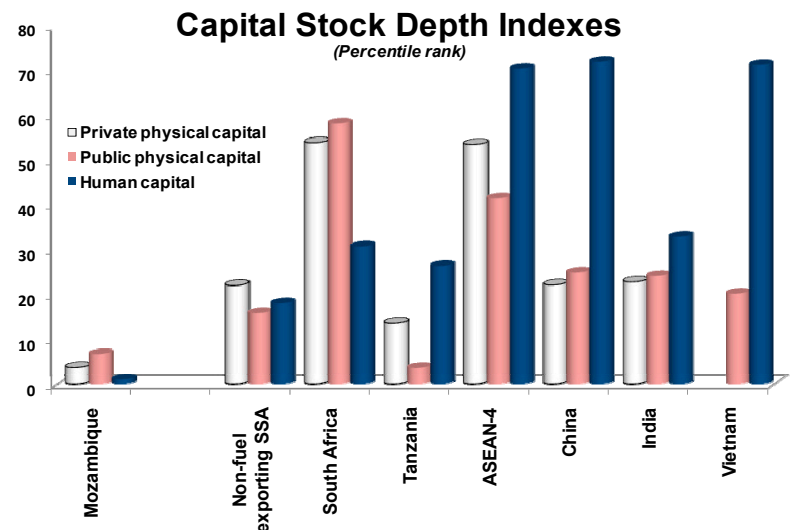

15. Various analyses, including by the Bank, also suggest a need to better tap Mozambique's comparative advantages. ${ }^{3}$ Those include an abundance of arable land and the country's geographical location, which suggest enormous possibilities to enhance regional trade (especially with its landlocked neighbors) and develop key industries, such as agro-industries, textile, and tourism. Such sectoral growth strategies would in turn also benefit from the authorities' plans to develop infrastructure. But all efforts to develop the country would be
Mozambique's Ranking in Doing Business, 2010

\begin{tabular}{lc}
\hline Indicator & Rank \\
\hline Ease of Doing Business & 135 \\
Starting a business & 96 \\
Dealing with construction permits & 159 \\
Registering property & 151 \\
Getting credit & 127 \\
Protecting investors & 41 \\
Paying taxes & 97 \\
Trading across borders & 136 \\
Enforcing contracts & 129 \\
Closing a business & 136 \\
\hline
\end{tabular}

Source: The World Bank Group, Doing Business Indicators, 2010.

${ }^{3}$ See Mozambique, Country Economic Memorandum, forthcoming. 
impaired if the authorities failed to step up their efforts to improve the business climate, since Mozambique ranks well behind its SSA peers in survey-based indicators.

\section{The Design of the New Program}

MEFP $\mid 5-10$

\section{Striking the balance between economic development and macroeconomic stability}

16. The successor PSI intends to support the authorities' development objectives while safeguarding macroeconomic stability. The authorities aim to create the conditions for sustainably raising economic growth and reducing poverty. They are adamant that meeting their development needs now requires significantly stepping up public investment in transport and electricity infrastructure, which would necessitate broadening the financing options to also include nonconcessional borrowing and expand reliance on concessions and PPPs. They see such infrastructure investment as a key prerequisite to boost regional trade and private sector activity throughout the country, which they intend to complement with enhanced efforts to improve the business climate. These developmental objectives notwithstanding, the authorities reiterate that safeguarding macroeconomic stability continues to be their overriding priority.

17. A time-bound increase in public investment could be consistent with maintaining macroeconomic stability, as well as debt sustainability, but is not without risks. It would require a changed fiscal policy stance over the next few years that would aim at creating the fiscal space to implement the authorities' investment priorities. This would mainly be achieved through a sustained revenue effort and an increasing recourse to nonconcessional and domestic borrowing. Staff and the authorities agreed that the virtually zero limit on nonconcessional external borrowing under Mozambique's last two Fund-supported programs was inconsistent with the country's vast developmental needs and should be relaxed, allowing Mozambique to reap the benefits from its strong track record of prudent macroeconomic policies and comfortable debt indicators. In addition, the sharp increase in financial intermediation provides some room to increase domestic financing of the budget without the risk of crowding out private sector credit. However, an excessive and permanent - versus a contained and time-bound - expansion of public investment could undermine debt sustainability, create undesirable domestic demand pressures, and strain institutional capacity.

\section{The program embeds the expansion of the authorities' public investment} program in transportation and energy infrastructure over the next three years in a prudent macroeconomic policy mix. The authorities committed to a policy stance that would keep the domestic primary balance broadly stable during the program period and tighten monetary policy to ward off inflationary pressures while supporting a continued financial deepening. 
19. The envisaged policy stance is not expected to increase domestic demand pressures nor burden the current account and reserve levels. The high import component and external financing of the planned investment and underutilized labor markets should contain inflationary effects and prevent a crowding out of private investment. While the higher imports could potentially worsen the external current account deficit, they are expected to be broadly offset by a recovery in export prices and a larger and more diversified export base arising from the coming online of new megaprojects in the natural resources sector. ${ }^{4}$ This should also help

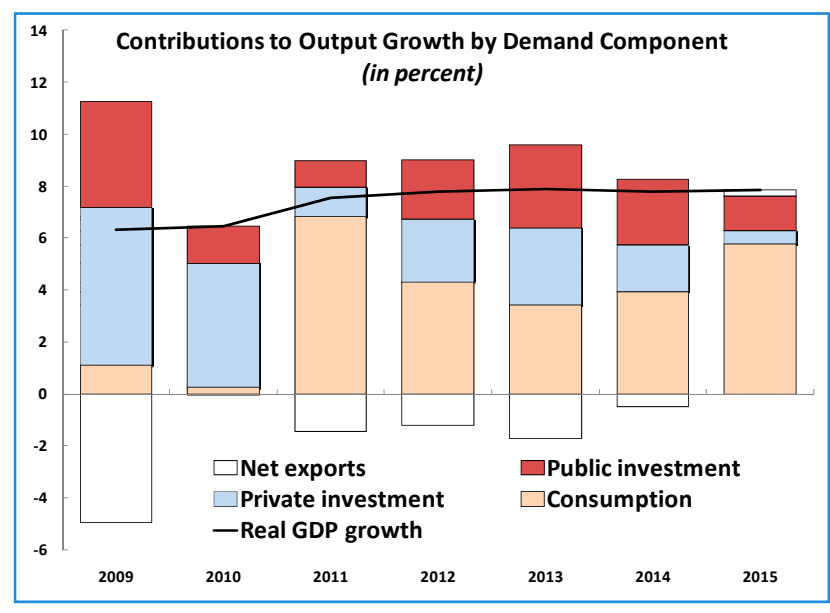
broadly stabilize Mozambique's reserve cover over the medium term and prepare the country well for the challenge to service the debt from the envisaged new external borrowing.

Selected Indicators, 2008-15

\begin{tabular}{|c|c|c|c|c|c|c|c|c|}
\hline & 2008 & 2009 & 2010 & 2011 & 2012 & 2013 & 2014 & 2015 \\
\hline & \multicolumn{2}{|c|}{ Actual } & \multicolumn{6}{|c|}{ Projections } \\
\hline Real GDP, percent change & 6.7 & 6.3 & 6.5 & 7.5 & 7.6 & 7.9 & 7.8 & 7.8 \\
\hline Inflation, eop, percent change & 6.2 & 4.2 & 8.0 & 5.6 & 5.6 & 5.6 & 5.6 & 5.6 \\
\hline Inflation, average, percent change & 10.3 & 3.3 & 9.3 & 5.6 & 5.6 & 5.6 & 5.6 & 5.6 \\
\hline Current account deficit (after grants), percent of GDP & -11.9 & -11.9 & -13.6 & -12.8 & -13.5 & -13.4 & -13.0 & -12.8 \\
\hline Gross external reserves, months of projected imports & 4.6 & 5.1 & 4.9 & 5.3 & 5.6 & 5.7 & 5.5 & 5.3 \\
\hline Primary domestic fiscal deficit, percent of GDP & -3.2 & -4.4 & -4.2 & -4.6 & -4.4 & -4.0 & -3.8 & -3.7 \\
\hline Overall fiscal deficit (after grants), percent of GDP & -2.3 & -5.6 & -4.7 & -7.2 & -6.8 & -6.1 & -5.3 & -5.1 \\
\hline Fiscal external financing, percent of GDP & 4.0 & 5.1 & 4.3 & 6.3 & 5.9 & 5.4 & 4.5 & 4.3 \\
\hline Net credit to government, percent of GDP & -1.7 & 0.3 & 0.3 & 0.9 & 0.9 & 0.7 & 0.8 & 0.8 \\
\hline Private sector credit, percent change & 45.9 & 58.6 & 19.1 & 14.0 & 14.9 & 15.8 & 15.7 & 15.8 \\
\hline Private sector credit, percent of GDP & 18.8 & 27.1 & 27.8 & 27.9 & 28.1 & 28.6 & 29.1 & 29.6 \\
\hline Reserve money, percent change & 7.8 & 27.3 & 19.5 & 14.7 & 15.0 & 15.1 & 14.9 & 15.0 \\
\hline
\end{tabular}

20. Should contrary to expectations the investment program overextend the capacity of the economy, the authorities stand ready to adjust macroeconomic policies accordingly. They will pay special attention to the emergence of inflationary pressures and signs of a crowding out of the private sector. In this case, they would tighten monetary policy and revisit their budgetary spending plans so as to contain the government's financing needs.

\section{The structural reform focus under the successor PSI}

should help shore up the authorities' policy objectives. The reforms aim to strengthen the authorities' economic management capacity to

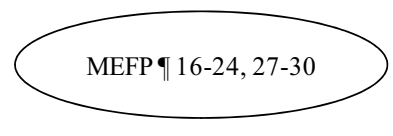
help them cope better with the increasingly sophisticated policy environment emanating from, in particular, the possible access to market borrowing and related challenges to the coordination of fiscal and monetary policies. As such, the initial focus of structural conditionality will be on enabling the authorities to make informed decisions with respect to

\footnotetext{
${ }^{4}$ The Rio Doce coal mine is expected to launch production and exports in 2011 , and investment is ongoing to allow an increase in Mozambique's natural gas and titanium exports by half during 2011-13.
} 
the financing of their investment program, by strengthening debt management, supporting the development of a coherent borrowing strategy, and creating a sound framework for PPPs and concessions. In tandem with the authorities making progress in those areas, it is expected that the focus of structural conditionality will shift back over time to the ongoing reforms to strengthen public financial management, modernize tax policy and administration, support the BM's move toward an inflation targeting framework, and foster financial sector soundness and deepening. Extensive Fund TA is being provided in those areas, which will facilitate the selection of priority measures for future conditionality during the course of the three-year program. Any reform measures outside of the Fund's core areas of expertise, such as on improving the business environment, will be taken up by other development partners.

Mozambique: Proposed Structural Benchmarks under the Successor PSI, 2010

\begin{tabular}{|c|c|c|c|}
\hline Structural Benchmarks & $\begin{array}{l}\text { Reference } \\
\text { Paragraph in the } \\
\text { MEFP }\end{array}$ & Macroeconomic Relevance & $\begin{array}{l}\text { Expected Date of } \\
\text { Implementation }\end{array}$ \\
\hline $\begin{array}{l}\text { Any new contracting of nonconcessional external borrowing } \\
\text { or guarantees by the Central Government and selected state- } \\
\text { owned entities (SOEs) subject to the related continuous } \\
\text { quantitative AC will be for transportation and electricity } \\
\text { infrastructure investment. }\end{array}$ & 14,15 & $\begin{array}{l}\text { Channel more costly financial resources to sectors that have } \\
\text { the potential to raise the country's growth potential, thereby } \\
\text { supporting debt sustainability. }\end{array}$ & Continuous \\
\hline $\begin{array}{l}\text { Adoption by Council of Ministers of PPP, Concessions and } \\
\text { Megaprojects Law. }\end{array}$ & 22 & $\begin{array}{l}\text { Reinforce investment planning, limit fiscal and quasi-fiscal } \\
\text { risks, and maximize economic benefits. }\end{array}$ & End-September 2010 \\
\hline $\begin{array}{l}\text { Finalization of a comprehensive debt strategy that will } \\
\text { assess the risk profile and the fiscal and macroeconomic } \\
\text { implications of new borrowing. }\end{array}$ & 16 & $\begin{array}{l}\text { Safeguard macroeconomic stability and debt sustainability } \\
\text { through informed borrowing decisions. Support development } \\
\text { of domestic financial markets. }\end{array}$ & End-November 2010 \\
\hline Completion of first Government Debt Sustainability Analysis. & 17 & $\begin{array}{l}\text { Enhance the authorities' capacity to make informed decisions } \\
\text { about borrowing options and the evaluation of risks to } \\
\text { macroeconomic stability and debt sustainability. }\end{array}$ & End-September 2010 \\
\hline
\end{tabular}

\section{Creating fiscal space to step up public investment}

\section{The adjusted policy mix aiming to support Mozambique's development objectives} hinges on the creation of new fiscal space. During the past two Fund-supported programs, Mozambique successfully created fiscal space primarily through a sustained revenue effort and expanded donor support, which underpinned an expansion of both current and capital spending. Going forward, the program envisages the creation of additional fiscal space through a further increase in revenue collections ( $1 \frac{1}{2}$ percent of GDP), a moderate expansion of domestic financing ( $1 / 2$ percent of GDP), and nonconcessional external borrowing ( $2 \frac{1}{2}$ percent of GDP); gross aid flows are projected to decline somewhat during the program period. The revenue effort reflects the ongoing improvements in tax administration and tax policy under the program, which are being supported by Fund TA. ${ }^{5}$ This additional fiscal space will largely be channeled to support the public investment program (Box 5).

\footnotetext{
${ }^{5}$ A recent assessment of the tax system concluded that Mozambique's potential tax ratio could exceed 21 percent of GDP in the long run. See International Monetary Fund, 2009, "Evaluation of Reforms in Tax Policy and Administration in Mozambique and Related TA - 1994-2007”.
} 
Mozambique: Creation of Fiscal Space

\begin{tabular}{lrr}
\hline & 2005-09 & $2010-13$ \\
\hline Source of fiscal space & (Cumulative change in percent of GDP) \\
Domestic contribution & 6.2 & 2.9 \\
Revenues & 4.2 & 1.4 \\
Domestic interest payments & 4.7 & 1.2 \\
Domestic financing (net) & 0.4 & -0.1 \\
Privatization receipts & 0.9 & 0.4 \\
External contribution & -1.8 & -0.1 \\
Grants & 2.1 & 1.5 \\
Project & 1.8 & 0.4 \\
Nonproject & 1.3 & 0.9 \\
Concessional external financing & 0.5 & -0.4 \\
Nonconcessional external financing 1/ & 0.3 & -1.1 \\
Use of fiscal space & 0.0 & 2.2 \\
Total current expenditures (excl. unallocated) & 6.2 & 2.9 \\
Of which: wages & 3.8 & 0.5 \\
Other current spending & 1.8 & -0.1 \\
Unallocated revenues/expenditures 2/ & 2.0 & 0.6 \\
Development expenditures & -0.9 & 0.0 \\
Memorandum items: & 3.3 & 2.5 \\
Source of fiscal space (including Portuguese loan) & & \\
Use of fiscal space (including Portuguese loan) & $\ldots$ & $\ldots$ \\
\hline
\end{tabular}

Source: IMF staff calculations

1/ Excludes the Portuguese credit line that will be implemented by the Road Fund.

2/ Corresponds to the reduction of unclassified or unrecorded transactions, which was made possible by the public financial management system reforms.

\section{The stepped-up investment program will not compromise Mozambique's}

\section{traditionally prudent fiscal policy stance.}

While the overall fiscal deficit (after grants) will temporarily rise by about 2 percentage points, to a peak of about 7 percent of GDP by 2011 , the domestic primary deficit will remain broadly stable at its current level of about 4 to $4 \frac{1}{2}$ percent of GDP during the program period. This represents a tightening relative to 2009, as the authorities intend to unwind the fiscal stimulus from the crisis year and contain current expenditure. In addition, consistent with their program commitments, they initiated the removal of

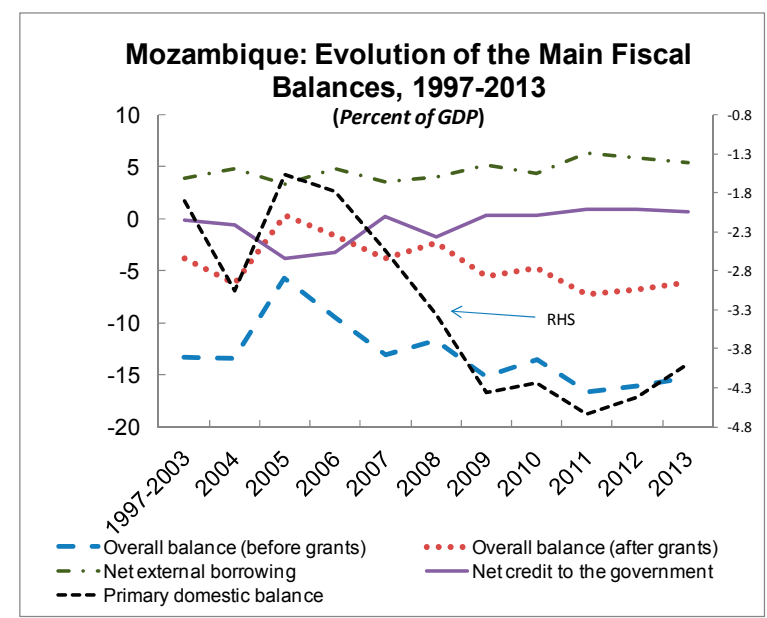
the fuel subsidy, which accounted for spending of above 1 percent of GDP in 2009; as a result, since end-March, average retail fuel prices have been adjusted in two steps by a cumulative 30 percent.

\section{The authorities remain committed to expanding priority social}

expenditure. This is consistent with their poverty reduction strategy (PARPA), MEFP $₫ 18$ which is expected to be updated this year. The PARPA-defined priority expenditure averaged three-fifths of total spending during 2007-09, which the authorities intend to broadly maintain going forward. An indicative floor to this effect was introduced to the program. 


\section{Box 5. The Authorities' Investment Priorities}

The authorities plan to step up their public investment program over the medium term. They expect that several of the key projects will enjoy financing and/or co-financing from development partners and be implemented through either the budget or selected state-owned enterprises (SOEs), such as the Road Fund, the water utility (FIPAG), and the electricity company (EDM). ${ }^{1 /}$ Some projects are planned to be developed under a concession or a PPP, for which the legal framework will be strengthened under the program (a structural benchmark).

The increase in the public investment program aims to remove bottlenecks in transportation and energy infrastructure. The authorities are currently

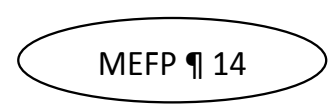
assessing the prioritization and sequencing of infrastructure investment projects and expect to complete this process by the time of the first program review. Current indications point toward a front-loaded expansion of the investment program of 5 $1 / 2$ percent of GDP over the next two years, which would abate somewhat thereafter. The MEFP provides an overview of some key projects that at present enjoy the authorities' priorities.

Mozambique: Total Public Investment Program, 2009-15

\begin{tabular}{lrrrrrrr}
\hline & 2009 & 2010 & 2011 & 2012 & 2013 & 2014 & 2015 \\
\hline & & \multicolumn{7}{c}{ (Percent of GDP) } \\
& 13.1 & 15.4 & 18.6 & 18.4 & 18.0 & 17.4 & 17.3 \\
Total & 13.1 & 13.9 & 17.1 & 17.0 & 16.8 & 16.3 & 16.5 \\
$\quad$ On budget & 4.5 & 6.1 & 6.5 & 6.8 & 6.9 & 7.0 & 7.3 \\
$\quad$ Domestically financed & 8.6 & 7.8 & 7.8 & 7.8 & 7.8 & 7.8 & 7.8 \\
$\quad$ Donor financed, concessional & 0.0 & 0.0 & 2.8 & 2.5 & 2.2 & 1.6 & 1.4 \\
$\quad$ Non-concessional & 0.0 & 1.4 & 1.6 & 1.4 & 1.2 & 1.1 & 0.8 \\
$\quad$ Credit line from Portugal 1/ & 0.0 & 0.8 & 0.9 & 0.8 & 0.7 & 0.6 & 0.5 \\
$\quad$ Concessional & 0.0 & 0.6 & 0.7 & 0.6 & 0.5 & 0.5 & 0.4 \\
$\quad$ Nonconcessional & & & & & & & \\
$\quad$ Memorandum items: & & & & & & & \\
$\quad$ Total concessional and domestic & 13.1 & 14.7 & 15.2 & 15.3 & 15.3 & 15.4 & 15.5 \\
$\quad$ Total nonconcessional & 0.0 & 0.6 & 3.5 & 3.1 & 2.7 & 2.0 & 1.8 \\
\hline
\end{tabular}

Source: IMF staff calculations.

1/ Portuguese credit line that will be implemented by the Road Fund.

The authorities intend to maximize the return on investment. They plan to focus on projects that they consider could play a pivotal role in improving MEFP q 14-18 transportation links between economic centers and to border posts with Mozambique's neighbors, including landlocked Zimbabwe and Malawi. This is expected to stimulate private sector activity and economic growth. They are assessing the scope of recovering the investment and borrowing costs for some projects through concessions, user fees, and tolls, such as for key road corridors, bridges, and the power transmission line from the Cahorra-Bassa dam to the capital city Maputo; several existing roads and bridges are already toll-based. All such planned projects will be based on feasibility studies, including in some cases also from participating development partners. A continuous structural benchmark will ensure that all projects financed by nonconcessional resources subject to the related assessment criterion under the PSI will be in the transportation and energy sectors.

${ }^{1}$ The assessment criterion on nonconcessional borrowing is defined to include these three SOEs. It excludes commercially viable companies, namely Portos e Caminhos de Ferro de Mocambique (the company in charge of the rail system and the country's five ports), LAM (the airline company), and CMH (the company in charge of exploration and processing of natural gas), as well as smaller public entities. In general, the statutes of SOEs require approval by the Minister of Finance on all commercial borrowing. A new Law on Public Enterprises will enhance the reporting of SOEs to the Minister of Finance (see MEFP q22). 
25. The authorities intend to broaden coverage of the budget. While at present the fiscal stance is measured on a central government basis, the

MEFP $\mid 19$ authorities will expeditiously work toward integrating the Road Fund, the water authority (FIPAG), and the electricity company (EDM) into their fiscal analysis. To this end, they will develop a fiscal template that will consolidate the revenue, expenditure, and financing of the central government and those entities, which should allow a regular reporting of quarterly consolidated fiscal accounts later this year. The planned Law on Public Enterprises will further stipulate the reporting requirements of SOEs to the government.

Adapting the borrowing strategy and improving decision making

MEFP $q 15-17$

26. The authorities firmly indicated that concessional financing would remain their preferred choice of financing. Nonetheless, they would assess the availability of other financing options - including the possibility of higher domestic borrowing and tapping nonconcessional external resources - to advance their public investment program in transportation and energy infrastructure. The authorities have informed development partners of their intention in this regard, reiterating that the accelerated infrastructure investments are additive to the existing development programs (especially health, education, capacity building) for which donor support will continue to be essential to help meet the country's development objectives.

\section{The fiscal program allows for higher domestic and external borrowing, over a} limited time horizon, to implement the high-priority infrastructure projects. Staff's analysis suggests that limited recourse to domestic financing of up to 1 percent of GDP per year and untied nonconcessional external borrowing averaging $2 \frac{1}{2}$ percent of GDP per year (a cumulative US $\$ 900$ million during the program period), with a commensurate increase in the overall fiscal deficit, could be consistent with macroeconomic stability and debt sustainability, using prudent assumptions on the growth dividend, the revenue response, and financing terms. ${ }^{6}$ The envisaged larger domestic financing is also expected to help develop domestic financial markets and leave sufficient room for the credit to the private sector.

\section{The accompanying debt sustainability analysis confirms Mozambique's low risk} of debt distress but identifies heightened vulnerabilities. While key debt indicators remain under the relevant debt burden thresholds under the Bank-Fund debt sustainability framework (DSF), the thresholds are temporarily exceeded under some stress tests. Consequently, the risk of the new borrowing needs to be carefully managed. To this end, the program includes important commitments to enhance the authorities' capacity to identify and implement priority projects and step up debt management (Box 6).

\footnotetext{
${ }^{6}$ For 2010, the authorities intend to tap nonconcessional financing from bilateral development banks to advance priority projects. Over the medium term, the choice of financing will be determined on the basis of the debt strategy that is being developed (see Box 6 below).
} 


\section{Box 6. Enhancing Investment Planning and Debt Management}

Building the capacity to manage risks related to borrowing on nonconcessional terms, the choice of investment projects, and the granting of concessions and PPPs will be a central focus under the program. TA from the Fund and the Bank has been lined up to support the authorities in these endeavors. The following structural reforms were agreed upon:

Debt strategy. By end-November 2010, the government will finalize a multi-year debt strategy (structural benchmark). Key elements of the strategy will include

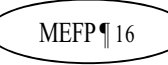
steps to derive an annual borrowing profile and calendar, lengthen the maturity structure to help extend the domestic yield curve, develop the institutional framework of domestic financial markets, and identify possible external financing options.

Debt management. The institutional framework for debt management will be enhanced to help the government make informed decisions about borrowing MEFP 17 options and the evaluation of possible risks. To this end, the debt unit in the ministry of finance (MOF) will receive additional staff and be supported in its work by the creation of a debt monitoring committee (DMC) with members of specialized services from other public institutions, such as the central bank. The beefed-up technical expertise will be a strong foundation for the authorities producing their first semiannual debt sustainability analysis (DSA). The first analysis will be completed and published by end-September 2010 (structural benchmark).

Investment planning. A new legal framework for PPPs and concessions will be adopted by the Council of Ministers by end-September 2010 (structural benchmark). The law is expected to follow best practices in terms of financial management, accounting, and risk sharing with the private sector. It will formalize the PPP approval process, introduce 'gateway' decision points whereby the consensus of the Ministry of Finance would be required before a PPP can proceed, and create a new PPP unit in the Ministry of Finance to support the gateway process and improve financial oversight of PPPs.

\section{Continuing with fiscal structural reforms to shore up public finance objectives}

\section{The government is determined to press ahead with reforms to shore up public}

finances. Based on extensive TA from the Fund and other development partners, the government will continue to implement measures to modernize tax policy and administration, strengthen PFM, and improve economic governance. Many of the measures are part of a multi-year effort that is also embedded in performance benchmarks under the harmonized donor support framework (Performance Assessment Framework, PAF).

\section{Containing inflation and strengthening the monetary policy framework}

30. Monetary policy will continue to aim at maintaining low inflation while making sufficient room for credit to the private sector. The BM aims to contain inflation to below 6 percent over the medium term, with a temporary spike to 9 percent in 2010 arising from spillovers of the removal of the fuel price subsidy. The BM remains committed to maintaining its flexible exchange rate regime, which has enabled it to successfully reduce inflation to single-digit levels and tackle the challenges from the scaling up of aid. This bodes well for the 
BM facing the new challenges from the increased external borrowing by the government to finance its investment program. In its management of the exchange rate, the BM will pay close attention to the effective exchange rate vis-àvis a broad basket of currencies, which should prevent a repeat of the temporary overvaluation of the exchange rate in 2008-09 that arose from a focus on the bilateral exchange rate with the U.S. dollar; this overvaluation has in the meantime been reversed.

31. The BM will continue to rely on reserve money as its operational target in the near future. Reserve money growth will be consistent with an assumed further strengthening in money demand and rising financial intermediation. However, the program target is now defined as a monthly average instead of an end-period stock so as to neutralize somewhat the end-month spike in currency demand when wages and salaries are being paid. Staff analysis suggests that this should enhance the ability of the BM to meet the program target.

\section{In 2010, the BM will aim to unwind the monetary expansion made necessary by} the global crisis, as private operators are expected to revert to their traditional external funding sources. As a result, a marked slowdown in credit to the private sector is projected for this year. As a first step, the BM increased its key policy rate (FPC) from $11 \frac{1}{2}$ to 12 $\frac{1}{2}$ percent in April 2010.

33. The BM will decide whether to move to an inflation targeting framework over the next two years. Based on significant Fund TA, the BM is in the process of tackling some of the prerequisites for a successful transition, as outlined in the relevant action plan. Specifically, the BM needs to: (i) decide which inflation rate will be targeted and what core inflation rate should be used to assess inflationary conditions $;^{7}$ (ii) enhance its monitoring, understanding, and capacity to project the monetary transmission mechanism; (iii) strengthen its monetary instruments to steer monetary conditions effectively; and (iv) improve its communications strategy with the private sector. The BM is also working on improving its liquidity demand forecasting to better capture the ongoing shift toward a banked economy, as banking services are gradually being rolled out throughout the country.

\section{With nonconcessional and domestic borrowing set to substantially increase} during the program period, liquidity and foreign exchange management will be particularly challenging. Capital inflows would tend to affect the exchange rate before spending is absorbed in investment-related imports. If the project implementation and related imports are not well timed with borrowing decisions, the lag could lead to temporary appreciation and excess liquidity. If prolonged, this would require selling reserves or issuing $\mathrm{t}-$ bills to sterilize the excess liquidity. Large inflows will therefore require greater sterilization and coordination between the BM and the government, and the implementation of a costsharing mechanism, which still need to be concluded. The BM will need to carefully balance its sterilization operations: while it has to ensure adequate foreign reserves to meet later debt

\footnotetext{
${ }^{7}$ The recent multi-topic STA mission concluded that there is a significant downward bias in the CPI, which the authorities need to address urgently, with bilateral technical assistance.
} 
service payments, the BM will also need to guard against excessive reserve accumulation that would limit the effective external absorption of capital inflows and constrain private sector credit growth.

35. The authorities are currently taking actions to remove the existing exchange restrictions on the making of payments and transfers for current international transactions subject to approval under Article VIII of the Fund's Articles of Agreement through adoption of foreign exchange regulations. Following the adoption of the foreign exchange law that came into effect on March 11, 2009, they have been working on the implementing regulations that are intended to remove the remaining exchange restrictions. While the drafting process of the implementing regulations has been delayed, as the authorities had reassigned staff to enhance the supervision of the financial sector in the wake of the global crisis, the adoption of the regulations is now near completion, since they are scheduled to be adopted by the Council of Ministers in August 2010, following consultations with the private sector (especially commercial banks) during June/July. The implementation regulations are intended to eliminate the remaining exchange restrictions on the making of payments and transfers for current international transactions, and staff will review the regulations in order to confirm this. The authorities have communicated to staff that they intend to accept their obligations under Article VIII of the Fund's Articles of Agreement following the issuance of the regulations.

\section{Safeguarding financial sector soundness}

36. Several steps will be implemented to strengthen the financial sector. The government and the BM will ensure expeditious follow-up on the recommendations of the 2009 Financial Sector Assessment Program (FSAP) update and recent TA. It will develop a Financial Sector Action Plan to implement the FSAP recommendations by end-July 2010, step-up risk management, and develop deposit insurance. Following rapid credit growth over the last two years, the BM will closely supervise activities in the banking system and encourage banks to develop a stress testing framework. Close attention will be devoted to assessing liquidity conditions and the quality of loan portfolios. Finally, the authorities intend to take important steps to make the AML/CFT framework more effective in the near future.

\section{Improving the business environment, economic governance, and statistics}

\section{The government intends to implement a broad range of} measures to improve the business environment, improve economic governance, and transparency. While they largely fall outside of the core area of expertise of the Fund, they are important to stimulate the hoped-for response of the private sector in boosting economic activity. Among other things, the authorities are working with the Bank on implementing a vast range of fast-track measures to ease red tape, streamline the granting of business-related licenses, improve bankruptcy proceedings, and facilitate trading across borders. They also reiterated their commitment to implement their action plan to enhance transparency and accountability in the natural resources sector to become a full member of EITI within the envisaged timeframe of two years, i.e., by May 2011. Finally, based on Fund 
TA, the government will improve its statistical system, particularly improving data quality of the quarterly national accounts, consumer prices index, government finance statistics, and megaprojects.

\section{Program Monitoring}

38. Three changes were made to the quantitative program targets under the successor PSI compared to the expiring PSI/ESF program (MEFP Table 1). First, the ceiling on nonconcessional borrowing is modified to allow untied external borrowing at larger amounts compared to the previous limits that were virtually nil, so as to support the authorities' development objectives. Second, the reserve money target is to be met henceforth on an average basis, which in light of intra-month volatility should help the BM's ability to observe the target. And third, an indicative floor on priority spending, as defined in the authorities' poverty reduction strategy PARPA, has been introduced to ensure that the expansion in the authorities' public investment program does not impair expenditure on PARPA objectives, such as in the areas of health and education.

\section{Staff ApPRAisal}

39. The Mozambican authorities are to be commended for the successful implementation of their first three-year PSI. Notwithstanding a difficult external environment-first the food and oil price shock and then the global financial crisis- the authorities were able to keep the economy on course through appropriate fiscal and monetary policies. Their traditionally prudent macroeconomic policy mix provided them with the necessary room to flexibly respond to these exogenous shocks. The authorities also made significant headways in implementing their structural reform agenda, including in particular related to PFM, tax policy and administration, the monetary policy framework, and financial sector supervision. Overall, Mozambique fits the characteristics of a mature stabilizer well, with its strong economic growth, low inflation, comfortable external reserves, and sustainable debt.

40. Mozambique has shown remarkable resilience to the global crisis. Its economic performance in 2009 was stronger than expected, notwithstanding the decline in export proceeds and private capital inflows. The domestic economy held up well under the circumstances, as the authorities appropriately loosened fiscal and monetary policies to support economic activity. In particular, an accommodating monetary policy helped substitute foreign borrowing with domestic credit at a crucial time. This, together with the traditional difficulties in predicting cash demand in a country that is transitioning toward a banked economy, contributed to the BM exceeding the reserve money target for end-December 2009. This has resulted in the need for a waiver, which the staff supports, as the BM is committed to restraining monetary growth in 2010. A strong revenue performance-reaping the rewards of past efforts to strengthen tax administration - kept automatic stabilizers small and resulted in a lower-than-anticipated domestic primary deficit. With the improved economic outlook, the authorities' plans to unwind in 2010 the policy easing from last year is appropriate. 
41. The authorities' intention to raise economic growth to achieve their development objectives while safeguarding macroeconomic stability is welcome, though not without risks. Increasing growth outside the megaprojects in the natural resources sector requires removing identified bottlenecks so that the private sector can develop and play its intended role as an engine for growth. The authorities' focus is on developing infrastructure in the energy and transport sectors, which is of paramount importance in this vast country. But this is not a panacea, as the infrastructure investment needs to be complemented with targeted measures to improve the business environment, develop sectoral growth strategies, and foster regional trade integration. It also crucially hinges on the authorities' commitment to preserve one of Mozambique's strongest assets - its strong track record of macroeconomic stability and low debt vulnerabilities. And it requires putting in place a modern framework for investment planning and PPPs that would be backed by best practices in terms of financial management, accounting, and risk sharing with the private sector. Moving too forcefully with the intended investment push could erode the gains of prior years and risks leaving the country worse off down the road.

\section{The successor PSI aims to strike a balance between addressing Mozambique's} daunting development needs and preserving macroeconomic stability. The program accommodates a temporary increase in public investment, partially financed through nonconcessional external borrowing, while keeping domestic demand pressures in check. At the same time, the authorities would need to significantly improve their ability for economic decision making with respect to selecting investment projects and their financing options. The program's structural reform focus on debt management - including the development of a coherent debt strategy and the finalization of the authorities' first own DSA - and on investment planning aims to quickly bring the authorities up to speed in this regard. In addition, a continued strong implementation record of fiscal structural reforms in the areas of PFM and tax policy and administration will help shore up the program's fiscal policy stance. The authorities are also encouraged to continue their efforts to improve liquidity forecasting and management, which should help their preparations for possibly adopting an inflation targeting framework during the program period.

\section{Based on program performance to date and the authorities' commitment to} program implementation, staff recommends: (i) completion of the sixth PSI review and the second review under the ESF arrangement; (ii) the waiver for the nonobservance of the end-December $2009 \mathrm{AC} / \mathrm{PC}$ on reserve money, as corrective action is being taken; and (iii) approval of the proposed successor three-year PSI covering the period 2010-13. 
Table 1. Mozambique: Selected Economic and Financial Indicators, 2008-15

\begin{tabular}{|c|c|c|c|c|c|c|c|c|c|c|}
\hline & \multirow{2}{*}{$\begin{array}{r}2008 \\
\text { Act. }\end{array}$} & \multicolumn{2}{|c|}{2009} & \multicolumn{2}{|l|}{2010} & \multirow[t]{2}{*}{2011} & \multirow{2}{*}{$\begin{array}{r}2012 \\
P\end{array}$} & 2013 & \multirow{2}{*}{2014} & \multirow[t]{2}{*}{2015} \\
\hline & & Prog. & Proj. & CR No. 09/327 & Proj. & & & rojections & & \\
\hline & \multicolumn{10}{|c|}{ (Annual percentage change, unless otherwise indicated) } \\
\hline \multicolumn{11}{|l|}{ National income and prices } \\
\hline Nominal GDP (MT billion) & 240 & 260 & 263 & 300 & 306 & 348 & 396 & 451 & 514 & 585 \\
\hline Nominal GDP growth & 15.5 & 8.2 & 9.8 & 15.5 & 16.3 & 13.6 & 13.9 & 13.9 & 13.8 & 13.9 \\
\hline Real GDP growth & 6.7 & 4.5 & 6.3 & 5.4 & 6.5 & 7.5 & 7.6 & 7.9 & 7.8 & 7.8 \\
\hline GDP per capita (US\$) & 478 & 445 & 465 & 471 & 473 & 488 & 542 & 604 & 657 & 699 \\
\hline Consumer price index (annual average) & 10.3 & 3.5 & 3.3 & 9.5 & 9.3 & 5.6 & 5.6 & 5.6 & 5.6 & 5.6 \\
\hline Consumer price index (end of period) & 6.2 & 5.4 & 4.2 & 8.0 & 8.0 & 5.6 & 5.6 & 5.6 & 5.6 & 5.6 \\
\hline \multicolumn{11}{|l|}{ External sector } \\
\hline Merchandise exports & 10.0 & -26.5 & -30.2 & 9.8 & 12.7 & 27.2 & 8.1 & 6.6 & 8.9 & 9.3 \\
\hline Merchandise exports, excluding megaprojects & 41.1 & -22.3 & -26.8 & 4.3 & 4.5 & 2.7 & 3.8 & 4.9 & 6.2 & 6.6 \\
\hline Merchandise imports & 29.6 & -10.0 & -11.0 & 0.8 & 10.7 & 13.1 & 9.6 & 9.3 & 8.7 & 9.1 \\
\hline Merchandise imports, excluding megaprojects & 34.7 & -6.4 & -16.7 & -1.7 & 14.5 & 16.1 & 10.9 & 10.4 & 9.0 & 10.1 \\
\hline Terms of trade & -3.9 & -12.7 & -8.5 & 4.3 & 1.5 & 12.0 & 0.1 & 0.4 & -1.2 & -3.5 \\
\hline Nominal effective exchange rate (end of period) & 11.1 & $\ldots$ & -4.0 & $\ldots$ & $\ldots$ & $\ldots$ & $\ldots$ & $\ldots$ & $\ldots$ & $\ldots$ \\
\hline \multirow[t]{2}{*}{ Real effective exchange rate (end of period) } & 11.8 & $\cdots$ & -3.2 & $\ldots$ & $\ldots$ & $\ldots$ & $\cdots$ & $\cdots$ & $\cdots$ & $\ldots$ \\
\hline & \multicolumn{10}{|c|}{ (Annual percentage change, unless otherwise indicated) } \\
\hline \multicolumn{11}{|l|}{ Money and credit } \\
\hline Reserve money & 7.8 & 18.0 & 27.3 & 16.0 & 19.5 & 14.7 & 15.0 & 15.1 & 14.9 & 15.0 \\
\hline M2 & 26.0 & 28.6 & 34.6 & 20.4 & 22.6 & 21.6 & 17.2 & 16.9 & 16.0 & 15.3 \\
\hline M3 (Broad Money) & 20.3 & 25.6 & 32.6 & 18.3 & 21.1 & 23.1 & 16.6 & 16.3 & 15.4 & 14.7 \\
\hline \multirow[t]{2}{*}{ Credit to the economy } & 45.9 & 44.6 & 58.6 & 17.8 & 19.1 & 14.0 & 14.9 & 15.8 & 15.7 & 15.8 \\
\hline & \multicolumn{10}{|c|}{ (Percent of GDP) } \\
\hline \multicolumn{11}{|l|}{ Investment and saving } \\
\hline Gross domestic investment & 15.7 & 15.9 & 21.0 & 19.7 & 25.2 & 26.0 & 26.9 & 27.2 & 27.3 & 27.3 \\
\hline Government & 11.6 & 11.7 & 13.1 & 13.6 & 13.9 & 14.3 & 14.6 & 14.6 & 14.8 & 15.0 \\
\hline Other sectors & 4.1 & 4.1 & 7.9 & 6.1 & 11.3 & 11.8 & 12.4 & 12.6 & 12.5 & 12.3 \\
\hline Gross domestic savings (excluding grants) & -4.0 & -1.9 & 2.0 & 0.4 & 4.6 & 5.5 & 5.9 & 6.3 & 6.8 & 7.1 \\
\hline Government & 0.3 & -1.3 & -0.4 & -0.3 & 1.2 & 1.2 & 1.5 & 1.9 & 2.1 & 2.4 \\
\hline Other sectors & -4.3 & -0.6 & 2.5 & 0.7 & 3.4 & 4.4 & 4.4 & 4.5 & 4.7 & 4.7 \\
\hline External current account, before grants & -19.7 & -17.8 & -18.9 & -19.3 & -20.6 & -20.5 & -21.0 & -20.9 & -20.4 & -20.2 \\
\hline External current account, after grants & -11.9 & -11.0 & -11.9 & -11.5 & -13.6 & -12.8 & -13.5 & -13.4 & -13.0 & -12.8 \\
\hline \multicolumn{11}{|l|}{ Government budget } \\
\hline Total revenue & 16.0 & 16.4 & 17.8 & 16.7 & 18.4 & 18.7 & 19.2 & 19.7 & 20.0 & 20.3 \\
\hline Total expenditure and net lending & 27.9 & 30.1 & 32.9 & 31.4 & 31.9 & 35.4 & 35.2 & 35.0 & 34.5 & 34.6 \\
\hline Overall balance, before grants & -11.8 & -13.7 & -15.2 & -14.7 & -13.5 & -16.7 & -16.1 & -15.3 & -14.5 & -14.2 \\
\hline Total grants & 9.4 & 9.3 & 9.6 & 10.8 & 8.8 & 9.4 & 9.3 & 9.2 & 9.2 & 9.2 \\
\hline Overall balance, after grants & -2.3 & -4.3 & -5.6 & -3.9 & -4.7 & -7.2 & -6.8 & -6.1 & -5.3 & -5.1 \\
\hline Domestic primary balance, before grants & -3.2 & -5.3 & -4.4 & -5.1 & -4.2 & -4.6 & -4.4 & -4.0 & -3.8 & -3.7 \\
\hline External financing (incl. debt relief) & 4.0 & 3.1 & 5.1 & 2.1 & 4.3 & 6.3 & 5.9 & 5.4 & 4.5 & 4.3 \\
\hline Net domestic financing & -1.7 & 0.8 & 0.3 & 1.8 & 0.3 & 0.9 & 0.9 & 0.7 & 0.8 & 0.8 \\
\hline Privatization & 0.0 & 0.4 & 0.2 & 0.0 & 0.1 & 0.0 & 0.0 & 0.0 & 0.0 & 0.0 \\
\hline & & & & (US\$ millions, un & less othe & vise indic & ated) & & & \\
\hline External current account, before grants & $-1,958$ & $-1,677$ & $-1,859$ & $-1,959$ & $-2,104$ & $-2,204$ & $-2,560$ & $-2,889$ & $-3,138$ & $-3,375$ \\
\hline External current account, after grants & $-1,179$ & $-1,034$ & $-1,171$ & $-1,167$ & $-1,391$ & $-1,380$ & $-1,646$ & $-1,858$ & $-2,001$ & $-2,140$ \\
\hline Overall balance of payments & 120 & 114 & 197 & -48 & 100 & 405 & 431 & 323 & 231 & 236 \\
\hline Net international reserves (end of period) ${ }^{1}$ & 1,644 & 1,758 & 1,834 & 1,711 & 1,930 & 2,334 & 2,766 & 3,088 & 3,320 & 3,556 \\
\hline Gross international reserves (end of period) ${ }^{1}$ & 1,660 & 1,929 & 2,012 & 1,904 & 2,128 & 2,530 & 2,959 & 3,278 & 3,476 & 3,652 \\
\hline Months of projected imports of goods and nonfactor services & 4.6 & 5.4 & 5.1 & 5.0 & 4.9 & 5.3 & 5.6 & 5.7 & 5.5 & 5.3 \\
\hline
\end{tabular}

Sources: Mozambican authorities; and IMF staff estimates and projections.

${ }^{1}$ Includes disbursements of IMF resources under the ESF and August 2009 SDR allocation. 
Table 2. Mozambique: Government Finances, 2008-15

(MT Billions)

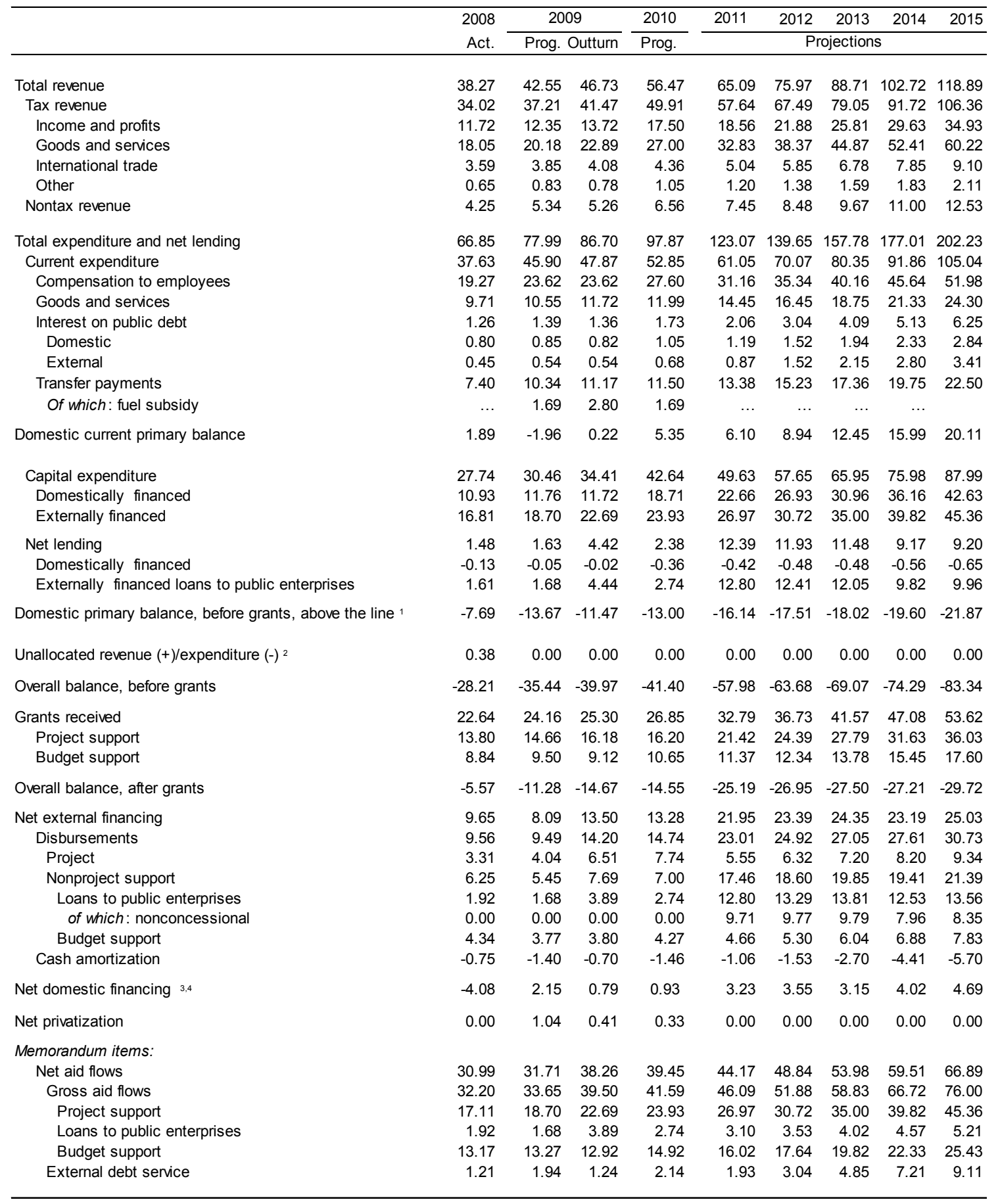

Sources: Mozambican authorities; and IMF staff estimates and projections.

${ }^{1}$ Revenue minus noninterest current expenditure minus locally financed capital expenditure and locally financed net lending.

2 Residual discrepancy between identified sources and uses of funds. For 2009, reflects expenditure initiated outside the PFM IT

regularized later.

3 Excludes recapitilization bonds issued to the Bank of Mozambique.

${ }_{4}^{4}$ A World Bank disbursement of US $\$ 80$ (US\$110) million budget support designated for 2009 (2010) was advanced to 2008 (2009). 
Table 3. Mozambique: Government Finances, 2008-15 (Percent of GDP)

\begin{tabular}{|c|c|c|c|c|c|c|c|c|c|}
\hline & \multirow{2}{*}{$\begin{array}{l}2008 \\
\text { Act. }\end{array}$} & \multicolumn{2}{|c|}{2009} & \multirow{2}{*}{$\begin{array}{c}2010 \\
\text { Prog. }\end{array}$} & \multirow[t]{2}{*}{2011} & 2012 & 2013 & \multirow[t]{2}{*}{2014} & \multirow[t]{2}{*}{2015} \\
\hline & & Prog. & Est. & & & \multicolumn{2}{|c|}{ Projections } & & \\
\hline Total revenue & 16.0 & 16.4 & 17.8 & 18.4 & 18.7 & 19.2 & 19.7 & 20.0 & 20.3 \\
\hline Tax revenue & 14.2 & 14.3 & 15.8 & 16.3 & 16.6 & 17.0 & 17.5 & 17.9 & 18.2 \\
\hline Nontax revenue & 1.8 & 2.1 & 2.0 & 2.1 & 2.1 & 2.1 & 2.1 & 2.1 & 2.1 \\
\hline Total expenditure and net lending & 27.9 & 30.1 & 32.9 & 32.0 & 35.4 & 35.2 & 35.0 & 34.5 & 34.6 \\
\hline Current expenditure & 15.7 & 17.7 & 18.2 & 17.3 & 17.5 & 17.7 & 17.8 & 17.9 & 18.0 \\
\hline Compensation to employees & 8.0 & 9.1 & 9.0 & 9.0 & 9.0 & 8.9 & 8.9 & 8.9 & 8.9 \\
\hline Goods and services & 4.0 & 4.1 & 4.5 & 3.9 & 4.2 & 4.2 & 4.2 & 4.2 & 4.2 \\
\hline Interest on public debt & 0.5 & 0.5 & 0.5 & 0.6 & 0.6 & 0.8 & 0.9 & 1.0 & 1.1 \\
\hline Transfer payments & 3.1 & 4.0 & 4.2 & 3.8 & 3.8 & 3.8 & 3.8 & 3.8 & 3.8 \\
\hline Of which: fuel subsidy & $\ldots$ & 0.6 & 1.1 & 0.6 & $\ldots$ & $\ldots$ & $\ldots$ & $\ldots$ & \\
\hline Domestic current primary balance & 0.8 & -0.8 & 0.1 & 1.7 & 1.8 & 2.3 & 2.8 & 3.1 & 3.4 \\
\hline Capital expenditure & 11.6 & 11.7 & 13.1 & 13.9 & 14.3 & 14.6 & 14.6 & 14.8 & 15.0 \\
\hline Domestically financed & 4.6 & 4.5 & 4.5 & 6.1 & 6.5 & 6.8 & 6.9 & 7.0 & 7.3 \\
\hline Externally financed & 7.0 & 7.2 & 8.6 & 7.8 & 7.8 & 7.8 & 7.8 & 7.8 & 7.8 \\
\hline Net lending & 0.6 & 0.6 & 1.7 & 0.8 & 3.6 & 3.0 & 2.5 & 1.8 & 1.6 \\
\hline Domestically financed & -0.1 & 0.0 & 0.0 & -0.1 & -0.1 & -0.1 & -0.1 & -0.1 & -0.1 \\
\hline Externally financed loans to public enterprises & 0.7 & 0.6 & 1.7 & 0.9 & 3.7 & 3.1 & 2.7 & 1.9 & 1.7 \\
\hline Domestic primary balance, before grants, above the line ${ }^{1}$ & -3.2 & -5.3 & -4.4 & -4.2 & -4.6 & -4.4 & -4.0 & -3.8 & -3.7 \\
\hline Unallocated revenue $(+)$ /expenditure $(-)^{2}$ & 0.2 & 0.0 & 0.0 & 0.0 & 0.0 & 0.0 & 0.0 & 0.0 & 0.0 \\
\hline Domestic primary balance & -3.9 & -5.3 & -4.4 & -4.2 & -4.6 & -4.4 & -4.0 & -3.8 & -3.7 \\
\hline Overall balance, before grants & -11.8 & -13.7 & -15.2 & -13.5 & -16.7 & -16.1 & -15.3 & -14.5 & -14.2 \\
\hline Grants received & 9.4 & 9.3 & 9.6 & 8.8 & 9.4 & 9.3 & 9.2 & 9.2 & 9.2 \\
\hline Project & 5.8 & 5.7 & 6.1 & 5.3 & 6.2 & 6.2 & 6.2 & 6.2 & 6.2 \\
\hline Nonproject & 3.7 & 3.7 & 3.5 & 3.5 & 3.3 & 3.1 & 3.1 & 3.0 & 3.0 \\
\hline Overall balance, after grants & -2.3 & -4.3 & -5.6 & -4.7 & -7.2 & -6.8 & -6.1 & -5.3 & -5.1 \\
\hline Net external financing & 4.0 & 3.1 & 5.1 & 4.3 & 6.3 & 5.9 & 5.4 & 4.5 & 4.3 \\
\hline Disbursements & 4.0 & 3.7 & 5.4 & 4.8 & 6.6 & 6.3 & 6.0 & 5.4 & 5.3 \\
\hline Project & 1.4 & 1.6 & 2.5 & 2.5 & 1.6 & 1.6 & 1.6 & 1.6 & 1.6 \\
\hline Nonproject support & 2.6 & 2.1 & 2.9 & 2.3 & 5.0 & 4.7 & 4.4 & 3.8 & 3.7 \\
\hline Loans to public enterprises & 0.8 & 0.6 & 1.5 & 0.9 & 3.7 & 3.4 & 3.1 & 2.4 & 2.3 \\
\hline of which: nonconcessional & 0.0 & 0.0 & 0.0 & 0.0 & 2.8 & 2.5 & 2.2 & 1.6 & 1.4 \\
\hline Budget support & 1.8 & 1.5 & 1.4 & 1.4 & 1.3 & 1.3 & 1.3 & 1.3 & 1.3 \\
\hline Cash amortization & -0.3 & -0.5 & -0.3 & -0.5 & -0.3 & -0.4 & -0.6 & -0.9 & -1.0 \\
\hline Net domestic financing ${ }^{3,4}$ & -1.7 & 0.8 & 0.3 & 0.3 & 0.9 & 0.9 & 0.7 & 0.8 & 0.8 \\
\hline Net privatization & 0.0 & 0.4 & 0.2 & 0.1 & 0.0 & 0.0 & 0.0 & 0.0 & 0.0 \\
\hline \multicolumn{10}{|l|}{ Memorandum items: } \\
\hline Net aid flows & 12.9 & 12.2 & 14.5 & 12.9 & 12.7 & 12.3 & 12.0 & 11.6 & 11.4 \\
\hline Gross aid flows & 13.4 & 13.0 & 15.0 & 13.6 & 13.2 & 13.1 & 13.0 & 13.0 & 13.0 \\
\hline Budget support & 5.5 & 5.1 & 4.9 & 4.9 & 4.6 & 4.5 & 4.4 & 4.3 & 4.3 \\
\hline Project support & 7.1 & 7.2 & 8.6 & 7.8 & 7.8 & 7.8 & 7.8 & 7.8 & 7.8 \\
\hline Loans to public enterprises & 0.8 & 0.6 & 1.5 & 0.9 & 0.9 & 0.9 & 0.9 & 0.9 & 0.9 \\
\hline External debt service & 0.5 & 0.7 & 0.5 & 0.7 & 0.6 & 0.8 & 1.1 & 1.4 & 1.6 \\
\hline
\end{tabular}

Sources: Mozambican authorities; and IMF staff estimates and projections.

$1 /$ Includes costs of monetary policy transferred to the Bank

${ }^{1}$ Revenue minus noninterest current expenditure, financed capital expenditure, and locally financed net lending.

${ }_{2}^{2}$ Residual discrepancy between identified sources and uses of funds.

${ }^{3}$ Excludes recapitilization bonds issued to the Bank of Mozambique.

${ }^{4} \mathrm{~A}$ World Bank disbursement of US $\$ 80$ (US\$110) million budget support designated for 2009 (2010) was advanced to 2008 (2009). 
Table 4. Mozambique: Monetary Survey, Quarterly, 2008-10 1

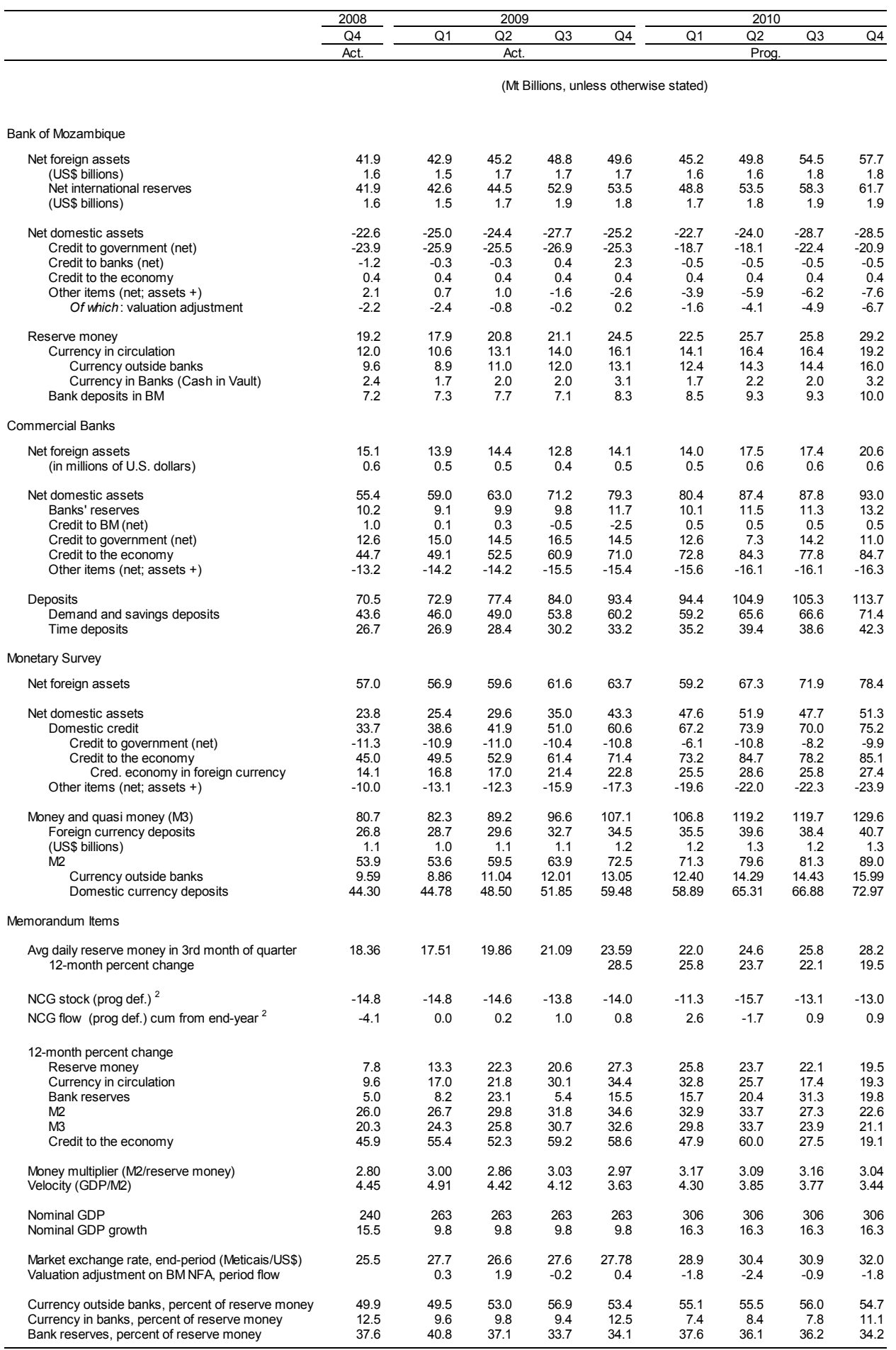

Sources: Bank of Mozambique; and IMF staff estimates and projections.

${ }^{1}$ Includes disbursements of Fund resources under the ESF and the August 2009 SDR allocation

${ }^{2}$ As defined in the TMU, this equals the NCG in the monetary survey excluding Moatize deposits, earmarked donor funds, and bonds issued to capitalize the BM.

${ }^{3}$ As defined in the TMU, this equals the NIR in the BM accounts evaluated at the program exchange rates versus the U.S. dollar specified in Table 1 of the TMU. 
Table 5. Mozambique: Balance of Payments, 2008-15

(Millions of U.S. dollars, unless otherwise specified)

\begin{tabular}{|c|c|c|c|c|c|c|c|c|c|}
\hline & \multirow{2}{*}{$\frac{2008}{\text { Actual }}$} & \multicolumn{2}{|c|}{2009} & \multirow{2}{*}{$\frac{2010}{\text { Proj. }}$} & 2011 & 2012 & 2013 & 2014 & 2015 \\
\hline & & Prog. & Act. & & \multicolumn{5}{|c|}{ Projections } \\
\hline Current account balance & $-1,179$ & $-1,034$ & $-1,171$ & $-1,391$ & $-1,380$ & $-1,646$ & $-1,858$ & $-2,001$ & $-2,140$ \\
\hline Trade balance for goods & -990 & $-1,328$ & $-1,390$ & $-1,500$ & $-1,403$ & $-1,575$ & $-1,799$ & $-1,949$ & $-2,121$ \\
\hline Of which: Megaprojects & 1,150 & 802 & 474 & 693 & 1,226 & 1,386 & 1,506 & 1,673 & 1,892 \\
\hline Exports, f.o.b. & 2,653 & 1,951 & 1,853 & 2,089 & 2,656 & 2,872 & 3,062 & 3,334 & 3,645 \\
\hline Of which: Megaproject exports & 1,851 & 1,328 & 1,265 & 1,474 & 2,026 & 2,217 & 2,375 & 2,605 & 2,868 \\
\hline Imports, f.o.b. & $-3,643$ & $-3,279$ & $-3,243$ & $-3,589$ & $-4,059$ & $-4,447$ & $-4,861$ & $-5,283$ & $-5,766$ \\
\hline Of which: Megaproject imports & -702 & -526 & -791 & -782 & -800 & -832 & -869 & -932 & -976 \\
\hline Trade balance for services & -410 & -411 & -450 & -451 & -495 & -561 & -637 & -707 & -768 \\
\hline Income balance & -631 & -63 & -95 & -233 & -390 & -520 & -561 & -602 & -617 \\
\hline Of which: Dividend payments by megaprojects & -492 & -23 & -17 & -220 & -369 & -477 & -496 & -518 & -518 \\
\hline Current transfers balance & 852 & 768 & 764 & 793 & 908 & 1,010 & 1,139 & 1,257 & 1,365 \\
\hline Of which: External grants & 778 & 643 & 687 & 713 & 824 & 914 & 1,031 & 1,137 & 1,235 \\
\hline Capital and financial account balance & 1,188 & 1,188 & 1,439 & 1,491 & 1,785 & 2,077 & 2,181 & 2,232 & 2,376 \\
\hline Capital account balance & 420 & 432 & 422 & 371 & 391 & 442 & 503 & 558 & 606 \\
\hline Financial account balance & 768 & 756 & 1,016 & 1,119 & 1,394 & 1,635 & 1,678 & 1,674 & 1,770 \\
\hline Net foreign direct investment & 587 & 532 & 878 & 917 & 732 & 748 & 802 & 908 & 1,016 \\
\hline Net foreign borrowing by the general government & 342 & 354 & 434 & 583 & 836 & 865 & 881 & 817 & 771 \\
\hline Net foreign borrowing by the nonfinancial private sector & -97 & -247 & -456 & -203 & -37 & 227 & 227 & 207 & 264 \\
\hline Other $^{1}$ & -64 & 116 & 160 & -177 & -137 & -205 & -233 & -258 & -280 \\
\hline Of which: Special drawing rights & 0 & 169 & 170 & 0 & 0 & 0 & 0 & 0 & 0 \\
\hline Net errors and omissions & 112 & -40 & -70 & 0 & 0 & 0 & 0 & 0 & 0 \\
\hline Overall balance & 120 & 114 & 197 & 100 & 405 & 431 & 323 & 231 & 236 \\
\hline External financing & -120 & -114 & -197 & -100 & -405 & -431 & -323 & -231 & -236 \\
\hline Reserve assets ${ }^{1,2}$ & -140 & -269 & -352 & -120 & -403 & -428 & -320 & -198 & -175 \\
\hline Net use of Fund credit ${ }^{2}$ & 0 & 155 & 152 & 20 & -2 & -3 & -3 & -34 & -61 \\
\hline Exceptional financing & 19 & 1 & 2 & 0 & 0 & 0 & 0 & 0 & 0 \\
\hline \multicolumn{10}{|l|}{ Memorandum items: } \\
\hline \multicolumn{10}{|l|}{ Effective exchange rate indexes (percent change) } \\
\hline Nominal effective exchange rate & 11.1 & $\ldots$ & -4.0 & $\ldots$ & $\ldots$ & $\ldots$ & $\ldots$ & $\ldots$ & $\ldots$ \\
\hline Real effective exchange rate & 11.8 & $\ldots$ & -3.2 & $\ldots$ & $\cdots$ & $\ldots$ & $\ldots$ & $\ldots$ & $\ldots$ \\
\hline Terms of trade index (percent change) & -3.9 & -12.7 & -8.5 & 1.5 & 12.0 & 0.1 & 0.4 & -1.2 & -3.5 \\
\hline International aluminum price & -2.3 & -37.9 & -35.8 & 14.8 & 10.5 & 9.5 & 4.3 & 4.2 & 0.0 \\
\hline International food price index & 23.4 & -14.9 & -14.7 & 2.7 & -0.4 & 0.4 & 0.7 & 0.4 & 0.2 \\
\hline International fuel price index & 40.1 & -37.2 & -36.4 & 19.9 & 7.5 & 3.3 & 2.1 & 2.5 & 2.4 \\
\hline Current account balance (percent of GDP) & -11.9 & -11.0 & -11.9 & -13.6 & -12.8 & -13.5 & -13.4 & -13.0 & -12.8 \\
\hline Excluding external grants & -19.7 & -17.8 & -18.9 & -20.6 & -20.5 & -21.0 & -20.9 & -20.4 & -20.2 \\
\hline Gross aid inflows (percent of GDP) & 14.3 & 13.8 & 16.0 & 14.8 & 14.5 & 14.2 & 14.0 & 13.9 & 13.8 \\
\hline Of which: To central government & 13.4 & 13.8 & 15.0 & 13.5 & 13.2 & 13.1 & 13.0 & 13.0 & 13.0 \\
\hline Budget support & 5.5 & 5.3 & 4.9 & 4.9 & 4.6 & 4.5 & 4.4 & 4.3 & 4.3 \\
\hline Project support & 7.1 & 7.5 & 8.6 & 7.8 & 7.8 & 7.8 & 7.8 & 7.8 & 7.8 \\
\hline Onlending & 0.8 & 1.0 & 1.5 & 0.9 & 0.9 & 0.9 & 0.9 & 0.9 & 0.9 \\
\hline Net foreign assets & 1,642 & 1,610 & 1,701 & 1,800 & 2,205 & 2,636 & 2,959 & 3,191 & 3,427 \\
\hline Net international reserves ${ }^{1,2}$ & 1,644 & 1,758 & 1,834 & 1,930 & 2,334 & 2,766 & 3,088 & 3,320 & 3,556 \\
\hline Gross international reserves 1,2 & 1,660 & 1,929 & 2,012 & 2,128 & 2,530 & 2,959 & 3,278 & 3,476 & 3,652 \\
\hline Months of projected imports of goods and nonfactor services & 4.6 & 5.4 & 5.1 & 4.9 & 5.3 & 5.6 & 5.7 & 5.5 & 5.3 \\
\hline Months of current imports of goods and nonfactor services & 4.3 & 5.4 & 5.6 & 5.4 & 5.8 & 6.2 & 6.2 & 6.0 & 5.8 \\
\hline
\end{tabular}

Sources: Data from Government of Mozambique and projections by IMF staff.

'Accounts for disbursement of an SDR allocation of SDR 108.8 million in 2009 Q3 above the line under other investment liabilities of the monetary authorities, and below the line as an increase in reserve assets.

${ }^{2}$ Based on an ESF-HAC arrangement of SDR 113.6 million (100 percent of quota) to be disbursed in three tranches: SDR 85.2 million (75 percent of quota) already disbursed follow ing completion of the fourth PSI review and approval of the ESF arrangement; SDR 14.2 million (12.5 percent of quota) already disbursed follow ing completion of the fifth PSI and first ESF review; and SDR 14.2 million (12.5 percent of quota) to be disbursed upon completion of the sixth PSI and second ESF review. 
Table 6. Mozambique: Indicators of Capacity to Repay the Fund

\begin{tabular}{|c|c|c|c|c|c|c|c|c|c|c|c|c|c|}
\hline & \multicolumn{11}{|c|}{ Projection } & \multirow[b]{2}{*}{2020} & \multirow[b]{2}{*}{ Total } \\
\hline & 2009 & 2010 & 2011 & 2012 & 2013 & 2014 & 2015 & 2016 & 2017 & 2018 & 2019 & & \\
\hline Fund obligations based on existing credit & 0.2 & 1.5 & 2.3 & 3.0 & 3.0 & 33.5 & 32.3 & 31.5 & 30.8 & 30.8 & 0.0 & 0.0 & \\
\hline Principal (millions of SDRs) & 0.2 & 1.0 & 1.5 & 1.9 & 1.9 & 21.7 & 20.9 & 20.4 & 19.9 & 19.9 & 0.0 & 0.0 & 109.1 \\
\hline Charges and interest (millions of SDRs) & 0.0 & 0.0 & 0.0 & 0.3 & 0.3 & 0.3 & 0.2 & 0.2 & 0.1 & 0.1 & 0.0 & 0.0 & 1.4 \\
\hline \multicolumn{14}{|l|}{ Fund obligations based on existing and prospective credit ${ }^{1}$} \\
\hline Principal (millions of SDRs) & 0.2 & 1.0 & 1.5 & 1.9 & 1.9 & 21.7 & 39.3 & 43.1 & 42.6 & 42.6 & 22.7 & 4.3 & 222.7 \\
\hline Charges and interest (millions of SDRs) & 0.2 & 0.5 & 0.6 & 0.8 & 0.8 & 0.8 & 0.7 & 0.6 & 0.4 & 0.2 & 0.1 & 0.0 & 5.8 \\
\hline \multicolumn{14}{|l|}{ Total obligations based on existing and prospective credit ${ }^{1}$} \\
\hline In millions of SDRs & 0.4 & 1.5 & 2.0 & 2.8 & 2.8 & 22.5 & 40.0 & 43.6 & 43.0 & 42.8 & 22.8 & 4.3 & $\ldots$ \\
\hline In millions of U.S. dollars & 0.6 & 2.3 & 3.1 & 4.3 & 4.3 & 34.8 & 62.0 & 67.6 & 66.5 & 66.3 & 35.2 & 6.6 & $\ldots$ \\
\hline In percent of exports of goods and services & 0.0 & 0.1 & 0.1 & 0.1 & 0.1 & 0.8 & 1.3 & 1.3 & 1.1 & 1.0 & 0.5 & 0.1 & $\ldots$ \\
\hline In percent of debt service & 1.3 & 3.3 & 4.2 & 3.5 & 2.2 & 12.7 & 17.1 & 16.2 & 14.6 & 13.7 & 6.8 & 1.3 & $\ldots$ \\
\hline In percent of GDP & 0.0 & 0.0 & 0.0 & 0.0 & 0.0 & 0.2 & 0.4 & 0.4 & 0.3 & 0.3 & 0.1 & 0.0 & $\ldots$ \\
\hline In percent of gross international reserves & 0.0 & 0.1 & 0.1 & 0.1 & 0.1 & 1.0 & 1.7 & 1.8 & 1.8 & 1.6 & 0.8 & 0.1 & $\ldots$ \\
\hline In percent of quota & 0.4 & 1.3 & 1.8 & 2.5 & 2.4 & 19.8 & 35.2 & 38.4 & 37.9 & 37.7 & 20.0 & 3.8 & $\ldots$ \\
\hline \multicolumn{14}{|l|}{ Outstanding Fund credit } \\
\hline In millions of SDRs & 109.1 & 123.2 & 122.2 & 120.8 & 118.8 & 116.9 & 96.6 & 72.9 & 49.7 & 27.0 & 4.3 & 0.0 & $\ldots$ \\
\hline In millions of U.S. dollars & 168.4 & 190.9 & 188.9 & 186.7 & 183.8 & 180.8 & 149.5 & 112.8 & 76.9 & 41.8 & 6.6 & 0.0 & $\ldots$ \\
\hline In percent of exports of goods and services & 6.8 & 7.0 & 5.7 & 5.1 & 4.7 & 4.2 & 3.2 & 2.2 & 1.3 & 0.6 & 0.1 & 0.0 & $\ldots$ \\
\hline In percent of debt service & 342.4 & 265.3 & 251.2 & 151.2 & 95.5 & 66.2 & 41.4 & 27.1 & 16.9 & 8.6 & 1.3 & 0.0 & $\ldots$ \\
\hline In percent of GDP & 1.7 & 1.9 & 1.8 & 1.5 & 1.3 & 1.2 & 0.9 & 0.6 & 0.4 & 0.2 & 0.0 & 0.0 & $\ldots$ \\
\hline In percent of gross international reserves & 8.4 & 9.0 & 7.5 & 6.3 & 5.6 & 5.2 & 4.1 & 3.1 & 2.0 & 1.0 & 0.1 & 0.0 & $\ldots$ \\
\hline In percent of quota & 96.1 & 108.4 & 107.6 & 106.3 & 104.6 & 102.9 & 85.0 & 64.2 & 43.8 & 23.8 & 3.8 & 0.0 & $\ldots$ \\
\hline Net use of Fund credit (millions of SDRs) & 85.0 & 27.4 & -1.5 & -1.9 & -1.9 & -21.7 & -39.3 & -43.1 & -42.6 & -42.6 & -22.7 & -4.3 & -109.1 \\
\hline Disbursements 1 & 85.2 & 28.4 & 0.0 & 0.0 & 0.0 & 0.0 & 0.0 & 0.0 & 0.0 & 0.0 & 0.0 & 0.0 & 113.6 \\
\hline Repayments & 0.2 & 1.0 & 1.5 & 1.9 & 1.9 & 21.7 & 39.3 & 43.1 & 42.6 & 42.6 & 22.7 & 4.3 & 222.7 \\
\hline \multicolumn{14}{|l|}{ Memorandum items: } \\
\hline Nominal GDP (millions of U.S. dollars) & 9831 & 10212 & 10750 & 12169 & 13830 & 15353 & 16670 & 18326 & 20240 & 22352 & 24675 & 27244 & $\ldots$ \\
\hline Exports of goods and nonfactor services (millions of U.S. dollars) & 2464 & 2741 & 3322 & 3626 & 3919 & 4285 & 4678 & 5232 & 5926 & 6696 & 7431 & 8218 & $\ldots$ \\
\hline External PPG debt service (millions of U.S. dollars) & 49 & 72 & 75 & 124 & 193 & 273 & 362 & 416 & 455 & 484 & 522 & 526 & $\ldots$ \\
\hline Gross international reserves (millions of U.S. dollars) 1, $^{2}$ & 2012 & 2128 & 2530 & 2959 & 3278 & 3476 & 3652 & 3659 & 3789 & 4130 & 4637 & 5411 & $\ldots$ \\
\hline Quota (millions of SDRs) & 113.6 & 113.6 & 113.6 & 113.6 & 113.6 & 113.6 & 113.6 & 113.6 & 113.6 & 113.6 & 113.6 & 113.6 & $\ldots$ \\
\hline SDR exchange rate (SDR/USD) & 0.65 & 0.65 & 0.65 & 0.65 & 0.65 & 0.65 & 0.65 & 0.65 & 0.65 & 0.65 & 0.65 & 0.65 & $\ldots$ \\
\hline
\end{tabular}

Sources: Data from Government of Mozambique and projections by IMF staff.

${ }^{1}$ Based on an ESF-HAC arrangement of SDR 113.6 million (100 percent of quota) to be disbursed in three tranches: SDR 85.2 million (75 percent of quota) already disbursed follow ing completion of the fourth PSI review and approval of the ESF arrangement; SDR 14.2 million (12.5 percent of quota) to be disbursed upon completion of the fifth PSI and first ESF review ; and SDR 14.2 million (12.5 percent of quota) to be disbursed upon completion of the sixth PSI and second ESF review.

${ }^{2}$ Accounts for disbursement of an SDR allocation of SDR 108.8 million in 2009Q3. The projected interest obligations do not incorporate the expected temporary interest relief and new structure of interest rates. 
Table 7. Mozambique: Financial Soundness Indicators for Banking Sector, 2001-09 (Percent unless otherwise indicated)

\begin{tabular}{|c|c|c|c|c|c|c|c|c|c|c|c|c|}
\hline & 2001 & 2002 & 2003 & 2004 & 2005 & 2006 & 2007 & 2008 & Mar-09 & Jun-09 & Sep-09 & Dec-09 \\
\hline \multicolumn{13}{|l|}{ Capital adequacy } \\
\hline Regulatory capital to risk-weighted assets & 5.5 & 14.0 & 17.0 & 18.7 & 16.0 & 12.5 & 14.2 & 13.9 & 17.0 & 18.1 & 16.6 & 15.1 \\
\hline Regulatory Tier I capital to risk-weighted assets & 6.0 & 12.0 & 14.7 & 16.0 & 13.6 & 10.7 & 12.3 & 12.4 & 14.9 & 16.2 & 14.3 & 13.0 \\
\hline Capital (net worth) to assets & 8.2 & 9.4 & 9.0 & 9.5 & 8.0 & 6.1 & 6.4 & 6.7 & 8.2 & 8.1 & 8.4 & 7.7 \\
\hline \multicolumn{13}{|l|}{ Asset composition and quality } \\
\hline \multicolumn{13}{|l|}{ Sectoral distribution of loans to total loans } \\
\hline Agriculture & 18.0 & 15.0 & 12.7 & 9.5 & 8.5 & 6.4 & 9.4 & 8.1 & 7.7 & 8.0 & 6.9 & 7.0 \\
\hline Industry & 25.0 & 22.0 & 16.9 & 11.9 & 16.8 & 22.2 & 19.5 & 16.7 & 21.8 & 19.3 & 17.7 & 15.4 \\
\hline Construction & 4.0 & 4.0 & 5.2 & 3.4 & 4.1 & 5.6 & 5.7 & 4.2 & 4.7 & 5.1 & 4.9 & 6.4 \\
\hline Commerce & 20.0 & 17.0 & 18.1 & 21.3 & 27.4 & 27.4 & 24.4 & 25.6 & 24.7 & 22.9 & 19.6 & 23.4 \\
\hline Transportation and communication & 7.0 & 5.0 & 7.1 & 7.2 & 5.8 & 6.2 & 12.2 & 11.2 & 12.4 & 11.6 & 13.8 & 12.2 \\
\hline Other & 27.0 & 36.0 & 37.1 & 36.2 & 35.1 & 32.3 & 28.7 & 34.2 & 28.7 & 28.5 & 37.1 & 35.7 \\
\hline of which: Private $1 /$ & & & 7.6 & 12.1 & 13.0 & 13.5 & 14.4 & 19.9 & 17.3 & 18.1 & 12.5 & 16.7 \\
\hline Housing & & & 7.1 & 8.2 & 4.2 & 4.1 & 3.7 & 3.7 & 3.7 & 3.5 & 2.8 & 2.9 \\
\hline Diverse $2 /$ & & & 22.4 & 15.9 & 17.8 & 14.7 & 10.6 & 10.0 & 7.2 & 6.9 & 14.8 & 15.9 \\
\hline Foreign exchange loans to total loans & 64.7 & 69.9 & 70.8 & 67.3 & 63.9 & 45.0 & 31.5 & 40.1 & 36.1 & 33.1 & 36.2 & 32.4 \\
\hline Nonperforming loans to gross loans $3 /$ & 23.4 & 22.0 & 14.4 & 6.4 & 3.8 & 3.3 & 0.9 & 2.0 & 2.0 & 2.2 & 2.0 & 2.0 \\
\hline Nonperforming loans net of provisions to capital $3 /$ & 11.0 & 9.4 & 7.9 & 1.7 & 0.9 & 2.2 & 15.5 & 12.2 & 11.0 & 5.5 & 5.3 & 5.3 \\
\hline \multicolumn{13}{|l|}{ Earnings and profitability } \\
\hline Return on assets & 0.1 & 1.6 & 1.2 & 1.4 & 1.8 & 3.5 & 1.9 & 3.5 & 0.9 & 1.6 & 3.1 & 3.0 \\
\hline Return on equity & 3.5 & 22.1 & 16.3 & 18.7 & 27.4 & 55.4 & 25.1 & 40.7 & 1.8 & 18.1 & 37.0 & 36.6 \\
\hline Interest margin to gross income & 10.2 & 61.4 & 56.8 & 60.2 & 58.0 & 63.1 & 56.2 & 57.0 & 57.0 & 57.6 & 57.4 & 55.7 \\
\hline Noninterest expenses to gross income & 16.9 & 67.0 & 72.2 & 71.2 & 65.9 & 54.1 & 58.3 & 61.1 & 59.1 & 59.1 & 59.0 & 58.4 \\
\hline Personnel expenses to noninterest expenses & 51.7 & 44.7 & 45.7 & 45.2 & 45.4 & 44.4 & 44.4 & 45.3 & 47.3 & 46.6 & 46.4 & 45.9 \\
\hline Trading and fee income to gross income & 33.1 & 39.7 & 45.5 & 41.9 & 43.8 & 32.2 & 43.4 & 43.0 & 43.0 & 40.8 & 41.5 & 43.5 \\
\hline Spread between reference loan and deposit rates (90 days, local curren & 14.0 & 19.0 & 17.4 & 14.7 & 11.5 & 14.6 & 11.2 & 10.7 & 10.6 & 11.0 & 11.0 & 11.1 \\
\hline \multicolumn{13}{|l|}{ Funding and liquidity } \\
\hline Liquid assets to total assets $4 /$ & 34.6 & 53.9 & 57.7 & 58.1 & 55.5 & 51.9 & 53.3 & 49.3 & 34.8 & 32.2 & 30.3 & 28.2 \\
\hline Customer deposits to total (non-interbank) loans & 217.0 & 240.0 & 228.0 & 283.1 & 191.9 & 179.3 & 198.2 & 170.6 & 158.6 & 155.4 & 147.9 & 138.2 \\
\hline Foreign exchange liabilities to total liabilities & 63.3 & 61.3 & 46.4 & 41.4 & 45.3 & 42.8 & 35.5 & 32.2 & 28.5 & 27.6 & 34.9 & 33.6 \\
\hline
\end{tabular}

1/ Includes credit cards and consumer credit lines for vehicle and durable goods.

2/ Includes credit to all other sectors not discriminated above or yet to be identified.

$3 /$ Nonperforming loans are defined according to Mozambican accounting standards (they include only part of the past-due loans).

4/ Includes deposits at parent banks. 
Table 8. Mozambique: Quantitative Assessment and Performance Criteria and Indicative Targets 1/ (Millions of meticais, unless otherwise specified)

\begin{tabular}{|c|c|c|c|c|c|c|c|}
\hline \multirow{3}{*}{\multicolumn{2}{|c|}{ 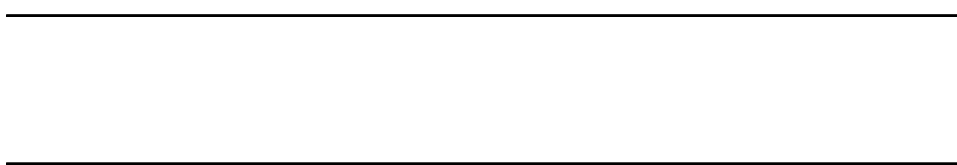 }} & \multicolumn{2}{|l|}{2009} & \multicolumn{4}{|c|}{2010} \\
\hline & & $\begin{array}{c}\text { End-Sept } \\
\text { Indicative Target }\end{array}$ & $\begin{array}{c}\text { End-Dec } \\
\text { Performance/Assessment } \\
\text { Criteria }\end{array}$ & $\begin{array}{l}\text { End-March } \\
\text { Indicative } \\
\text { Target }\end{array}$ & $\begin{array}{l}\text { End-June } \\
\text { Assessment } \\
\text { Criteria }\end{array}$ & $\begin{array}{l}\text { End-Sept } \\
\text { Indicative } \\
\text { Target }\end{array}$ & $\begin{array}{l}\text { End-Dec } \\
\text { Assessment } \\
\text { Criteria }\end{array}$ \\
\hline & & Prog. Adj. Prog. & Adj. Proq. Prel. Est. & & Prog. & Prog. & Prog. \\
\hline
\end{tabular}

\section{Assessment/Performance Criteria for end-June/December}

Net credit to the government (cumulative ceiling)

Stock of reserve money (ceiling) 2/

Stock of net international reserves of the BM (floor, US\$ millions)

New nonconcessional external debt contracted or guaranteed by the central government or the BM or selected state-owned enterprises with maturity of

one year or more (ceiling, US\$ millions)

Stock of short-term external public debt outstanding (ceiling)

External payments arrears (ceiling)

\section{Indicative targets:}

Government revenue (cumulative floor)

$\begin{array}{rrrrrrrrrr}2,148 & 2,435 & 978 & 2,148 & 2,494 & 790 & -124 & -1,743 & 868 & 933 \\ 19,762 & 20,512 & 21,102 & 22,685 & 23,685 & 24,464 & 21,031 & 24,567 & 25,753 & 28,173 \\ 1,487 & 1,484 & 1,851 & 1,758 & 1,725 & 1,834 & 1,711 & 1,759 & 1,885 & 1,930 \\ & & & & & & & & & \\ 5 & 5 & 5 & 5 & 5 & 5 & 5 & 200 & 200 & 200 \\ 0 & 0 & 0 & 0 & 0 & 0 & 0 & 0 & 0 & 0 \\ 0 & 0 & 0 & 0 & 0 & 0 & 0 & 0 & 0 & 0 \\ 30,624 & 30,624 & 32,859 & 42,553 & 42,553 & 46,733 & 10,810 & 27,049 & 41,732 & 56,474 \\ \ldots & \ldots & \ldots & \ldots & \ldots & \ldots & \ldots & \ldots & 43,562 & 58,424\end{array}$

Priority spending (cumulative floor)

$\begin{array}{llllll} & \ldots & \ldots & \ldots & \ldots & \ldots\end{array}$

43,562

58,424

Sources: Mozambican authorities and IMF staff estimates

For definition and adjustors see the attached Program Monitoring Section of the Memorandum of Economic and Financial Polices and the Technical Memorandum of Understanding.

${ }^{2}$ From June 2010, this is calculated as average of daily values during the third month of the quarter. 
Table 9 . Mozambique: Structural Conditionality under the current PSI/ESF, 2010

\begin{tabular}{|c|c|c|}
\hline Actions & Status & $\begin{array}{l}\text { Expected Date of } \\
\text { Implementation }\end{array}$ \\
\hline 1. Approval by the Minister of Finance of the e-Tributação (e-tax) Strategic Planning Document & Met & May 15,2010 \\
\hline $\begin{array}{l}\text { 2. Strengthening the Revenue Authority (Administração Tributária , AT): enhancing the management IT } \\
\text { system and approving the new organic structure. } \\
\text { (i) enhancement of the management information system; } \\
\text { (ii) submission to the Council of Ministers of two decrees to approve the new organic structure and } \\
\text { remuneration status AT's staff; and } \\
\text { (iii) approval of a resolution by the Interministerial Committee of Civil Service of a resolution that } \\
\text { approves the AT's new career structure. }\end{array}$ & $\begin{array}{l}\text { On track; measure (i) and } \\
\text { (ii) are completed, and } \\
\text { measure (iii) is expected } \\
\text { by the target date. }\end{array}$ & May 31, 2010 \\
\hline 3. Creation of an EITI Secretariat & Met & March 31, 2010 \\
\hline 4. Adoption of a financial sector contingency plan & In progress & May 31, 2010 \\
\hline
\end{tabular}




\section{APPENDIX I}

\section{REPUBLIC OF MOZAMBIQUE: LETTER OF INTENT}

May 24, 2010

Mr. Dominique Strauss-Kahn

Managing Director

International Monetary Fund

Washington, D.C. 20431

U.S.A.

Dear Mr. Strauss-Kahn:

The Government of Mozambique requests the completion of the sixth review under the Policy Support Instrument (PSI) and the second review under the Exogenous Shocks Facility (ESF). It also requests the approval of a successor PSI for 2010-13. In support of this request, we are transmitting the attached Memorandum of Economic and Financial Policies (MEFP), which reviews implementation of our economic program under the current PSI and sets out the government's objectives and policies over the short and medium term under the new program.

These policies are consistent with the government's medium-term Plano de Acẫ para a Reduạo da Pobreza Absoluta II (PARPA II) for 2006-09, which was extended to 2010. It aims to maintain macroeconomic stability, promote diversified and strong economic growth, and reduce poverty. A successor Poverty Reduction Strategy is expected to be approved in the second half of 2010, before the first review of the new PSI.

With respect to the current program, all quantitative assessment/performance criteria (A/PC) through end-December 2009 were met, except for the one on reserve money, for which we request a waiver. Reserve money exceeded the program ceiling because of the continued difficulty in predicting the demand for currency in circulation as a result of both the year-end seasonal surge and the structural shift from the expansion of banking services in the economy. We also made strong progress in implementing our structural reform program.

The government believes that the policies outlined in the MEFP are adequate to achieve the objectives of the successor PSI-supported program. Given our dedication to macroeconomic stability, we stand ready to take any additional measures necessary to achieve our policy objectives. The government will consult with the IMF — at its own initiative or whenever the Managing Director requests such a consultation - should revisions be contemplated regarding the policies contained in the attached MEFP. The government will provide the IMF with such information as the IMF may request to be able to assess the progress made in 
implementing the economic and financial policies and achieving the objectives of the program.

Sincerely yours,

/s/

Manuel Chang

Minister of Finance /s/

Ernesto Gouveia Gove

Governor

Bank of Mozambique

Attachments: $\quad$ Memorandum of Economic and Financial Policies

Technical Memorandum of Understanding 


\section{ATtachment I}

\section{Republic of MozambiQue: Memorandum of Economic and Financial Policies}

May 24, 2010

\section{Performance Under the PSI ANd ESF ARRANGement}

1. Mozambique showed considerable resilience to the global economic crisis. Real GDP expanded by $6 \frac{1}{3}$ percent in 2009 , much stronger than expected. Economic activity benefited from dynamic construction, energy, and financial sectors. However, the global crisis triggered large declines in export receipts and private external borrowing. The impact on external reserves was mitigated by the SDR allocation and ESF resources, resulting in an import reserve coverage above 5 months. The government eased macroeconomic policies to contain spillover effects of the crisis to the domestic economy. An accommodating monetary policy facilitated the substitution of foreign borrowing with an exceptionally strong private sector credit expansion. A strong revenue performance kept the size of the automatic stabilizers small and resulted in a lower-than-expected domestic primary fiscal deficit.

2. All the quantitative performance/assessment criteria (P/AC) were met through endDecember 2009, except for the one on reserve money, for which we request a waiver. Base money exceeded the program ceiling because of the continued difficulty in predicting the demand for currency in circulation as a result of both the year-end seasonal surge and the structural shift arising from the expansion of banking services in the economy. Structural reforms are on track as well. Specifically, the Extractive Industry Transparency Initiative (EITI) secretariat was created at end-March 2010 and both benchmarks related to the Revenue Authority - the strengthening of its organizational structure and adoption of the $e$ tax Strategic Planning Document - are being implemented as planned. However, the financial sector contingency plan envisaged for end-May is likely going to be completed by end-September 2010, partly due to delays in the government's application for, and the World Bank's approval of, funding for the exercise.

\section{ObJectives ANd Policies Going Forward}

\section{A. Economic Objectives}

3. The government takes pride in Mozambique's strong economic performance and successful policy implementation under successive IMF-supported programs. This enabled the country to preserve its sound economic fundamentals, with strong economic growth, single-digit inflation, a relatively comfortable international reserves position, and low external and public debt indicators. As a result, the government has gained some flexibility to ease macroeconomic policies to respond to exogenous shocks - such as the recent global crisis - and, going forward, to step up its economic development efforts. 
4. Such efforts to sustainably raise and broaden the country's productive base are necessary, since Mozambique's economic growth, although high by regional standards, has been trending down over the last decade.

5. Going forward, the government's focus will be on policies to create an environment conducive to strong private sector activity, which is expected to also help ensure that more and more segments of the population will benefit from economic development. Specifically, the government considers the following avenues to be the most promising to help boost economic development: (i) maintaining macroeconomic stability; (ii) encouraging additional national and foreign direct investment in the natural resources export sector; (iii) significantly stepping up public investment in transport and electricity infrastructure, partly financed through nonconcessional external borrowing and/or Public-Private Partnerships (PPP); (iv) improving the business climate; and (v) reaping benefits from regional integration. In all these efforts, the government will closely cooperate with the domestic private sector and tap expertise from development partners.

6. Consistent with these objectives and policies, the government will update Mozambique's Five-Year Government Program (PQG) for 2010-14 and adopt it by mid2010. The development plan will be supplemented by an updated Poverty Reduction Strategy, which will be drafted involving the private sector, civil society, and development partners, and finalized in the second half of 2010, before the first review under the PSI.

\section{B. Macroeconomic Outlook}

7. As the global economic crisis wanes, the economic outlook is expected to become more favorable. Real GDP growth should accelerate to $6 \frac{1}{2}$ percent in 2010 and 73 aercent by 2013 , largely because of new megaprojects, stepped-up public investment in areas with an expected large growth dividend, and larger private sector participation. Continued prudent macroeconomic policies should keep inflation at around 6 percent on average over the medium term, with a temporary spike in 2010 to above 9 percent following the gradual removal of the fuel subsidy. The government's investment plans should not fundamentally burden the current account and reserve levels; the current account (after grants) and international reserves are expected to hover around 14 percent of GDP and above five months of imports, respectively, over the next three years.

\section{Macroeconomic Policy Mix}

8. In 2010, the government intends to gradually unwind the temporary monetary and fiscal stimulus which helped Mozambique weather the impact of the global economic crisis. In particular, the Bank of Mozambique (BM) will begin to reverse, in tandem with the expected recovery of global credit markets, the sharp easing of monetary policy that facilitated substitution of foreign borrowing with domestic credit in the wake of the crisis in 2009. This should also help ward off potential inflationary pressures arising from the 
recent exchange rate depreciation and from spillovers from the removal of the fuel subsidy, while sustaining credit quality. As to fiscal policy, the strength in revenue collections is expected to continue and should allow a full reversal of the automatic stabilizers and a moderate reduction in the primary domestic deficit relative to 2009.

9. Over the medium term, the government will adjust its macroeconomic policy mix to gradually and prudently increase public investment to close gaps in transport and electricity infrastructure and thus help raise the country's growth potential. To this end, the fiscal stance will be adjusted to make room for higher domestic and external borrowing, over a limited time horizon, to implement selected high-priority projects with an expected high economic return. Part of the external borrowing is expected to be on nonconcessional terms. Although this will worsen Mozambique's low debt indicators, the limited time horizon of the planned investment increase and our commitment to concentrate on investment projects with a high growth dividend should ensure that debt sustainability is not at risk.

10. The temporary time horizon of the surge in capital spending will be consistent with macroeconomic stability and debt sustainability. It is not expected to crowd out private investment nor create pressure on domestic demand, as labor markets are underutilized and the investments will have a high import component. In addition, the domestic primary fiscal deficit will remain moderate, and monetary policy will be appropriately tight to ward off inflationary pressures while supporting a continued financial deepening. Should domestic demand pressures materialize, the authorities stand ready to adjust macroeconomic policies accordingly.

\section{0 budget implementation}

\section{Fiscal Policy}

11. The government aims to reduce the domestic primary deficit by $1 / 4$ percentage point, to 4.2 percent of GDP, in 2010. This mainly reflects our intention to further improve tax administration and contain current expenditure. While the 2010 budget law anticipates strong efficiency gains in tax administration that could boost the revenue-to-GDP ratio by 0.7 percentage point, to $183 / 4$ per cent of GDP, the government will base its budget execution on more conservative assumptions. As a result, the government will take the following measures to keep domestic current spending broadly unchanged in terms of GDP relative to 2009 until evidence of a stronger revenue performance materializes:

- In accordance with legal provision of the 2010 Budget Law (Article vii), the Council of Ministers approved the decree on the provisions regarding budget execution (Delegaão de Competê ncia sobre a Execução do Orçamento ) on April 27, 2010. In addition, on May 18, 2010, the Minister of Finance issued the interministerial regulation (Circular Ministerial) providing the guidance for line ministries for budget execution and contingencies. This legal framework, which is consistent with the general Public Financial Management Law (SISTAFE 2002), limits budget execution to 
cautionary ceilings as long as revenue collections remain uncertain. According to those provisions, such ceilings are: (i) 90 percent for goods and services and other current expenditures; (ii) 85 percent for civil service wages and transfers; and (iii) 90 percent for domestically financed capital spending. As a result, spending in those categories is currently envisaged to be MT 6.7 billion (2.2 percent of GDP) below appropriations in the 2010 budget law. The decision to spend beyond those ceilings will be taken by midNovember.

12. The government has initiated the phasing out of the fuel subsidy and aims to gradually restore market-based retail prices by the third quarter of 2010 . The date of the full pass-through will depend on international price movements but will ultimately entail the unconstrained application of the existing monthly price adjustment formula. To ensure transparency, the government will explicitly show fuel subsidies in its budget documents. With a view to protecting vulnerable segments of the population, the government considers replacing the fuel subsidies with better targeted and more effective alternative measures benefiting those truly in need, in consultation with development partners.

\section{Medium-term fiscal stance}

13. The government aims to step up its investment in transport and electricity infrastructure while safeguarding macroeconomic stability. To this end, the medium-term fiscal stance envisages enhanced borrowing from domestic and external sources over a limited time horizon of five years, which would lead to a concomitant temporary rise in the overall fiscal deficit (after grants). During the same period, the government commits to preserve the domestic primary deficit at around 4 percent of GDP. This entails that the expected efficiency gains in revenue administration of 2 percent of GDP will be channeled toward enhancing domestic spending priorities, without any additional recourse to financing.

\section{Stepping up investment}

14. The focus of the central government's investment strategy will be in transport and electricity infrastructure. This is to ensure that the expected growth effect materializes and the scaling up is consistent with the macroeconomic framework. Priority will be given to projects that could have a catalytic effect on private investment. Any new contracting of nonconcessional external borrowing or guarantees by the Central Government and selected state-owned entities (SOEs) subject to the related continuous quantitative AC (see below) will be in those sectors (continuous structural benchmark). The government is currently assessing the prioritization and sequencing of infrastructure investment projects and expects to complete this process by the time of the first program review. It expects that several of the key projects will enjoy financing and/or co-financing from development partners, while others could be developed under a concession or a Public-Private Partnership (PPP). For any projects chosen to be financed with nonconcessional resources, the government will share all project feasibility studies — including those from donors co-financing possible projects - with 
Bank and Fund staff. Among the projects under evaluation by the government, the following specific projects enjoy the highest priority at present:

- $\quad$ The international airport of Nacala in Nampula province, which would play a pivotal role in developing the northern part of the country and in servicing a special economic zone;

- The rehabilitation of the port of Beira, which is strategically located between the northern and southern parts of the country and also serves Malawi and Zimbabwe, the landlocked neighboring countries;

- An expansion of electricity production at the Cahora-Bassa dam in central Mozambique, which should enhance the reliability of the supply of electricity;

- The construction of a power line between the Cahora-Bassa dam and Maputo, which would reduce the dependency on electricity re-imports; and

- An expansion and/or rehabilitation of the road network, as currently only about onethird of Mozambique's road infrastructure is asphalted. Possible priority projects could include the completion of the transit corridor connecting the port of Beira with Zimbabwe, with the rehabilitation of the remaining section from Beira to Inchope $(120 \mathrm{~km})$; and the road between the provinces of Gaza and Maputo $(170 \mathrm{~km})$, which would connect areas with high potential for tourism and agriculture.

\section{Borrowing strategy}

15. The government aims to implement its stepped-up investment plans by tapping domestic and international financing. As a general principle, the government will aim to rely on the creation of fiscal space through a strengthening of revenue collections, grants, and concessional borrowing first before increasing domestic and external financing:

- $\quad$ Domestic Financing. The government will limit its annual recourse to domestic financing to less than 1 percent of GDP over the medium term. This is expected to avoid crowding out the private sector. For 2010, the ceiling on net credit to the government is set at MT -1743 million for end-June (indicating a net accumulation in deposits) and MT 933 million for end-December (quantitative AC); these levels largely reflect a drawdown of deposits related to the advance disbursement of World Bank budget support in late 2009. The government and the BM will enhance their coordination on cash flow management, so as to facilitate the BM's liquidity forecasting and monetary operations.

- External financing. Concessional donor funds will remain the prime sources of financing in the foreseeable future. Nonetheless, given the size of the planned investment push, the government intends to contract nonconcessional external borrowing of no more than US\$900 million during the three-year program period, 
averaging about $2^{1 / 2}$ percent of GDP per year. An annual borrowing profile for the program period will be defined by the time of the first program review when the planning of size, purpose and timing of our investment plans will have been firmed up. At this stage, the contracting or guaranteeing of nonconcessional external loans by the central government and key state-owned entities, including the Road Fund, for the investment projects in the infrastructure and energy sectors defined in the previous section will be limited to US\$200 million for 2010 (continuous quantitative AC).

16. By end-November 2010, the government will finalize a comprehensive multi-year debt strategy. The preparation of the debt strategy will be supported by FSTAP technical support and closely coordinated with Bank and Fund staff, including during the drafting stage. Key elements of the strategy are expected to include steps to derive an annual borrowing profile and calendar, lengthen the maturity structure to help extend the domestic yield curve, develop the institutional framework of domestic financial markets, and identify possible external financing options (structural benchmark).

17. In the same vein, the government will continue to strengthen its debt management. The debt unit in the Ministry of Finance will benefit from the addition of qualified staff to facilitate the semi-annual production of a debt sustainability analysis (DSA); the first such analysis will be completed and published by end-September 2010 (structural benchmark). The addition of necessary technical expertise aims to help the government make informed decisions about borrowing options (such as choice of instruments, size, currency, and maturity) and the evaluation of possible risks (such as rollover, currency and interest rate risk). The debt unit will also benefit from technical advice from the IMF and World Bank and the creation of a debt management committee (DMC), which will provide technical and analytical support for the development of the macroeconomic framework and DSA; the DMC will comprise staff of the Ministries of Finance, Planning and Development, the BM, and other relevant institutions, as needed.

\section{Priority social spending}

18. The government recognizes the importance to protect priority social spending to help sustain progress toward meeting the MDGs, including especially with respect to reducing poverty. Such spending is defined consistently with the PARPA classification. Such spending averaged 17.3 percent of GDP during 2007-09, representing 62 percent of total expenditure. It will be raised to 19.1 percent of GDP in 2010, equivalent to about 62.3 percent of total spending. An indicative floor of such spending is incorporated in the program. The definition of priority spending will be aligned with the any revisions to the concept under the new FiveYear Government Program ( $P Q G)$ and the successor poverty reduction strategy once they are finalized. 


\section{E. Fiscal Structural Reforms}

\section{Expanding budget coverage}

19. While at present the fiscal stance is measured on a central government basis, the government will expeditiously work toward integrating the Road Fund, the water authority (FIPAG), and the electricity company (EDM) into the fiscal and debt analysis. To this end, by end-June 2010, the government, with technical advice by Fund staff, will develop a fiscal template that will consolidate the revenue, expenditure, and financing of the central government and those entities, in consultation with Fund staff. On this basis, the government will produce by end-August 2010 quarterly consolidated fiscal accounts beginning in 2008 . The Law on Public Enterprises, as mentioned above, will further stipulate the reporting requirements of SOEs to the government. This will form a basis for further broadening budget coverage over time, which we will undertake supported by Fund technical advice.

\section{Revenue effort}

20. The government will strive to raise its revenue-to-GDP ratio by 1.5 percentage points during the program period. A quantitative indicative target will help monitor progress in this regard. Technical assistance has helped focus the reforms in the areas of tax administration and tax policy on the following key initiatives:

- $\quad$ Rolling out the electronic tax system e-Tributação (e-tax): Following the approval of the e-Tributaço Strategic Planning document on May 15, 2010, the government will approve in 2010 a procedure manual on the collection of the corporate income tax as a pilot for the e-tax roll-out. The revenue authority has also defined a set of concrete actions aimed at strengthening tax collection and improving the business environment. This includes the introduction of online tax filing and the possibility to pay taxes via bank transfer.

- $\quad$ Reinforcing large taxpayers unit (LTU): The national coordination unit for large tax payers, responsible for planning and monitoring all large taxpayers in the country including megaprojects, will initiate its operations by end-June 2010.

- Tax policy: To create a level playing field and improve the business environment, the government will assess the recommendations of the recent Fund technical assistance mission by the time of the first program review. As a first step, the government will create the legal basis for the tax treatment of new financial instruments, including mutual funds, leasing, and securitized loans.

\section{Wage policy}

21. The government will continue implementing a reform of the civil service pay scale. It approved a new salary policy in September 2008 that it will phase in over the medium term in a very gradual manner, in line with the need to preserve macroeconomic stability and fiscal sustainability. This gradual approach will stabilize the wage bill below $9 \frac{1}{4}$ percent of 
GDP over the medium term. The new policy aims to simplify and rationalize the salary scales across ministries, decompress the scales consistent with qualification and responsibility, reform the system of housing and other allowances, and harmonize the salary policy with the pension system. Further technical work, supported by development partners, will be undertaken in 2010 to help determine specific elements and the sequencing of reform steps.

\section{Strengthening public financial management (PFM)}

22. Based on the PFM vision paper and the 2010-12 SISTAFE Action Plan and Budget, the government envisages the following key measures in the short run:

- $\quad$ Continued implementation of SISTAFE system: e-SISTAFE will be further rolled out to 15 districts and 35 institutions. Budget execution through e-SISTAFE will gradually increase to 37.5 percent of the executed budget by end-2010. Its program classifiers will be further developed consistent with sectoral accounting, planning and reporting needs.

- $\quad$ Rolling out e-FOLHA: In order to increase coverage of the e-SISTAFE, by endSeptember 2010 the salary calculation and processing functionality will be rolled out to 8 sectors at the central level and to the City and Province of Maputo for a gradual introduction of direct salary payments into bank accounts.

- Improved integration of internal audit in e-SISTAFE system: The General Inspectorate of Finance (IGF) will move toward risk-based audits in light of the gradual roll-out of e-SISTAFE. To this end, IGF will issue a circular to financial departments of line ministries by September 2010 specifying that internal audit will be based on electronic e-SISTAFE reports wherever the system is used. In addition, to reflect emerging fiscal risks from the stepping up of infrastructure investments, IGF will reinforce its work program on state owned enterprises and PPPs.

- Improving aid management: The MF will actively encourage donors to use the singleand multi-currency treasury accounts at the BM for disbursing project aid.

- $\quad$ Reinforcing investment planning, limiting fiscal and quasi-fiscal risks, and maximizing economic benefits: By end-September 2010, the Council of Ministers will adopt a PPP Law, which will also be applicable to mega projects and other concessions, including those in the power generation area (structural benchmark). The law will include the creation of the PPP unit within the Ministry of Finance and the mechanisms to formalize the PPP approval process. It will also introduce 'gateway' decision points where the consensus of the Ministry of Finance would be required before the PPP can proceed, so as to manage risks. Implementation of the new framework will be facilitated by the creation of the new PPP unit in the Ministry of Finance to support the gateway process and improve financial oversight of PPPs, including through mandated regular reporting from PPPs on their financial statements to the PPP unit. The unit should be operational by end- 2010 . 
- Improving the framework for public enterprises: A Public Enterprises Law will be adopted by the Council of Ministers by end-July 2010. Among other things, it will ringfence commercial activities of state-owned entities and require quarterly financial reporting to the Ministry of Finance and an annual tabulation of financial and other assets to the General State Accounts. It will also reaffirm the existing provisions that have limited contingent liabilities emanating from state-owned entities, including the need to obtain approval by the Minister of Finance for all borrowing.

- $\quad$ Enhancing procurement systems: Following up on the Country Procurement Assessment Report (CPAR), the government will adopt terms of reference for carrying out procurement audits in order to assess the integrity and transparency of the system. The ministries that are to be audited in 2011 will be selected by December 2010. By end-June 2010, a strategy for training and capacity development will be defined, and by end-December 2010, the terms of reference for the development of a career in government procurement and certification of experts in this area will be formulated.

\section{Reforming the National Institute for Social Security (INSS)}

23. To limit fiscal risks and improve governance and transparency, the government is reassessing its approach to reform the INSS. The adoption of a new investment strategy has been delayed, pending further necessary conceptual work supported by World Bank technical assistance. The new investment strategy will aim solely at protecting the interest of the beneficiaries of the social security system and be approved by end-June 2010. The INSS will also: (i) publish its audited financial statements of 2008 by end-August 2010 and of 2009 by end-2010; (ii) assess its financial viability based on an updated actuarial study that takes into account the financial statements through 2007, and by-end 2010 initiate corrective actions to guarantee the financial equilibrium of the INSS, to be implemented by INSS or to be submitted to the Council of Ministers; (iii) adopt its new organizational structure by endOctober 2010; and (iv) introduce an IT system during 2010 to help improve registration of contributors and claimants and strengthen collection of contributions.

\section{Enhancing governance in the natural resources sector}

24. The government is committed to becoming a full member of EITI within the envisaged timeframe of two years, i.e., by May 2011. This will enhance the contribution of the natural resource sector to economic development as a result of the improved transparency and accountability in the sector. The newly created EITI secretariat will launch a dedicated EITI website by end July 2010, produce and distribute relevant brochures on EITI by endJuly 2010, elaborate the terms of reference for the EITI auditor by end September 2010, and appoint the qualified EITI auditor by end November 2010. 


\section{F. Monetary and Exchange Rate Policies}

25. The BM is committed to prudent monetary and exchange rate policies aimed at containing inflation at around 6 percent on average over the medium term. The monetary expansion consistent with this objective is expected to leave room for private sector credit expansion.

26. In its monetary policy implementation, the BM will continue to pay close attention to the real effective exchange rate vis-àvis a br oad basket of currencies. This should allow the exchange rate to adjust freely to evolving patterns of trade and financial flows while safeguarding Mozambique's international reserves. The BM will continue to be cautious in managing the country's reserves in light of increasing external obligations.

27. The BM will decide whether to move to an inflation targeting framework over the next two years. Supported by IMF technical assistance, the BM is working on establishing the prerequisites for a successful transition, as outlined in the relevant action plan.

Specifically, the BM will: (i) assess which inflation rate should be targeted and what core inflation rate should be used to assess inflationary conditions; (ii) enhance its monitoring, understanding, and capacity to project the monetary transmission mechanism; (iii) adopt and implement new monetary instruments to steer monetary conditions effectively; and (iv) improve its communications strategy with the public.

28. During the interim period, the BM will continue its reserve money targeting. A particular challenge will continue to be the structural shifts and seasonal surges in the demand for currency. To this end, the BM will:

- $\quad$ Improve reserve money targeting. Such targeting will be based on monthly averages, which will neutralize the spike in cash during the last two weeks of each month; and

- $\quad$ Further enhance liquidity and foreign exchange management. The BM will enhance coordination with the Ministry of Finance on domestic and external borrowing plans, aid management, and cash flow projections, as well as with banks on their liquidity requirements, as the potentially significant increase in foreign exchange inflows from the government's borrowing plans is likely to accentuate the BM's liquidity and foreign exchange management challenges.

29. The government intends to accept the obligations under Article VIII sections 2, 3, and 4 of the Fund's Articles of Agreement in due course. The official communication will be sent as soon as the implementation regulation has been brought in line with the new legislative framework that came into effect on March 11, 2009. 


\section{G. Financial Sector Policies}

30. The government and the BM will ensure expeditious follow-up to the recommendations of the 2009 Financial Sector Assessment Program (FSAP) update and recent technical assistance:

- Developing Financial Sector Action Plan. After some delay, the interagency task force will promptly finalize an action plan to implement the FSAP recommendations by endJuly 2010. The plan will include measures to enhance access to finance and financial market development, strengthen compliance of the supervisory framework with Basel Core Principles, and complete the modernization of the payments system.

- $\quad$ Stepping up risk management: In line with FSAP recommendations, the BM will issue regulation (Aviso) on risk management by end-December 2010. The government is working on a draft decree on deposit insurance which it intends to issue by year-end.

- Enhancing supervision of banking system. Following the rapid credit growth over the last two years, the BM will closely supervise activities in the banking system and encourage banks to develop a stress testing framework. Close attention will be devoted to assessing liquidity conditions and the quality of loan portfolios.

- $\quad$ Fighting money laundering and financial crime: Following the Inter-Ministerial Civil Service Committee's approval in April 2010 to hire new staff, the Gabinete de

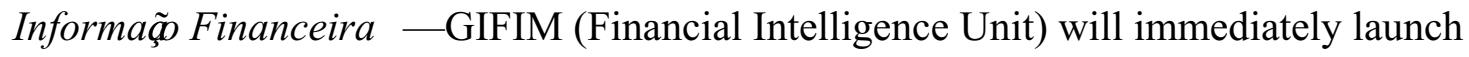
the recruitment process and proceed with the necessary capacity building, supported by development partners. The draft amendment to the 2002 AML law, which will remove incompatibilities between the law establishing the GIFIM and the AML law, will be submitted to Parliament by end-August 2010.

\section{H. Other Structural Policies}

31. The government is intensifying its reforms to improve the business environment to help raise Mozambique's growth potential, diversify exports, and stimulate new investment. In coordination with the World Bank, it will work toward implementing a range of fast-track measures by end-2010. This is expected to ease red tape, streamline the granting of businessrelated licenses, improve bankruptcy proceedings, and facilitate trading across borders.

32. The Government aims to improve its statistical data compilation and dissemination. This should facilitate migration to the Special Data Dissemination System (SDDS) in due course. The Government will focus on improving data quality related to the quarterly national accounts, consumer prices index, government finance statistics, and megaprojects, consistent with IMF technical assistance advice. In particular, the INE will choose a new calculating software before the new rebased Maputo CPI is launched in 2011; this will 
remove the possible bias of the CPI. INE also intends to increase the geographic coverage of the CPI by including the Greater Maputo area and the populous province of Zambezia.

\section{Program Monitoring}

33. The quantitative AC for end-June 2010 and end-December 2010 and indicative targets for the second half of 2010 are shown in Table 1. Table 2 lists the structural benchmarks for the new PSI. The first PSI review is expected to be completed by endDecember 2010 and the second PSI review by end-June 2011. 
Table 1. Mozambique: Quantitative Assessment and Performance Criteria and Indicative Targets $1 /$ (Millions of meticais, unless otherwise specified)

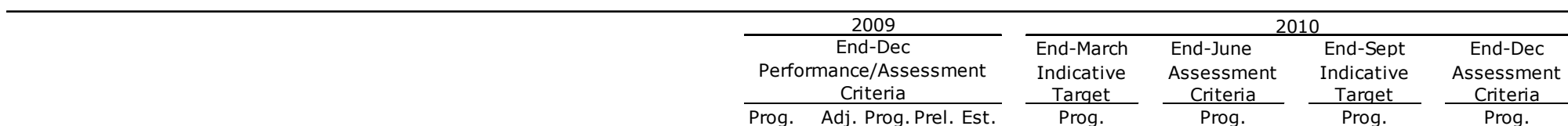

\section{Assessment/Performance Criteria for end-June/December}

Net credit to the government (cumulative ceiling) 2/

Stock of reserve money (ceiling)

Stock of net international reserves of the BM (floor, US\$ millions)

New nonconcessional external debt contracted or guaranteed by the central

government or the BM or selected state-owned enterprises with maturity of

one year or more (ceiling, US\$ millions)

Stock of short-term external public debt outstanding (ceiling)

External payments arrears (ceiling)

Indicative targets:

Priority spending (cumulative floor)

\begin{tabular}{rrrrrrr}
2,148 & 2,494 & 790 & -124 & $-1,743$ & 868 & 933 \\
22,685 & 23,685 & 24,464 & 21,031 & 24,567 & 25,753 & 28,173 \\
1,758 & 1,725 & 1,834 & 1,711 & 1,759 & 1,885 & 1,930 \\
& & & & & & \\
5 & 5 & 5 & 5 & 200 & 200 & 200 \\
0 & 0 & 0 & 0 & 0 & 0 & 0 \\
0 & 0 & 0 & 0 & 0 & 0 & 0 \\
42,553 & 42,553 & 46,733 & 10,810 & 27,049 & 41,732 & 56,474 \\
$\ldots$ & $\ldots$ & $\ldots$ & $\ldots$ & $\ldots$ & 43,562 & 58,424 \\
\hline
\end{tabular}

933

Sources: Mozambican authorities and IMF staff estimates

' For definition and adjustors see the attached Program Monitoring Section of the Memorandum of Economic and Financial Polices and the Technical Memorandum of Understanding.

${ }^{2}$ From June 2010, this is average of the daily stock of reserve money and FDP in the third month of the quarter. 


\section{Table 2. Mozambique: Structural Benchmarks for Successor PSI}

Mozambique: Structural Benchmarks for Successor PSI

\begin{tabular}{|c|c|}
\hline Actions & $\begin{array}{l}\text { Expected Date of } \\
\text { Implementation }\end{array}$ \\
\hline $\begin{array}{l}\text { Any new contracting of nonconcessional external borrowing } \\
\text { or guarantees by the Central Government and selected state- } \\
\text { owned entities (SOEs) subject to the related continuous } \\
\text { quantitative AC will be for transportation and electricity } \\
\text { infrastructure investment, as described in paragraph } 14 \text { of } \\
\text { the MEFP. }\end{array}$ & Continuous \\
\hline $\begin{array}{l}\text { Adoption by Council of Ministers of PPP, Concessions and } \\
\text { Megaprojects Law, as described in paragraph } 22 \text { of the } \\
\text { MEFP. }\end{array}$ & End-September 2010 \\
\hline $\begin{array}{l}\text { Finalization of a comprehensive debt strategy that will } \\
\text { assess the risk profile and the fiscal and macroeconomic } \\
\text { implications of new borrowing, as described in paragraph } 16 \\
\text { of the MEFP. }\end{array}$ & End-November 2010 \\
\hline $\begin{array}{l}\text { Completion of first Government Debt Sustainability Analysis, } \\
\text { as described in paragraph } 17 \text { of the MEFP. }\end{array}$ & End-September 2010 \\
\hline
\end{tabular}




\section{ATTACHMENT II}

\section{Republic of MozambiQue: Technical Memorandum of Understanding}

May 24, 2010

1. This Technical Memorandum of Understanding (TMU) defines the quantitative assessment criteria, indicative targets, and structural benchmarks on the basis of which the implementation of the Fund-supported program under the Policy Support Instrument (PSI) will be monitored. In addition, the TMU establishes the terms and timeframe for transmitting the data that will enable Fund staff to monitor program implementation.

\section{DEFINITIONS}

\section{Net credit to the central government}

2. Net credit to the central government (NCG) by the banking system is defined as the difference between the outstanding amount of bank credits to the central government and the central government's deposits with the banking system, excluding deposits in project accounts with the banking system, recapitalization bonds issued to the BM, and proceeds from the signing fee for mineral resource exploration. Credits comprise bank loans, advances to the central government and holdings of central government securities and promissory notes. NCG will be calculated based on data from balance sheets of the monetary authority and commercial banks as per the monetary survey. The limits on the change in NCG by the banking system will be cumulative from end-December of the previous year.

3. The central government encompasses all institutions whose revenue and expenditure are included in the state budget (Oramento do Estado) : central government ministries, agencies, and the administration of 11 provinces. Although local governments (33 municipalities or autarquias) are not included in the definition because they are independent, the bulk of their revenue is registered in the state budget as transfers to local governments.

\section{Government revenue and financing}

4. Revenue is defined to include all receipts of the General Directorate of Tax (Direcção Geral dos Impostos, DGI), the General Directorate of Customs (Direç̧̃o Geral das Alfândegas, DGA), and nontax revenue, including certain own-generated revenues of districts and some line ministries, as defined in the budget. Net receipts from privatization received by the National Directorate of State Assets (Direcção Nacional do Património do Estado) and unrealized profits transferred by the central bank to the treasury will not be considered as revenue (above the line) and will be accounted for as other domestic financing (below the line). 
5. For the purpose of program monitoring, revenue is considered as collected at the time when it is received by the relevant government collecting agencies, in cash or checks, or through transfers into the respective bank account.

\section{Priority social spending}

6. Priority social spending is based on the PARPA program categories. Accordingly, it will include total spending in the following sectors: (i) education; (ii) health; (iii) HIV/AIDS; (iv) infrastructure development; (v) agriculture; (vi) rural development; and (vii) governance and judicial system.

\section{Reserve money}

7. For the purposes of program monitoring reserve money is defined as the sum of currency issued by the BM and commercial banks' holdings at the BM. The target is defined in terms of the average of the daily end-of-day stocks in the month of the test date. The reserve money stock will be monitored and reported by the BM.

\section{Net international reserves}

8. Net international reserves (NIR) of the BM are defined as reserve assets minus reserve liabilities. The BM's reserve assets include (a) monetary gold; (b) holdings of SDRs; (c) reserve position at the IMF; (d) holdings of foreign exchange; and (e) claims on nonresidents, such as deposits abroad (excluding the central government's savings accounts related to mineral resource extraction concessions). Reserve assets exclude assets pledged or otherwise encumbered, including but not limited to assets used as collateral or guarantee for a third-party external liability (assets not readily available). The BM's reserve liabilities include: (a) all short-term foreign exchange liabilities to nonresidents with original maturity of up to and including one year; and (b) all liabilities to the IMF.

\section{New nonconcessional external debt contracted or guaranteed by the central government, the BM, and selected state-owned enterprises, with maturity of more than one year}

9. The ceiling on nonconcessional external debt applies to external debt contracted or guaranteed by the central government, the BM, the Road Fund, the water authorities (FIPAG), and the electricity company (EDM). It also applies to debt contracted by these three state-owned enterprises from domestic banks or from other state-owned enterprises that is contractually inter-related to external nonconcessional loans.

10. The ceiling applies to external debt with original maturity of one year or more and with a grant element below 35 percent. The grant element is calculated using currencyspecific discount rates based on the Organization for Economic Cooperation and Development (OECD) commercial interest reference rates in accordance with the annual 
Budget Law. The term 'debt' will have the meaning set forth in Point 9 of the Guidelines on Performance Criteria with Respect to External Debt in Fund Arrangements adopted on August 3, 1979, as amended August 31, 2009, effective December 1, 2009. The concept of external debt is defined on the basis of the residency of the creditor. The ceiling also applies to commitments contracted or guaranteed for which value has not been received. This assessment criterion will be assessed on a continuous basis.

\section{Stock of short-term external public debt outstanding}

11. The central government will not contract or guarantee external debt with original maturity of less than one year. This assessment criterion applies not only to debt as defined in Point 9 of the Guidelines on Performance Criteria with Respect to External Debt in Fund Arrangements adopted on August 3, 1979, as amended August 31, 2009, effective December 1, 2009, but also to commitments contracted or guaranteed for which value has not been received. Excluded from this assessment criterion are short-term, import-related trade credits. This assessment criterion will be assessed on a continuous basis.

\section{External payments arrears}

12. The government undertakes not to incur payments arrears on external debt owed or guaranteed by the central government, with the exception of external payments arrears arising from government debt that is being renegotiated with creditors. This assessment criterion will be assessed on a continuous basis.

\section{Foreign program assistance}

13. Foreign program assistance is defined as grants and loans received by the Ministry of Finance through BM accounts excluding those related to projects (Table 1).

\section{Actual external debt service payments}

14. Actual external debt service payments are defined as cash payments on external debt service obligations of the government and central bank, including obligations to Paris Club and other bilateral creditors rescheduled under enhanced HIPC Initiative completion point terms, multilateral creditors, and private creditors, but excluding obligations to the IMF (Table 1).

\section{ADJUSTERS}

\section{Net international reserves}

15. The quantitative targets (floors) for net international reserves (NIR) will be adjusted:

- downward by the shortfall in external program aid less debt service payments (up to US\$100 million), compared to the program baseline (Table 1); 
- downward/upward for any revision made to the end-year figures corresponding to the previous year; and

- downward to accommodate higher external outlays because of natural disasters, up to US\$20 million.

\section{Net credit to central government}

16. The quantitative targets (ceilings) for net credit to the central government (NCG) will be adjusted:

- upward by the shortfall in the MT value of external program aid receipts less debt service payments (up to the MT equivalent of US $\$ 100$ million at exchange rates prevailing at the respective test dates), compared to the program baseline (Table 1);

- downward by privatization proceeds in excess of those envisaged in the program, unless these proceeds are deposited in the government's savings accounts abroad;

- downward (upward) for any increase (decrease) in domestic financing from the nonfinancial private sector; and

- upward to accommodate the higher locally-financed outlays because of natural disasters, up to the MT equivalent of US\$20 million at exchange rates prevailing at the respective test dates.

\section{Reserve money}

17. The quantitative target (ceiling) for reserve money will be adjusted upward by the excess of the stock of currency in circulation above the level envisaged in the program. The target is defined in terms of the average of the daily end-of-day stocks in the month of the test date. The target will be adjusted up to MT 500 million for end-March, end-June, and end-September and up to MT 750 million for end-December (Table 1).

\section{DATA AND OTHER REPORTING}

18. The government will provide Fund staff with:

- monthly and quarterly data needed to monitor program implementation in relation to the program's quantitative targets and broader economic developments;

- $\quad$ weekly updates of the daily data set out in Table 1;

- weekly data set out in Table 4 of the TMU dated May 26, 2005;

- monthly updates of the foreign exchange cash flow of the BM;

- monthly data on government revenues (in detail according to the fiscal table) with a lag not exceeding one month; 
- $\quad$ monthly information on the balance of government savings accounts abroad;

- $\quad$ monthly data on domestic arrears;

- monthly budget execution reports (that will also be published) with a time lag not exceeding 45 days; and

- monthly data on gross international reserves, with the composition by original currencies and converted to US dollars at the actual exchange rates.

19. The monetary survey made available by the BM will clearly identify donor-financed project deposits (with a breakdown between foreign and domestic currency) included in net credit to the government in both the central bank's and commercial banks' balance sheets.

20. The government will provide Fund staff with documentation concerning external loan agreements once these have been signed and become effective. 
TMU Table 1. Mozambique: Net Foreign Assistance, 2009-10

\begin{tabular}{|c|c|c|c|c|c|c|c|c|c|}
\hline & \multicolumn{4}{|c|}{2009} & \multicolumn{5}{|c|}{2010} \\
\hline & \multicolumn{2}{|c|}{ Q4 } & \multicolumn{2}{|c|}{ Year } & Q1 & Q2 & Q3 & Q4 & Year \\
\hline & Prog. & Act. & Prog. & Act. & \multicolumn{5}{|c|}{ Prog. } \\
\hline Net foreign program assistance (US\$ mn) & 127 & 128 & 446 & 421 & 71 & 181 & 27 & 145 & 424 \\
\hline Gross foreign program assistance & 144 & 140 & 501 & 468 & 86 & 203 & 42 & 165 & 496 \\
\hline Program grants & 34 & 30 & 361 & 327 & 86 & 176 & 42 & 55 & 359 \\
\hline Program loans & 110 & 110 & 140 & 140 & 0 & 27 & 0 & 110 & 137 \\
\hline External debt service & 17 & 12 & 56 & 46 & 15 & 22 & 15 & 20 & 71 \\
\hline World Bank PRSC 6 Disbursement & 110 & 110 & 110 & 110 & 0 & 0 & 0 & 0 & 0 \\
\hline Net foreign program assistance (MT mn) & 2,885 & 3,743 & 11,331 & 11,777 & 1,991 & 5,378 & 829 & 4,582 & 12,781 \\
\hline Gross foreign program assistance & 3,895 & 4,062 & 13,270 & 12,923 & 2,406 & 6,021 & 1,278 & 5,218 & 14,923 \\
\hline Program grants & 928 & 1,067 & 9,500 & 9,125 & 2,406 & 5,229 & 1,278 & 1,741 & 10,655 \\
\hline Program loans & 2,967 & 2,996 & 3,770 & 3,798 & 0 & 792 & 0 & 3,476 & 4,268 \\
\hline External debt service & 1,010 & 320 & 1,939 & 1,147 & 415 & 643 & 449 & 636 & 2,142 \\
\hline World Bank PRSC 6 Disbursement & 2,697 & 2,769 & 2,697 & 2,769 & 0 & 0 & 0 & 0 & 0 \\
\hline Stock of outstanding currency (MTm) & 15,004 & 16,117 & 15,004 & 16,117 & 14,057 & 16,445 & 16,436 & 19,222 & 19,222 \\
\hline
\end{tabular}

Source: Mozambican authorities and IMF staff estimates 


\title{
INTERNATIONAL DEVELOPMENT ASSOCIATION AND INTERNATIONAL MONETARY FUND
}

\author{
REPUBLIC OF MOZAMBIQUE \\ Joint World Bank/IMF Debt Sustainability Analysis \\ Prepared by the staffs of the International Development Association and \\ the International Monetary Fund \\ Approved by Sudarshan Gooptu and Sudhir Shetty (World Bank) \\ and Roger Nord and Dominique Desruelle (IMF)
}

May 27, 2010

The joint IMF-World Bank low-income country debt sustainability analysis (LIC DSA) based on end-2009 debt stocks indicates that Mozambique's risk of debt distress remains low. As in the previous DSA, the external debt indicators remain well below their respective thresholds. However, the government's plans to temporarily increase public investment financed by external borrowing on nonconcessional terms, in line with the Fund's revised Debt Limits Policy, will noticeably increase debt vulnerabilities, as stress tests approach, and in some instances temporarily and marginally exceed, the relevant thresholds. This calls for a cautious approach with such borrowing and resolve to improve debt management capacity. As public debt is largely external, the evolution of public debt indicators largely mirrors that of external debt.

\section{BACKGROUND}

\section{External debt}

1. Mozambique's external public and publicly guaranteed (PPG) debt stock at end2009 was US\$3.45 billion in nominal terms or US\$1.59 billion in PV terms (Table 1). Of this, 67 percent was owed to multilateral creditors, 33 percent to bilateral creditors, while outstanding obligations to commercial creditors were negligible. The debt stock includes about US $\$ 0.7$ billion in obligations to non-Paris Club creditors that at end-2009 had not yet granted debt relief comparable to the HIPC Initiative.

2. The previous full DSA was conducted in late 2008 on the basis of end-2007 debt stocks. At that time, the PV of PPG debt was US\$0.84 billion, and the PV of debt at end2009 was projected to be US\$1.4 billion. The increase in the PV of PPG debt at end-2009 from the previous projection largely reflects in equal part the reduction in the discount rate from 5 to 4 percent and changes in the exchange rate. Borrowing in the interim was broadly 
as expected: disbursements were about 30 percent lower than projected for 2008 but were about 20 percent higher in 2009.

3. Private sector debt accounts for about two-fifths of Mozambique's total external debt, mainly because of borrowing to finance megaprojects. Particularly significant was borrowing of about US\$0.8 billion in 2007 related to the Cahora-Bassa hydroelectric power station.

Table 1. Mozambique: External and Domestic Nominal Debt Outstanding at end-2009

\begin{tabular}{|c|c|c|c|}
\hline & $\begin{array}{c}\text { Millions of US } \\
\text { dollars }\end{array}$ & $\begin{array}{c}\text { Percent of total } \\
\text { external debt }\end{array}$ & Percent of GDP \\
\hline Public and Publicly Guaranteed Debt & 3,745 & & 38.1 \\
\hline Domestic Debt ${ }^{1}$ & 294 & & 3.0 \\
\hline External Debt & 3,451 & 100.0 & 35.1 \\
\hline Multilateral Creditors & 2,307 & 66.8 & 23.5 \\
\hline IMF & 171 & 5.0 & 1.7 \\
\hline $\mathrm{IDA}^{2}$ & 1,339 & 38.8 & 13.6 \\
\hline African Development Bank ${ }^{3}$ & 385 & 11.2 & 3.9 \\
\hline Othe Multilaterals ${ }^{3}$ & 411 & 11.9 & 4.2 \\
\hline Bilateral Creditors ${ }^{3}$ & 1,144 & 33.2 & 11.6 \\
\hline Paris-Club ${ }^{4}$ & 74 & 2.1 & 0.8 \\
\hline Non-Paris Club ${ }^{5}$ & 1,070 & 31.0 & 10.9 \\
\hline Commercial Creditors & 0.0 & 0.0 & 0.0 \\
\hline Total Private and Non-Guaranteed External Debt & 2,605 & & 26.5 \\
\hline \multicolumn{4}{|l|}{ Memorandum Items } \\
\hline Total public and private external debt & 6,055 & & 61.6 \\
\hline PV of external Debt & 4,510 & & 45.9 \\
\hline PV of PPG external debt & 1,589 & & 16.2 \\
\hline PV of non-PPG external debt & 2,921 & & 29.7 \\
\hline Nominal GDP in US dollars & 9,831 & & \\
\hline
\end{tabular}

Sources: Mozambican authorities, and World Bank and IMF staff estimates.

${ }^{1}$ Central Government debt only, excluding deposits held at the banking sector.

${ }^{2}$ World Bank data.

${ }^{3}$ Mozambican authorities' data.

${ }^{4}$ Assumes implementation of debt relief.

${ }^{5}$ Only includes debt relief if concluded. Tables 2 and 4 include obligations assuming debt relief concluded by 2010. 


\section{Debt relief}

4. Mozambique in $\mathbf{2 0 0 1}$ benefited from assistance under the HIPC Initiative provided by multilateral and Paris Club bilateral creditors. ${ }^{1}$ Mozambique received further assistance in 2006 under the Multilateral Debt Relief Initiative (MDRI) from the African Development Fund (AfDF), the International Development Association (IDA) of the World Bank, and the IMF, according to which Mozambique's debt stock fell by US\$1.9 billion in nominal terms in $2006 .^{2}$

5. The authorities have continued working to conclude debt relief agreements with Paris Club creditors under the HIPC Initiative. Since issuance of the last full DSA, the Mozambican authorities have contacted Japan on the formalization and signing of the agreement on all pending debt cancellation. They reconfirmed that Japan is still in the process of coordinating domestic legal and financial issues among relevant ministries to that end. Mozambique has also reached an agreement in principle with Russia that remains to be concluded.

6. Mozambique has experienced delays in negotiating debt relief agreements with some of its non-Paris Club bilateral creditors. Negotiations are still ongoing with Angola, Bulgaria, India, Iraq, Libya, and Poland. The DSA projections assume that negotiations with non-Paris Club creditors will be concluded during 2010.

\section{Domestic debt}

7. The central government's domestic debt at end-2009 amounted to 3 percent of GDP. This debt is low by regional standards, reflecting the government's long-standing commitment to generally avoid domestic financing in an effort to provide sufficient room for private sector credit growth. Most of the government's domestic debt originates from bonds issued to strengthen the central bank's balance sheet during 2005-07 and to restructure commercial banks. It excludes the central bank's securities issued for monetary operations.

\section{Borrowing by state-owned enterprises}

8. The stock of external PPG debt incorporates external borrowing of the central government on-lent to state-owned enterprises (SOEs). The Ministry of Finance holds a veto on SOE's external borrowing. The central government's domestic debt at end-2009, however, does not include domestic obligations incurred by the SOEs, though these are relatively small. The financial positions of the key SOEs do not currently pose any

\footnotetext{
${ }^{1}$ See "Mozambique-HIPC Debt Initiative: President's Memorandum and Recommendation and Completion Point Document" (IDA/R99-139), and "Mozambique-Enhanced HIPC Debt Initiative: President's Memorandum and Recommendation and Completion Point Document”(IDA/R2001-0150).

2 The amount of MDRI relief provided by the AfDF was US\$464.5 million; IDA provided US\$1.3 billion; and the IMF provided US\$120.6 million.
} 
substantive threat to the central government's fiscal position and are not expected to pose a threat in the foreseeable future.

9. Since late $\mathbf{2 0 0 8}$, the government has concluded four-party framework agreements with Portugal for credit lines. These credit lines, totaling 700 million (about 10 percent of GDP), are to help finance infrastructure investment spending during 2010-15. ${ }^{3}$ Contractual partners are the governments of Mozambique and Portugal, the Portuguese savings bank (CGD), and a local bank (BCI). The agreement allows for the extension of external loans to BCI and on-lending of these funds to the road fund, a domestic public entity to finance road infrastructure. The terms for 400 million of the credit lines are concessional, but the terms on the remaining 300 million have a low grant element, as well as a relatively short maturity. ${ }^{4}$ The government has refrained from providing external guarantees, but has guaranteed repayments to the domestic bank. These loans are incorporated into the DSA as part of public external debt, although they do not trigger an assessment under IDA's Nonconcessional Borrowing Policy on technical grounds.

\section{UNDERLYING DSA ASSUMPTIONS}

\section{Macroeconomic assumptions}

10. The underlying macroeconomic assumptions (Box 1) are consistent with the medium-term macroeconomic framework under the Fund-supported program. Projected real GDP growth is below the 8 percent average over the past decade. During the period, growth was supported by large aid flows, as well as high private capital inflows, mainly to the natural resource sector, that together averaged about 20 percent of GDP. But growth has been trending down and requires an ambitious agenda of structural reforms and infrastructure investment to be sustained. The government is therefore aiming to temporarily raise public investment from an average of 11 percent of GDP during the past decade to about 15 percent of GDP over the medium term (or to 17 percent of GDP including the Portuguese credit lines). To continue sustaining growth, public investment will probably remain around 13 percent of GDP beyond the medium term. However, while private capital inflows are likely to be sustained, a tapering off of the significant donor assistance seems likely. The government will therefore need to rely more heavily on domestic resources and resort to external financing on commercial terms.

\section{The recently adopted Fund's new Debt Limits Policy makes room for such} nonconcessional financing. In November 2009, Mozambique was classified as a lower vulnerability/lower capacity country. Its CPIA and PEFA ratings, reflecting the significant PFM and other institutional reforms undertaken by the authorities in recent years, put it at the

\footnotetext{
${ }^{3}$ Lines of credit for 100 million, 400 million, and 200 million were signed in late 2008, late 2009 and early 2010, respectively.

${ }^{4}$ According to the OECD DAC's methodology for assessing concessionality.
} 
threshold of a classification as a high capacity country, although its debt management capacity was considered limited and prevented a higher classification. The authorities are receiving technical assistance from the World Bank through the Financial Sector Technical Assistance Project (FSTAP) to strengthen their debt management capacity. Under the new three-year economic program supported by the Fund's Policy Support Instrument, the authorities are committed to preserving macroeconomic stability, pursuing their reform agenda in public financial management, tax policy, and tax administration, and strengthening debt management. ${ }^{5}$ In view of these commitments, some untied limits on nonconcessional borrowing are envisaged during this period, consistent with the Fund's new Debt Limits Policy.

\section{Investment and growth}

\section{The impact of new borrowing to finance infrastructure investment on debt} sustainability hinges critically on its impact on growth. A range of studies generally finds a positive impact of public investment on growth, operating not only through a direct impact on economic activity, but also through spillover effects on private investment. In a multicountry study, Burnside and Collier (1997) found that a sustained increase in grant-financed investment by one percent of GDP raised real GDP growth in low-income countries with good policy implementation on a sustained basis by about 0.4 percentage points. ${ }^{6} \mathrm{~A}$ World Bank study focusing on Mozambique drew a comparable conclusion. ${ }^{7}$ It suggested that an increase in grant-financed investment by one percent of GDP increased growth by 0.25 percentage points. A cross-country Fund study largely confirms these estimates and, for Mozambique, concluded that a one percent of GDP increase in public infrastructure investment would raise output growth by 0.5 percentage points. ${ }^{8}$ How public investment is used also matters. For example, Aschauer (1989) found that investing in public infrastructure yields supernormal returns. ${ }^{9}$ Similarly, Easterly and Rebelo (1993) found that investment in transportation and communications is consistently correlated with growth. ${ }^{10}$ Hulton (1996), as

\footnotetext{
${ }^{5}$ Specific commitments include that the authorities complete their first own semiannual debt sustainability analysis by end-September 2010 and develop a multi-year debt strategy by end-November 2010. In these endeavors, they will benefit from Bank and Fund technical assistance; a Medium-Term Debt Strategy (MDTS) technical assistance mission is scheduled for June 2010.

${ }^{6}$ Burnside, Craig, and David Dollar, 1997. "Aid Spurs Growth in a Sound Policy Environment." Finance and Development, December 1997.

${ }^{7}$ Benito-Spinetto, Maria Teresa, and Peter G. Moll, 2005. "Macroeconomic Developments, Economic Growth and Consequences for Poverty." (Background paper for the Mozambique 2005 Country Economic Memorandum). February 2005.

${ }^{8}$ Vitek, Francis, forthcoming IMF Working Paper, 2010.

${ }^{9}$ Aschauer, D., “Is public expenditure productive?”. Journal of Monetary Economics, 1989.

${ }^{10}$ Easterly W. and S. Rebelo, "Fiscal Policy and Economic Growth". Journal of Monetary Economics, December 1993.
} 
well as Aschauer (2000), identified that a growth penalty is associated with the ineffective use of public infrastructure investment. ${ }^{11}$

13. However, the growth impact of public investment on growth is also affected by how it is financed. Costly financing can reduce the impact because of negative spillovers on fiscal and external balances and private investment. This is particularly pertinent when, as determined by Vitek (2010) and Aschauer (2000), private investment can have a larger impact on growth than public investment. Indeed, Aschauer (2000) found that external debt financing of public investment could reduce the impact on growth, depending on the quality and effective use of the investment, as well as the financing costs. These considerations emphasize the importance of using costly external financing exclusively for infrastructure projects with a high rate of return, based on feasibility studies to carefully assess projects.

\section{Borrowing and growth impact assumptions}

14. The government is preparing impact studies and will initially focus on projects with a presumed high rate of return on growth and for which the financial viability is assured. The government plans to undertake infrastructure investment financed by nonconcessional borrowing over the medium term ranging between $1 \frac{1}{2}$ and 3 percent of GDP and averaging about 2 percent of GDP per year (US\$300 million from 2011 to 2013 then falling to US\$250 million by 2015). The need for such investment is likely to persist, and the projections incorporate continued nonconcessional borrowing at around 1 percent of GDP.

\section{The growth impact projections for the DSA are broadly in line with recent} studies, as noted above. In line with these findings, this investment is expected to raise real GDP growth by about 1 to $1 \frac{1}{2}$ percentage point over the next few years, with limited spillover effects into the longer term. The rate of return of further investment can be expected to fall, and the investment beyond the medium term is conservatively projected to raise real GDP growth by 0.3 percentage points.

\section{The projections incorporate borrowing by the central government on} concessional and nonconcessional terms. Central government borrowing for its own budgetary spending is assumed to be on IDA and AfDB terms. The grant element on this borrowing averages about 47 percent over the projection period. The projections also incorporate a limited amount of borrowing on nonconcessional terms. The investment projects and the financing modalities are still being finalized, but are currently expected to be mainly financed by sovereign borrowing or through loans mediated by official bilateral creditors (such as the Portuguese credit line) that would be on-lent to implementing SOEs. Accordingly, such nonconcessional borrowing is assumed to have a 10-year maturity, with one year of grace and an interest rate of 5 percent.

\footnotetext{
${ }^{11}$ Hulten, C.R. "Infrastructure Capital and Economic Growth: How Well You Use It May Be More Important than How Much You Have". NBER Working Paper No. 5847, December 1996.
} 


\section{Box 1. Macroeconomic Assumptions 2010-30}

The medium-term assumptions in the baseline scenario for 2010-30 are consistent with the medium-term macroeconomic framework underlying the authorities' request for a successor PSI and with the preliminary outline of the government's updated medium-term development plan.

Real GDP growth is projected to approach 8 percent over the next few years and stabilize around $71 / 2$ percent in the longer term. This includes the impact of higher infrastructure investment raising growth by 1 to $1 \frac{1}{2}$ percentage points in the medium term and by about $1 / 3$ percentage points in the longer term. This represents a deceleration from the annual average above 8 percent over the past decade.

Consumer price inflation is projected to stabilize around $5 \frac{1}{2}$ percent over the forecast period.

External financing. Mozambique is expected to remain reliant on aid flows for the foreseeable future, but this reliance is expected to decline. The grant-equivalent of total external financing is projected to fall from an average of over 11 percent of GDP during 2010-15 toward 7 percent of GDP by the end of the forecast period, in part reflecting a shift in the composition toward loan financing. Concessional borrowing through the budget is projected to trend down from 3.8 percent of GDP in the medium term to 3.4 percent in the longer term. All IDA financing is expected to be through loans. Public sector borrowing, including nonconcessional borrowing, is projected to rise from an annual average of around 5 percent of GDP during 1999-2009 to over 7 percent of GDP during 2010-15, declining toward $4 \frac{1}{2}$ percent of GDP thereafter.

Growth of exports of goods and services is projected to slightly accelerate from about 11 percent per year over 2010-15 to over 12 percent thereafter. This is largely driven by strong growth prospects for megaproject exports from the natural resource sector, for which investment is relatively advanced. Other exports are assumed to increase in line with import demand growth in Mozambique's trade partners.

Import growth is projected to remain steady around 10 percent per year in the medium term, then accelerating to about 11 percent. The strong import growth is driven by both private and public capital inflows. Other imports are assumed to grow at the rate of real GDP growth.

The noninterest current account deficit after grants is projected to widen from about 10 percent of GDP in 2009 to about 12 percent in the medium term because of the increase in public borrowing, as well as high private capital inflows. Beyond the medium term, private capital inflows are expected to rise relative to GDP, offsetting declining public borrowing. The noninterest current account deficit is projected to narrow toward 9 percent of GDP in the longer term, largely because of gains in the trade balance on goods and services.

Fiscal revenues are expected to rise from about 18 percent of GDP in 2009 to about 20 percent of GDP in 2015, largely reflecting a 0.5 percent of GDP annual revenue effort on account of improved revenue administration and a broadening tax base. Over time, nontax revenues from natural resource exploitation, particularly megaprojects, could make a growing contribution to the budget, but the increase of the overall revenue effort is conservatively projected to slow somewhat after 2015. Nevertheless, total revenue is projected to reach about 22 percent of GDP by the end of the forecast period, close to Mozambique's potential tax ratio, as estimated by a number of studies. ${ }^{1}$

The domestic primary balance is assumed to remain steady under 4 percent of GDP, with domestic financing between $1 / 2$ and 1 percent of GDP. Primary spending is projected to rise to nearly 35 percent of GDP in 2015 because of the increase in externally-financed investment, but then levels off to around 31 percent of GDP as external financing declines and debt service payments increase.

${ }^{1}$ See, for example, IMF, 2007, "Mozambique: Evaluation of the Post-Reforms Tax System”. 


\section{External Debt Sustainability Analysis}

\section{Under the baseline scenario, all debt indicators remain well below their} respective thresholds, including in the longer term (Table 2 and Figure 1). However, the debt indicators rise significantly towards their respective thresholds over the next five years, as the authorities make use of the already contracted Portuguese credit lines and step up their borrowing on nonconcessional terms to address the country's infrastructure gap.

- $\quad$ PV of debt: The PV of PPG external debt is projected to rise from 17 percent of GDP in 2009 to about 31 percent in 2015, still noticeably below the relevant debt burden threshold of 40 percent. It would then decline below 25 percent by 2030 . In terms of exports, the PV of PPG debt increases from 67 percent in 2009 to about 112 percent by 2015 - against a threshold of 150 percent — before falling to 68 percent by 2030 . Relative to government revenues, with a debt burden threshold of 250 percent, the PV of PPG debt would rise from 94 percent in 2009 to 154 percent in 2015, before declining to 104 percent by 2030 .

- Debt service: Debt service on PPG external debt would rise from nearly 2 percent of exports in 2009 to $7 \frac{1}{2}$ percent in 2016 before decreasing towards 4 percent by 2030 , thus remaining well below the 20 percent threshold. Debt service on PPG external debt would rise from below 3 percent of fiscal revenues in 2009 to over 11 percent in 2016 before falling towards 6 percent by 2030 .

18. The debt sustainability indicators are sensitive to shocks (Table 3 and Figure 1). ${ }^{12}$ The analysis suggests that the threshold for the PV of debt-to-GDP would be temporarily and marginally breached under a 30 percent depreciation of the exchange rate versus the U.S. dollar (B6) as well as under the combination shock (B5). The stress tests also suggest a heightened vulnerability to adverse export developments (B2). Under the standard export shock, the PV of debt-to-exports ratio reaches 190 percent by 2015, thus exceeding the relevant threshold. However, this shock is extreme as it is based on a standard deviation of exports receipts largely driven by the exceptional circumstances faced in 2009. Export receipts fell sharply in 2009 , mainly because aluminum prices fell by nearly half, and the standard export shock would have implausibly imposed an additional price drop of similar magnitude to the baseline. A modified export shock was designed to capture the historical volatility over the past two decades of prices for aluminum, which accounts for roughly half of Mozambique's export proceeds. Under this modified test, the PV of debt-to-exports ratio reaches, but not exceeds, the relevant threshold. Mozambique's export volatility is expected to decline over the medium term, as its export base will become more diversified. Such

\footnotetext{
${ }^{12}$ The year 2000 is excluded from the stress tests relying on historical data, as macroeconomic performance was skewed by very severe floods and because of large breaks in the data series for the national accounts and balance of payments.
} 
diversification would mainly come from the natural resource sector, as projects are underway or planned to expand electricity, coal, minerals (e.g., titanium) and possibly oil exports.

\section{The debt sustainability indicators are also sensitive to a recurrence of past} macroeconomic circumstances. In this historical scenario (A1), the PV of debt relative to GDP approaches the relevant PV of debt-to-GDP threshold, but remains below it. However, this scenario does not take into account the significant structural changes in the Mozambican economy in the post-civil war period and the considerable improvements in Mozambique's macroeconomic policy environment under successive Fund-supported programs, all of which make a recurrence of the past economic performance unlikely. Among other things, there was a shift in the structure of the economy, as large private capital inflows in the early years of the decade in the natural resources sector subsequently supported a surge in exports and a sharp fall in the current account deficit. Significant donor support helped bolster economic development. On the policy side, the authorities adopted a tighter fiscal and monetary policy stance that helped bring inflation to single digits over time and provided more room for private sector credit. This was also accompanied by exchange rate liberalization and important structural reforms that enhanced the efficiency of the economy. Overall, key economic indicators became less volatile during the period.

\section{The external debt indicators would deteriorate, but remain below their} respective thresholds, if nonconcessional resources are not used productively. ${ }^{13}$ In this high investment-low growth scenario (A3), real GDP growth would remain between $6 \frac{1}{2}$ and 7 percent, or about 1 to $1 \frac{1}{2}$ percentage point below the baseline in the medium term and about $1 / 2$ percentage points in the longer term. This scenario assumes that foreign financing and related spending would remain unchanged relative to the baseline in nominal terms. However, lower domestic revenues generate higher financing requirements that are met by additional external borrowing on commercial terms. To meet the additional external debt service obligations, the government is assumed to reduce domestic primary spending relative to the baseline in nominal terms. By the end of the forecast period, the domestic primary balance deteriorates by about $1 \frac{1}{2}$ percent of GDPcompared to the baseline and the additional financing rises to about 3 percent of GDP.

\section{Public Sector Debt Sustainability}

\section{The evolution of the public debt indicators (including domestic debt) mirrors that of the external indicators because of the predominance of external debt} (Table 4 and Figure 2). This medium-term increase in public debt reflects the temporary surge in public investment financed by external borrowing on nonconcessional terms. However, over the longer term, the public debt stock projections also include a marginal

\footnotetext{
13 This scenario maintains the baseline's assumptions regarding the exchange rate and public external borrowing in U.S. dollar terms.
} 
increase in domestic debt from about 3 percent of GDP at end-2009 to 4 percent of GDP in 2030 that should not affect the availability of credit to the private sector.

\section{Public debt indicators will develop as follows:}

- Mozambique's public debt obligations are expected to rise from 29 percent of GDP at end-2009 to 48 percent of GDP in 2015 and then decline towards 42 percent of GDP by 2030 .

- $\quad$ Similarly, the PV of public debt is projected to rise from 20 percent of GDP at end2009 to over 35 percent of GDP in 2015 before trending back down to 29 percent of GDP by 2030 .

- The evolution of the PV of debt and of debt service relative to revenues (including grants) is similar.

23. The large proportion of external debt makes the public debt burden vulnerable to the same set of shocks as external debt (Table 5). There are, however, some additional risks related to the accumulation of domestic financing. The stress tests indicate that public sector debt ratios are most vulnerable to an increase in other debt-creating flows (B5), to a one-time depreciation of the exchange rate (B4), and also to temporarily lower GDP growth (B1). The debt indicators rise noticeably in the long run when the primary deficit is held unchanged from the high level in 2010 that reflected the easing of the fiscal policy stance during the recent global crisis (A2). This emphasizes the importance of now reversing this policy stance, which the authorities intend to pursue under their successor PSI. Consistent with the program, the primary deficit is projected to temporarily increase by about $1 \frac{1}{2}$ percent of GDP from 2009 to 2011 because ofthe temporary increase in externallyfinanced investment, but the domestic portion of the balance is projected to improve by nearly 1 percent of GDP between 2009 and 2015.

\section{VIEWS OF THE AUTHORITIES}

24. The authorities are in broad agreement with the conclusions. A preliminary draft of the DSA and, in particular, the implications of scaling up infrastructure investment financed by nonconcessional borrowing were extensively discussed with the authorities. While broadly agreeing with the findings, the authorities reiterated their intention to adopt a cautious approach to nonconcessional borrowing and ensure that such borrowing would exclusively be channeled to infrastructure projects with a high economic rate of return. In their view, such an approach would be consistent with their overriding objective of preserving their strong track record with respect to macroeconomic stability. Finally, as mentioned above, the authorities committed to strengthening their debt management and develop a medium-term debt strategy to be able to make informed borrowing decisions. These intentions have been anchored in their new PSI-supported economic program. 


\section{Conclusions}

25. In the staffs' view, Mozambique continues to face a low risk of debt distress. Its external debt levels are expected to remain below their indicative thresholds for debt distress. However, the government's plans to temporarily increase public investment financed by external borrowing on nonconcessional terms, in line with the Fund's revised Debt Limits Policy, will noticeably increase debt vulnerabilities, as debt ratios under the stress tests approach, and in some instances temporarily and marginally exceed, the relevant thresholds. Although Mozambique's public debt is expected to decline beyond the medium term, stress tests suggest vulnerabilities, mirroring the large share of external debt in total debt.

\section{This calls for a cautious approach with nonconcessional borrowing and resolve} to improve debt management capacity. Where possible, the authorities should continue to rely on concessional borrowing and grants to minimize future debt service, and any nonconcessional external financing of new projects ought to be considered case by case, based on economic return, impact on debt sustainability, and potential effects on the financing decisions of donors and concessional lenders. The authorities' commitments under the successor PSI, including with respect to the continued pursuit of prudent macroeconomic

policies and structural reforms to boost their debt management capacity, should be conducive to containing debt vulnerabilities. 
Table 2.: External Debt Sustainability Framework, Baseline Scenario, 2007-2030 1/

(In percent of GDP, unless otherwise indicated)

\begin{tabular}{|c|c|c|c|c|c|c|c|c|c|c|c|c|c|c|c|}
\hline & \multicolumn{3}{|c|}{ Actual } & \multirow{3}{*}{$\begin{array}{c}\text { Historical } \\
\text { Average } \\
2001-09 \\
\end{array}$} & \multirow{3}{*}{$\begin{array}{r}\text { Standard } \\
\text { Deviation } \\
2001-09 \\
\end{array}$} & \multicolumn{6}{|c|}{ Projections } & \multirow[b]{2}{*}{$2010-2015$} & \multirow{2}{*}{\multicolumn{3}{|c|}{$2016-2030$}} \\
\hline & & & & & & & & & & & & & & & \\
\hline & 2007 & 2008 & 2009 & & & 2010 & 2011 & 2012 & 2013 & 2014 & 2015 & Average & 2020 & 2030 & Average \\
\hline External debt (nominal) $1 /$ & 57.3 & 49.7 & 52.5 & 87.6 & 36.9 & 55.5 & 61.6 & 63.3 & 63.7 & 65.1 & 66.3 & 62.6 & 64.9 & 62.7 & 64.3 \\
\hline $\mathrm{o} /$ w public and publicly guaranteed (PPG) & 18.0 & 21.3 & 26.0 & 62.0 & 38.6 & 32.1 & 36.3 & 39.0 & 40.7 & 42.9 & 44.2 & 39.2 & 41.7 & 37.6 & 40.3 \\
\hline Change in external debt & -7.5 & -7.6 & 2.8 & -11.3 & 16.7 & 2.9 & 6.1 & 1.7 & 0.5 & 1.4 & 1.2 & 2.3 & 0.5 & -0.4 & -0.2 \\
\hline Identified net debt-creating flows & -2.8 & -4.5 & 3.5 & 0.2 & 7.6 & 1.4 & 2.1 & 3.2 & 3.2 & 2.6 & 2.1 & 2.4 & 1.4 & 1.4 & 1.8 \\
\hline Non-interest current account deficit & 7.9 & 9.6 & 10.4 & 10.9 & 3.7 & 12.1 & 11.6 & 12.0 & 11.6 & 11.0 & 10.7 & 11.5 & 9.9 & 9.2 & 9.8 \\
\hline Deficit in balance of goods and services & 9.8 & 14.1 & 18.7 & 14.4 & 4.4 & 19.1 & 17.7 & 17.5 & 17.6 & 17.3 & 17.3 & 17.8 & 15.5 & 10.8 & 14.2 \\
\hline Exports & 35.4 & 32.3 & 25.1 & 30.3 & 4.8 & 26.8 & 30.9 & 29.8 & 28.3 & 27.9 & 28.1 & 28.6 & 30.2 & 36.1 & 32.0 \\
\hline Imports & 45.2 & 46.5 & 43.8 & 44.8 & 3.2 & 45.9 & 48.6 & 47.3 & 46.0 & 45.2 & 45.4 & 46.4 & 45.7 & 46.9 & 46.2 \\
\hline Net current trans fers (negative $=$ inflow) & -7.4 & -8.6 & -7.8 & -7.4 & 3.2 & -7.8 & -8.5 & -8.3 & -8.2 & -8.2 & -8.2 & -8.2 & -6.9 & -5.4 & -6.4 \\
\hline $\mathrm{o} / \mathrm{w}$ official & -6.3 & -7.7 & -6.9 & -7.1 & 3.1 & -6.9 & -7.6 & -7.5 & -7.4 & -7.4 & -7.4 & -7.4 & -6.0 & -4.5 & -5.6 \\
\hline Other current account flows (negative $=$ net inflow) & 5.5 & 4.0 & -0.6 & 3.9 & 3.5 & 0.7 & 2.4 & 2.7 & 2.2 & 1.9 & 1.6 & 1.9 & 1.2 & 3.8 & 2.0 \\
\hline Net FDI (negative = inflow) & -5.3 & -5.9 & -8.9 & -5.5 & 2.5 & -9.0 & -6.8 & -6.1 & -5.8 & -5.9 & -6.1 & -6.6 & -6.4 & -5.9 & -6.1 \\
\hline Endogenous debt dynamics 2/ & -5.4 & -8.1 & 2.0 & -5.1 & 6.9 & -1.7 & -2.7 & -2.6 & -2.6 & -2.4 & -2.6 & -2.4 & -2.0 & -1.9 & -2.0 \\
\hline Contribution from nominal interest rate & 1.8 & 2.3 & 1.6 & 2.5 & 0.8 & 1.6 & 1.3 & 1.5 & 1.8 & 2.0 & 2.1 & 1.7 & 2.2 & 2.4 & 2.3 \\
\hline Contribution from real GDP growth & -4.2 & -3.2 & -3.2 & -7.9 & 5.5 & -3.3 & -4.0 & -4.2 & -4.4 & -4.5 & -4.7 & -4.2 & -4.2 & -4.3 & -4.3 \\
\hline Contribution from price and exchange rate changes & -3.0 & -7.2 & 3.6 & 0.2 & 10.6 & $\ldots$ & $\ldots$ & $\ldots$ & $\ldots$ & $\ldots$ & $\ldots$ & & $\ldots$ & $\ldots$ & \\
\hline Residual (3-4) 3/ & -4.8 & -3.1 & -0.6 & -11.5 & 17.1 & 1.5 & 4.0 & -1.5 & -2.8 & -1.3 & -0.8 & -0.1 & -0.9 & -1.8 & -2.0 \\
\hline $\mathrm{o} / \mathrm{w}$ exceptional financing & -1.8 & -0.2 & 0.0 & -9.9 & 13.3 & 0.0 & 0.0 & 0.0 & 0.0 & 0.0 & 0.0 & 0.0 & 0.0 & 0.0 & 0.0 \\
\hline PV of external debt 4/ & $\ldots$ & $\ldots$ & 43.3 & 43.3 & & 44.1 & 50.0 & 51.6 & 52.0 & 52.7 & 53.4 & 50.6 & 51.5 & 49.8 & 51.1 \\
\hline In percent of exports & $\ldots$ & $\ldots$ & 172.6 & 172.6 & & 164.2 & 161.7 & 173.1 & 183.4 & 188.9 & 190.4 & 176.9 & 170.9 & 137.9 & 160.7 \\
\hline PV of PPG external debt & $\ldots$ & $\ldots$ & 16.8 & 16.8 & & 20.7 & 24.7 & 27.3 & 28.9 & 30.5 & 31.3 & 27.2 & 28.3 & 24.7 & 27.1 \\
\hline In percent of exports & ... & ... & 66.9 & 66.9 & & 77.0 & 79.8 & 91.6 & 101.9 & 109.2 & 111.5 & 95.2 & 93.9 & 68.2 & 85.6 \\
\hline In percent of government revenues & $\ldots$ & $\ldots$ & 94.5 & 94.5 & & 112.1 & 131.8 & 142.4 & 146.9 & 152.5 & 154.0 & 139.9 & 134.6 & 103.8 & 124.3 \\
\hline Debt service-to-exports ratio (in percent) & 40.7 & 19.2 & 20.0 & 23.8 & 7.0 & 17.4 & 11.3 & 12.8 & 17.4 & 21.6 & 23.1 & 17.3 & 24.4 & 23.5 & 24.6 \\
\hline PPG debt s ervice-to-exports ratio (in percent) & 1.7 & 1.6 & 1.9 & 2.8 & 1.0 & 2.9 & 2.3 & 3.4 & 4.9 & 6.4 & 7.7 & 4.6 & 6.4 & 4.2 & 5.8 \\
\hline PPG debt service-to-revenue ratio (in percent) & 3.7 & 3.1 & 2.7 & 6.2 & 2.6 & 4.2 & 3.7 & 5.3 & 7.1 & 8.9 & 10.7 & 6.7 & 9.2 & 6.4 & 8.4 \\
\hline Total gross financing need (Billions of U.S. dollars) & 1.4 & 1.0 & 0.6 & 0.9 & 0.3 & 0.8 & 0.9 & 1.2 & 1.5 & 1.7 & 1.9 & 1.3 & 2.9 & 8.7 & 4.8 \\
\hline Non-interest current account deficit that stabilizes debt ratio & 15.5 & 17.2 & 7.6 & 22.2 & 17.8 & 9.1 & 5.5 & 10.3 & 11.2 & 9.6 & 9.5 & 9.2 & 9.3 & 9.6 & 10.1 \\
\hline \multicolumn{16}{|l|}{ Key macroeconomic assumptions } \\
\hline Real GDP growth (in percent) & 7.3 & 6.7 & 6.3 & 8.0 & 2.0 & 6.5 & 7.5 & 7.6 & 7.9 & 7.8 & 7.8 & 7.5 & 7.2 & 7.5 & 7.3 \\
\hline GDP deflator in US dollar terms (change in percent) & 4.9 & 14.4 & -6.8 & 2.2 & 9.0 & -2.4 & -2.1 & 5.2 & 5.3 & 3.0 & 0.7 & 1.6 & 3.0 & 2.9 & 2.9 \\
\hline Effective interest rate (percent) $5 /$ & 3.1 & 4.8 & 3.2 & 3.1 & 1.2 & 3.2 & 2.5 & 2.8 & 3.3 & 3.6 & 3.5 & 3.1 & 3.8 & 4.2 & 3.9 \\
\hline Growth of exports of G\&S (US dollar terms, in percent) & 3.7 & 11.8 & -23.2 & 16.7 & 18.4 & 11.2 & 21.2 & 9.1 & 8.1 & 9.4 & 9.2 & 11.4 & 10.6 & 13.4 & 12.3 \\
\hline Growth of imports of G\&S (US dollar terms, in percent) & 7.6 & 25.7 & -6.6 & 12.9 & 11.9 & 9.0 & 11.3 & 10.4 & 10.3 & 9.2 & 9.0 & 9.9 & 10.7 & 11.1 & 10.7 \\
\hline Grant element of new public sector borrowing (in percent) & $\ldots$ & $\ldots$ & $\ldots$ & $\ldots$ & $\ldots$ & 39.0 & 23.4 & 24.8 & 26.3 & 29.6 & 30.9 & 29.0 & 34.4 & 35.9 & 35.6 \\
\hline Government revenues (excluding grants, in percent of GDP) & 15.9 & 16.0 & 17.8 & 14.2 & 2.1 & 18.4 & 18.7 & 19.2 & 19.7 & 20.0 & 20.3 & 19.4 & 21.1 & 23.8 & 21.9 \\
\hline Aid flows (in Billions of US dollars) 7/ & 0.9 & 1.2 & 0.9 & 0.8 & 0.2 & 1.4 & 1.4 & 1.6 & 1.8 & 2.0 & 2.2 & 1.7 & 3.0 & 6.3 & 3.9 \\
\hline $\mathrm{o} / \mathrm{w}$ Grants & 0.8 & 0.9 & 0.9 & 0.6 & 0.2 & 0.9 & 1.0 & 1.1 & 1.3 & 1.4 & 1.5 & 1.2 & 2.0 & 3.9 & 2.5 \\
\hline $\mathrm{o} / \mathrm{w}$ Concessional loans & 0.2 & 0.2 & 0.0 & 0.2 & 0.1 & 0.5 & 0.4 & 0.5 & 0.5 & 0.6 & 0.6 & 0.5 & 1.0 & 2.5 & 1.4 \\
\hline Grant-equivalent financing (in percent of GDP) $8 /$ & $\ldots$ & $\ldots$ & $\ldots$ & & & 11.3 & 11.3 & 11.2 & 11.1 & 11.1 & 11.0 & 11.2 & 9.1 & 6.8 & 8.4 \\
\hline Grant-equivalent financing (in percent of external financing) 8/ & $\ldots$ & $\ldots$ & $\ldots$ & & & 74.2 & 64.4 & 66.0 & 67.7 & 70.9 & 72.4 & 69.3 & 73.9 & 71.0 & 73.6 \\
\hline \multicolumn{16}{|l|}{ Memorandum items: } \\
\hline Nominal GDP (Billions of US dollars) & 8.1 & 9.9 & 9.8 & 6.7 & 2.3 & 10.2 & 10.8 & 12.2 & 13.8 & 15.4 & 16.7 & 13.2 & 27.2 & 74.0 & 40.2 \\
\hline Nominal dollar GDP growth & 12.6 & 22.1 & -0.9 & 10.3 & 8.9 & 3.9 & 5.3 & 13.2 & 13.6 & 11.0 & 8.6 & 9.3 & 10.4 & 10.6 & 10.4 \\
\hline PV of PPG external debt (in Billions of US dollars) & & & 1.6 & & & 2.0 & 2.7 & 3.3 & 4.0 & 4.6 & 5.1 & 3.6 & 7.6 & 18.0 & 10.5 \\
\hline (PVt-PVt-1)/GDPt-1 (in percent) & & & & & & 4.0 & 6.6 & 6.4 & 5.5 & 4.2 & 3.4 & 5.0 & 2.5 & 2.4 & 2.4 \\
\hline
\end{tabular}

Sources: Country authorities; and staff estimates and projections.

1/ Includes both public and private sector external debt. Assumes the provision of debt relief by all bilateral creditors on comparable terms at the time of the HIPC completion point.

2/ Derived as $[\mathrm{r}-\mathrm{g}-\rho(1+\mathrm{g})] /(1+\mathrm{g}+\rho+\mathrm{g} \rho)$ times previous period debt ratio, with $\mathrm{r}=$ nominal interest rate; $\mathrm{g}=$ real GDP growth rate, and $\rho=$ growth rate of GDP deflator in U.S. dollar terms.

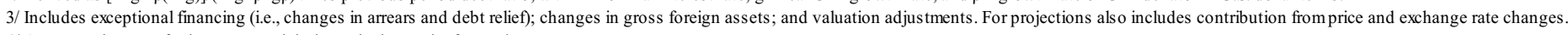

4/ Assumes that PV of private sector debt is equivalent to its face value.

5/ Current-year interest payments divided by previous period debt stock.

6/ Historical averages and standard deviations are generally derived over the years 2001-09, subject to data availability.

7/ Defined as grants, concessional loans, and debt relief.

8/ Grant-equivalent financing includes grants provided directly to the government and through new borrowing (difference between the face value and the PV of new debt). 


\begin{tabular}{|c|c|c|c|c|c|c|c|c|c|}
\hline & & & & & ections & & & & \\
\hline & 2010 & 2011 & 2012 & 2013 & 2014 & 2015 & 2020 & 2025 & 2030 \\
\hline PV of debt- & ratio & & & & & & & & \\
\hline Baseline & 20.7 & 24.7 & 27.3 & 28.9 & 30.5 & 31.3 & 28.3 & 26.1 & 24.7 \\
\hline A. Alternative Scenarios & & & & & & & & & \\
\hline A1. Key variables at their historical averages in 2010-2030 1/ & 20.7 & 24.2 & 27.2 & 29.2 & 30.5 & 31.3 & 33.6 & 34.6 & 35.6 \\
\hline A3. Alternative Scenario: No Growth Impact of NCB-Financed Investment & 20.7 & 25.1 & 28.6 & 31.0 & 33.0 & 35.1 & 36.3 & 37.3 & 39.3 \\
\hline B. Bound Tests & & & & & & & & & \\
\hline B1. Real GDP growth at historical average minus one standard deviation in 2011-2012 & 20.7 & 25.0 & 28.2 & 29.9 & 30.8 & 31.6 & 28.7 & 26.4 & 24.9 \\
\hline B2. Export value growth at historical average minus one standard deviation in 2011-2012 3/ & 20.7 & 27.5 & 33.2 & 34.3 & 34.9 & 35.4 & 31.0 & 27.4 & 25.1 \\
\hline B3. US dollar GDP deflator at historical average minus one standard deviation in 2011-2012 & 20.7 & 25.9 & 32.5 & 34.4 & 35.5 & 36.4 & 33.0 & 30.3 & 28.7 \\
\hline B4. Net non-debt creating flows at historical average minus one standard deviation in 2011-2012 4/ & 20.7 & 30.6 & 38.2 & 38.8 & 39.0 & 39.4 & 33.7 & 28.9 & 25.9 \\
\hline B5. Combination of B1-B4 using one-half standard deviation shocks & 20.7 & 30.6 & 41.2 & 41.9 & 42.2 & 42.6 & 36.5 & 31.3 & 28.2 \\
\hline B6. One-time 30 percent nominal depreciation relative to the baseline in 2011 5/ & 20.7 & 35.6 & 39.6 & 41.8 & 43.2 & 44.3 & 40.2 & 36.9 & 34.9 \\
\hline PV of de bt-to & ts rati & & & & & & & & \\
\hline Baseline & 77.0 & 79.8 & 91.6 & 101.9 & 109.2 & 111.5 & 93.9 & 79.9 & 68.2 \\
\hline A. Alternative Scenarios & & & & & & & & & \\
\hline A1. Key variables at their historical averages in 2010-2030 1/ & 77.0 & 78.4 & 91.3 & 103.1 & 109.2 & 111.5 & 111.6 & 106.1 & 98.4 \\
\hline A3. Alternative Scenario: No Growth Impact of NCB-Financed Investment & 77.0 & 81.3 & 95.9 & 109.5 & 118.4 & 125.1 & 120.2 & 114.5 & 108.8 \\
\hline B. Bound Tests & & & & & & & & & \\
\hline B1. Real GDP growth at historical average minus one standard deviation in 2011-2012 & 77.0 & 79.9 & 92.1 & 102.4 & 107.3 & 109.5 & 92.5 & 78.5 & 67.0 \\
\hline B2. Export value growth at historical average minus one standard deviation in 2011-2012 3/ & 77.0 & 101.5 & 130.7 & 141.8 & 146.3 & 147.8 & 120.6 & 98.4 & 81.5 \\
\hline B3. US dollar GDP deflator at historical average minus one standard deviation in 2011-2012 & 77.0 & 79.9 & 92.1 & 102.4 & 107.3 & 109.5 & 92.5 & 78.5 & 67.0 \\
\hline B4. Net non-debt creating flows at historical average minus one standard deviation in 2011-2012 4/ & 77.0 & 99.1 & 128.1 & 136.8 & 139.8 & 140.3 & 111.8 & 88.6 & 71.7 \\
\hline B5. Combination of B1-B4 using one-half standard deviation shocks & 77.0 & 106.9 & 135.0 & 144.4 & 147.7 & 148.2 & 118.3 & 93.9 & 76.2 \\
\hline B6. One-time 30 percent nominal depreciation relative to the baseline in $20115 /$ & 77.0 & 79.9 & 92.1 & 102.4 & 107.3 & 109.5 & 92.5 & 78.5 & 67.0 \\
\hline PV of debt-to & ue rati & & & & & & & & \\
\hline Baseline & 112 & 132 & 142 & 147 & 152 & 154 & 135 & 117 & 104 \\
\hline A. Alternative Scenarios & & & & & & & & & \\
\hline A1. Key variables at their historical averages in 2010-2030 1/ & 112 & 129 & 142 & 149 & 152 & 154 & 160 & 155 & 150 \\
\hline A3. Alternative Scenario: No Growth Impact of NCB-Financed Investment & 112 & 134 & 149 & 158 & 165 & 173 & 172 & 167 & 166 \\
\hline B. Bound Tests & & & & & & & & & \\
\hline B1. Real GDP growth at historical average minus one standard deviation in 2011-2012 & 112 & 134 & 147 & 152 & 154 & 156 & 136 & 118 & 105 \\
\hline B2. Export value growth at historical average minus one standard deviation in 2011-2012 3/ & 112 & 147 & 173 & 175 & 174 & 174 & 147 & 122 & 106 \\
\hline B3. US dollar GDP deflator at historical average minus one standard deviation in 2011-2012 & 112 & 139 & 170 & 175 & 178 & 179 & 157 & 136 & 121 \\
\hline B4. Net non-debt creating flows at historical average minus one standard deviation in 2011-2012 4/ & 112 & 164 & 199 & 197 & 195 & 194 & 160 & 129 & 109 \\
\hline B5. Combination of B1-B4 using one-half standard deviation shocks & 112 & 164 & 215 & 213 & 211 & 210 & 174 & 140 & 119 \\
\hline B6. One-time 30 percent nominal depreciation relative to the baseline in $20115 /$ & 112 & 190 & 206 & 213 & 216 & 218 & 191 & 165 & 147 \\
\hline Debt service- & rts rat & & & & & & & & \\
\hline Baseline & 2.9 & 2.3 & 3.4 & 4.9 & 6.4 & 7.7 & 6.4 & 5.1 & 4.2 \\
\hline A. Alternative Scenarios & & & & & & & & & \\
\hline A1. Key variables at their historical averages in 2010-2030 1/ & 2.9 & 2.2 & 3.4 & 5.0 & 6.5 & 7.7 & 6.8 & 5.9 & 5.5 \\
\hline A3. Alternative Scenario: No Growth Impact of NCB-Financed Investment & 2.9 & 2.3 & 3.5 & 5.2 & 7.1 & 9.0 & 10.3 & 10.7 & 10.9 \\
\hline B. Bound Tests & & & & & & & & & \\
\hline B1. Real GDP growth at historical average minus one standard deviation in 2011-2012 & 2.9 & 2.3 & 3.4 & 4.9 & 6.4 & 7.7 & 6.4 & 5.1 & 4.2 \\
\hline B2. Export value growth at historical average minus one standard deviation in 2011-2012 3/ & 2.9 & 2.6 & 4.3 & 6.3 & 8.0 & 9.5 & 8.4 & 6.5 & 5.2 \\
\hline B3. US dollar GDP deflator at historical average minus one standard deviation in 2011-2012 & 2.9 & 2.3 & 3.4 & 4.9 & 6.4 & 7.7 & 6.4 & 5.1 & 4.2 \\
\hline B4. Net non-debt creating flows at historical average minus one standard deviation in 2011-2012 4/ & 2.9 & 2.3 & 3.9 & 5.8 & 7.2 & 8.5 & 7.8 & 5.9 & 4.6 \\
\hline B5. Combination of B1-B4 using one-half standard deviation shocks & 2.9 & 2.5 & 4.1 & 6.1 & 7.6 & 9.0 & 8.2 & 6.2 & 4.9 \\
\hline B6. One-time 30 percent nominal depreciation relative to the baseline in 2011 5/ & 2.9 & 2.3 & 3.4 & 4.9 & 6.4 & 7.7 & 6.4 & 5.1 & 4.2 \\
\hline Debt service- 1 & tue ra & & & & & & & & \\
\hline Baseline & 4.2 & 3.7 & 5.3 & 7.1 & 8.9 & 10.7 & 9.2 & 7.4 & 6.4 \\
\hline A. Alternative Scenarios & & & & & & & & & \\
\hline A1. Key variables at their historical averages in 2010-2030 1/ & 4.2 & 3.6 & 5.3 & 7.2 & 9.0 & 10.7 & 9.7 & 8.6 & 8.3 \\
\hline A3. Alternative Scenario: No Growth Impact of NCB-Financed Investment & 4.2 & 3.8 & 5.4 & 7.5 & 9.9 & 12.4 & 14.7 & 15.5 & 16.6 \\
\hline B. Bound Tests & & & & & & & & & \\
\hline B1. Real GDP growth at historical average minus one standard deviation in 2011-2012 & 4.2 & 3.8 & 5.4 & 7.3 & 9.2 & 11.0 & 9.4 & 7.6 & 6.6 \\
\hline B2. Export value growth at historical average minus one standard deviation in 2011-2012 3/ & 4.2 & 3.7 & 5.6 & 7.8 & 9.5 & 11.3 & 10.2 & 8.0 & 6.8 \\
\hline B3. US dollar GDP deflator at historical average minus one standard deviation in 2011-2012 & 4.2 & 3.9 & 6.3 & 8.4 & 10.5 & 12.6 & 10.8 & 8.8 & 7.6 \\
\hline B4. Net non-debt creating flows at historical average minus one standard deviation in 2011-2012 4/ & 4.2 & 3.7 & 6.0 & 8.4 & 10.1 & 11.7 & 11.1 & 8.6 & 7.1 \\
\hline B5. Combination of B1-B4 using one-half standard deviation shocks & 4.2 & 3.8 & 6.5 & 9.1 & 10.9 & 12.8 & 12.0 & 9.3 & 7.7 \\
\hline B6. One-time 30 percent nominal depreciation relative to the baseline in $20115 /$ & 4.2 & 5.4 & 7.6 & 10.2 & 12.8 & 15.4 & 13.2 & 10.7 & 9.2 \\
\hline Memorandum item: & & & & & & & & & \\
\hline Grant element assumed on residual financing (i.e., financing required above baseline) $6 /$ & 26 & 26 & 26 & 26 & 26 & 26 & 26 & 26 & 26 \\
\hline
\end{tabular}

Sources: Country authorities; and staff estimates and projections.

1/ Variables include real GDP growth, growth of GDP deflator (in U.S. dollar terms), non-interest current account in percent of GDP, and non-debt creating flows.

2/ The stress test A2, borrowing on less favourable terms, has been dropped as it is not appropriate in this case. Given the commercial financing terms for the investment projects, the A2 scenario would yield unrealistic results, as marginal borrowing under this test is calculated on the average terms of new borrowing, therefore assuming harsher terms than Mozambique would face in the need to cover a financing gap.

3/ Exports values are assumed to remain permanently at the lower level, but the current account as a share of GDP is assumed to return to its baseline level after the shock (implicitly assumin an offsetting adjustment in import levels).

4/ Includes official and private transfers and FDI

5/ Depreciation is defined as percentage decline in dollar/local currency rate, such that it never exceeds 100 percent

6/ Applies to all stress scenarios except for A3 in which the terms on all new financing are on commercial terms. 
Figure 1. Mozambique: Indicators of Public and Publicly Guaranteed External Debt under Alternatives Scenarios, 2010-2030 1/
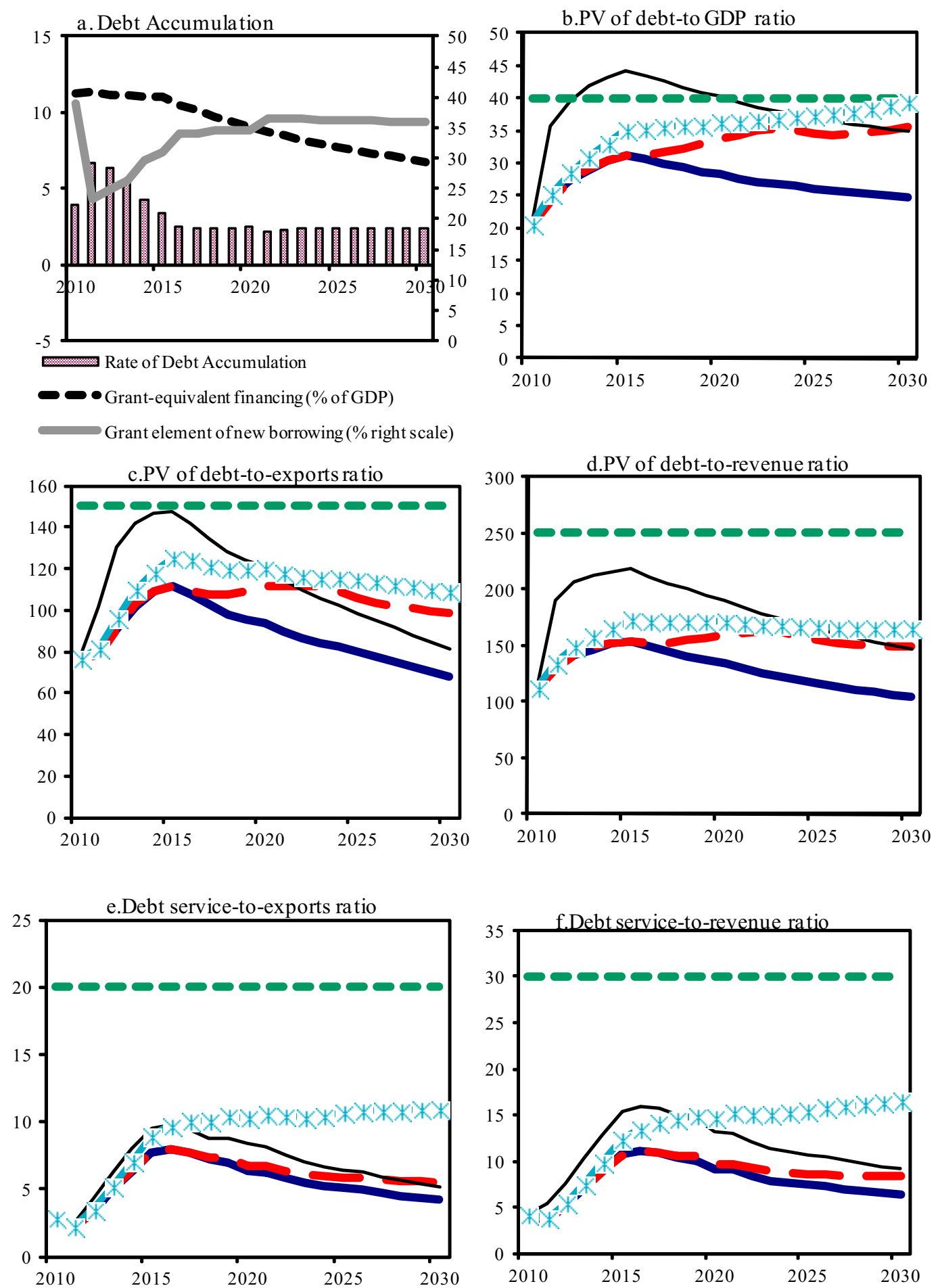

Sources: Country authorities; and staff estimates and projections.

Baseline Historical scenario $\longrightarrow$ Most extreme shock $1 / 0 \bullet \bullet$ Threshold $-m$ No Impact

1/ The most extreme stress test is the test that yields the highest ratio in 2020. In figure b. it corresponds to a One-time depreciation shock; in c. to a Exports shock; in d. to a One-time depreciation shock; in e. to a

Exports shock and in figure f. to a One-time depreciation shock 
Table 4.Mozambique: Public Sector Debt Sustainability Framework, Baseline Scenario, 2007-2030

(In percent of GDP, unless otherwise indicated)

\begin{tabular}{|c|c|c|c|c|c|c|c|c|c|c|c|c|c|c|c|}
\hline & \multicolumn{3}{|c|}{ Actual } & \multirow{2}{*}{$\begin{array}{c}2001-09 \\
\text { Average }\end{array}$} & \multirow{2}{*}{$\begin{array}{c}2001-09 \\
\text { Standard } \\
\text { Deviation }\end{array}$} & \multirow{2}{*}{$\begin{array}{c}\text { Estimate } \\
2010 \\
\end{array}$} & \multirow[b]{2}{*}{2011} & \multirow[b]{2}{*}{2012} & \multirow[b]{2}{*}{2013} & \multicolumn{3}{|c|}{ Projections } & \multirow[b]{2}{*}{2020} & \multirow[b]{2}{*}{2030} & \multirow[b]{2}{*}{$\begin{array}{l}2016-30 \\
\text { Average } \\
\end{array}$} \\
\hline & 2007 & 2008 & 2009 & & & & & & & 2014 & 2015 & $\begin{array}{l}2010-15 \\
\text { Average } \\
\end{array}$ & & & \\
\hline $\begin{array}{l}\text { Public sector debt } 1 / \\
\mathrm{o} / \mathrm{w} \text { foreign-currency denominated }\end{array}$ & $\begin{array}{l}21.9 \\
18.0\end{array}$ & $\begin{array}{l}25.4 \\
21.3\end{array}$ & $\begin{array}{l}29.3 \\
26.0\end{array}$ & $\begin{array}{l}66.4 \\
62.0\end{array}$ & $\begin{array}{l}38.1 \\
38.6\end{array}$ & $\begin{array}{l}35.1 \\
32.1\end{array}$ & $\begin{array}{l}39.2 \\
36.3\end{array}$ & $\begin{array}{l}42.4 \\
39.0\end{array}$ & $\begin{array}{l}44.4 \\
40.7\end{array}$ & $\begin{array}{l}46.8 \\
42.9\end{array}$ & $\begin{array}{l}48.4 \\
44.2\end{array}$ & $\begin{array}{l}42.7 \\
39.2\end{array}$ & $\begin{array}{l}46.4 \\
41.7\end{array}$ & $\begin{array}{l}42.0 \\
37.6\end{array}$ & $\begin{array}{l}45.2 \\
40.3\end{array}$ \\
\hline Change in public sector debt & -31.8 & 3.6 & 3.9 & -11.4 & 20.7 & 5.8 & 4.1 & 3.2 & 2.0 & 2.4 & 1.5 & 3.2 & -0.2 & -0.5 & -0.4 \\
\hline Identified debt-creating flows & -8.5 & 0.4 & 4.8 & -4.6 & 11.4 & 3.8 & 3.3 & 2.1 & 1.0 & 1.7 & 1.2 & 2.2 & 0.1 & -0.5 & -0.2 \\
\hline Primary deficit & 2.3 & 1.9 & 5.1 & 3.3 & 1.3 & 4.1 & 6.6 & 6.0 & 5.1 & 4.2 & 3.9 & 5.0 & 3.4 & 2.6 & 3.0 \\
\hline Revenue and grants & 25.2 & 25.4 & 27.4 & 23.1 & 2.4 & 27.2 & 28.1 & 28.4 & 28.9 & 29.2 & 29.5 & 28.5 & 28.4 & 29.0 & 28.7 \\
\hline of which: grants & 9.3 & 9.4 & 9.6 & 8.8 & 1.6 & 8.8 & 9.4 & 9.3 & 9.2 & 9.2 & 9.2 & 9.2 & 7.4 & 5.2 & \\
\hline Primary (noninterest) expenditure & 27.5 & 27.3 & 32.4 & 26.4 & 3.0 & 31.3 & 34.7 & 34.4 & 34.0 & 33.4 & 33.4 & 33.5 & 31.8 & 31.6 & 31.7 \\
\hline Automatic debt dynamics & -9.9 & -1.2 & 0.0 & -6.3 & 10.7 & -0.1 & -3.3 & -3.9 & -4.1 & -2.5 & -2.7 & -2.8 & -3.3 & -3.1 & -3.2 \\
\hline Contribution from interest rate/growth differential & -5.5 & -3.2 & 0.3 & -5.1 & 5.3 & -0.8 & -1.3 & -3.8 & -4.1 & -3.4 & -2.7 & -2.7 & -3.3 & -3.1 & -3.2 \\
\hline of which: contribution from average real interest rate & -1.9 & -1.8 & 1.9 & 1.1 & 7.7 & 1.0 & 1.1 & -1.0 & -1.0 & -0.2 & 0.7 & 0.1 & -0.2 & -0.1 & -0.1 \\
\hline of which: contribution from real GDP growth & -3.6 & -1.4 & -1.5 & -6.2 & 4.4 & -1.8 & -2.5 & -2.8 & -3.1 & -3.2 & -3.4 & -2.8 & -3.1 & -3.0 & -3.1 \\
\hline Contribution from real exchange rate depreciation & -4.4 & 2.0 & -0.4 & -1.2 & 8.4 & 0.7 & -2.0 & -0.1 & 0.0 & 0.9 & 0.0 & -0.1 & $\ldots$ & $\ldots$ & 0.0 \\
\hline Other identified debt-creating flows & -0.9 & -0.3 & -0.3 & -1.6 & 1.1 & -0.2 & 0.0 & 0.0 & 0.0 & 0.0 & 0.0 & 0.0 & 0.0 & 0.0 & 0.0 \\
\hline Privatization receipts (negative) & 0.0 & 0.0 & -0.2 & -0.3 & 0.6 & -0.1 & 0.0 & 0.0 & 0.0 & 0.0 & 0.0 & 0.0 & 0.0 & 0.0 & 0.0 \\
\hline Recognition of implicit or contingent liabilities & 0.0 & 0.0 & 0.0 & 0.0 & 0.0 & 0.0 & 0.0 & 0.0 & 0.0 & 0.0 & 0.0 & 0.0 & 0.0 & 0.0 & 0.0 \\
\hline Debt relief (HIPC and other) & -0.9 & -0.3 & -0.1 & -1.3 & 0.8 & -0.1 & 0.0 & 0.0 & 0.0 & 0.0 & 0.0 & 0.0 & 0.0 & 0.0 & 0.0 \\
\hline Other (specify, e.g. bank recapitalization) & 0.0 & 0.0 & 0.0 & 0.0 & 0.0 & 0.0 & 0.0 & 0.0 & 0.0 & 0.0 & 0.0 & 0.0 & 0.0 & 0.0 & \\
\hline Residual, including asset changes & -23.3 & 3.2 & -0.9 & -6.8 & 15.4 & 2.0 & 0.8 & 1.1 & 1.0 & 0.7 & 0.3 & 1.0 & -0.3 & -0.1 & -0.2 \\
\hline \multicolumn{16}{|l|}{ Other S ustainability Indicators } \\
\hline PV of public sector debt & 35.2 & 33.2 & 20.0 & 13.0 & 13.1 & 23.7 & 27.6 & 30.7 & 32.7 & 34.4 & 35.4 & 30.8 & 33.0 & 29.1 & 32.0 \\
\hline $\mathrm{o} / \mathrm{w}$ foreign-currency denominated & 31.3 & 29.0 & 16.8 & 8.6 & 13.4 & 20.7 & 24.7 & 27.3 & 28.9 & 30.5 & 31.3 & 27.2 & 28.3 & 24.7 & 27.1 \\
\hline $\mathrm{o} / \mathrm{w}$ external & 31.3 & 29.0 & 16.8 & 25.7 & 7.8 & 20.7 & 24.7 & 27.3 & 28.9 & 30.5 & 31.3 & 27.2 & 28.3 & 24.7 & 27.1 \\
\hline PV of contingent liabilities (not included in public sector debt) & 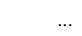 & $\ldots$ & & & & $\ldots$ & & $\ldots$ & $\ldots$ & $\ldots$ & $\ldots$ & & $\ldots$ & $\ldots$ & \\
\hline Gross financing need $2 /$ & 3.5 & 3.1 & 6.0 & 5.0 & 1.2 & 5.4 & 7.7 & 7.4 & 7.0 & 6.4 & 6.6 & 6.8 & 5.9 & 4.8 & \\
\hline $\mathrm{PV}$ of public sector debt-to-revenue and grants ratio (in percent) & 139.6 & 130.7 & 73.2 & 52.9 & 50.2 & 87.2 & 98.2 & 108.0 & 113.2 & 118.1 & 120.2 & 107.5 & 116.1 & 100.5 & 111.6 \\
\hline $\mathrm{PV}$ of public sector debt-to-revenue ratio (in percent) & 221.0 & 207.9 & 112.9 & 83.7 & 79.0 & 128.7 & 147.7 & 160.2 & 166.2 & 172.2 & 174.4 & 158.2 & 156.8 & 122.7 & 146.5 \\
\hline o/w external $3 /$ & 196.6 & 181.8 & 94.5 & 157.6 & 55.2 & 112.1 & 131.8 & 142.4 & 146.9 & 152.5 & 154.0 & 139.9 & 134.6 & 103.8 & 124.3 \\
\hline Debt service-to-revenue and grants ratio (in percent) 4/ & 4.8 & 4.8 & 3.5 & 7.6 & 3.3 & 4.9 & 4.0 & 4.9 & 6.6 & 7.7 & 9.0 & 6.2 & 8.8 & 7.3 & 8.5 \\
\hline Debt service-to-revenue ratio (in percent) $4 /$ & 7.6 & 7.6 & 5.4 & 12.4 & 5.5 & 7.3 & 6.0 & 7.3 & 9.8 & 11.2 & 13.1 & 9.1 & 11.8 & 8.9 & 11.2 \\
\hline Primary deficit that stabilizes the debt-to-GDP ratio & 34.1 & -1.7 & 1.2 & 11.2 & 19.9 & -1.7 & 2.5 & 2.8 & 3.1 & 1.8 & 2.4 & 1.8 & 3.6 & 3.2 & 3.4 \\
\hline \multicolumn{16}{|l|}{ Key macroeconomic and fiscal assumptions } \\
\hline Real GDP growth (in percent) & 7.3 & 6.7 & 6.3 & 8.0 & 2.0 & 6.5 & 7.5 & 7.6 & 7.9 & 7.8 & 7.8 & 7.5 & 7.2 & 7.5 & 7.3 \\
\hline Average nominal interest rate on forex debt (in percent) & 0.5 & 1.5 & 1.0 & 0.6 & 0.4 & 1.2 & 1.0 & 1.4 & 1.6 & 1.8 & 1.8 & 1.5 & 1.7 & 1.4 & 1.6 \\
\hline Average real interest rate on domestic debt (in percent) & 0.2 & 1.7 & 4.8 & 12.9 & 17.0 & 2.6 & 6.7 & 8.4 & 8.2 & 7.6 & $8.0^{\mathrm{r}}$ & 6.9 & 7.9 & $8.5^{\circ}$ & 8.3 \\
\hline Real exchange rate depreciation (in percent,+ indicates depreciation) & -10.4 & 13.2 & -1.7 & 0.1 & 12.8 & 2.7 & & & & & $\ldots$ & $\ldots$ & $\ldots$ & $\ldots$ & \\
\hline Inflation rate (GDP deflator, in percent) & 7.4 & 8.2 & 3.3 & 8.1 & 3.3 & 9.3 & 5.6 & 5.8 & 5.6 & 5.6 & 5.6 & 6.3 & 5.6 & 5.6 & 5.6 \\
\hline Growth of real primary spending (deflated by GDP deflator, in percent) & 0.1 & 0.1 & 0.3 & 0.1 & 0.1 & 0.0 & 0.2 & 0.1 & 0.1 & 0.1 & 0.1 & 0.1 & 0.1 & 0.1 & \\
\hline Grant element of new external borrowing (in percent) & & $\ldots$ & $\ldots$ & & & 39.0 & 23.4 & 24.8 & 26.3 & 29.6 & 30.9 & 29.0 & 34.4 & 35.9 & \\
\hline
\end{tabular}

Sources: Country authorities; and staff estimates and projections.

1/ Includes central government external PPG debt obligations and net domestic debt.

$2 /$ Gross financing need is defined as the primary deficit plus debt service plus the stock of short-term debt at the end of the last period.

3/ Revenues excluding grants.

f medium and long-term debt.

$5 /$ Historical averages and standard deviations are generally derived over years 2001-09, subject to data availability. 
Table 5.Mozambique: Sensitivity Analysis for Key Indicators of Public Debt 2010-2030

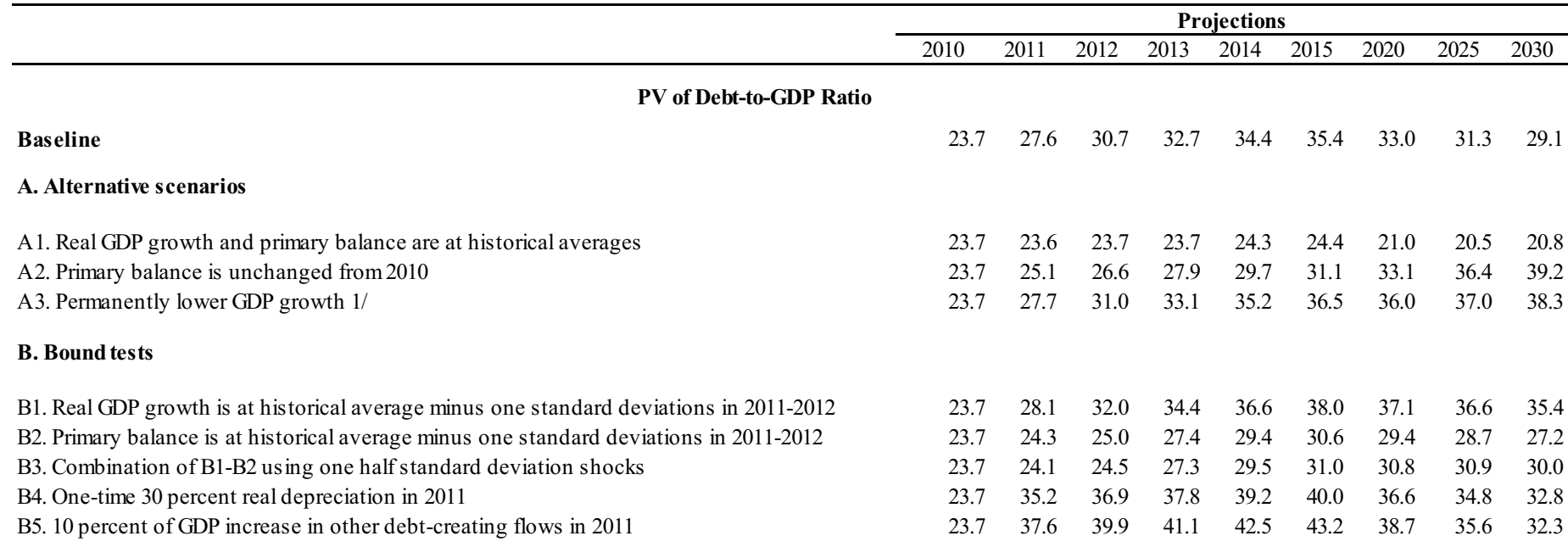

PV of Debt-to-Revenue Ratio 2/

\section{Baseline}

\section{A. Alternative scenarios}

A1. Real GDP growth and primary balance are at historical averages

A2. Primary balance is unchanged from 2010

A3. Permanently lower GDP growth 1/

\section{B. Bound tests}

B1. Real GDP growth is at historical average minus one standard deviations in 2011-2012

B2. Primary balance is at historical average minus one standard deviations in 2011-2012

B3. Combination of B1-B2 using one half standard deviation shocks

B4. One-time 30 percent real depreciation in 2011

B5. 10 percent of GDP increase in other debt-creating flows in 2011 $\begin{array}{lllllllll}87.2 & 98.2 & 108.0 & 113.2 & 118.1 & 120.2 & 116.1 & 110.0 & 100.5\end{array}$

$\begin{array}{rrrrrrrrr}87.2 & 83.9 & 83.1 & 82.1 & 83.1 & 82.7 & 74.0 & 72.3 & 71.9 \\ 87.2 & 89.3 & 93.4 & 96.5 & 101.9 & 105.6 & 116.3 & 127.8 & 135.1 \\ 87.2 & 98.5 & 108.8 & 114.6 & 120.3 & 123.3 & 125.9 & 129.1 & 131.0\end{array}$

$\begin{array}{rrrrrrrrr}87.2 & 99.6 & 111.7 & 118.2 & 124.5 & 128.0 & 129.7 & 128.0 & 121.8 \\ 87.2 & 86.4 & 87.9 & 95.0 & 100.9 & 103.9 & 103.6 & 100.7 & 93.8 \\ 87.2 & 85.4 & 86.0 & 94.2 & 100.9 & 104.8 & 108.2 & 108.2 & 103.4 \\ 87.2 & 125.1 & 129.9 & 130.9 & 134.3 & 135.5 & 128.6 & 122.2 & 113.2 \\ 87.2 & 133.7 & 140.2 & 142.3 & 145.7 & 146.4 & 136.3 & 124.9 & 111.3\end{array}$

Debt Service-to-Revenue Ratio 2/ $\begin{array}{lllllllll}4.9 & 4.0 & 4.9 & 6.6 & 7.7 & 9.0 & 8.8 & 8.2 & 7.3\end{array}$

\section{A. Alternative scenarios}

A1. Real GDP growth and primary balance are at historical averages

A2. Primary balance is unchanged from 2010

A3. Permanently lower GDP growth 1/

\section{B. Bound tests}

B1. Real GDP growth is at historical average minus one standard deviations in 2011-2012

B2. Primary balance is at historical average minus one standard deviations in 2011-2012

B3. Combination of B1-B2 using one half standard deviation shocks

B4. One-time 30 percent real depreciation in 2011

B5. 10 percent of GDP increase in other debt-creating flows in 2011

$\begin{array}{lllllllll}4.9 & 4.0 & 4.4 & 5.7 & 6.5 & 7.7 & 7.2 & 5.5 & 4.8\end{array}$

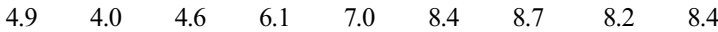

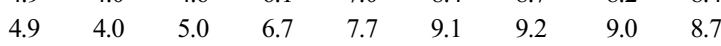

Sources: Country authorities; and staff estimates and projections.

1/ Assumes that real GDP growth is at baseline minus one standard deviation divided by the square root of the length of the projection period.

2/ Revenues are defined inclusive of grants. 
Figure 2. Mozambique: Indicators of Public Debt Under Alternative Scenarios, 2010-2030 1/
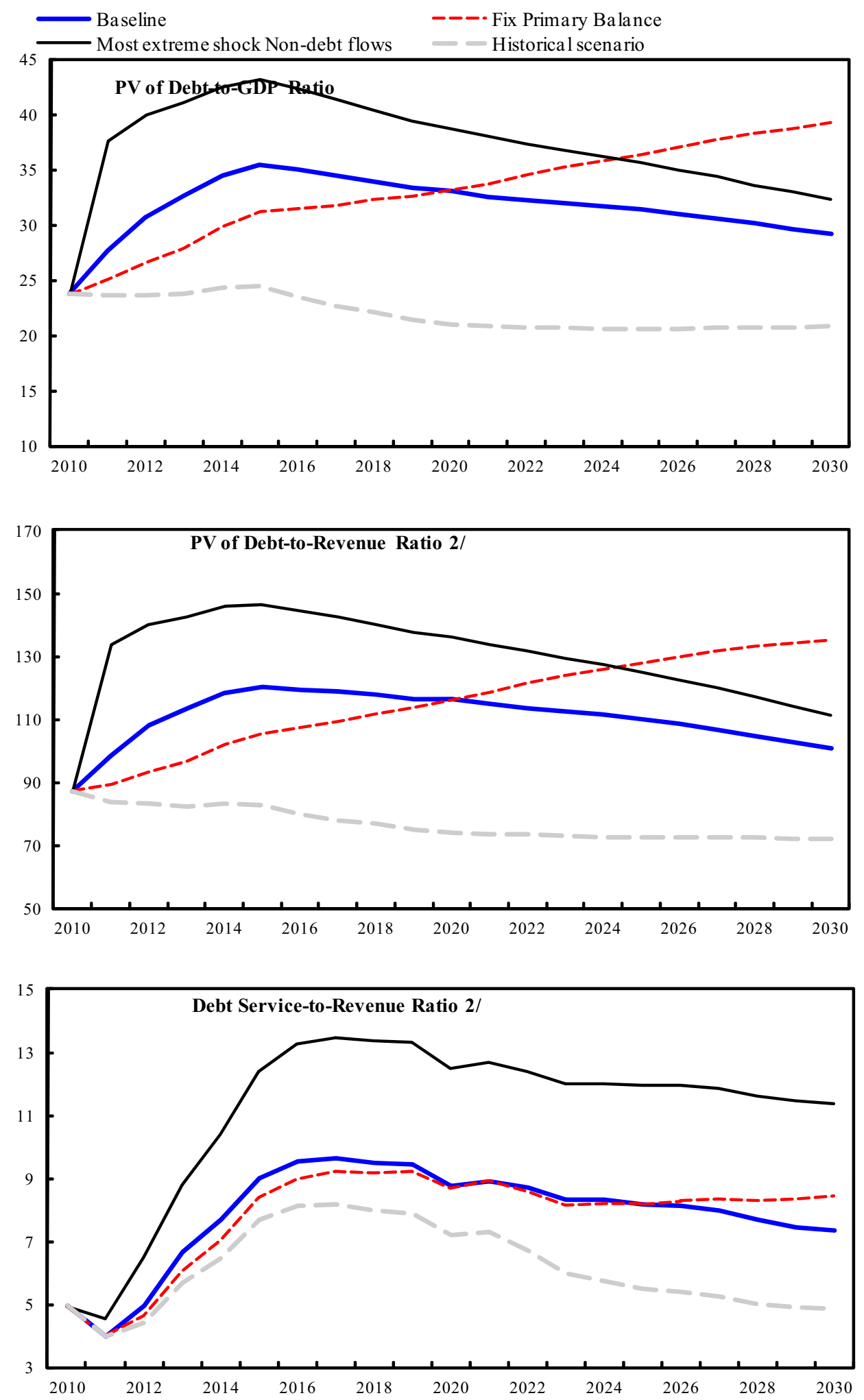

Sources: Country authorities; and staff estimates and projections.

1/ The most extreme stress test is the test that yields the highest ratio in 2020.

2/ Revenues are defined inclusive of grants. 


\title{
INTERNATIONAL MONETARY FUND
}

\section{REPUBLIC OF MOZAMBIQUE}

\section{Sixth Review Under the Policy Support Instrument, Second Review Under the Arrangement Under the Exogenous Shocks Facility, and Request for a Three-Year Policy Support Instrument- Informational Annex}

\author{
Prepared by the African Department \\ (In consultation with other departments)
}

May 27, 2010

I. Relations with the Fund ......................................................................................

II. World Bank-IMF Joint Management Action Plan ................................................

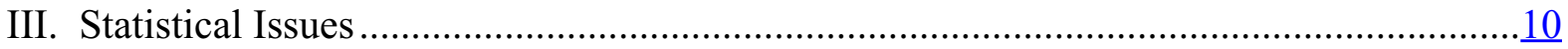




\section{MoZAmbiQUe: Relations With THE FUND}

(as of April 30, 2010)

I. Membership Status: Joined: September 24, 1984;

Article XIV

II. General Resources Account:

SDR Million

\%Quota

Quota

113.60

100.00

Fund holdings of currency

113.60

100.00

Reserve Position

0.01

0.01

III. SDR Department:

SDR Million

\%Allocation

108.84

100.00

Net cumulative allocation

108.66

99.83

Holdings

SDR Million

99.40

9.74
\%Quota

87.50

8.57

ECF Arrangements

\begin{tabular}{|c|c|c|}
\hline Type & $\begin{array}{c}\text { Date of } \\
\text { Arrangement }\end{array}$ & $\begin{array}{c}\text { Expiration } \\
\text { Date }\end{array}$ \\
\hline $\mathrm{ESF}$ & Jun 30,2009 & Jun $29, \overline{2010}$ \\
\hline $\mathrm{ECF}^{1}$ & Jul 06, 2004 & Jul 05, 2007 \\
\hline $\mathrm{ECF}^{1}$ & Jun 28, 1999 & Jun 28, 2003 \\
\hline
\end{tabular}

${ }^{1}$ Formerly PRGF.

VI. Projected Payments to Fund ${ }^{2}$

(SDR Million; based on existing use of resources and present holdings of SDRs):

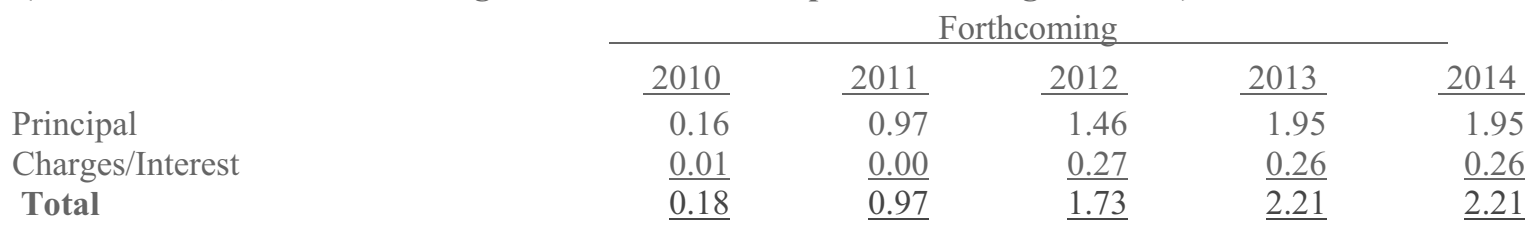

${ }^{2}$ When a member has overdue financial obligations outstanding for more than three months, the amount of such arrears will be shown in this section. 
VII. Implementation of HIPC Initiative:

I. Commitment of HIPC assistance

Decision point date

\begin{tabular}{|c|c|}
\hline Original & Enhanced \\
\hline ramework & Framework \\
\hline Apr 1998 & Apr 2000 \\
\hline $1,716.00$ & 306.00 \\
\hline 124.60 & 18.46 \\
\hline 93.17 & 13.73 \\
\hline
\end{tabular}

Assistance committed

by all creditors (US\$ Million) ${ }^{1}$

Of which: IMF assistance (US\$ million)

(SDR equivalent in millions)

Jun. 1999 Sep. 2001

Completion point date

II. Disbursement of IMF assistance (SDR Million)

Assistance disbursed to the member

$\begin{array}{rrr}93.17 & 13.73 & 106.90 \\ -- & 2.31 & 2.31 \\ 93.17 & 11.42 & 104.58 \\ -- & 1.10 & 1.10 \\ 93.17 & 14.83 & 108.00\end{array}$

Interim assistance

Completion point balance

Additional disbursement of interest income ${ }^{2}$

Total disbursements

93.17

14.83

Total

\footnotetext{
${ }^{1}$ Assistance committed under the original framework is expressed in net present value (NPV) terms at the completion point, and assistance committed under the enhanced framework is expressed in NPV terms at the decision point. Hence these two amounts can not be added.

${ }^{2}$ Under the enhanced framework, an additional disbursement is made at the completion point corresponding to interest income earned on the amount committed at the decision point but not disbursed during the interim period.
}

\section{Implementation of Multilateral Debt Relief Initiative (MDRI):}

I. $\quad$ MDRI-eligible debt (SDR Million) ${ }^{1} \quad 106.56$

Financed by: MDRI Trust $\quad 83.05$

Remaining HIPC resources $\quad 23.51$

II. Debt Relief by Facility (SDR Million)

\section{Eligible Debt}

$\begin{array}{lrrr}\text { Delivery Date } & \underline{\text { GRA }} & \underline{\text { PRGF }} & \underline{\text { Total }} \\ \text { January } 2006 & \text { N/A } & 106.56 & 106.56\end{array}$

${ }^{1}$ The MDRI provides 100 percent debt relief to eligible member countries qualified for the assistance. Grant assistance from the MDRI Trust and HIPC resources provide debt relief to cover the full stock of debt owed to the Fund as of end-2004 outstanding at the time the member qualifies for debt relief. 


\section{Safeguards assessment}

An update safeguards assessment of the Bank of Mozambique's (BM) was completed on January 11, 2010 for the ESF. The assessment found improvements in financial reporting practices following the implementation of IFRS. It noted vulnerabilities in the oversight mechanism for external and internal auditing, controls, financial reporting, and in BM legal structure. It recommended that the BM commission an external quality assurance review of the internal audit function. Staff will follow-up on progress in implementing the assessment's recommendations.

\section{Exchange arrangements}

Mozambique has a floating exchange system. Commercial banks may buy and sell foreign exchange to individual customers on a fully negotiable basis. The Bank of Mozambique introduced a foreign exchange auction system in January 2005. Foreign exchange transactions are conducted mainly bilaterally and there is no pre-established frequency for auctions.

Mozambique still avails itself of the transitional arrangements under Article XIV of the Fund Articles of Agreement, but has eliminated all Article XIV restrictions. It maintains, however, restrictions on the making of payments and transfers for current international transactions subject to Fund approval under Article VIII, as evidenced by: (i) the discretionary prior approval for remittances of family living expenses; (ii) the authorization for the purchase of foreign exchange in excess of US $\$ 5,000$ for certain transactions; (iii) the prohibition for the conversion of balances of nonresidents' domestic currency accounts into foreign currency or transfer abroad; (iv) the prohibition on advance payments for a service; and (v) the prohibition on advance payments for the import of goods. At the authorities' request, an Article VIII mission was conducted by LEG and PDR in March 2004. A new foreign exchange law was submitted to the Assembly in May 2007 and came into effect on March 11,2009 . Following issuance of implementation regulations, the authorities intend to accept their obligations under Article VIII sections 2, 3, and 4 of the Fund's Articles of Agreement.

\section{Article IV consultation}

In accordance with Decision No 12794-(02/76), as amended by Decision No 12854-(02/96), Mozambique is on a 24-month Article IV cycle due to the approval of a PSI in June 2007. The 2009 Article IV consultation was completed by the Executive Board on June 30, 2009 (Country Report No. 09/227).

In concluding the 2009 Article IV consultation, Executive Directors welcomed Mozambique's continued strong macroeconomic performance in 2008 despite a challenging external environment. They commended the authorities' flexible policy response to higher fuel and food import prices, which helped to mitigate the impact of these shocks. Directors noted that Mozambique remains vulnerable to the global economic slowdown and agreed that 
the country's strong track record of prudent macroeconomic policy implementation has provided room to ease fiscal and monetary policy in the near term. In the medium term, Directors underscored the importance of preserving macroeconomic stability and supported efforts to enhance domestic revenue mobilization and to improve public financial management. They welcomed the authorities' intention to limit recourse to domestic financing of the budget so as to preserve sufficient room for private sector credit growth. With respect to the overvaluation of the exchange rate in real effective terms, Directors suggested paying closer attention to a basket of currencies, which could help support Mozambique's competitiveness and economic diversification. Further progress in structural reforms and in developing and safeguarding the soundness of the banking system were seen as instrumental in supporting the business environment.

\section{Ex post assessment of performance under Fund-supported programs}

An ex post assessment (EPA) of Mozambique's performance under Fund-Supported Programs since 1987 was undertaken in December 2003 under the guidelines on assessments of countries with a longer-term program engagement. The EPA was circulated to the Executive Board on November 21, 2003 (Country Report No. 04/53).

Directors commended the authorities for their pursuit of sound macroeconomic policies and wide ranging structural reforms over the past fifteen years which contributed to strong growth of the economy, and a steady decline in poverty rates. Noting that despite considerable progress Mozambique remains a very poor and vulnerable country, Directors urged the authorities to persevere in their efforts to consolidate macroeconomic stability and accelerate and deepen structural reforms with a view to sustaining economic growth, encouraging employment creation, and further reducing poverty.

\section{FSAP participation and ROSCs}

A Financial Sector Assessment Program (FSAP) for Mozambique was undertaken during the first quarter of 2003. The related Financial Sector Stability Assessment was circulated to the Executive Board on November 19, 2003 (Country Report No. 04/52). An update to the FSAP took place in February 2009 and the related Financial Sector Stability Assessment circulated to the Board on June 19, 2009 (Country Report No. 10/12) A ROSC on fiscal transparency was issued on February 22, 2001. This ROSC was updated in the context of the 2002 Article IV consultation (Country Report No. 02/140) and the 2003 Article IV Consultation (Country Report No. 04/50). The ROSC on fiscal transparency was updated in May 2008. A Report on the Observance of Standards and Codes (ROSC) data module was prepared in June 2002 and issued on March 5, 2003. This data module was updated in August 2005. 


\section{Management's visit}

At the invitation of the authorities, Mr. Kato, Deputy Managing Director, visited Maputo, Mozambique in July 2005.The Managing Director visited Mozambique on August 2007 for a meeting with the African Consultative Group on Quotas, Voice, and Representation.

\section{Resident representative}

Mr. Felix Fischer has been the IMF's resident representative to Mozambique since March 14, 2006. 


\begin{tabular}{|c|c|c|c|c|}
\hline \multicolumn{5}{|c|}{$\begin{array}{l}\text { IMF Technical Assistance Provided to Mozambique } \\
\qquad(2006-10)\end{array}$} \\
\hline Departments & Timing & Form & Purpose & Counterparts \\
\hline Finance & February 2008 & Mission & Update of Safeguard Assessment & $\begin{array}{l}\text { Bank of } \\
\text { Mozambique }\end{array}$ \\
\hline \multirow[t]{14}{*}{ Fiscal Affairs } & April-May 2010 & Mission & Revenue Administration Reform & Ministry of Finance \\
\hline & April 2010 & Mission & $\begin{array}{l}\text { Public Financial Management } \\
\text { Reforms }\end{array}$ & Ministry of Finance \\
\hline & February 2010 & Mission & Tax Policy Review & Ministry of Finance \\
\hline & May 2009 & Mission & Tax Administration Reform & Ministry of Finance \\
\hline & April 2008 & Mission & $\begin{array}{l}\text { Public Financial Management } \\
\text { Reforms }\end{array}$ & Ministry of Finance \\
\hline & April-May 2008 & Mission & Revenue Administration Reform & Ministry of Finance \\
\hline & Oct.-Nov. 2007 & Mission & Tax Administration Inspection & Ministry of Finance \\
\hline & September 2007 & Mission & $\begin{array}{l}\text { Public Private Partnerships and } \\
\text { Fiscal Risks }\end{array}$ & Ministry of Finance \\
\hline & August 2007 & Peripatetic expert & Tax Policy and Administration & Ministry of Finance \\
\hline & August 2007 & Mission & $\begin{array}{l}\text { Fiscal ROSC Update and Public } \\
\text { Financial Management inspection }\end{array}$ & Ministry of Finance \\
\hline & April-May 2007 & Mission & Tax Administration Inspection & Ministry of Finance \\
\hline & April-May 2007 & Mission & Petroleum Fiscal Regime & $\begin{array}{l}\text { Ministry of Finance } \\
\text { Ministry of Mineral } \\
\text { Resources }\end{array}$ \\
\hline & December 2006 & Mission & Tax Administration & Ministry of Finance \\
\hline & March 2006 & Mission & Tax Policy Review & Ministry of Finance \\
\hline \multirow[t]{6}{*}{$\begin{array}{l}\text { Monetary and } \\
\text { Capital Markets }\end{array}$} & April 2010 & Mission & $\begin{array}{l}\text { Strengthening Monetary Policy } \\
\text { Formulation and Implementation }\end{array}$ & $\begin{array}{l}\text { Bank of } \\
\text { Mozambique }\end{array}$ \\
\hline & November 2009 & Mission & $\begin{array}{l}\text { Strengthening Monetary Policy } \\
\text { Formulation and Implementation }\end{array}$ & $\begin{array}{l}\text { Bank of } \\
\text { Mozambique }\end{array}$ \\
\hline & May 2009 & Mission & 2009 FSAP Follow up & $\begin{array}{l}\text { Bank of } \\
\text { Mozambique }\end{array}$ \\
\hline & February 2009 & Mission & $\begin{array}{l}\text { TA on Central Banking and } \\
\text { Monetary Policy Formulation }\end{array}$ & $\begin{array}{l}\text { Bank of } \\
\text { Mozambique }\end{array}$ \\
\hline & May 2008 & Mission & $\begin{array}{l}\text { Strengthening Monetary Policy } \\
\text { Formulation and Implementation }\end{array}$ & $\begin{array}{l}\text { Bank of } \\
\text { Mozambique }\end{array}$ \\
\hline & December 2007 & Mission & $\begin{array}{l}\text { Implementation of IFRS for } \\
\text { Central Bank Accounts. }\end{array}$ & $\begin{array}{l}\text { Bank of } \\
\text { Mozambique }\end{array}$ \\
\hline
\end{tabular}




\begin{tabular}{|c|c|c|c|c|}
\hline \multicolumn{5}{|c|}{$\begin{array}{l}\text { IMF Technical Assistance Provided to Mozambique } \\
\qquad(2006-10)\end{array}$} \\
\hline \multirow[t]{8}{*}{ Departments } & Timing & Form & Purpose & Counterparts \\
\hline & August 2007 & Mission & $\begin{array}{l}\text { Post-FSAP TA Assessment: } \\
\text { Banking supervision, Monetary } \\
\text { Policy and Operations }\end{array}$ & $\begin{array}{l}\text { Bank of } \\
\text { Mozambique }\end{array}$ \\
\hline & April 2007 & Short-term consultant & Banking Supervision & $\begin{array}{l}\text { Bank of } \\
\text { Mozambique }\end{array}$ \\
\hline & October 2006 & Mission & $\begin{array}{l}\text { Post-FSAP TA Assessment: } \\
\text { Banking supervision, Monetary } \\
\text { Policy and Operations }\end{array}$ & $\begin{array}{l}\text { Bank of } \\
\text { Mozambique }\end{array}$ \\
\hline & Feb-March 2006 & Mission & AML/CFT legislation & $\begin{array}{l}\text { Bank of } \\
\text { Mozambique }\end{array}$ \\
\hline & Jan-Feb 2006 & Short-term consultant & Monetary Policy Framework & $\begin{array}{l}\text { Bank of } \\
\text { Mozambique }\end{array}$ \\
\hline & Jan-Feb 2006 & Short-term consultant & Monetary Operations & $\begin{array}{l}\text { Bank of } \\
\text { Mozambique }\end{array}$ \\
\hline & January 2006 & Short-term consultant & Exchange Rate Management & $\begin{array}{l}\text { Bank of } \\
\text { Mozambique }\end{array}$ \\
\hline \multirow[t]{8}{*}{ Statistics } & February 2010 & Mission & Multitopic GDDS & $\begin{array}{l}\text { National Institute of } \\
\text { Statistics }\end{array}$ \\
\hline & $\begin{array}{l}\text { March-April } \\
2008\end{array}$ & Mission & National Accounts Statistics & $\begin{array}{l}\text { National Institute of } \\
\text { Statistics }\end{array}$ \\
\hline & February 2008 & Mission & Balance of Payments Statistics & $\begin{array}{l}\text { Bank of } \\
\text { Mozambique }\end{array}$ \\
\hline & December 2007 & Mission & Balance of Payments Statistics & $\begin{array}{l}\text { Bank of } \\
\text { Mozambique }\end{array}$ \\
\hline & November 2007 & Mission & Monetary and Financial Statistics & $\begin{array}{l}\text { Bank of } \\
\text { Mozambique }\end{array}$ \\
\hline & June-July 2006 & Mission & Consumer Price Statistics & $\begin{array}{l}\text { National Institute of } \\
\text { Statistics (INE) }\end{array}$ \\
\hline & $\begin{array}{l}\text { August } 2005- \\
\text { July } 2006\end{array}$ & Long-term consultant & National Accounts Statistics & $\begin{array}{l}\text { National Institute of } \\
\text { Statistics }\end{array}$ \\
\hline & July 2005 & Mission & Government Finance Statistics & $\begin{array}{l}\text { National Institute of } \\
\text { Statistics }\end{array}$ \\
\hline
\end{tabular}




\section{World Bank-IMF JoInt Management ACtion Plan}

\section{Mozambique: World Bank-IF Joint Management Action Plan}

\section{Title}

Products

A. Mutual information on relevant work

program in next 12 months

Bank work program

Updated poverty analysis using the 2008/09 household survey

August 2010

FSTAP project support to financial sector reforms

Ongoing

Financial Sector Strategy

TBC

Financial Sector Contingency Plan

TBC

Fund work program

First PSI Review

Second PSI Review and 2011 Article IV

September 2010

March 2011

December 2010

June 2011

\section{B. Requests for work program inputs with} summary justification

Bank request to the Fund

Fund request to the Bank

Updated Macro Framework data

PSI reviews

Board Chairman Summing up from PSI review discussion (or Assessment letter) not older than six-months

Updates on advancing structural reforms: procurement, decentralization, business environment, financial sector

October 2010, April 2011

October 2010, January 2011

June 2010 to June 2011

$\begin{array}{ll}\text { March } 2010 & \text { June } 2010 \\ \text { TBD } & \text { Sep-10 } \\ \text { TBD } & \text { November } 2010 \\ \text { TBD } & \text { October } 2010\end{array}$

PFM: update work plan for 2009-11 in light of findings from PEFA TBD and ROSC

PFM: continue to monitor consolidation and expansion of e- Ongoing

Ongoing SISTAFE.

Policy advice on Public Sector Salary Reforms (incl. pensions)

Ongoing 


\section{Mozambique: Statistical Issues}

\section{Assessment of Data Adequacy for Surveillance}

General: Data provision has some shortcomings, but is broadly adequate for surveillance. Despite the increase in budget resources allocated to the compilation of official statistics, continued high reliance on external funding raises concerns about the sustainability of the programs of the National Institute of Statistics (INE). The authorities are making efforts to improve the quality and timeliness of economic and financial data through participation in the Fund's General Data Dissemination System (GDDS) and in the external sector module of the GDDS Project for Anglophone African Countries (funded by the U.K. Department for International Development (DFID)). Weaknesses exist, particularly in the areas of national accounts, prices, and government finance statistics.

Real sector statistics: The national accounts are prepared by the INE in accordance with the 1993 System of National Accounts (1993 SNA). In August 2007, the INE released quarterly GDP estimates at constant prices covering 2000-07 for the first time, along with a revised annual GDP series for the period 1991-2006, with 2003 as the new base year. The authorities are working to strengthen quarterly national accounts compilation at current prices. The INE's new household income and expenditure survey and economic censuses leading to a new business registry still need to be incorporated to strengthen the national accounts. A revamped consumer price index for Maputo based on weights derived from the 2002-03 household survey was released in February 2006. A national index obtained by integrating the indices for Maputo, Beira, and Nampula was released in April 2006. Several issues remain outstanding, however, to correct probable downward bias caused by carry forward techniques for discontinued products, improve the housing market rent sample, and expand coverage to include Quelimane and Greater Maputo areas. There are insufficient sectoral labor market and employment data, and where available, they have limited coverage. A one-year labor market survey of the entire country, undertaken by INE in collaboration with the Labor Ministry, was launched in October 2004.

Government finance statistics: Government finance statistics (GFS) are not compiled using an internationally accepted statistical methodology and no staff has been identified to do so. A complete list of public sector entities is lacking. Work on a correspondence table between budgetary information and GFS needs to be completed. In addition, work on an integrated information system to capture completely stocks and flow information needs further development.

Monetary and financial statistics: A 2004 work plan was developed to implement the Monetary and Financial Statistics Manual (MFSM) and develop an integrated monetary database (IMD) to meet the needs of the Bank of Mozambique (BM), AFR, and STA. In 
November 2007 the IMD was completed and allows the derivation of accurate and timely monthly monetary statistics, while reducing BM's reporting burden.

Balance of payments: With assistance from STA, provided in the context of the GDDS regional project, the $\mathrm{BM}$ has made significant progress toward compiling and disseminating balance of payments (BOP) and international investment position (IIP) statistics that are fully aligned with the Balance of Payments Manual, fifth edition (BPM5). The BM has an adequate institutional framework for the compilation of BOP and IIP statistics. However, further strengthening of external sector statistics needs to focus on: strengthening information technology (especially to apply data warehouse and on-line analytical processing tools); excluding the effects of price and exchange rate fluctuations from reserve asset flows; applying a methodology (provided through STA technical assistance) to estimate reinvested profits and stocks of financial assets and liabilities held abroad by the nonfinancial public sector; improving business surveys; publishing methodological notes, in general, and more data covering the Reserves Template, foreign direct investment, goods trade and current transfers; and beginning the gradual process to implement the new Balance of Payments and International Investment Position Manual, sixth edition. Joint work with other institutions to improve the quality of external trade data, especially with regard to price and volume indices, also merits attention.

\section{Data Standards and Quality}

Mozambique commenced its participation in the General Data Dissemination System (GDDS) in November 2003; but has since then not updated much of its metadata.

In May 2005, an update of the June 2002 data module of the Report on the Observance of Standards and Codes (Data ROSC) was prepared. Improvements in the institutional environment and increased allocation of resources for the compilation of national accounts and balance of payments statistics aimed to address weaknesses in the prerequisites for the quality of the statistics. Methodological soundness, accuracy, and reliability of macroeconomic statistics began to show improvements as a result of these efforts.

\section{Reporting to STA}

Mozambique does not report fiscal data for publication in the IFS or the Government Finance Statistic Yearbook (GFSY). Mozambique now reports monthly monetary data to STA using the standardized reporting forms (SRFs). As a result, these enhanced data are being published in the International Financial Statistics (IFS) Supplement. In 2007, the BM started to compile and report comprehensive IIP data in the Balance of Payments Statistics Yearbook. 
Mozambique: Table of Common Indicators Required for Surveillance

(As of May 10, 2010)

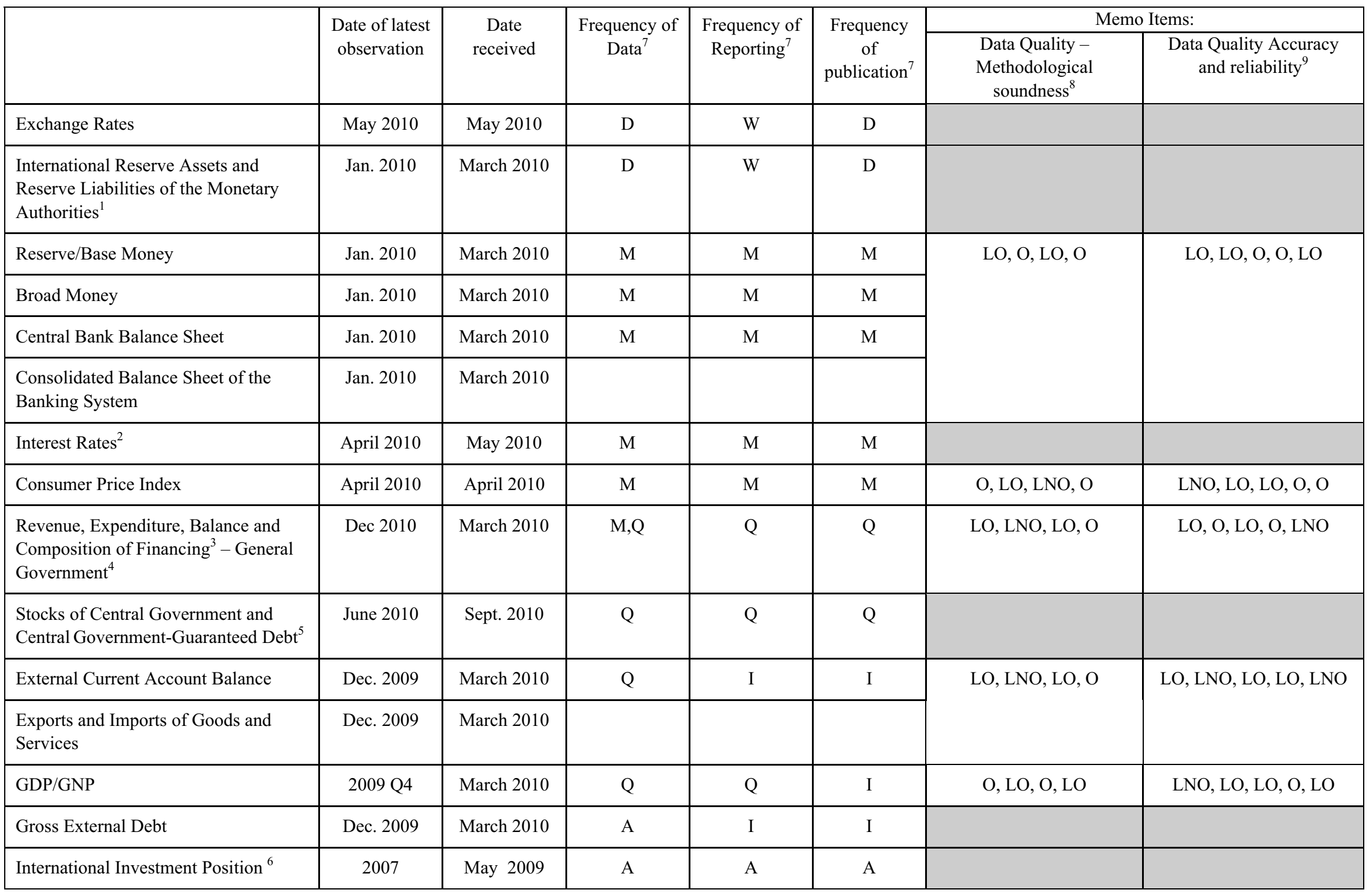

${ }^{1}$ Includes reserve assets pledged or otherwise encumbered as well as net derivative positions.

${ }^{2}$ Both market-based and officially determined, including discount rates, money market rates, rates on treasury bills, notes and bonds.

${ }^{3}$ Foreign, domestic bank, and domestic nonbank financing.

${ }^{4}$ The general government consists of the central government (budgetary funds, extrabudgetary funds, and social security funds) and state and local governments.

${ }^{5}$ Including currency and maturity composition.

${ }^{6}$ Includes external gross financial asset and liability positions vis-àvis nonresidents.

${ }^{7}$ Includes external gross financial asset and liability positions vis-àvis nonresidents.

${ }^{8}$ Daily (D), Weekly (W), Monthly (M), Quarterly (Q), Annually (A), and Not Available (NA)

${ }^{9}$ Reflects the assessment provided in the data ROSC or the Substantive Update for the dataset corresponding to the variable in each row. The assessment indicates whether international standards concerning concepts and definitions,

scope, classification/sectorization, and basis for recording are fully observed (O); largely observed (LO); largely not observed (LNO); not observed (NO); and not available (NA). 


\section{IMF Executive Board Approves New Three-Year PSI, Completes Second Review Under the ESF Arrangement and Approves US\$21 Million Disbursement for Mozambique}

The Executive Board of the International Monetary Fund (IMF) today completed the sixth and final review of Mozambique's economic performance under the Policy Support Instrument (PSI) and approved a new threeyear PSI.

The Board also completed the second review of Mozambique's performance under the Exogenous Shocks Facility (ESF), which will enable the third and final disbursement of SDR 14.2 million (about US\$21 million). The one-year, SDR 113.6 million (about US\$176 Million) ESF arrangement was approved on June 30, 2009 (see Press Release No. 09/247).

In completing the reviews, the Executive Board granted a waiver for the nonobservance of the end-December 2009 assessment criterion on the ceiling on reserve money.

The new PSI for Mozambique aims at accelerating economic development and reducing poverty while maintaining macroeconomic stability. The authorities aim to meet their development needs through a significant stepping up of public investment in infrastructure, which would necessitate broadening the financing options to also include nonconcessional borrowing.

The IMF's framework for PSIs is designed for low-income countries that may not need, or want, IMF financial assistance, but still seek IMF advice, monitoring, and endorsement of their policies. (see Public Information Notice No. 05/145). The previous PSI for Mozambique was approved by the Executive Board on June 18, 2007 (See Press Release No. 07/135).

Following the Executive Board's discussion on Mozambique, Mr. Murilo Portugal, Deputy Managing Director and Acting Chair, stated:

“Mozambique's macroeconomic performance in 2009 was resilient to the global economic crisis. Economic growth was stronger than envisaged and inflation remained low. The authorities' strong track record of prudent policy implementation provided the necessary room for policy easing, which helped mitigate the impact of the crisis. With the improved economic outlook, the authorities plan to start unwinding the policy easing in 2010. Significant headway was made in implementing key structural reforms, especially measures related to public financial management, tax policy and administration, the monetary policy framework, and financial sector supervision.

"Policies under the successor PSI will focus on enhancing economic growth to help Mozambique meet its development objectives while safeguarding macroeconomic stability. Embedded in a prudent fiscal and monetary policy stance, the PSI will support a sizeable increase in public sector investment, which will focus on, among others, the energy and transportation sectors, partially financed by nonconcessional external borrowing. Together with measures to improve the business environment, this is expected to help remove identified bottlenecks, so that the private sector can develop and play its intended role as an engine of growth. 
"The structural reform program emphasizes the need to make prudent and effective public investment and borrowing decisions. To this end, it focuses on strengthening the framework for investment planning and formulating and implementing a comprehensive debt strategy. The structural reform agenda will also continue to place emphasis on measures to strengthen public financial management, tax policy and administration, and the Bank of Mozambique's liquidity forecasting and management," Mr. Portugal added. 
ANNEX

\section{Recent Economic Developments}

Mozambique showed considerable resilience to the global crisis. Real GDP grew by $6 \frac{1}{3}$ percent in 2009, more than expected, owing to stronger performance of the construction, energy, and financial sectors. Large declines occurred in export receipts and private capital inflows, but the impact on external reserves was mitigated by the SDR allocation and by resources provided by the IMF through the Exogenous Shocks Facility.

As the global economy recovers, the economic outlook is expected to become more favorable. Real GDP growth should increase to $6 \frac{1}{2}$ percent in 2010 and 73aercent by 2013, largely because of new megaprojects in the natural resource sector, stepped-up public investment, and larger private sector participation. Continued prudent macroeconomic policies should keep inflation at around 6 percent on average over the medium-term, with a temporary spike in 2010 to above 9 percent following the gradual removal of the fuel subsidy. The government's investment plans should not fundamentally burden the external current account deficit and reserve levels. The current account deficit (after grants) and international reserves are expected to hover around 13 percent of GDP and above five months of imports over the next three years.

\section{Program Summary}

Mozambique's PSI aims at creating an environment conducive to strong growth, which is expected to also help ensure that more and more segments of the population will benefit from economic development. It envisages a limited expansion of nonconcessional external borrowing and domestic financing to boost infrastructure investment while maintaining a prudent fiscal policy stance that would keep the primary domestic deficit broadly unchanged. Monetary policy will be sufficiently tight to keep domestic demand pressures in check while providing ample room for private sector credit expansion.

Structural reforms will focus on improving the authorities' capacity for informed decision making, by promoting debt management, developing a borrowing strategy, and improving investment planning. It will also be important to continue the ongoing reforms with respect to public financial management, tax policy and administration, the monetary policy framework, and financial sector supervision.

The authorities' program will support an updated Poverty Reduction Strategy, which will be drafted involving with the private sector, civil society, and development partners, and finalized in the second half of 2010. 


\section{Statement by Moeketsi Majoro, Alternate Executive Director for Republic of Mozambique}

June 14, 2010

\section{Introduction}

1. My Mozambican authorities value the continued support by the Fund and the constructive policy dialogue with staff. They are committed to implementing reforms and to macroeconomic stability, as is evidenced by the overall satisfactory performance under the current PSI arrangement since its inception, and plan to further strengthen their engagement with the Fund under the successor PSI arrangement, for which they request approval by the Executive Directors.

2. With respect to the current program, all quantitative assessment/performance criteria through end-December 2009 were met, except for the one on reserve money, for which the authorities request a waiver. Reserve money exceeded the program ceiling because of the continued difficulty in predicting the demand for currency in circulation as a result of both the year-end seasonal surge and the structural shift from the expansion of banking services in the economy. In addition, there was progress in implementing structural reforms. In this regard, the authorities request Directors' support for the completion of the sixth review under the PSI and the second review under the ESF.

\section{Performance in 2009}

3. Mozambique has showed considerable resilience to the global economic crisis. Real GDP growth was much stronger than expected in 2009, which has been supported by construction, energy, and financial sectors. The global economic downturn triggered a large decline in export receipts and private external borrowing. The impact on external reserves was, however, mitigated by the SDR allocation and ESF resources, resulting in reserve coverage above 5 months of imports. The Government eased macroeconomic policies to contain spillover effects of the global crisis to the domestic economy. An accommodating monetary policy facilitated the substitution of foreign borrowing with a strong domestic private sector credit expansion. On the fiscal side, revenue performance kept the size of the automatic stabilizers small and resulted in a lower-than-expected domestic primary fiscal deficit.

\section{Objectives and policies under the new successor PSI arrangement and outlook}

\section{Objectives and outlook}

4. Economic performance has been strong and policy implementation has been successful under successive IMF-supported programs. Despite the relative strong GDP 
growth of the past decade, there are concerns that even though capital-intensive export sectors are growing, activity in the rest of the economy is below potential and labor-intensive growth is yet to be meaningfully exploited. In addition, although economic growth in Mozambique is high by regional standards, it has been trending down over the last few years. This slowed down progress in reducing poverty and improving development indicators. In this context, the authorities recognize the necessity of enhancing their efforts to sustainably raise and broaden the country's productive base.

5. Going forward, the authorities' focus will be on implementing policies to facilitate private sector development and sustainable economic growth. To that end, steps will be to enhance economic growth and rural development, in particular, with impact on the poor and disadvantaged through the creation and expansion of jobs; and acceleration of measures to improve the business environment and support to small and medium-sized enterprises. They will also seek to improve the selection process and prioritization of public investment in order to maximize the benefits associated with employment creation and poverty reduction and crowd-in private sector investment and production; and, further strengthen institutions to enable them reap the benefits from regional integration.

6. Consistent with these objectives and policies, and taking into account the political cycle in Mozambique, the Parliament has recently approved the Government's Five-Year Government Program for 2010-14. This program will be supplemented by an updated Poverty Reduction Strategy, which will be drafted, in a consultative process with all stakeholders, and finalized in the second half of 2010, taking into account the publication of the results of the Household Survey.

7. The economic outlook is expected to improve, as the global economic crisis wanes. Real GDP growth should accelerate to $6 \frac{1}{2}$ pecent in 2010 and above 7 percent by 2013 , facilitated largely by new megaprojects, stepped-up public investment in areas with an expected large growth dividend, and larger private sector participation. Continued prudent macroeconomic policies should keep inflation low over the medium-term, with a temporary spike in 2010 following the gradual removal of the fuel subsidy. Since the publication of the staff report, another fuel price increase has taken place, in line with program commitments. The authorities' investment plans are not anticipated to fundamentally burden the current account and, as a result, international reserve levels are expected to remain above 5 months of imports over the next three years.

8. The authorities are very thankful for the staff's collaboration at a Seminar held in Namaacha — south of Mozambique — to discuss Mozambique's medium-term economic policy priorities, as well as on the identification of options for financing the country's public investment program. This was a unique setting in terms of a wide participation of relevant decision-making individuals from the public sector and other stakeholders in the country. The authorities appreciate the fact that staff took time to participate in this retreat and to engage openly on policy options and exchange ideas, outside the normal review mission 
meetings.

\section{Fiscal policy}

9. The authorities aim to reduce the domestic primary deficit to 4.2 percent of GDP, in 2010. This will be attained through further improvements in the tax administration and current expenditure restraint. The 2010 budget law anticipates strong efficiency gains in tax administration that could boost the revenue-to-GDP ratio to $183 / 4$ percent of GDP. Furthermore, the authorities will base the budget execution on more conservative assumptions.

10. The authorities plan to step-up implementation of public investments in transport and electricity infrastructure by tapping domestic and international financing. They also plan to limit their annual recourse to domestic financing to less than 1 percent of GDP over the medium term. This would avoid crowding out the private sector. Concessional donor funding will remain the prime sources of financing in the foreseeable future. Nonetheless, given the size of the planned investment plans, the authorities are considering external nonconcessional borrowing averaging about 2 $\frac{1}{2}$ percent of GDP per year during the next three years. To support the growing level of external financing, they will finalize by end-2010 a comprehensive multi-year debt strategy, and will continue to strengthen their debt management, and in particular train staff to facilitate the semi-annual production of a debt sustainability analysis (DSA). The first such analysis will be completed and published by end-September 2010.

\section{Monetary and exchange rate policies}

11. The Bank of Mozambique (BM) is committed to implement prudent monetary and exchange rate policies aimed at containing inflation at single-digit on average over the medium term. These policies should help contain inflationary pressures emanating from the recent depreciation of the metical and the spillovers from higher domestic fuel prices due to the removal of fuel subsidy. In its monetary policy implementation, the BM will continue to pay close attention to the real effective exchange rate vis-àvis a broad basket of currencies. This should allow the exchange rate to adjust freely to evolving patterns of trade and financial flows while safeguarding international reserves.

12. The monetary policy transmission mechanism remains complex. In this regard, the BM will during the new PSI program (i) assess which inflation rate should be targeted and what core inflation rate should be used to assess inflationary conditions; (ii) enhance its monitoring, understanding, and capacity to project the monetary transmission mechanism; (iii) select and implement new monetary instruments to steer monetary conditions effectively; and (iv) improve its communications strategy with the public. 


\section{Structure reforms}

13. The authorities will continue with their reforms to improve the business environment to help raise Mozambique's growth potential, diversify exports, and stimulate new investment. In coordination with their development partners, they will work toward implementing a range of fast-track measures. This is expected to ease red tape, streamline the granting of business-related licenses, improve bankruptcy proceedings, and facilitate trading across borders.

14. In order to improve their statistical data compilation and dissemination, the authorities will focus on improving data quality related to the quarterly national accounts, consumer prices index, government finance statistics, and megaprojects. In the process, the authorities will request Fund's TA and advice. In particular, the National Statistics Institute (INE) will improve the calculation and the rebase of the CPI, and increase its geographical coverage. Furthermore, the authorities will ensure that INE's Strategic Plan is aligned with government's planning and budgeting cycle in order to influence policy development.

15. On PFM reforms, the authorities envisage a series of key measures in the short run comprising: (i) the implementation of SISTAFE system (e-SISTAFE) to more districts and other institutions, as well as on coverage of budget execution; (ii) the salary calculation in eSISTAFE; (iii) the integration of internal audit in e-SISTAFE system; (iv) improvement in aid management; (v) the strengthening of investment planning, limiting fiscal and quasifiscal risks, and maximizing economic benefits; (v) the improvements of the framework for public enterprises; and, (vi) the enhancement of the procurement systems.

16. Other reforms include: (i) reforming the National Institute for Social Security (INSS) to limit fiscal risks and improve governance and transparency; and, (ii) enhancing governance in the natural resources sector, and in this context the Government is committed to becoming a full member of EITI within the envisaged timeframe of two years.

17. Finally, the authorities and the Program Aid Partners (PAPs) have recently agreed on several economic and political governance issues during the last Annual Review concluded in May 2010. The authorities are committed to accelerate reforms in this area, which is also very important to sustain strategies to support growth and poverty reduction without increasing inequalities in the society.

\section{Conclusion}

18. Mozambique has an enormous potential for rapid economic growth, and the authorities' policy reforms are intended to unleash such potential. In this context, the authorities' desire to identify additional resources to finance an ambitious investment program is a major objective, but the success of this development drive will depend on an approach that combines prudent macroeconomic management with the identification of the right public investments. In addition, it is also clear to the authorities that securing additional 
financing for infrastructure investments is only part of the problem. This needs to be complemented with efforts to improve the business environment, allowing for greater flexibility in land and labor markets, and improving the logistics for trade. All of these ingredients are needed to unleash private sector initiative, and thereby ensure that the existing infrastructure, as well as the newly planned investments, can be fully utilized to generate economic activity and create wealth.

19. The authorities remain committed to accelerate the broader reform agenda, and mobilize the requisite financing without compromising the debt sustainability of the country. They are also aware that facing these challenges will require additional capacity and good governance. To that end, the authorities count on the support of both the Fund and other development partners to provide TA and enhance policy discussions in the implementation of their development programs. In this context, they request the completion of the sixth review under the PSI, the second review under the ESF, and the approval of the successor three-year PSI for the period 2010-2013. 